Szegedi Tudományegyetem

Természettudományi és Informatikai Kar

Környezettudományi Doktori Iskola

Ökológiai Tanszék

\title{
Szubmediterrán erdei hangyaközösségek \\ (Hymenoptera: Formicidae) tér- és időbeli szerveződése
}

Doktori (PhD) értekezés

Lőrinczi Gábor

témavezető:

Prof. Dr. Gallé László

professor emeritus, SZTE, Ökológiai Tanszék

Szeged

2014 


\section{Tartalomjegyzék}

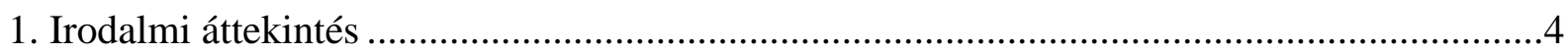

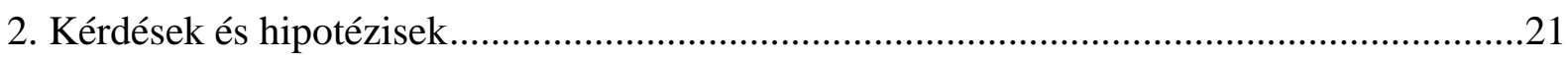

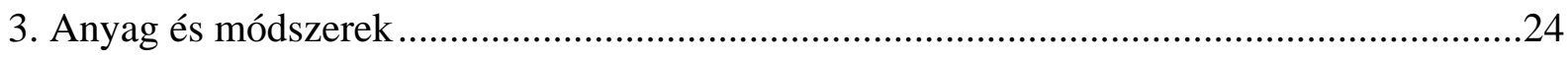

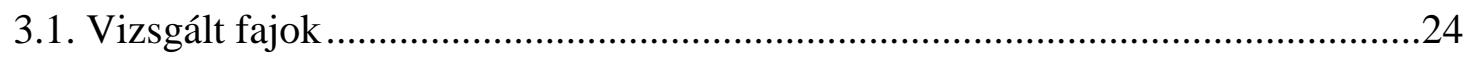

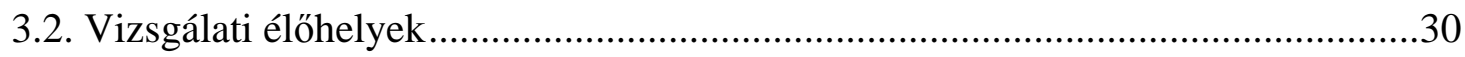

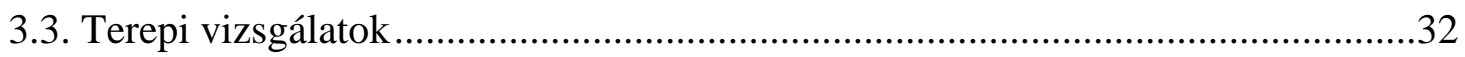

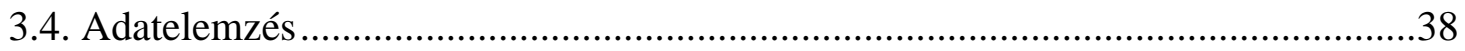

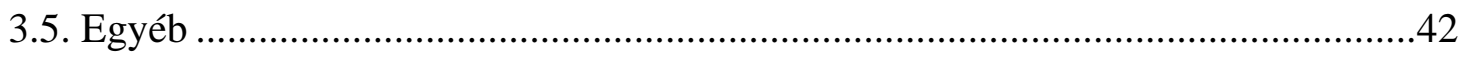

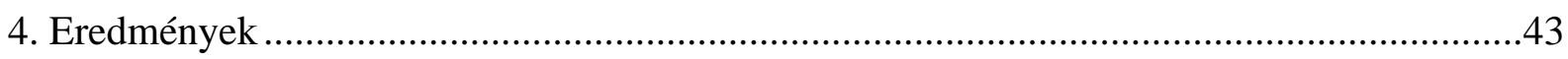

4.1. Fészkek denzitásának és diszpergáltságának tér-idő mintázata...........................43

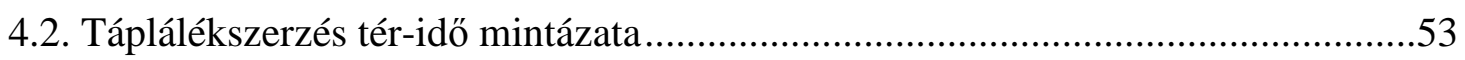

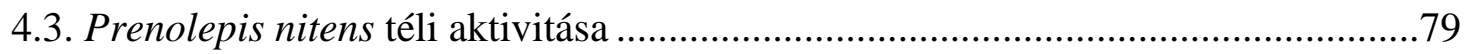

4.4. Aphaenogaster subterranea eszközhasználata ...................................................81

4.5. Aphaenogaster subterranea asszociációja recéskabócákkal..................................85

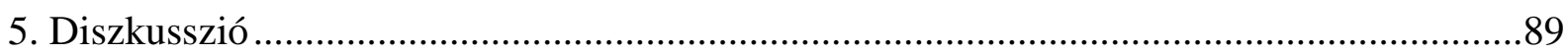

5.1. Fészkek denzitásának és diszpergáltságának tér-idő mintázata............................89

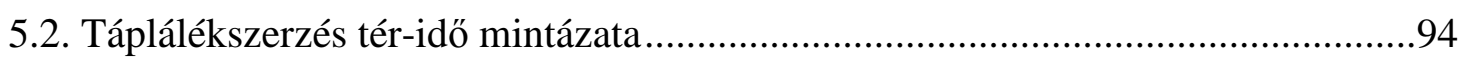

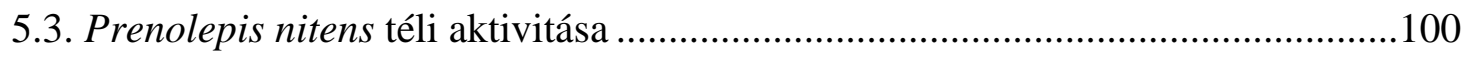

5.4. Aphaenogaster subterranea eszközhasználata ................................................103

5.5. Aphaenogaster subterranea asszociációja recéskabócákkal................................106

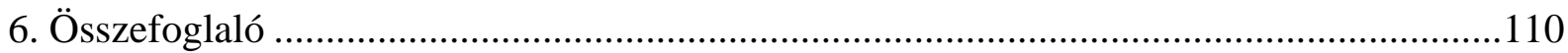

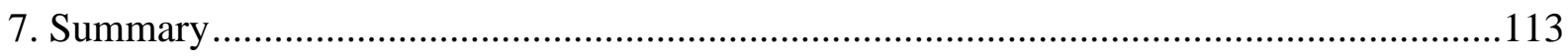

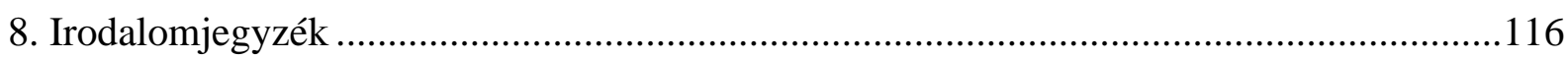

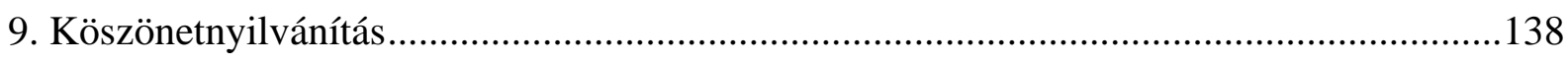

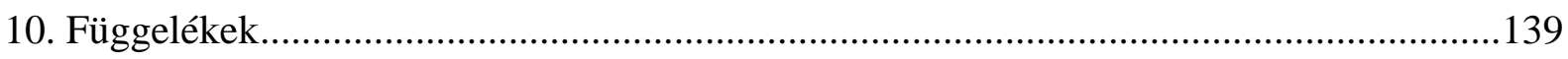

11. A dolgozat témaköréből készült publikációk jegyzéke ..................................................156

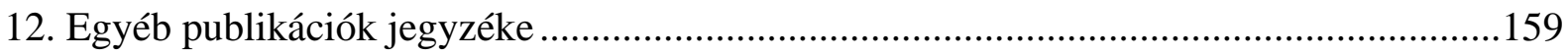


„Ti fürgén hemzsegők, föl, föl sietve, az óriás erök alkotta hegyre. Csak résröl résre fel!

Gyorsan ki és be! Nincs ott egy morzsa, mely sokat ne érne. Akármily eldugott s bármily parányi, rá kell a zegzugok között találni. A hangyálló rajok mind azt kutassák. Aranyat hozzatok, ne a salakját!"

(Goethe: Faust) 


\section{Irodalmi áttekintés}

Bevezetés

A hangyák (Hymenoptera: Formicidae) a társas rovarok egyik legfajgazdagabb és ökológiai szempontból legdiverzebb csoportját képezik (Hölldobler és Wilson 1990). Sikerük kulcsa a termeszekhez és más társas szerveződésű hártyásszárnyúakhoz hasonlóan fejlett euszociális életmódjukban rejlik, amelynek jellemzője, hogy kolóniáikban több generáció tagjai élnek együtt, utódaikat közösen, kooperatívan gondozzák és az egyedek között reproduktív funkciófelosztás van szaporodóképes ivaros alakokkal és mindenfajta más tevékenységet ellátó, az előbbiektől morfológiailag is jól elkülönülő ivartalan dolgozókkal (Gallé 2013).

A hangyák eredete egészen a kréta időszakig, azaz mintegy 120 millió éves múltra tekint vissza, bár meghatározóvá csupán a paleogén időszak során váltak (Grimaldi és Engel 2005; Wilson és Hölldobler 2005; LaPolla és mtsai. 2013). Jelenleg több mint 300 hangyagénusz közel 13 ezer faja ismert (Bolton 2014), ám tényleges diverzitásuk ennél jóval nagyobb lehet, a becslések szerint akár a 25-30 ezer fajt is meghaladhatja (Ward 2010). Noha fajszámuk az ismert rovarfajoknak kevesebb mint 2\%-át teszi ki, biomasszájuk a rovarok összbiomasszájának akár harmadát is alkothatja (Wilson 1990). Földrajzi elterjedésük igen széles, az Északi- és a Déli-sark, valamint a szárazföldtől távolabb eső óceáni szigetek kivételével csaknem mindenhol megtalálhatóak, bár legnagyobb diverzitásukat a déli félteke trópusain érik el (Hölldobler és Wilson 1990; Folgarait 1998; Dunn és mtsai. 2009).

Abundanciájuk, gyakoriságuk, fejlett társas életmódjuk és a környezetükre gyakorolt hatásuk miatt a hangyák a szárazföldi életközösségek meghatározó elemeit képezik. Nem csupán ragadozókként, növényevőkként, magterjesztőkként vagy ún. „talajmérnökökként” töltenek be fontos ökológiai szerepet (Hölldobler és Wilson 1990; Folgarait 1998), de emellett több mint 50 növénycsalád közel 500 fajával (Jolivet 1996), több ezer különböző ízeltlábú fajjal (Hölldobler és Wilson 1990), ill. számos gombával és mikroorganizmussal (Mueller és mtsai. 2005) állnak kapcsolatban, továbbá 2000-nél is több olyan ízeltlábú faj ismert mintegy 54 családból, amelyek testalkatukkal, mintázatukkal vagy viselkedésükkel mimikrizálnak hangyákat (McIver és Stonedahl 1993).

Kellően nagy fajszámuk és denzitásuk, kitüntetett jelentőségük, valamint a más csoportok tagjaitól való jó elkülönültségük, ill. relatíve egyszerű mintavételezhetőségük és elméleti érdekességük a hangyákat messzemenően alkalmassá teszi a különböző ökológiai 
(pl. közösségi szintü, biomonitoring, stb.) vizsgálatokra (Gallé 2000; Hoffman és Andersen 2003; Underwood és Fisher 2006).

\section{A kompetíció mint közösségszervezö mechanizmus}

A hangyák sajátos életmódjuk következtében számos olyan életmenet jelleggel rendelkeznek, amelyek mind a populációikon belül, mind a populációik között jelentős kompetíciót implikálnak. Euszociális életmódjuk és moduláris szerveződésük egyrészt nagyban képes tompítani a zavarás és környezeti stressz káros hatásait, így kolóniáik az alapítási szakaszt követően rendszerint nagyfokú perzisztenciát mutatnak és gyakran igen hosszú ideig elélnek (Savolainen és Vepsäläinen 1988; Hölldobler és Wilson 1990; Andersen 1991, 2008; Davidson 1998). Másfelől a hangyakolóniák az olyan szesszilis organizmusokhoz hasonlóan, mint amilyenek a növények rendszerint fix pozíciókat foglalnak el, így képesek monopolizálni a teret és az ott fellelhető készleteket, miáltal az adott élőhelyen élő más populációkra (köztük más hangyákra) is jelentős nyomást gyakorolhatnak (Andersen 1991). Harmadrészt, noha előfordulnak közöttük táplálékspecialisták, a legtöbb hangyafaj generalista ragadozó, dög- és mézharmatfogyasztó, így az egy adott élőhelyen együtt élő fajok gyakran rendelkeznek hasonló, egymással jelentős mértékben átfedő készletigényekkel (Levings és Traniello 1981; Hölldobler és Wilson 1990; Andersen 1991; Davidson 1998).

Az elmúlt évtizedekben számos vizsgálat irányult annak feltárására, hogy melyek lehetnek azok a mechanizmusok, amelyek a leginkább meghatározóak a hangyaközösségek struktúrájának kialakításában. A kompetíció ilyetén való jelentőségének bizonyítékaként elsősorban a táplálékkereső dolgozók, ill. kolóniák közötti interferencia jellegü viselkedések, valamint az egyes fajok előfordulásának tér- és/vagy időbeli mintázatának jellegzetességei szolgálnak, többek között kiemelendő a dominancia hierarchiák megléte (pl. Vepsäläinen és Pisarski 1982; Fellers 1987; Andersen 1992; Cerdá és mtsai. 1997; Bestelmeyer 2000), a territorialitás (pl. Levings és Traniello 1981; Adams 1990; Pfeiffer és Linsenmair 2001) és ennek különböző megjelenési formái, pl. az ún. „hangyamozaikok” (pl. Majer és mtsai. 1994; Delabie és mtsai. 2000), a dominancia és diverzitás kapcsolata (Andersen 1992; Parr és mtsai. 2005; Parr 2008), valamint az inváziós fajoknak a natív hangyaközösségekre gyakorolt hatása (pl. Holway és mtsai. 2002).

Noha a kompetíciót hagyományosan az egyik legfontosabb közösségszervező mechanizmusként tartják számon a hangyáknál (Hölldobler és Wilson 1990), az újabb vizsgálatok, bár szerepét továbbra is meghatározónak tekintik, a kompetitív interakciók 
kimenetelét befolyásoló további tényezők (pl. hőmérséklet, a parazitoidok jelenléte, a táplálékforrás típusa, az élőhely komplexitásának mértéke, stb.), ill. a kompetíciót potenciálisan helyettesítő más egyéb mechanizmusok (pl. sztochasztikus folyamatok) jelentőségét is hangsúlyozzák (Ribas és Schoereder 2002; Andersen 2008; Parr és Gibb 2010; Cerdá és mtsai. 2013).

\section{Dominancia hierarchiák}

Bizonyos releváns életmódbeli tulajdonságaik (pl. táplálkozási stratégiájuk, kommunikációs készségük, agresszivitásuk mértékének, stb.) különbözősége miatt az egyes hangyafajok jellemzően dominancia hierarchiákba szerveződnek a hierarchia csúcsát elfoglaló domináns fajokkal és a rangsor alján elhelyezkedő ún. szubordinált fajokkal (pl. Vepsäläinen és Pisarski 1982; Fellers 1987; Savolainen és Vepsäläinen 1988, 1989; Vepsäläinen és Savolainen 1990; Andersen 1992; Andersen és Patel 1994; Majer és mtsai. 1994; Morrison 1996; Cerdá és mtsai. 1997, 1998a; Bestelmeyer 2000; LeBrun és mtsai. 2007; Wiescher és mtsai. 2011; Cerdá és mtsai. 2012; Czechowski és mtsai. 2013). Közösségtől függően a dominanciaviszonyok az intranzitív hálózatoktól ( $A$ faj domináns a $B$ felett, $B$ a $C$ felett, $C$ pedig az $A$ felett) a tranzitív, lineáris dominancia hierarchiákig ( $A$ faj domináns $B$ felett, $A$ és $B$ a $C$ felett, stb.) igen széles skálán változhatnak (LeBrun 2005).

A hierarchia csúcsán álló domináns fajok gyakran a készletek aránytalanul nagy részét irányíthatják, ezáltal direkt vagy indirekt módon jelentős mértékben korlátozva a szubordinált fajok táplálkozási és/vagy fészkelési sikerét, mely utóbbiak így gyakorta a kedvezőtlenebb, stresszesebb körülmények közé kényszerülnek (pl. Fellers 1987; Savolainen és Vepsäläinen 1988, 1989; Vepsäläinen és Savolainen 1990; Andersen 1992; Andersen és Patel 1994; Majer és mtsai. 1994; Morrison 1996; Cerdá és mtsai. 1997; Bestelmeyer 2000; Sanders és Gordon 2000, 2003; Palmer 2003). Főként kisebb térléptékben ennek következtében a fajgazdagság és a kompetitív dominancia közötti kapcsolat jellemzően unimodális, azaz a domináns fajok abundanciájának megnövekedése, és így a kompetíciós nyomás fokozódása egy adott ponton túl többnyire a lokális diverzitás csökkenését okozza (Andersen 1992; Parr és mtsai. 2005; Parr 2008).

Hangyák esetében a táplálkozási viselkedés alapján történő első klasszifikáció Wilson (1971) nevéhez köthető, aki három kategória-típust különböztetett meg: (1) a táplálékforrást igen hamar, még jóval a többi faj megjelenése előtt felfedezni és kiaknázni képes, tehát az exploitatív kompetícióban sikeresebb, de egyébként félénk opportunistákat, (2) a 
táplálékforrást relatíve hosszabb idő alatt felfedező, de oda nagyszámú dolgozót rekrutálni képes, és azt más fajoktól agresszívan védelmező, azaz az interferencia kompetícióban eredményesebb ún. „exstirpálókat”, valamint (3) a domináns fajok által monopolizált táplálékforráson kis számban megjelenő, arról észrevétlenül táplálékot elcsenni igyekvő ún. „,beférkőzőket”. Szintén háromszintű, a kolóniák szociális szerveződésének más egyéb sajátosságait is figyelembe vevő hierarchiát képvisel Vepsäläinen és Pisarski (1982) klasszifikációja, megkülönböztetve (1) a nagy kolóniával rendelkező, mind a fészküket, mind a táplálkozási területüket agresszívan védelmezö, a táplálékforrást nagy egyedszámmal monopolizálni képes domináns (vagy territoriális) fajokat (pl. Formica s. str. spp., Oecophylla spp., Iridomyrmex spp.), (2) a közepes kolóniaméretü, a fészkükön kívül a táplálékforrást is agresszívan védelmező, azon viszonylag nagyszámban megjelenő szubdomináns (vagy ún. „ütköző”) fajokat (pl. Lasius spp., Pheidole spp., Tetramorium spp.), valamint (3) a kis kolóniájú, legfeljebb a fészküket védelmező, a táplálékforráson kis egyedszámban megjelenő, félénk, a más fajokkal történő interakciót elkerülö ún. szubmisszív fajokat (pl. Serviformica spp., Plagiolepis spp., Temnothorax spp.). Gallé (2000), főleg spanyolországi mediterrán hangyaközösségek vizsgálatára alkalmazott ötös felosztásában a fenti három kategória mellett két újabb szint is helyet kap, ezek egyikét a táplálékforrást a domináns fajokhoz hasonlóan monopolizálni képes, ám azt kevésbé hatékonyan kiaknázó, több jellegükben inkább a hierarchia alján lévőkhöz közelítő Camponotus-fajok, míg a másikat az extrém magas hőmérsékleteken is aktív, így más fajoktól aktivitási ritmusukban nagyban elkülönülő, de egyébként a szubmisszívekhez közel álló ún. termotoleráns fajok (pl. Cataglyphis spp.) képviselik.

Maga a dominancia, bár általánosságban a különböző készletek (pl. táplálékforrás vagy fészkelőhely) feletti irányítást jelöli, természetesen többféle módon is megnyilvánulhat, így beszélhetünk viselkedésbeli (fölény az agresszív interakciók során), számbeli (nagy abundancia és/vagy gyakori előfordulás), valamint ökológiai ${ }^{1}$ (nagy felfedezési siker az általános előforduláshoz viszonyítva) dominanciáról is (Parr és Gibb 2010; Cerdá és mtsai. 2013). Ennek megfelelően számos taxon vagy funkcionális csoport képviselői minősülhetnek dominánsnak (Hölldobler és Wilson 1990), jóllehet abundanciájuk, nagyfokú agresszivitásuk és territorialitásuk miatt hagyományosan a fent említett háromszintű hierarchia csúcsán álló fajokat, úgymint az ún. domináns Dolichoderinae funkcionális csoport képviselöit, az

\footnotetext{
${ }^{1}$ A fenti közkeletüen használt definíciótól eltérően az ökológiai dominancia fogalmát a továbbiakban a számbeli és a viselkedésbeli dominancia kombinációjaként használom Davidson (1998) eredeti meghatározásának megfelelően.
} 
Oecophylla-génusz tagjait vagy a Formica rufa- és exsecta-csoportok fajait tekintik dominánsnak (Savolainen és Vepsäläinen 1988, 1989; Andersen 1995, 1997, 2010; Arnan és mtsai. 2011). Számos hangyaközösség esetében azonban, ahonnét a territoriális fajok hiányoznak a hierarchia alsóbb szintjén elhelyezkedő szubdomináns fajok töltenek be hasonló szerepet, nagyban strukturálva az adott közösséget a különböző kompetitív mechanizmusok révén (Lynch és mtsai. 1980; Fellers 1987, 1989; Cerdá és mtsai. 1997; Lessard és mtsai. 2009; Stukalyuk és Radchenko 2011; Stuble és mtsai. 2013). Mindezek mellett az egyes fajok között kialakuló hierarchiák gyakran erősen kontextusfüggőek lehetnek, számos tényező, kezdve a kolóniák méretétől és fejlődési stádiumától (pl. Savolainen és Vepsäläinen 1988; Palmer 2004) a táplálékkereső dolgozók egyedszámán át (pl. Fellers 1987; Markó és Czechowski 2004) a hőmérsékletig (pl. Cerdá és mtsai. 1997) vagy a parazitoidok jelenlétéig (pl. LeBrun 2005; LeBrun és Feener 2007) nagyban befolyásolhatja a dominancia mértékét, és így ennek megfelelően az adott faj pozícióját a hierarchiában.

\section{Koegzisztencia}

Amennyiben a populációk közötti kompetíció valóban jelentős szerepet játszik a hangyaközösségek szerveződésében, felvetődik annak kérdése, hogy milyen ún. kompenzáló mechanizmusok teszik lehetővé az egymással versengő fajok tartós együttélését. Ezek hiányában ugyanis a lineáris dominancia hierarchiák meglétének egyenes következménye lenne, hogy a rangsor legelején álló csúcskompetítorok az összes többi fajt „,kikompetálják”, holott a természetes, inváziós fajoktól mentes közösségekben többnyire számos faj koegzisztál (LeBrun 2005; Feener és mtsai. 2008), mi több a rendkívüli fajgazdagság olykor nagyfokú viselkedésbeli dominanciával is párosulhat (Andersen 1995).

Csereviszonyok (Trade-offok)

A különböző életmenet jellegek közötti inverz kölcsönhatásokat, azaz az ún. csereviszonyokat vagy trade-offokat a leggyakoribb olyan mechanizmusokként tartják számon, amelyek elősegíthetik a szüntopikus fajok együttélését, különösen kis térléptékben (Kneitel és Chase 2004). A hangyaközösségek esetében a különböző csereviszonyok hatókörüket illetően nagymértékben különböznek egymástól, kapcsolatban állhatnak többek között a készlethasználattal (pl. Fellers 1987; Davidson 1998), a kolonizációs képességgel (Stanton és mtsai. 2002), a természetes ellenségekre való érzékenységgel (pl. LeBrun és 
Feener 2007) vagy a hőmérsékleti stressztoleranciával (pl. Cerdá és mtsai. 1997; Bestelmeyer 2000).

Hangyáknál az egyik leggyakrabban citált ilyen csereviszony az ún. dominanciaforrásfelfedezés trade-off, amely szerint a kevésbé agresszív, szubordinált fajok képviselői azok, amelyek a leggyorsabban, legnagyobb hatékonysággal képesek felfedezni és kiaknázni a különféle táplálékforrásokat, így elkerülvén az ütközést az agresszívabb, a táplálékforrást monopolizálni képes, ám azt relatíve hosszabb idő alatt felfedező domináns fajok egyedeivel (Fellers 1987; Davidson 1998). A jobb felfedező képességgel rendelkező szubordinált fajok jelenléte emiatt bizonyos esetekben a táplálékforrás megtalálásában segítheti a domináns kompetítorokat, amelyek így egy bizonyos egyedsürüségig megtürhetik az alárendeltebb faj képviselöit maguk körül (Reznikova 1982; Savolainen és Vepsäläinen 1988). Mint arra azonban Davidson (1998) rámutatott, bizonyos fajok képesek úgymond „megszegni” ezt a csereviszonyt, ha stabil, kiadós táplálékforrás (pl. mézharmat) áll rendelkezésükre (Davidson 1998; Palmer 2003) vagy természetes parazitoidjaik nem korlátozzák őket (LeBrun és Feener 2007). Tipikusan jellemző lehet ez az ökológiailag domináns, territoriális, poligyn kolóniájú, polidómuszos fajokra, köztük az olyan széles körben elterjedt, neotrópusokról behurcolt inváziós fajokra, mint a Linepithema humile vagy a Solenopsis invicta (Human és Gordon 1996; Davidson 1998; Holway 1999; Feener 2000; LeBrun és mtsai. 2007). Emellett a dominancia-forrásfelfedezés trade-off erősen kontextusfüggő, lévén mind a felfedező képességet, mind a dominanciaviszonyokat számos tényező befolyásolhatja, kezdve a hőmérséklettől a parazitoidok jelenlétéig (ld. lentebb), sőt egyes esetekben a kettő kapcsolata a teljes közösségre nézve akár pozitív is lehet (Santini és mtsai. 2007; Parr és Gibb 2012). Bár számos korábbi vizsgálat kimutatta ezen csereviszony jelentőségét, a legújabb kutatások fényében már sokkal inkább tekinthető kivételnek, mint szabálynak (Parr és Gibb 2012).

Egy másik jellemző, az egymással kompetáló fajok koegzisztenciáját potenciálisan elősegítő csereviszony az ún. dominancia-hőmérsékleti tolerancia trade-off, amelynek értelmében a szubordinált fajok a domináns fajokénál jóval nagyobb hőmérsékleti toleranciával rendelkeznek, így gyakran akár az extrém magas vagy szuboptimálisan alacsony hőmérsékleteken is képesek aktívan táplálékot gyüjteni, elkerülvén ezáltal az utóbbi fajok képviselőivel való találkozást (Cerdá és mtsai. 1997, 1998b; Bestelmeyer 2000; Lessard és mtsai. 2009). Ezen csereviszony azonban erősen élőhelyfüggő, kialakulására leginkább a nyíltabb, száraz élőhelyeken lehet számítani, ahol jelentős a hőmérséklet-ingadozás (Wiescher és mtsai. 2011; Cerdá és mtsai. 2013), míg ezzel szemben a kiegyenlítettebb hőmérsékleti viszonyokkal rendelkező fás élőhelyeken a dominancia és a hőmérsékleti tolerancia közötti 
kapcsolat akár pozitív is lehet (Santini és mtsai. 2007). A kevésbé hőtürő domináns fajok ennek megfelelően nagyban kihasználhatják a tér heterogenitását (pl. a növényzet vagy felhők által vetett árnyékos foltokat), így a forróbb napokon is kiterjeszthetik aktvitásukat, ezáltal jelentős kompetíciós nyomást kifejtve a szubordinált fajokra (Bestelmeyer 1997; Cros és mtsai. 1997).

A fentiek mellett a dominancia csereviszonyban állhat (1) a kolonizációs képességgel, amennyiben a szubordinált fajok királynői a domináns fajokéinál hatékonyabban képesek az alkalmas fészkelőhelyeket elfoglalni (Stanton és mtsai. 2002), (2) a természetes ellenségekre való érzékenységgel, amely a szubordinált fajokat juttathatja előnyhöz a gazdaspecifikus parazitoidok támadásának kitett domináns fajokkal szemben (Feener 2000; LeBrun 2005; LeBrun és Feener 2007; Feener és mtsai. 2008), valamint (3) a táplálkozási hatékonysággal, ha az agresszív viselkedés a táplálkozásra fordítható időt, és így a fogyasztást jelentősen csökkenti (Gallé 2000). Továbbá, nagyobb térléptékben a növénytársulásokhoz hasonlóan a hangyaközösségek esetében is egyfajta csereviszony alakulhat ki a zavarástürés, a stressztolerancia és a kompetíciós képesség között, azaz míg a hierarchia csúcsán álló domináns fajok legnagyobb abundanciájukat és diverzitásukat azokon az élőhelyeken érik el, ahol a legkedvezőbbek a körülmények, addig a gyenge kompetíciós képességgel rendelkező szubordinált fajok a zavart vagy stresszes élőhelyeken töltenek be meghatározó szerepet, ahonnét az előbbiek nagyrészt vagy teljesen hiányoznak (Andersen 1995).

\section{Térbeli elkülönülés}

A különböző csereviszonyok mellett a koegzisztenciát segítheti elő a térben való elkülönülés is azáltal, hogy nagymértékben csökkentheti az egyes, konspecifikus vagy heterospecifikus kolóniák tagjai közötti találkozások gyakoriságát. Ilyen térbeli szegregáció jelentkezhet pl. táplálékkereséskor, ha az egyes kolóniák táplálkozási területei nem vagy csak kismértékben fednek át, vagy a táplálékkeresést különböző vertikális szinteken végzik (Gallé 1979, 1986; Harrison és Gentry 1981; Ryti és Case 1986; Savolainen és Vepsäläinen 1989; Albrecht és Gotelli 2001; Wittman és mtsai. 2010; Arnan és mtsai. 2011; Pekas és mtsai. 2011; Stukalyuk és Radchenko 2011; Cerdá és mtsai. 2012).

A térbeli elkülönülés különösen kifejezett lehet a domináns, a fészkük mellett a táplálkozási területüket is agresszívan védelmező territoriális fajok kolóniái között (Levings és Traniello 1981; Savolainen és Vepsäläinen 1988; Adams 1990; Morrison 1996; Pfeiffer és Linsenmair 2001; Czechowski és mtsai. 2013). A trópusok és a mediterrán régió arboreális, 
ill. avarlakó hangyaközösségei esetében a territoriális fajok térbeli szegregációja jellemzően ún. „hangyamozaikok” kialakulásához vezethet, amelyeket az egymással át nem fedő territóriummal rendelkező, a készleteket nagymértékben monopolizáló domináns fajok és az ezekkel különböző mértékben asszociáló szubordinált fajok együttesei hoznak létre (Room 1971; Majer 1976; Adams 1994; Majer és mtsai. 1994; Delabie és mtsai. 2000; Blüthgen és mtsai. 2004; Pekas és mtsai. 2011). Ezen „mozaikok” kialakulásában ugyanakkor az interspecifikus kompetíción túl más tényezők (pl. az élőhely heterogenitása, sztochasztikus folyamatok, stb.) is közrejátszhatnak, sőt, bizonyos vizsgálatok alapján az egyes fajok együttes előfordulási mintázatai nem is mindig különböznek feltétlenül a véletlenszerütől (Floren és Linsenmair 2000; Ribas és Schoereder 2002; Sanders és mtsai. 2007).

\section{Fészkek términtázata}

A fentiek mellett a térbeli elkülönülést ugyancsak jól példázza a talajszinten lakó hangyafajok fészkeire igen gyakran jellemző szegregált (egyenletes) términtázat, amelynek hátterében a legelfogadottabb magyarázat szerint a kolóniák közötti kompetíció áll (pl. Gallé 1975; Bernstein és Gobbel 1979; Harrison és Gentry 1981; Levings és Traniello 1981; Levings és Franks 1982; Ryti és Case 1984, 1986; Cushman és mtsai. 1988; Schooley és Wiens 2003; Vasconcellos és mtsai. 2004). A fészkek egyenletes términtázata nagyban csökkentheti a táplálkozási területek, ill. a territóriumok közötti átfedés nagyságát, ezáltal minimalizálva a kompetíció nagyságát, különösen, ha a fészkek denzitása nagy (Bernstein és Gobbel 1979; Harrison és Gentry 1981; Levings és Franks 1982; Ryti és Case 1984, 1986; Cushman és mtsai. 1988). Ilyen típusú términtázatot eredményezhet (1) a kolóniaalapító nőstények által preferált fészkelőhelyek szabályos térbeli eloszlása, (2) a már érett kolóniák területén kolóniaalapítást kísérlő nőstények predációja vagy kizárása, (3) a kisebb és/vagy fiatalabb kolóniák idősebb kolóniák által történő elpusztítása vagy elüzése, (4) a fiatalabb kolóniák mortalitásának megnövekedése a készletek szomszédos kolóniák általi „kimerítése” révén, (5) a maturus kolóniák közötti territoriális harcok, vagy (6) az egyes kolóniák elköltözése az idegen kolóniák fészkeinek közeléből (Wilson 1971; Rockwood 1973; Levings és Traniello 1981; Levings és Franks 1982; Hölldobler és Wilson 1990; Ryti és Case 1986, 1992; Wiernasz és Cole 1995; Franks és mtsai. 2007; McGlynn 2012).

Levings és Traniello (1981) konceptuális modellje szerint egy több hangyafajból álló közösség esetén a fészkek términtázatát várhatóan az egyes fajok ökológiai tulajdonságai fogják meghatározni, különös tekintettel az intra- és interspecifikus kompetitív interakciók 
relatív erősségére. Ha több, azonos ökológiai igényü és hasonló méretü táplálkozási területtel rendelkező faj populációja fordul elő egy adott élőhelyen, akkor az intra- és interspecifikus kompetíció egyformán erős lesz, így (1) az összes fészek egyenletes términtázatot fog mutatni, (2) az egyes fajok fészkeinek térbeli eloszlása ettől véletlenszerübb lesz, (3) a legközelebbi fészekszomszédok identitása ugyancsak véletlenszerü lesz (azaz ezek egyforma eséllyel lehetnek konspecifikus vagy heterospecifikus fészekszomszédok), valamint (4) interspecifikusan a fészektávolságok kis, míg intraspecifikusan a fészektávolságok nagy varianciája lesz jellemző. Másfelől viszont, ha a táplálkozási területek nagysága megegyezik, ám az egyes fajok ökológiai igényei eltérőek, akkor az intraspecifikus kompetíció lesz a jelentősebb szervező erő, és ebben az esetben (1) mind az összes fészek, mind az egyes fajok fészkei egyenletes térbeli eloszlást fognak mutatni, (2) a legközelebbi fészekszomszédok rendre a más fajhoz tartozó kolóniák fészkei lesznek, valamint (3) mind intra-, mind interspecifikusan a fészektávolságok kis varianciája lesz jellemző.

A kompetíció mellett ugyanakkor más tényezők is fontos szerepet játszhatnak a fészektérmintázat kialakításában, ilyen többek között a kolóniák mérete és kora (Ryti és Case 1986; Cushman és mtsai. 1988; Adams és Tschinkel 1995; Wiernasz és Cole 1995), a kolóniák/fészkek denzitása (Waloff és Blackith 1962; Gallé 1975, 1980; Cushman és mtsai. 1988; Ryti 1991; Ryti és Case 1992), a diszperzió módja (ti. sarjadzással vagy ivarosok röptetésével) (Tanner és Keller 2012), a táplálékszerző-stratégia típusa (Hölldobler 1976; Warburg és Steinberger 1997) vagy térléptéktől függően az olyan speciális környezeti tényezők, mint pl. a besugárzás mértéke, kitettség, talajmintázat, talajnedvesség, a vegetáció jellege, a szegélyhatás mértéke, topográfiai viszonyok, stb. (Waloff és Blackith 1962; Sudd és mtsai. 1977; Bernstein és Gobbel 1979; Doncaster 1981; Cushman és mtsai. 1988; Crist és Wiens 1996; Dugas 2001). Ryti és Case (1992) szimulációs modellje szerint a fészkek términtázatát szintén nem csupán az intra- és interspecifikus kompetíció befolyásolja erőteljesen, hanem az egyes kolóniák „,születési” és „halálozási” rátája is, ennek megfelelően a fészkek szegregált diszpergáltsága sokkal inkább az idősebb kolóniák szomszédságában fészkelő fiatal kolóniák megnövekvő mortalitásának a következménye lesz, mintsem a már érett kolóniák közötti direkt kompetícióé.

Noha az egyenletes térbeli eloszlás a leggyakoribb, más términtázat-típusokat, így aggregált (Elmes 1974; Sudd és mtsai. 1977; Doncaster 1981; Herbers 1985, 1989, 2011; Petrov és Gallé 1986; Gallé és mtsai. 1994; Dugas 2001; Soares és Schoereder 2001; Albuquerque és mtsai. 2005; Lőrinczi 2011) és véletlenszerü diszpergáltságot (Elmes 1974; Gallé 1991; Warburg és Steinberger 1997; Fernández-Escudero és Tinaut 1999; Sanders és 
Gordon 2000; Lőrinczi 2011) is leírtak már hangyafészkek esetében. A fészkek aggregációja egyrészt következménye lehet az élőhely foltozottságának, de származhat az egyes kolóniák több fészekre való fragmentálódásából (polidómia), a különböző egyéb interspecifikus interakciókból (pl. predáció, mutualizmus, ill. a szociálparazitizmus különféle formái), valamint az intenzív intraspecifikus kompetícióból, amely egy adott faj kolóniáit a konspecifikus kolóniák fészkeitől távolabb, a heterospecifikus kolóniák fészkeinek közelébe kényszerítheti (Ryti és Case 1984; Herbers 1985, 1989, 2011; Hölldobler és Wilson 1990; Cole és mtsai. 2001; Soares és Schoereder 2001). Ezzel szemben a véletlenszerü diszpergáltság gyenge kölcsönhatásokat feltételez mind az egyes populációk, mind pedig a populációk és környezetük között, habár jellemző lehet akkor is, ha az adott élöhelyen a kolóniák denzitása alacsony (Waloff és Blackith 1962; Cushman és mtsai. 1988), pl. a szukcesszió bizonyos stádiumaiban (Gallé 1991; Gallé és mtsai. 1998), vagy ha a kolóniák mortalitása térben random (Adams és Tschinkel 1995), ill. az adott élőhelyet az alkalmas fészkelőhelyek bősége jellemzi (Fernández-Escudero és Tinaut 1999).

Bár a hangyafészkek egyenletes diszpergáltságának kialakításában kitüntetett szereppel bír, maga a kompetíció is létrehozhat más típusú términtázatot (Ryti 1991; Ryti és Case 1992; Adams és Tschinkel 1995; Sanders és Gordon 2000). Ennek és a fentieknek megfelelően a fészkek egyenletes térbeli eloszlása önmagában véve még nem tekinthető a kompetíció egyértelmü bizonyítékaként (Ryti és Case 1992; Adams és Tschinkel 1995; Parr és Gibb 2010; McGlynn 2012), jóllehet ennek fordítottja is igaz, azaz a szegregáltság hiánya sem jelenti feltétlenül azt, hogy a kompetíció nem lényeges szervező erő az adott közösségben (Schooley és Wiens 2003).

\section{Időbeli elkülönülés}

A térbeli szegregációhoz hasonlóan a szüntopikus hangyafajok koegzisztenciáját segítheti elő az időbeli elkülönülés is, amely leginkább az eltérő napi- és/vagy évszakos aktivitási ritmusban nyilvánul meg, és amely a releváns ökostátusz dimenziókra vetítve nicheszegregációként is értelmezhető (Hunt 1974; Gallé 1979, 1986; Lynch és mtsai. 1980; Fellers 1987, 1989; Vepsäläinen és Savolainen 1990; Cerdá és mtsai. 1997, 1998a; Cros és mtsai. 1997; Albrecht és Gotelli 2001; Santini és mtsai. 2007; Stukalyuk és Radchenko 2011; Stuble és mtsai. 2013). Ez nagyban csökkentheti az idegen kolóniák tagjai közötti agonisztikus interakcióik intenzitását, ezáltal lehetővé téve a készletek hatékonyabb felosztását. 
A hangyák időbeli aktivitási mintázatát meghatározó környezeti tényezők közül talán az egyik legfontosabb a hőmérséklet (Hölldobler és Wilson 1990), különösen azokon az élöhelyeken, amelyeket szélsőséges klimatikus viszonyok (pl. szárazság, nagy hőmérsékletingadozás, stb.) jellemeznek (Cerdá és mtsai. 1997, 1998a, 1998b; Cros és mtsai. 1997; Delsinne és mtsai. 2007). Kistestü, poikiloterm állatok lévén a hangyák különösen érzékenyek mind a túlságosan magas, mind a túlságosan alacsony hőmérsékletre, így többségük jellemzően a $10{ }^{\circ} \mathrm{C}$ és $45^{\circ} \mathrm{C}$ közötti hőmérsékleti tartományban mutat aktivitást (Bernstein 1979; Hölldobler és Wilson 1990). Az extrém meleg- (termo-) és hidegkedvelő (kriofil) fajok kivételével bármely ezen preferendumon kívül eső hőmérséklet a legtöbb hangya számára már komoly stresszforrásnak minősül, mivel megközelítheti vagy akár meg is haladhatja ezen fajok kritikus hőmérsékleti türéshatárát (Kay és Whitford 1978; Cerdá és mtsai. 1998b).

Mindazonáltal a hangyaközösségek tagjai többnyire nagymértékben különböznek hőmérsékleti preferenciájuk tekintetében, így gyakran a hőmérséklet-tartomány mentén, akár napszaktól függetlenül is jelentős mértékü szegregáció figyelhető meg közöttük (Lynch és mtsai. 1980; Vepsäläinen és Savolainen 1990; Bestelmeyer 1997, 2000; Cerdá és mtsai. 1997, 1998a, 1998b; Cros és mtsai. 1997; Markó és Czechowski 2004; Lessard és mtsai. 2009; Wittman és mtsai. 2010; Wiescher és mtsai. 2011). Az erős interspecifikus kompetíció következtében bizonyos élőhelyeken a szubordinált fajok jellemzően a domináns fajokénál jóval nagyobb hőmérsékleti toleranciával rendelkeznek, így aktivitásukat az extrém magas vagy szuboptimálisan alacsony hőmérsékleteken is megőrzik, amely a fentebb már tárgyalt dominancia-hőmérsékleti tolerancia trade-off kialakulásához vezethet (Cerdá és mtsai. 1997, 2013; Bestelmeyer 2000; Lessard és mtsai. 2009; Wiescher és mtsai. 2011). Az egyes fajok hőmérsékleti tartomány szerinti elkülönülésének jelentőségét példázzák azok az inváziónak kitett közösségek is, amelyek esetében a natív hangyafajok nagyfokú hő- vagy éppen hidegtürő képességük révén képesek rezisztensek maradni, és így koegzisztálni az ökológiailag domináns, ám a hőmérséklet szempontjából érzékenyebb inváziós fajokkal (Holway és mtsai. 2002; Thomas és Holway 2005).

A szubordinált hangyafajok olykor jellemző nagyfokú stressztoleranciája ugyanakkor nem csupán az erős kompetíciós nyomás (Andersen 1995; Bestelmeyer 1997), hanem a szélsőséges klimatikus viszonyokhoz való természetes adaptáció eredményeként is kialakulhatott (Fellers 1989; Bestelmeyer 1997; Cerdá és mtsai. 1998b). Különösen igaz lehet ez a szárazabb, nagy hőmérséklet-ingadozású élőhelyeken, ahol az egyes hangyafajok aktivitási mintázatának kialakításában a hőmérséklet szerepe jóval inkább meghatározónak 
tünik a különböző biotikus interakciókénál (Cerdá és mtsai. 1998a; Delsinne és mtsai. 2007; Wittman és mtsai. 2010).

\section{Egyéb befolyásoló tényezők}

Az eddig tárgyaltakon kívül (hőmérséklet, a parazitoidok jelenléte, stb.) számos más tényező is nagyban meghatározhatja a dominancia mértékét, ill. befolyásolhatja az egyes fajok felfedező képességét, ilyen pl. az élőhely komplexitásának, strukturáltságának mértéke (Gibb 2005; Sarty és mtsai. 2006; Luque és López 2007; Gibb és Parr 2010; Parr és Gibb 2012), a táplálékkészletek térbeli eloszlása (Palmer 2003; Lester és mtsai. 2010) vagy a táplálékforrás mérete, típusa és/vagy hozzáférhetősége (Cerdá és mtsai. 1998c; Sanders és Gordon 2003; Gibb 2005; LeBrun 2005).

A koegzisztenciát elősegítendő, Andersen (2008) szerint a készletek tér- és/vagy időbeli felosztása, ill. a kompetitív interakciók kimenetelét befolyásoló tényezők mellett fontos szerepe lehet a kolónialapítás kezdeti fázisában ható folyamatoknak (pl. a fiatal királynők predációjának), valamint a domináns fajok kis térléptékben való foltozott előfordulásának is, amely lehetővé teszi a szubordinált fajok kis denzitású jelenlétét az így kialakult „lékekben”. A domináns fajok ráadásul azáltal, hogy többnyire erős negatív hatást gyakorolnak a szubdomináns fajokra, közvetett módon a hierarchia legalsó szintjein álló szubmisszív fajoknak kedvezhetnek, amelyek így mintegy felszabadulhatnak az előbbiek kompetíciós nyomása alól (Rosengren 1986; Savolainen és Vepsäläinen 1988, 1989; Gallé és mtsai. 1998; Arnan és mtsai. 2011).

A fentiekben tárgyalt, agresszióval társult viselkedésformákon kívül külön figyelmet érdemelnek más egyéb, a kompetíció szempontjából releváns viselkedésbeli mechanizmusok is. Ilyen pl. az eszközhasználat, amely nagyban megnövelheti az eszközhasználó faj kompetíciós sikerét, valamit a növénytetvekkel és kabócákkal való trofobiotikus kapcsolat, amely nem csupán viselkedésbeli változásokat indukálhat a hangyagazdában, hanem azáltal, hogy nagyban hozzájárulhat az ökológiailag domináns fajok sikeréhez, indirekt módon a teljes közösség szerveződését is jelentős mértékben meghatározhatja.

\section{Eszközhasználat}

Az eszközhasználat St. Amant és Horton (2008) definíciója szerint valamely szabadon manipulálható, külső tárgy (= eszköz) irányított használata (1) egy másik, élő- vagy élettelen 
objektum fizikai tulajdonságának (pl. pozíciójának) dinamikus kölcsönhatás révén történő megváltoztatására, vagy (2) az eszközhasználó és környezete közötti információáramlás közvetítésére. Bár az eszközhasználat legváltozatosabb formái a verébalakúak (Passeriformes) és a főemlősök (Primates) rendjének képviselőire jellemzőek, előfordulása az állatvilágban igen széles körü, eddig összesen három törzs nyolc osztályában írtak le ilyesfajta viselkedésformákat (Mollusca: Gastropoda, Cephalopoda; Arthropoda: Malacostraca, Arachnida, Insecta; Chordata: Actinopterygii, Aves, Mammalia) (Bentley-Condit és Smith 2009).

Hangyáknál az eszközhasználat egyik legismertebb formája a szövőhangyáknál, az Oecophylla-, ill. a Polyrhachis- és Camponotus-génuszok arboreális képviselőinél fordul elő, amelyek levélfészkeiket a saját lárváik által termelt selyemfonálból szövik össze, miközben a dolgozók a lárvákat rágóik között tartják (Hölldobler és Wilson 1990). Más hangyafajok, mint pl. a Dorymyrmex bicolor vagy az Aphaenogaster cockerelli köveket használnak fel, és ezek segítségével torlaszolják el kompetítoraik fészekbejáratát (Möglich és Alpert 1979; Barton és mtsai. 2002). Hasonló viselkedést írt le Lin (1964-65) a Tetramorium caespitum (feltehetően Tetramorium sp. E, ld. Steiner és mtsai. 2008) esetében, amelynek dolgozói a megfigyelések alatt homokszemcséket felhasználva dugaszolták el egy karcsúméh, a Lasioglossum zephyrum (Halictidae) földalatti fészekbe vezető járatát.

Az eszközhasználat harmadik formája hangyáknál, amikor a táplálékkereső dolgozók a (fél)folyékony jellegü táplálék elszállításához különböző anyagokat (pl. talajszemcséket, levéldarabokat, stb.) használnak fel úgy, hogy ezeket a táplálékra helyezik, majd az így impregnált „eszközöket” szállítják vissza a fészkükbe. Ez a fajta viselkedés tipikusan az Aphaenogaster-fajokra jellemző, és eddig a génusz nyolc faja esetében írtak le hasonlót (Fellers és Fellers 1976; Tanaka és Ono 1978; Fowler 1982; McDonald 1984; Agbogba 1985; Cerdá és mtsai. 1988; Banschbach és mtsai. 2006), de előfordul a Pogonomyrmex badiusnál (Morrill 1972) és a S. invictánál is (Barber és mtsai. 1989). Az Aphaenogaster-fajok esetében az eszközhasználat ezen formája egyrészt hatékonyabb táplálékszállítást tesz lehetővé, ugyanis ennek segítségével a dolgozók jóval nagyobb mennyiségű táplálékot tudnak elszállítani, mint azt egyébként tehetnék, ráadásul ezáltal a táplálékforrásról más fajok képviselőit agresszív módon kizáró domináns fajokkal való ütközés is elkerülhetővé válik számukra (Fellers és Fellers 1976). 
A hangyák és a különböző mézharmattermelő hemipterák között létrejövő mutualista kapcsolat egy igen széles körben ismert és gazdag irodalommal rendelkező témát képvisel. Ezen interakciók során a hangyák az elsősorban különféle cukrokban gazdag mézharmatért „cserébe” védelmet és más egyéb „szolgáltatásokat” biztosítanak trofobionta partnereik számára (Buckley 1987; Hölldobler és Wilson 1990; Delabie 2001; Stadler és Dixon 2005).

A hangyagénuszok közel 41\%-a tartalmaz olyan, leggyakrabban a Dolichoderinae, Formicinae és Myrmicinae alcsaládokból kikerülő fajokat, amelyek trofobiotikus kapcsolatban állhatnak hemipterákkal, ezek többnyire arboreális, generalista táplálkozású, nagy létszámú, poligyn kolóniával rendelkező territoriális hangyák (Hölldobler és Wilson 1990; Delabie 2001; Styrsky és Eubanks 2007; Oliver és mtsai. 2008). Minthogy ezen fajok számbeli és viselkedésbeli dominanciájuk révén képesek monopolizálni a trofobiontáikat mint táplálékforrást, ezzel jelentősen lecsökkentve más hangyafajok lokális abundanciáját és diverzitását, a hemipterák így indirekt módon nagyban hozzájárulhatnak a hangyaközösségek szerveződéséhez, gyakran a fentebb már tárgyalt „hangyamozaikok” létrejöttét eredményezve (Blüthgen és mtsai. 2000, 2004; Pekas és mtsai. 2011).

A trofobiózis ezen formájának kialakulási ideje nem ismert pontosan, mindenesetre a paleogén időszakban már fennállhatott, legalábbis a 45 millió évvel ezelőttről, a középső eocénből származó balti és más egykorú borostyánban felfedezett †Germaraphis levéltetvek (Aphididae) és több hangyafaj (pl. †Prenolepis henschei, †Ctenobethylus goepperti, stb.) közös jelenléte ezt sugallja (Perkovsky 2006, 2011). Ennél már egy jóval specializáltabb, obligát jellegü kapcsolat egyértelmü bizonyítékát képviselik a 25 millió évvel későbbröl, az alsó miocénből származó dominikai borostyánkőben talált Acropyga ivaros nőstények $\dagger$ Electromyrmococcus viaszos-pajzstetvekkel (Pseudococcidae) a rágóik között, amelyeket a recens rokonfajokhoz hasonlóan szállíthattak nászrepüléskor a megalapítandó új kolónia mézharmatellátásának biztosítékaként (Johnson és mtsai. 2001).

A hangya-hemiptera trofobiotikus kapcsolat specificitása igen széles skálán változik. A legáltalánosabb interakció keretében a hangyák csupán a különböző szubsztrátumra (pl. levelekre, talajra, stb.) lehullott mézharmatot gyüjtik be anélkül, hogy direkt kontaktust létesítenének a hemipterákkal (Hölldobler és Wilson 1990; Delabie 2001). A közvetlen hangya-hemiptera kapcsolatok legnagyobb része alkalmi vagy fakultatív jellegü, az obligát mutualizmus különböző formái már jóval ritkábbak (Buckley 1987; Delabie 2001; Stadler és Dixon 2005; Oliver és mtsai. 2008). A kapcsolat flexibilitását jól példázzák az inváziós 
hangyafajok, amelyek új élöhelyre kerülve is könnyedén, rövid idő alatt képesek maguknak új trofobionta partnereket találni (Oliver és mtsai. 2008; Holzinger 2009). Amellett, hogy rendszeresen látogatják őket, számos hangyafaj készít „menedékhelyet” a trofobiontái számára, vagy gondozza őket a saját fészkében, ekként biztosítva számukra még hatékonyabb védelmet a természetes ellenségeiktől vagy az időjárás viszontagságaitól, egyszersmind megakadályozva a nem-szesszilis életmódú fajok egyedeinek szétszéledését és/vagy menekülését (Dietrich és McKamey 1990; Dejean és mtsai. 1996; Liefke és mtsai. 1998; BenDov és Fisher 2010). A legszorosabb, obligát jellegü kapcsolatok esetében a hangyagazda nagymértékben függ partnerétől (és gyakran vice versa), olyannyira, hogy a kolóniaalapítás csak a trofobionta megtelepítésével együtt lehet sikeres. Ilyen szoros gazda-szimbionta kapcsolat jellemzi pl. a különböző viaszos-pajzstetvekkel (Pseudococcidae) együtt élő Acropyga- és Tetraponera-fajokat (Klein és mtsai. 1992; Johnson és mtsai. 2001) vagy a Dolichoderus-génusz „,nomád” életmódú tagjait (Maschwitz és Hänel 1985).

Maguk a hangyák leggyakrabban levél- és pajzstetvekkel (Sternorrhyncha: Aphididae, Coccidae és Pseudococcidae), valamint púposkabócákkal (Auchenorrhyncha: Membracidae) létesítenek trofobiotikus kapcsolatot, más csoportok esetén az ilyesfajta asszociációk ritkák vagy legalábbis kevéssé ismertek (Hölldobler és Wilson 1990; Bourgoin 1997; Delabie 2001). Míg a növénytetvek, különösen a Coccidae és Pseudococcidae családok képviselői esetében jóval gyakoribb a hangyagazdával való specializáltabb interakció, addig a kabócák többnyire alkalmi kapcsolatban állnak a hangyákkal, és egyidejüleg rendszerint több faj is látogatja öket (Dejean és mtsai. 1996; Del-Claro és Oliveira 1999; Delabie 2001; Lehouck és mtsai. 2004; Steiner és mtsai. 2004; Maravalhas és Morais 2009).

A hangyagazda nyeresége ezen kapcsolatokból, hogy stabil, kiadós, térben és időben viszonylag jól prediktálható táplálékforrásra tesz szert (cukorra a mézharmatból, fehérjére a hemiptera-zsákmányból), miáltal a táplálékkeresés időtartama is jelentősen lecsökken. A florális- és extraflorális nektár mellett a mézharmat mindenekelőtt fontos energiaforrásként (kvázi „üzemanyagként”) szolgál a táplálékkereső dolgozók számára, emellett bizonyos fajoknál (az ún. mézesbödön-hangyáknál, pl. Myrmecocystus spp., Melophorus bagoti, Camponotus inflatus, stb.) raktározott táplálékként is funkcionál (Hölldobler és Wilson 1990). Az egyes hangyafajok mézharmatigénye természetesen igen változó, míg a tipikusan ragadozó életmódú fajok (pl. a Ponerinae és rokon alcsaládok képviselöi) csak ritkán hasznosítják, addig pl. az erdei vöröshangyák (Formica rufa-csoport) vagy a trópusi arboreális fajok étrendjének jelentős részét teheti ki (Hölldobler és Wilson 1990; Blüthgen és mtsai. 2000; Davidson és mtsai. 2003). A mézharmat igen gyakran az ökológiailag domináns 
fajok (köztük számos inváziós faj) sikerének kulcsa lehet, lévén a magasabb energia fokozottabb aktivitáshoz, nagyobb aktív dolgozóerőhöz, ezáltal gyorsabb és hatékonyabb táplálékkereséshez, valamint a táplálékforrás és territórium fokozottabb védelméhez vezethet (Davidson 1998). A hemiptera-partner nyeresége a higiénia, védelem az időjárás viszontagságaitól, a ragadozók (pl. Coleoptera: Coccinellidae, Diptera: Syrphidae, Araneae: Salticidae, stb.), parazitoidok (pl. Hymenoptera: Braconidae, Mymaridae, Aphelinidae, stb.), ill. kompetítorok ellen, a gazdanövény védelme más herbivoroktól, valamint a stabilabb populáció, gyorsabb ütemü növekedés és megnövekedett túlélési esély (Buckley 1987; Cushman és Whitham 1989; Hölldobler és Wilson 1990; Bach 1991; Bourgoin 1997; DelClaro és Oliveira 1999, 2000; Müller és Godfray 1999; Morales 2000; Moya-Raygoza és Nault 2000; Stadler és Dixon 2005).

Az azonban, hogy a hangyák gondozzák-e a trofobiontáikat nagyban függ azoknak a hozzáférhetőségétől, a kolóniától való távolságukkal, az aggregátumaik méretétől, a mézharmattermelö kapacitásuktól, a termelt mézharmat minőségétől, valamint attól, hogy milyen egyéb táplálékforrások állnak a hangyák rendelkezésére, ill. milyen nagy a kolónia fehérjeigénye (Cushman és Whitham 1989; Cushman 1991; Sakata 1995; Dejean és mtsai. 2000; Morales 2000; Moya-Raygoza és Nault 2000; Stadler és Dixon 2005). A kapcsolat ennek megfelelően erősen kontextusfüggő, térben és időben sok tényezőtől függően variál, így létrejötte, erőssége és kimenetele is nagy változatosságot mutat (Cushman és Whitham 1989; Del-Claro és Oliveira 2000; Billick és Tonkel 2003). Az interakció fenntartásához szükséges ráfordítást jelenti a hangyák részéről a trofobiontának és az általa termelt mézharmatnak a „kezelési költsége” (védelme, transzportja, stb.), míg a hemipterák részéről a hangyagazda számára kellően attraktív mennyiségű és minőségű mézharmat előállításának „metabolikus költsége”, valamint obligát mutualista kapcsolat esetén mindkét fél részéről az egymástól való erős, kölcsönös függés (Stadler és Dixon 2005).

A hangyákkal való asszociációt hemipterák esetében számos fiziológiai, morfológiai és viselkedésbeli változás kísérheti, ill. segítheti elő, ilyen pl. a csoportos, helytülő életmód, a vastag kutikula- és viaszréteg hiánya, az ugróképesség elvesztése, a mézharmat-kibocsátás mértékének növekedése, levéltetveknél a potrohcső redukciója, ill. az ún. „trofobiotikus szerv” megléte, vagy kabócáknál a kibocsátott mézharmatcsepp „,pulzáltatása” (Buckley 1987; Larsen és mtsai. 1992; Dejean és Bourgoin 1998; Delabie 2001; Steiner és mtsai. 2004; Stadler és Dixon 2005). A hangyagazdákra elsősorban a hemipterák szállításával és védelmével kapcsolatos viselkedésbeli változások jellemzőek, de olykor a territorialitás mértéke és az aktivitási mintázat is jelentősen megváltozhat (Mercier és Dejean 1996; Dejean 
és mtsai. 1997). A Formicinae és Dolichoderinae alcsalád képviselöinek sajátos (pre)adaptív bélyege ugyanakkor a tágulékony begy és a módosult előgyomor (proventriculus), amely nagy mennyiségü folyékony táplálék felvételét, raktározását és gyors emésztését teszi lehetővé (Eisner és Brown 1958; Davidson és mtsai. 2004), nagyban hozzájárulva ezen alcsaládok evolúciós sikeréhez (Wilson és Hölldobler 2005).

A gazdanövény mint harmadik fél számára a hangya-hemiptera kapcsolat többnyire nagyobb ráfordítással jár, mint előnnyel, ugyanis a hangyák védelme alatt nagyobb hemipterakolóniák fejlődhetnek ki, amelyek így intenzívebben táplálkoznak, emellett potenciális vektorai lehetnek különböző toxinoknak és növényi patogéneknek (Buckley 1987; Delabie 2001). Ha azonban a hemipterák denzitása alacsony marad, a hangya-hemiptera kapcsolatból a növénynek indirekt haszna is származhat, amennyiben hangyavédelemre tesz szert más herbivorok ellen és a mézharmat-akkumuláció is jelentősen lecsökken (Messina 1981; Bach 1991; Moreira és Del-Claro 2005; Oliveira és Del-Claro 2005; Styrsky és Eubanks 2007), bár ez nagyban függhet a rajta élő hangyafajoktól is (Dejean és mtsai. 1997). A trofobiózis kapcsolatrendszere tehát rendszerint igen komplex és szerteágazó, így az interakciók kimenetelét, valamint a ráfordítás-hasznon mértékét a résztvevő felek részéről rendre a nagyszámú pozitív és negatív hatások eredője fogja meghatározni (Buckley 1987; Delabie 2001; Oliveira és Del-Claro 2005) (1. ábra).

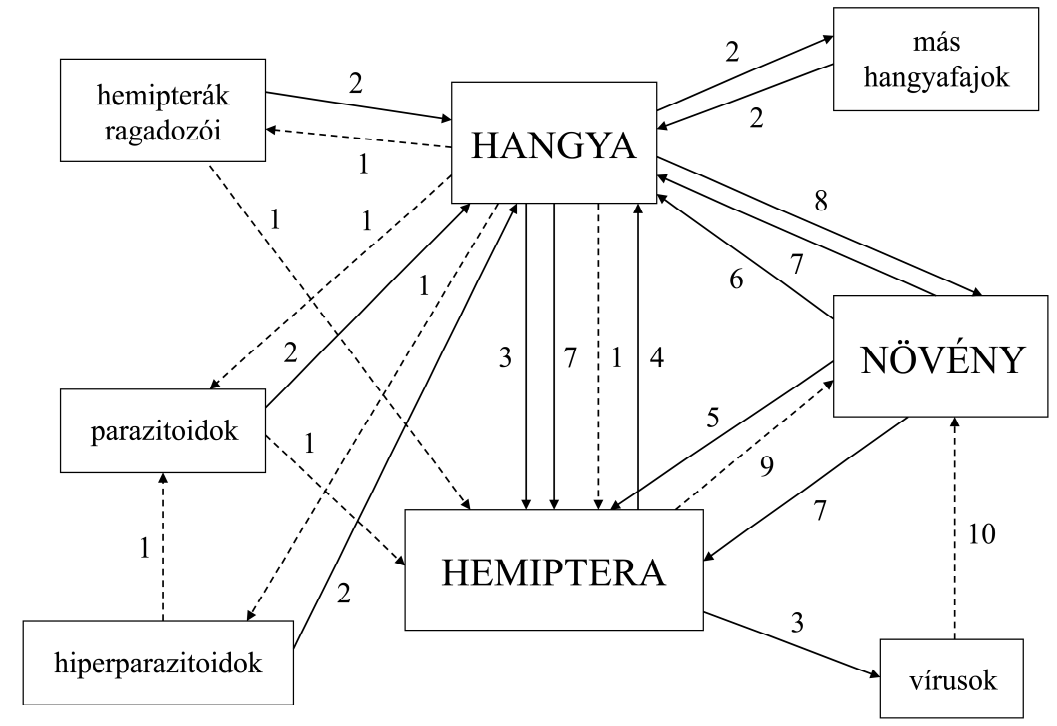

1. ábra. A trofobiózis kapcsolatrendszere (Delabie 2001 után, kissé módosítva). A folytonos vonalak a pozitív, a szaggatottak pedig a negatív jellegủ kapcsolatokat jelölik. (1): predáció/parazitoidizmus; (2): elkerülés; (3): szállítás/terjesztés; (4): mézharmat; (5): növényi nedvek; (6): florális- és extraflorális nektár; (7): fészkelőhely/élőhely; (8): növényevő-kontroll; (9): toxinok, gombák; (10): növényi betegségek. 


\section{Kérdések és hipotézisek}

Jelen dolgozatban bemutatott kutatásaim alapvető célja két szubmediterrán erdei hangyaközösség összetételének, ill. tér- és időbeli szerveződésének feltárása volt. Kérdéseim az alábbi két fő téma köré csoportosultak:

\section{Fészkek denzitásának és diszpergáltságának tér-idő mintázata:}

I. 1. Mely hangyafajok fészkelnek a legnagyobb számban és gyakorisággal a két vizsgálati élőhelyen?

I. 2. Milyen denzitásban vannak jelen ezen fajok fészkei? Változik-e a fészekdenzitás szezonálisan?

I. 3. Van-e különbség az egyes fajok fészkelőhely preferenciájában?

I. 4. Milyen típusú (ti. véletlenszerü, aggregált, szegregált) diszpergáltság jellemzi a fészkeket? Változik-e a fészkek términtázatának jellege szezonálisan?

I. 5. Befolyásolja-e a fészkek denzitása a términtázatuk jellegét?

I. 6. A legközelebbi konspecifikus vagy heterospecifikus fészekszomszédok közelségét preferálják-e jobban az egyes fajok kolóniái? Változik-e a fészekszomszéd-preferencia szezonálisan?

Hipotéziseim:

I. H. 1. A fészkelőhelyekért és/vagy táplálékért folytatott kompetíció szerepe jelentős a vizsgált közösségek szerveződésében, amely a fészkek szegregált términtázatában, ill. térbeli eloszlásuk egyenletességének fokozatos megnövekedésében fog megmutatkozni.

I. H. 2. A kolóniák mortalitása, esetleges időszakos költözése, a szezonálisan polidómuszos fajok populációinak jelenléte, stb. következtében a fészkek denzitása és términtázata szezonálisan változik.

I. H. 3. A denzitás növekedésével egyenes arányban nő a fészkek térbeli eloszlásának egyenletessége (denzitásfüggő diszpergáltság).

I. H. 4. A populáción belüli és a populációk közötti kompetíció egymáshoz viszonyított erősségétől függően a legközelebbi fészekszomszédok identitása eltérhet a véletlenszerűtől. 


\section{Táplálékszerzés tér-idő mintázata:}

II. 1. Mely hangyafajok látogatják legnagyobb számban és gyakorisággal a kihelyezett csalétkeket?

II. 2. Milyen napi- és szezonális aktivitási ritmus jellemzi a csalétkeket látogató fajokat? Milyen mértékủ az átfedés ezen fajok napi- és szezonális aktivitásában?

II. 3. Mely hőmérsékleti intervallumokban a legaktívabbak a csalétkeket látogató fajok? Milyen mértékủ a hőmérséklettől való függés?

II. 4. Különböznek-e az egyes fajok a csalétek felfedező képességük tekintetében? Befolyásolja-e a csalétkek felfedezési idejét a fészektől való távolság?

II. 5. Kimutatható-e különbség a szénhidrátban gazdag és a fehérjedús táplálékforrás preferenciájában? Változik-e a táplálékpreferencia szezonálisan?

II. 6. Milyen táplálkozási hatékonyság jellemzi a csalétkeket látogató fajokat?

II. 7. Milyen a csalétkeken való együttes előfordulás mértéke az egyes fajpárok esetében?

II. 8. Milyen interspecifikus viselkedési interakciók jellemzik a csalétkeket látogató fajokat? Hogyan alakulnak a dominanciaviszonyok?

Hipotéziseim:

II. H. 1. A különböző táplálékkészletekért folyó kompetíció meghatározó a vizsgált közösségek szerveződésében, így a kompetitív hierarchia magasabb szintjén álló domináns fajok rendre kizárják a csalétkekről a náluknál alacsonyabb szinten álló szubordinált fajok egyedeit, amely lineáris dominancia hierarchiák kialakulásához vezet.

II. H. 2. A domináns fajok csalétek felfedező képessége a szubordinált fajokénál jelentősen rosszabb (dominancia-forrásfelfedezés trade-off).

II. H. 3. A domináns fajok hőmérsékleti toleranciája a szubordinált fajokénál jelentősen alacsonyabb (dominancia-hőmérsékleti tolerancia trade-off).

II. H. 4. Az egyes fajok csalétkeken mutatott időbeli (napi- és/vagy szezonális) átfedésének mértéke a véletlenszerünél jóval kisebb (időbeli szegregáció).

II. H. 5. Az egyes fajok csalétkeken mutatott térbeli átfedésének mértéke a véletlenszerünél jóval kisebb (térbeli szegregáció). 
A fentebb vázolt két nagyobb volumenủ, közösségi jellegű vizsgálataimon túl egyéb, kisebb kutatásaim a vizsgált közösségek két meghatározó fajára, a Prenolepis nitensre és az Aphaenogaster subterraneára irányultak. Főbb kérdéseim az alábbiak voltak:

III. $\underline{P \text {. nitens téli aktivitása: }}$

III. 1. Észak-amerikai testvérfajához, a Prenolepis imparishoz hasonlóan a $P$. nitens is megőrzi-e télen az aktivitását?

III. 2. A lég- vagy a talajhőmérséklet befolyásolja-e inkább a táplálékkereső dolgozók aktivitását? Mi az a legalacsonyabb hőmérséklet, amelyen a táplálékkereső dolgozók még aktivitást mutatnak?

III. 3. A szénhidrátban gazdag vagy a fehérjedús táplálékforrást preferálják-e jobban a csalétkeket látogató dolgozók? Milyen természetes táplálékot gyüjtenek a dolgozók a téli időszakban?

IV. A. subterranea eszközhasználata:

IV. 1. Milyen egyedi viselkedésformák jellemzik a csalétkeken megjelenő, „eszközökkel” foglalatoskodó dolgozókat?

IV. 2. Mekkora az „eszközökkel” foglalatoskodó dolgozók aránya?

IV. 3. Milyen anyagokat használnak fel a dolgozók ,eszközként”?

IV. 4. Különbözik-e, és ha igen, milyen mértékben a folyékony táplálékforrásra és a hasonló halmazállapotú, ám tápláléknak nem minősülő anyagra adott reakció?

V. A. subterranea asszociációja recéskabócákkal:

V. 1. Obligát vagy inkább fakultatív jellegü a két faj közötti kapcsolat?

V. 2. Mekkora a kabócanimfák kolóniánkénti átlagos egyedszáma? Van-e összefüggés a kolóniaméret és a fészekben élö kabócanimfák egyedszáma között?

V. 3. Megfigyelhetö-e direkt interakció a két faj egyedei között? 


\section{Anyag és módszerek}

\subsection{Vizsgált fajok}

Vizsgálataim az alábbi fajokra összpontosultak, ill. az alább felsorolt fajok voltak azok, amelyek a vizsgált közösségek gyakoribb és/vagy meghatározó, domináns elemeinek bizonyultak, így ennek megfelelően az adatok feldolgozása, ill. az eredmények értékelése során nagyobb hangsúlyt kaptak:

Az Aphaenogaster subterranea (Latreille, 1798) egy viszonylag széles elterjedésü, Közép- és Dél-Európában, Moldovában, Dél-Ukrajnában, a Krím-félszigeten, Kis-Ázsiában és a Kaukázusban előforduló mediterrán hangyafaj (Kutter 1977; Czechowski és mtsai. 2012). Erősen melegkedvelő, kolóniái többnyire a meleg és mérsékelten nedves lombhullató erdőkben vagy azok szélén találhatók meg (Kutter 1977; Seifert 2007; Czechowski és mtsai. 2012), de tülevelü erdőkben (Garrido és mtsai. 2002; Lőrinczi 2008, 2011; Castracani és mtsai. 2010) és ritkán száraz gyepeken is előfordul (Csősz és mtsai. 2002; Dekoninck és mtsai. 2007; Seifert 2007). Kövek alatt, talajban, avarban, korhadt fában fészkel (Seifert 2007; Lörinczi 2011; Stukalyuk és Radchenko 2011; Czechowski és mtsai. 2012). Kolóniái többnyire monogynek, és több száz vagy több ezer dolgozóból is állhatnak (Schmid-Hempel és Crozier 1999; Seifert 2007; Stukalyuk és Radchenko 2011; Czechowski és mtsai. 2012). Mindenevő, és nemének sok más tagjához hasonlóan szintén eszközhasználó faj, amely a folyékony vagy félfolyékony táplálék elszállításához a környezetében fellelhető kisebb tárgyakat (pl. talajszemcséket, levéldarabokat, stb.) is felhasználja (Agbogba 1985; Lőrinczi, szem. megfigy.). Utódgondozása sajátos, a fészekbe hordott prédát ugyanis nem feldarabolva adja a lárváinak, hanem azokat hordja rá a táplálékra (Buschinger 1973). Feltehetőleg éjszakai életmódú (Seifert 2007; Czechowski és mtsai. 2012). Nászrepülésének ideje július vége és szeptember eleje közé esik (Seifert 2007). Noha az Aphaenogaster-fajokat általában opportunistának tekintik Andersen $(1995,1997,2010)$ funkcionális csoportfelosztását követve (pl. Wike és mtsai. 2010), az A. subterraneát Castracani és mtsai. (2010) klasszifikációjával ellentétben Gómez és mtsai. (2003) kriptikus fajként sorolták be.

A Prenolepis nitens (Mayr, 1853), nemének egyetlen recens európai képviselőjeként egy viszonylag szükebb elterjedésü jégkori reliktumfaj, amelynek elterjedési területe Itália északkeleti részétől Közép-Európán és a Balkán-félszigeten át keleten a Kaukázusig és 
Kis-Ázsiáig húzódik (Wheeler 1930; Bregant 1998; Vesnić és Lelo 2010). Bár elsődlegesen az 500 m-nél alacsonyabb tengerszint feletti magasságú, mediterrán-szubmediterrán klímájú élőhelyek tipikus fajaként tartják számon (Bregant 1998; Vesnić és Lelo 2010), Ausztria 1800-2200 m-es alpesi zónájából is leírták már előfordulását (Steiner és Schlick-Steiner 2001). Élőhelyei a meleg lomberdők, erdőszegélyek, ill. a szárazabb, nyíltabb területek (Bregant 1998; Csősz és mtsai. 2002), ám kultúrkövető faj lévén gyakran fordul elő a szőlőmüvelés alatt álló területeken, parkokban, kertekben, stb. is (Bregant 1998; Vörös és Gallé 2002). Népes kolóniái változatos helyeken, talajban, kövek alatt, fagyökerekben, falrepedésekben, elhalt fában fészkelnek (Bregant 1998; Lőrinczi 2011). Biológiája kevéssé ismert. Táplálékának jelentős részét feltehetőleg különféle édes nedvek (pl. mézharmat, florális- és extraflorális nektár, gyümölcsök nedvei, stb.) teszik ki (Röszler 1937; Bregant 1998). Szőlősökben nagy ritkán károkat is okozhat a termés fogyasztásával (Vörös és Gallé 2002). Közép-Európában az egyetlen ún. mézesbödön-hangyafaj, amelynek fizogasztriás dolgozói élő táplálékraktárként szolgálnak a kolónia, és ezen belül is elsődlegesen a fészekben áttelelő ivaros alakok számára (Röszler 1937; Halmágyi 1978). Eltérően azonban pl. az újvilági Myrmecocystus-fajoktól, a $P$. nitens mézesbödön-dolgozói nem képeznek különálló kasztot, sőt, mivel mozgékonyságukat is nagyrészt megőrzik, korlátozott mértékben az ivadékgondozásban is képesek részt venni (Röszler 1937; Bregant 1998). Emellett, az északamerikai testvérfajához, a $P$. imparishoz hasonlóan a táplálékraktározás ennél a fajnál is nagy valószínüség szerint sokkal inkább a hipertrofizált zsírtestben raktározott lipidek és más tápanyagok, mintsem a begyben tárolt folyékony táplálék formájában történik (Tschinkel 1987). Seifert (2007) szerint a faj a téli hidegre érzékeny, ám a márciustól októberig tartó aktivitásának idején nem kifejezetten melegkedvelö. Nászrepülése is igen koránra, március vége és május eleje közé esik (Röszler 1937; Andrásfalvy 1961; Bregant 1998; Seifert 2007). Kolóniaalapítása önálló (Andrásfalvy 1961), habár Röszler (1937) szerint jellemző a pleometrózis, sőt, a Lasius emarginatust mint segédhangyát felhasználva a temporális szociálparazitizmus sem kizárható.

A Lasius (Lasius s. str.) emarginatus (Olivier, 1792) egy euro-kaukázusi elterjedésü, Közép- és Dél-Európa, a Kaukázus és Kis-Ázsia mediterrán és szubmediterrán régióiban előforduló hangyafaj (Kutter 1977; Seifert 1992, 2007; Gallé és mtsai. 2005; Czechowski és mtsai. 2012). Szárazságkedvelő, a nedves helyeket kerüli (Kutter 1977; Czechowski és mtsai. 2012). Közép-Európában alnemének egyik leginkább melegkedvelő faja (Seifert 1992; Czechowski és mtsai. 2012). Természetes élőhelyei a szárazabb erdők és gyepek, Közép- 
Európában különösen gyakori a gyér vegetációjú, napsütötte sziklás élőhelyeken (Seifert 1992, 2007; Czechowski és mtsai. 2012). Leggyakrabban sziklarepedésekbe, kövek közé, kövek alá, talajba vagy elhalt fába fészkel (Kutter 1977; Seifert 2007; Lőrinczi 2011; Stukalyuk és Radchenko 2011; Czechowski és mtsai. 2012). Helyenként nagy fészekdenzitást is elérhet (Seifert 1992; Lőrinczi 2011). Olykor városokban is gyakori, ahol fészkei falrepedésekben, korhadó gerendában, sőt még az aszfalt alatt is megtalálhatók (Seifert 2007; Czechowski és mtsai. 2012). Maga a fészek gyakran kartonszerü belső struktúrával rendelkezik, ennek alapanyagát összerágott famorzsalék és talajszemcsék regurgitált mézharmattal összekevert elegye képezi (Seifert 2007; Czechowski és mtsai. 2012), amelynek az ezen mint szubsztráton növekvő gombahifák adnak további szilárdságot (Seifert 1992, 2007). Kolóniái népesek, a dolgozószám élőhelytől függően több száztól néhány tízezerig is terjedhet (Stukalyuk és Radchenko 2011). Monogyn, bár kolóniaalapításakor pleometrózis is előfordulhat (Seifert 2007; Czechowski és mtsai. 2012). Nemének leggyorsabban mozgó, legjobban tájékozódó és leghatékonyabban rekrutáló faja, dolgozói a kolónia mintegy 40 m-es körzetében gyüjtenek táplálékot (Seifert, 2007). Ragadozó, mézharmat- és nektárfogyasztó (Seifert 2007; Czechowski és mtsai. 2012). Más hangyafajokkal szemben meglehetősen agresszív (Seifert 2007; Czechowski és mtsai. 2012), ezektől táplálkozási területét többnyire aktívan védelmezi (Seifert 1992; Stukalyuk és Radchenko 2011). Nászrepülésének ideje a szabadban élő kolóniák esetén július közepe és augusztus vége közé, alkonyat tájékára esik (Andrásfalvy 1961; Kutter 1977; Seifert 1992, 2007; Czechowski és mtsai. 2012).

A Formica (Serviformica) fusca Linnaeus, 1758 egy igen széles földrajzi elterjedésü transzpalearktikus faj, amelynek elterjedési területe Nyugat- és Dél-Európától Skandináviáig (a 65. szélességi fokig), ill. kelet felé a Kaukázuson és Kis-Ázsián át egészen Közép-Ázsiáig húzódik (Kutter 1977; Collingwood 1979; Gallé és mtsai. 2005; Seifert 2007; Czechowski és mtsai. 2012), ám adventív fajként Észak-Amerikában, Kubában, a Kanári-szigeteken és Szumátrán is előfordul (Czechowski és mtsai. 2012). Mérsékelten meleg- és nedvességkedvelő faj (Gallé és mtsai. 2005; Seifert 2007). Élőhelyei igen változatosak, a homokdünéktől és a szárazabb, napsütötte domboldalaktól a réteken, erdei tisztásokon és a ritkás, fiatal erdőkön át a tőzegmohás lápokig és a nedvesebb, gazdag aljnövényzetű zártabb erdőkig mindenhol előfordul (Csősz és mtsai. 2002; Seifert 2007; Czechowski és mtsai. 2012). Olykor még városok peremterületein is megtelepedhet (Seifert 2007). Változatos helyeken, talajban, kövek alatt, korhadt fában, avarban, stb. fészkel, néha fészekdombot készít (Kutter 1977; Collingwood 1979; Seifert 2007; Lőrinczi 2011; Czechowski és mtsai. 2012). 
A napsütötte, melegebb erdőkben viszonylag nagy fészekdenzitást (akár 28 fészek/100 $\mathrm{m}^{2}$ ) is elérhet (Seifert 2007). Kolóniái mono- vagy oligogynek néhány száz (max. 2000) dolgozóval (Collingwood 1979; Seifert 2007; Czechowski és mtsai. 2012). Kolónialapítása többnyire önálló, de jellemző lehet a pleometrózis, ill. a konspecifikus kolóniákba történő adoptálás is (Seifert 2007). Gyakran él pleziobiózisban más hangyafajokkal (Kanizsai és mtsai. 2013). Ragadozó, de emellett nektárt és mézharmatot is fogyaszt (Collingwood 1979; Seifert 2007; Czechowski és mtsai. 2012). Alnemének több más tagjához hasonlóan a kompetitív hierarchiában szubordinált faj, amelynek dolgozói a fészken kívül félénkek, nem agresszívak (Collingwood 1979; Seifert 2007; Czechowski és mtsai. 2012), bár a nagyobb kolóniák a látogatott levéltetveket védelmezhetik bizonyos Lasius-fajoktól, ill. számbeli fölény esetén olykor még az erdei vöröshangyák felderítő egyedeit is elpusztíthatják (Seifert 2007). Európában a szociálparazita Formica-, ill. Polyergus-fajok egyik leggyakoribb segéd-, ill. rabszolgahangyája a Serviformica-fajok között (Czechowski és mtsai. 2012). Nászrepülése július-augusztusban, a nappali órákban zajlik (Collingwood 1979; Seifert 2007; Czechowski és mtsai. 2012).

A Formica (Serviformica) gagates Latreille, 1798 elterjedési területe Közép- és DélEurópa, a Krím-félsziget, a Kaukázus és Kis-Ázsia (Kutter 1977; Seifert 2007). Melegkedvelő faj (Seifert 2007). Élőhelyei a szárazabb, nyíltabb elegyes lomberdők, ill. ezek szegélyei (Kutter 1977; Seifert 2007). Többnyire talajban, kövek alatt, korhadt fában fészkel, néha fészekdombot készít (Seifert 2007; Lőrinczi 2011; Stukalyuk és Radchenko 2011). Kolóniáinak mérete változó, több száz, de akár néhány tízezer dolgozóból is állhatnak (Stukalyuk és Radchenko 2011). Ragadozó és mézharmatfogyasztó (Stukalyuk és Radchenko 2011). A nagyobb, feltehetően poligyn kolóniák táplálkozási területüket (beleértve a fákon lévő levéltetü-kolóniáikat) más hangyafajoktól védelmezik (Seifert 2007; Stukalyuk és Radchenko 2011). Nászrepülése június közepe és augusztus vége között zajlik (Seifert 2007).

A Temnothorax Mayr, 1861 széles elterjedésű, igen fajgazdag neméből a két vizsgálati élőhelyen három faj, a T. crassispinus (Karawajew, 1926), T. parvulus (Schenck, 1852) és a $\boldsymbol{T}$. unifasciatus (Latreille, 1798) fordult elö leggyakrabban. A génusz tagjai rendszerint apró termetü, üregi fészkelő fajok, kis dolgozószámú, többnyire monogyn kolóniákkal (Seifert 2007; Czechowski és mtsai. 2012). Túlnyomó részt ragadozók, hemipterákat nem látogatnak, legfeljebb a lecsepegett mézharmatot fogyasztják (Seifert 2007). 
A T. crassispinus egy euro-kaukázusi faj, amelynek elterjedési területe Közép-Európa keleti részétől a Balkán-félszigeten át keleten az Urál hegységig és a Kaukázusig húzódik (Czechowski és mtsai. 2012). A Nyugat-Európában és Közép-Európa nyugati részén honos Temnothorax nylanderi parapatrikus testvérfaja, amellyel az elterjedésük határvonala mentén rendszeresen hibridizál, ill. hoz létre kevert kolóniákat a heterospecifikus kolóniafúziók eredményeként (Pusch és mtsai. 2006; Seifert 2007; Czechowski és mtsai. 2012). Mérsékelten meleg- és nedvességkedvelő faj, élőhelyei elsősorban a nyíltabb lombelegyes fenyő- és tülevelü erdők, de a szárazabb lomberdőkben, gyepeken, ill. városok izoláltabb, fás-bokros élőhelyein is előfordul (Csősz és mtsai. 2002; Seifert 2007; Czechowski és mtsai. 2012). Korhadt faágakban, farönkökben, kéreg alatt, mohában, avarban, ill. termésekben, gubacsokban fészkel (Seifert 2007; Białas és mtsai. 2011; Lőrinczi 2011; Czechowski és mtsai. 2012). Helyenként magas, ill. extrém magas fészekdenzitást (238-869 fészek/100 $\left.\mathrm{m}^{2}\right)$ is elérhet (Strätz és Heinze 2004; Białas és mtsai. 2011). Kolóniái monogynek, évszaktól függően változó számú (max. 100-200) dolgozóval (Seifert 2007; Białas és mtsai. 2011; Czechowski és mtsai. 2012). Kolónialapítása a T. nylanderihez hasonlóan többnyire pleometrózissal történik (Seifert 2007), a királynők kolóniafoglalása, ill. a konspecifikus kolóniák fúziója azonban ennél a fajnál jóval ritkábbnak tủnik (Strätz és Heinze 2004). Nemének több más tagjához hasonlóan szezonálisan polidómuszos faj, nyárra az egyes kolóniák néhány tucat dolgozóból álló kisebb egységekre bomlanak fel, melyek mindegyike külön fészkelőhelyet foglal el, ezek egyikében a királynővel (Strätz és Heinze 2004; Seifert 2007; Białas és mtsai. 2011; Czechowski és mtsai. 2012). Nászrepülésének ideje július közepe és szeptember közepe közé, naplemente tájékára esik (Seifert 2007; Czechowski és mtsai. 2012).

A T. parvulus egy mediterrán elterjedésü faj, amely Nyugat-, Közép- és DélEurópában (valamint Gotland- és Öland szigetén), Kelet-Európa délkeleti részén, Észak-Afrika északnyugati részén, a Kaukázusban, Kis-Ázsiában, Iránban és a Kopet-dag hegységben fordul elő (Kutter 1977; Czechowski és mtsai. 2012). Meleg- és szárazságkedvelő faj, élőhelyei a szárazabb, nyíltabb lomberdők, elsősorban tölgyesek (Seifert 2007; Czechowski és mtsai. 2012). Monogyn, néhány tucat (max. 100-200) dolgozóból álló kolóniái talajban, korhadt fában, kövek alatt, avarban, mohában, termésekben, gubacsokban fészkelnek (Kutter 1977; Seifert 2007; Stukalyuk és Radchenko 2011; Czechowski és mtsai. 2012). Fészkeinek denzitása helyenként igen magas (139 fészek/100 $\mathrm{m}^{2}$ ) is lehet (Seifert 2007). Tavasszal a T. crassispinushoz hasonló kolóniahasadás jellemzi (Seifert 2007). Nászrepülése 
viszonylag későn, augusztus eleje és szeptember közepe között, a napfelkeltét követő órákban zajlik (Seifert 2007; Czechowski és mtsai. 2012).

A T. unifasciatus egy szélesebb elterjedésű, euro-kaukázusi faj, amely az 52. szélességi foktól délre (valamint Gotland szigetén), keleten az Urál hegységig egész Európában, a Kaukázusban, Kis-Ázsiában, a Kopet-dag hegységben és Marokkóban elterjedt (Kutter 1977; Collingwood 1979; Seifert 2007; Czechowski és mtsai. 2012). Meleg- és szárazságkedvelő (Seifert 2007; Czechowski és mtsai. 2012). A különféle xeroterm erdők és gyepek gyakori faja, de városok kevésbé zavart részein (pl. temetőkben, régi városfalak környékén) is előfordul (Seifert 2007; Czechowski és mtsai. 2012). Korhadt faágakban, üreges növényi szárakban, kéreg alatt, sziklarepedésekben, kövek alatt, zuzmó alatt fészkel (Kutter 1977; Collingwood 1979; Seifert 2007; Czechowski és mtsai. 2012). Az előző két fajhoz hasonlóan helyenként igen nagy fészekdenzitást $\left(120\right.$ fészek/100 $\left.\mathrm{m}^{2}\right)$ is elérhet (Seifert 2007). Relatíve népes kolóniái monogynek, akár 200 vagy annál is több dolgozóval (Collingwood 1979; Martin és mtsai. 1995; Seifert 2007; Czechowski és mtsai. 2012). Nászrepülésének ideje június közepe és augusztus vége közé, napfelkelte tájékára esik (Seifert 2007; Czechowski és mtsai. 2012).

A Reptalus panzeri (Löw 1883) a recéskabóca-félék családjába (Cixiidae) tartozó, Közép- és Dél-Európában, Angliában, a Kaukázusban és Kis-Ázsiában elterjedt kabócafaj (Holzinger és mtsai. 2003). Főként a száraz és meleg élőhelyeket kedveli, különösen gyakori a napsütötte domboldalakon vagy az 500 m-t meg nem haladó fennsíkokon (Holzinger és mtsai. 2003). Polifág faj, gazdanövényei igen változatosak, fás- és lágyszárú növények egyaránt lehetnek (Nickel és Remane 2002; Nickel 2003; Jović és mtsai. 2009; Bertin és mtsai. 2010). A család többi tagjához hasonlóan a jellegzetes viaszos fartoldalékkal rendelkező nimfái a talajban élnek, ahol gazdanövényeik gyökereit szívogatják. Egy évben egyetlen generációja van, az áttelelés nimfa állapotban történik, az imágók június közepétől augusztus elejéig aktívak (Nickel és Remane 2002; Holzinger és mtsai. 2003; Jović és mtsai. 2009). Gazdasági szempontból jelentős faj, ugyanis potenciális vektora a növényi floémben élő sztolbur fitoplazma baktériumoknak, amelyek számos kultúrnövényfajban váltanak ki megbetegedéseket (Palermo és mtsai. 2004; Riedle-Bauer és mtsai. 2006; Jović és mtsai. 2007, 2009). 
A fentebb felsoroltak mellett az alábbi hangyafajok kerültek még felvételezésre a két élőhelyen a vizsgálatok során: Camponotus aethiops (Latreille, 1798); Camponotus fallax (Nylander, 1856); Camponotus ligniperdus (Latreille, 1802); Camponotus truncatus (Spinola, 1808); Crematogaster schmidti (Mayr, 1853); Formica pratensis Retzius, 1783; Lasius brunneus (Latreille, 1798); Lasius citrinus Emery, 1922; Lasius myops Forel, 1894; Lasius umbratus (Nylander, 1846); Liometopum microcephalum (Panzer, 1798); Myrmecina graminicola (Latreille, 1802); Myrmica sabuleti Meinert, 1861; Myrmica schencki Viereck, 1903; Plagiolepis taurica Santschi, 1920; Ponera coarctata (Latreille, 1802); Temnothorax affinis (Mayr, 1855).

\subsection{Vizsgálati élőhelyek}

Vizsgálataimat a Dunántúli-középhegységben, a Balaton-felvidék két erdős élöhelyén végeztem. A régió éghajlata enyhe, kifejezetten szubmediterrán jellegü, $10-15^{\circ} \mathrm{C}$-os évi középhőmérséklettel és 650-700 mm évi átlagos csapadékmennyiséggel (Füleky és mtsai. 2007). Az első vizsgálati terület, a Péter-hegy a Balaton-felvidék középső részén, Csopaktól Balatonfüred-Arácsig húzódik délnyugati irányban mintegy $2 \mathrm{~km}$ hosszúságban, míg a második, a Mogyorós-hegy előbbitől légvonalban kb. 17 km-re, északkeletre fekszik Litér és Királyszentistván községek között. A terepi vizsgálatokra mindkét területen a hegyek déli fekvésü lejtőin került sor (1. táblázat).

1. táblázat. A két vizsgálati élőhely földrajzi adatai.

\begin{tabular}{lcc}
\hline & I. & II. \\
terület & Péter-hegy & Mogyorós-hegy \\
koordináta & é.sz. $46^{\circ} 58^{\prime} 33,54^{\prime \prime}$ & é.sz. 47 05' 47,22" \\
& k.h. $17^{\circ} 53^{\prime} 34,62^{\prime \prime}$ & k.h. $18^{\circ} 01^{\prime} 29,52^{\prime \prime}$ \\
tszf. magasság & $207 \mathrm{~m}$ & $220 \mathrm{~m}$ \\
lejtőszög & $15-20^{\circ}$ & $5-10^{\circ}$ \\
kitettség & déli & déli \\
\hline
\end{tabular}

A Péter-hegy déli lejtőjét karsztbokorerdő (Cotino-Quercetum pubescentis) és molyhos tölgyes (Vicio sparsiflorae-Quercetum pubescentis) mozaikja borítja (Borhidi 2003), benne molyhos tölggyel (Quercus pubescens) és virágos körissel (Fraxinus ornus) mint 
domináns fafajokkal (2. ábra). Részletes adatokkal a terület vegetációjáról Debreczy (1973) cikke szolgál.

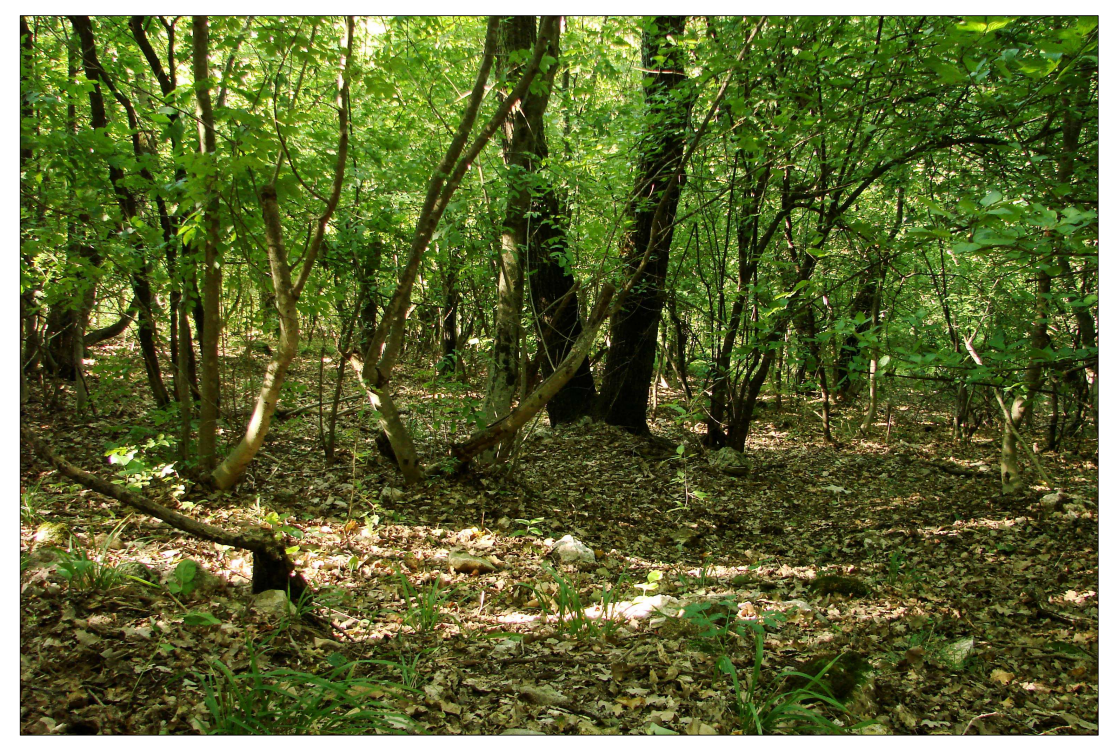

2. ábra. A balatonfüredi Péter-hegy déli lejtőjének karsztbokorerdeje.

A Mogyorós-hegy déli lejtőjének erdei lombosfákkal (többnyire virágos kőrissel) különböző mértékben elegyes feketefenyő (Pinus nigra) állományokból állnak, mely utóbbiakat az 1960-as, 1970-es években telepítettek kopárfásítási célból (Tamás 2003) (3. ábra).

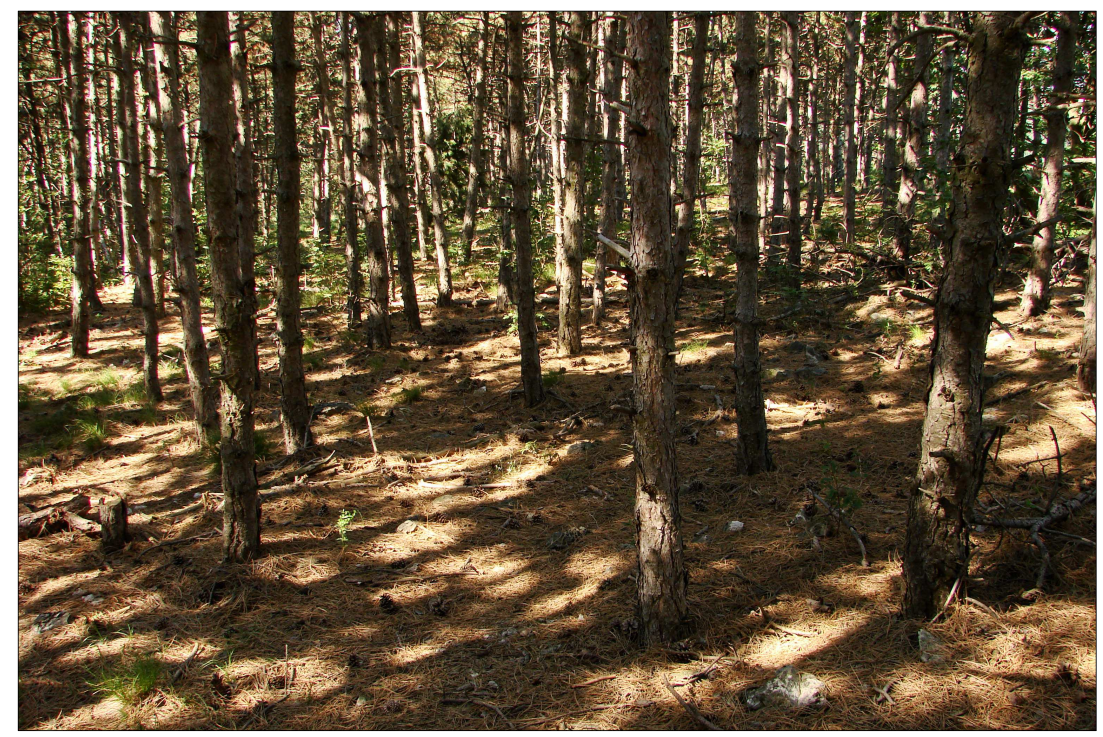

3. ábra. A litéri Mogyorós-hegy déli lejtőjének lombelegyes feketefenyvese.

A továbbiakban az egyszerüség kedvéért a két vizsgálati élőhelyre rendre mint "füredi tölgyes" és "litéri fenyves" fogok hivatkozni. 


\subsection{Terepi vizsgálatok}

Fészkek denzitásának és términtázatának vizsgálata

A hangyafészkek egy adott területen vagy különböző nagyságú mintavételi egységekben (pl. kvadrátokban) történő számbavétele, ill. térképezése az adott közösség faji összetételének becslése mellett a kolóniák denzitásának, diszpergáltságának, ill. térbeli kapcsolatainak meghatározására, valamint demográfiai folyamatainak feltárására is alkalmas vizsgálati módszer (Bestelmeyer és mtsai. 2000; Schlick-Steiner és mtsai. 2006), amely a térbeli mintázatok és folyamatok elemzése révén közvetve információval szolgálhat a közösséget alakító vagy az azon belül zajló mechanizmusokról, így pl. a kompetíciónak az adott közösség szerveződésében betöltött jelentőségéről is (pl. Bernstein és Gobbel 1979; Levings és Traniello 1981; Levings és Franks 1982; Ryti és Case 1984, 1986, 1992; Cushman és mtsai. 1988). A fészkek számának és térbeli pozíciójának különböző évszakokban és/vagy egymást követő években végzett monitorozásai egyúttal a tér- és időbeli mintázatok, ill. ezek hátterében húzódó folyamatok együttes vizsgálatát is lehetővé teszik (pl. Herbers 1985, 1989, 2011; Petrov és Gallé 1986; Traniello és Levings 1986; Gallé és mtsai. 1994; Cerdá és mtsai. 2002; Dillier és Wehner 2004). Destruktivitásán és időigényességén túl a módszer hátrányai közé tartozik ugyanakkor, hogy a nem feltünő fészekstruktúrával rendelkező fajok kolóniái könnyen alul-, míg a polidómuszos és/vagy több fészekkijárattal rendelkező fajok kolóniái (a bizonytalan kolónia- és fészekhatárok miatt) túlreprezentálódhatnak a felvételezések során, ami pontatlan becslésekhez vezethet (Herbers 1985; Gallé 1991; Andersen 1997; Bestelmeyer és mtsai. 2000; Debout és mtsai. 2007).

Vizsgálataim során a hangyafészkeket mindkét élőhelyen 3-3 véletlenszerüen elhelyezett, $7 \mathrm{~m} \times 7$ m-es kvadrátban térképeztem 2010 tavaszától őszéig négy különböző időszakban (összesen: 3 kvadrát $\times 4$ időszak × 2 élőhely = 1176 m²) (2. táblázat).

2. táblázat. A fészektérképezések időpontjai a két vizsgálati élőhelyen.

\begin{tabular}{lccccc}
\hline & Füredi tölgyes & Litéri fenyves & Füredi tölgyes & Litéri fenyves \\
tavasz & ápr. 2. & máj. 1. & nyár vége & aug. 17. & aug. 22. \\
& ápr. 9. & máj. 9. & & aug. 27. & szept. 12. \\
& ápr. 26. & máj. 29. & & szept. 13. & szept. 18. \\
nyár eleje & jún. 12. & jún. 27. ősz & okt. 9. & okt. 11. \\
& jún. 28. & júl. 4. & & okt. 16. & okt. 15. \\
& júl. 8. & júl. 11. & & okt. 22. & okt. 24. \\
\hline
\end{tabular}


Az élőhelyek foltozottságának potenciális hatását minimalizálandó, a térképezéshez mindkét élőhelyen egy-egy kellőképpen nagy, összefüggő, homomorf (homogénnek tünő) foltot választottam ki gyér aljnövényzettel vagy szinte anélkül, valamint az egyes kvadrátokat minden időszakban a korábban elhelyezettek közelében jelöltem ki.

A felvételezések során a kvadrátok területét a talaj felsőbb rétegétől az avarrétegen át egészen a földre hullott korhadt faágakig, gallyakig, ill. termésekig (pl. makk), gubacsokig és üres csigaházakig alaposan átvizsgálva térképeztem fel az itt fészkelő hangyakolóniákat, rögzítve az egyes fészkek koordinátáit, ill. feljegyezve a fészkelöhely típusát is (kő alatt, talajban, avarban, stb.). Fészeknek minden olyan diszkréten elkülönülő egységet tekintettem, amelyet egy adott kolónia vagy egy nagyobb dolgozócsoport (pl. polidómuszos fajok esetében) foglalt el. Azoknak a fajoknak a kolóniáiból, amelyeket a terepen nem tudtam kellő bizonyossággal azonosítani (pl. Temnothorax spp.) mintaegyedeket gyüjtöttem be, és később laborban határoztam meg Seifert (2007), ill. Czechowski és mtsai. (2002) határozókulcsai alapján. A terepi felvételezések után minden kvadrátról a fészkek térbeli pozícióját tartalmazó minitérkép készült (4. ábra).
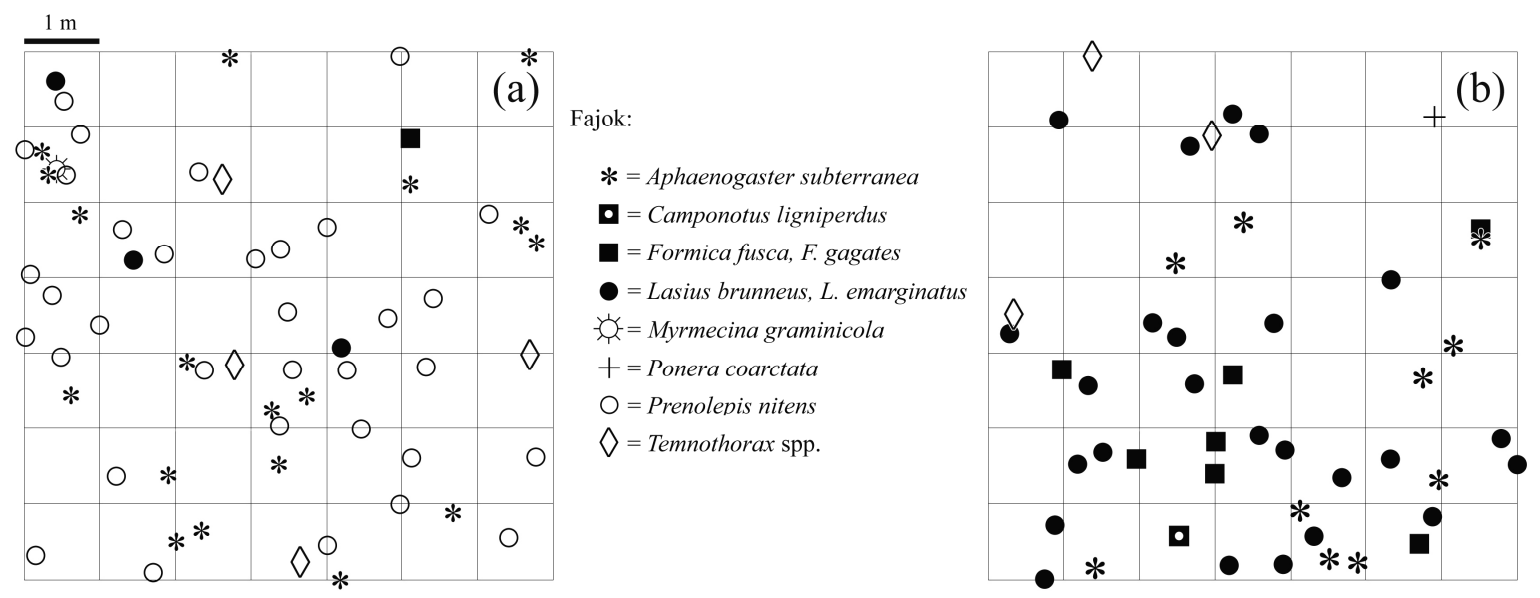

4. ábra. Példa a fészkek térbeli pozícióját ábrázoló minitérképekre a két vizsgálati élőhelyröl. (a): füredi tölgyes (tavasz/2); (b): litéri fenyves (nyár eleje/3).

\section{Csalétkes vizsgálatok}

A csalétkes mintavételezés, egyszerűségénél és hatékonyságánál fogva a közösségi szintű vizsgálatok egyik leggyakrabban, legszélesebb körben alkalmazott módszere, amely a fajösszetétel és relatív gyakoriság becslésén túl az egyes fajok táplálkozási stratégiájának, táplálékpreferenciájának, napi- és szezonális aktivitásának meghatározására, valamint a fajok közötti viselkedési interakciók, ill. kompetíciós és dominanciaviszonyok vizsgálatára is 
lehetőséget nyújt (pl. Lynch és mtsai. 1980; Fellers 1987, 1989; Savolainen és Vepsäläinen 1988, 1989; Vepsäläinen és Savolainen 1990; Gallé 1991; Andersen 1992; Cerdá és mtsai. 1997, 1998a; Cros és mtsai. 1997; Bestelmeyer 2000; Bestelmeyer és mtsai. 2000; Albrecht és Gotelli 2001; Hahn és Wheeler 2002; LeBrun 2005; Lessard és mtsai. 2009; Wittman és mtsai. 2010; Stuble és mtsai. 2013). A módszer hátrányai közé tartozik ugyanakkor, hogy a táplálékspecialisták, ill. a szubordinált vagy egyéni táplálékkeresést végző fajok jelentősen alulreprezentálódhatnak a felvételezések során a generalista táplálkozású, ill. a csalétkeket nagy egyedszámmal monopolizáló, tömegrekrutáló domináns fajokkal szemben, valamint hogy a könnyen hozzáférhető, tartós táplálékforrást imitáló csalétkek attraktivitásuknál fogva könnyen megváltoztathatják a látogató fajok természetes aktivitási mintázatát (Whitford és mtsai. 1980; Andersen 1997; Bestelmeyer és mtsai. 2000; Sanders és Gordon 2000; Ribas és Schoereder 2002; Markó és Czechowski 2004; Czechowski és Markó 2005).

A csalétkes vizsgálatokat a fészektérképezéshez hasonlóan mindkét élöhelyen négy különböző időszakban, 2011 tavaszától őszéig végeztem ugyanabban a fentebb már jellemzett élőhelyfoltban (3. táblázat).

3. táblázat. A csalétkezések időpontjai a két vizsgálati élőhelyen.

\begin{tabular}{lccccc}
\hline \multirow{2}{*}{ tavasz } & Füredi tölgyes & Litéri fenyves & & Füredi tölgyes & Litéri fenyves \\
& ápr. 3. & ápr. 18. & nyár vége & aug. 12. & aug. 15. \\
& ápr. 17. & ápr. 23. & & aug. 29. & aug. 22. \\
myár eleje & máj. 7. & máj. 10. & & szept. 10. & szept. 4. \\
& jún. 18. & jún. 13. ősz & okt. 10. & okt. 3. \\
& jún. 27. & jún. 21. & & okt. 29. & okt. 17. \\
& júl. 10. & júl. 4. & & nov. 6. & okt. 31. \\
\hline
\end{tabular}

A terepkísérletek során zöld színü, kör, ill. félkör alakú, $8 \mathrm{~cm}$-es átmérőjü müanyag lapokat alkalmaztam, előbbieket a talajfelszínre, utóbbiakat pedig fák törzsére, kb. 1-1,5 m-es magasságban, vízszintes helyzetben elhelyezve, ill. feltüzve (Függelék 1. ábra). Csaliként porcukorral kevert virágmézet és vízbe áztatott, aprított tonhalat használtam, amelyekböl mindig közel azonos mennyiségű adag (valamivel kevesebb mint negyed teáskanálnyi) került a csalilapokra egymástól kb. $5 \mathrm{~cm}$-es távolságban, ezzel megadva a szénhidrátban gazdag és fehérjedús táplálékforrás közötti választás lehetőségét a látogató hangyák számára. (A méz porcukorral való sürítését a hangyák mézbe való beleragadásának, ill. a mézcsepp csalilapról való lefolyásának elkerülése indokolta.) 


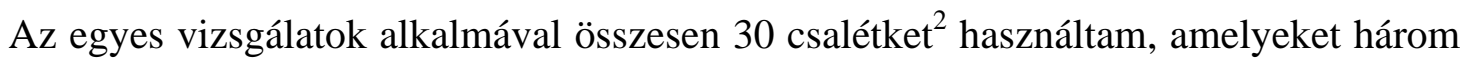
csoportban, véletlenszerủen helyeztem el, egymástól kb. 15-15 m-re. Minden egyes csalétekcsoport 5-5 talajra, ill. 5-5 fára elhelyezett csalétekből állt, egyenként kb. 3 m-es térközökkel elválasztva egymástól. A felvételezések a tavasztól nyár végéig tartó időszakban 12 órán át (7:00-19:00), az öszi időszakban pedig (a rövidebb nappalok miatt) 10 órán át (8:00-18:00), óránként történtek 7:00-ás, ill. 8:00-ás kezdéssel, mintegy háromnegyed órával a csalétkek kihelyezése után (összesen: $6480=30$ csalétek $\times 12$ felvétel $\times 9$ nap $\times 2$ élőhely + $1800=30$ csalétek $\times 10$ felvétel $\times 3$ nap $\times 2$ élöhely). A kb. 1 perces észlelések során minden egyes csalétken azonosítottam a rajtuk megjelenő hangyákat, rögzítettem az egyedszámukat, feljegyeztem a tartózkodási helyüket, és az alábbi viselkedésformákat különítettem el: (1) a csalin táplálkozik ("eszik"); (2) különösebb tevékenység nélkül tartózkodik a csalétken ("jelen"); (3) más faj/kolónia egyedével/egyedeivel szemben támadólag lép fel ("agresszív"); (4) egy másik faj/kolónia egyedének/egyedeinek jelenléte vagy agresszív megnyilvánulása miatt a csalétket elhagyni kényszerül ("menekül"). A csalilapra kihelyezett táplálékot gyors fogyás esetén folyamatosan pótoltam.

A felvételezésekkel párhuzamosan óránként mértem a talajfelszíni léghőmérsékletet és kb. $15 \mathrm{~cm}$ mélyen a talajhőmérsékletet digitális termométer segítségével. A kísérletek során, amikor csak lehetőség nyílt rá, a csalétkeket látogató dolgozókat a táplálkozási ösvényeik mentén rendre visszakövettem a fészkükig, majd feljegyeztem a csalétek-fészek távolságokat. A terepen való identifikálásuk nehézkes mivolta miatt a Temnothorax-fajokat csak génusz szintig azonosítottam a vizsgálat során, azonban a legutolsó felvételezéseket követően, amennyiben ekkor még jelen voltak a csalétkeken, rendszeresen gyüjtöttem be mintaegyedeket a fajra történő meghatározásukhoz. (A csalétkeket egyébként is rendkívül alacsony egyedszámban látogató dolgozóik zavarását elkerülendő ugyanis erre a kísérletek alatt nem volt lehetőség.)

\section{P. nitens téli aktivitásának vizsgálata}

A P. nitens téli aktivitásának vizsgálatára 2012 decembere és 2013 márciusa között hét alkalommal került sor a füredi tölgyesben csalétkes és kiskvadrátos mintavételezés segítségével.

\footnotetext{
${ }^{2}$ A fogalmi zavar elkerülése végett a továbbiakban a csalétek megnevezést a csalilapnak és a rá kihelyezett csali(anyag) együttesének megjelölésére használom.
} 
A csalétkezés módja, a csalétkek száma, elhelyezése, stb. az előző fejezetben leírtakkal azonos volt, ill. azonos módon történt, azonban rövidebb, 5 órás (10:00-15:00) óránkénti felvételezésekkel (összesen: $1050=30$ csalétek $\times 5$ felvétel $\times 7$ nap). A talajfelszínen mozgó, táplálékkereső dolgozók aktivitását emellett három, véletlenszerüen kijelölt, egymástól kb. 15-15 m-re lévő $50 \mathrm{~cm} \times 50 \mathrm{~cm}$-es kiskvadrátban becsültem, amelyekben óránkénti három perces megfigyelésekkel regisztráltam az áthaladó egyedek számát, ill. adott esetben az általuk szállított zsákmányállat típusát (összesen: $105=3$ kiskvadrát $\times 5$ felvétel $\times 7$ nap). A csalétkes és kiskvadrátos felvételezésekkel párhuzamosan itt is óránkénti rögzítésre került mind a talajfelszíni-, mind pedig a talajhőmérséklet a fentebb már leírt módon.

\section{A. subterranea eszközhasználatának vizsgálata}

Az A. subterranea eszközhasználó viselkedését 2013 augusztusában négy alkalommal vizsgáltam csalétkes mintavételezés segítségével a litéri fenyvesben. A választás azért esett a nyár végi időszakra, mivel az eddigi adataim alapján az itt előforduló más hangyafajok jelentős részét ekkor már viszonylag alacsony aktivitás jellemzi, ezzel potenciálisan megteremtve az A. subterranea eszközhasználatának „zavarásmentes”, ugyanakkor mégis természetes körülmények között történő vizsgálatának körülményeit.

Csaliként porcukorral kevert virágmézet és petrolátumot használtam, amelyeknek adagolása, ill. a csalilapon való elhelyezése a csalétkes fejezetben leírtakkal azonos módon történt. A petrolátum (vazelin) egy színtelen, szagtalan, íztelen, gél állagú, ugyanakkor magasabb hőmérsékleten folyékonnyá váló szénhidrogén keverék, amelyet Banschbach és mtsai. (2006) vizsgálatának nyomán annak a kérdésnek a tesztelésére használtam, hogy vajon egy (fél)folyékony, ugyanakkor tápláléknak nem minősülő anyag is kiváltja-e a hasonló halmazállapotú táplálékforráson tapasztalt reakciókat és viselkedésformákat a kérdéses faj dolgozóiból.

Az egyes vizsgálatok alkalmával összesen 20, talajon elhelyezett csalétket használtam, amelyeket négy csoportban, véletlenszerüen helyeztem el, egymástól kb. 15-15 m-re. Minden egyes csalétekcsoport 5-5, egyenként kb. 3 m-es térközökkel elválasztott csalétekből állt. A felvételezések a reggeli órákban (az A. subterranea nappali aktivitásának csúcsán), 4 órán át (6:20-10:20) 20 perces idöközönként történtek 6:20-as kezdéssel, mintegy háromnegyed órával a csalétkek kihelyezése után (összesen: $960=20$ csalétek $\times 12$ felvétel $\times 4$ nap). A kb. 1 perces észlelések során minden egyes csalétken rögzítettem a látogató dolgozók 
egyedszámát, feljegyeztem ezek tartózkodási helyét, ill. az alábbi viselkedésformákat különítettem el: (1) a csalin táplálkozik ("eszik"); (2) különösebb tevékenység nélkül tartózkodik a csalétken ("jelen"); (3) „eszközt” hord rá a csalira ("hord"); (4) egy már előzőleg a csalira ráhordott „eszköz” helyzetét módosítja ("igazgat"); (5) egy már előzőleg a csalira ráhordott „eszközt” szállít el a csalétekről a fészek irányába ("szállít").

Hasonlóan az előző vizsgálatokhoz, a felvételezésekkel párhuzamosan mind a talajfelszíni, mind pedig a talajhőmérsékletet óránkénti rögzítésre került a fentebb már leírt módon.

\section{A. subterranea recéskabócákkal való asszociációjának vizsgálata}

A $R$. panzeri hangyákkal való asszociációját 5-5, egyenként $3 \mathrm{~m} \times 3 \mathrm{~m}$-es, véletlenszerüen elhelyezett kvadrátok segítségével vizsgáltam 2011 tavaszától őszéig öt alkalommal a füredi tölgyesben (összesen: 5 kvadrát $\times 5$ időszak $=225 \mathrm{~m}^{2}$ ). A kvadrátok területét, beleértve a talaj felsőbb rétegét, az avarréteget, a nagyobb, földre hullott korhadt faágakat, valamint a fák, cserjék gyökereit alaposan átvizsgálva térképeztem fel az itt fészkelő hangyakolóniákat, ill. a hangyákkal esetlegesen nem asszociáló kabócanimfákat. Minden egyes, kvadrátban regisztrált hangyakolónia esetében az alábbi paraméterek kerültek feljegyzésre: (1) a fészkelőhely típusa (kő alatt, talajban, avarban, faágakban, stb.); (2) a dolgozók/ivadékok hozzávetőleges száma, ill. a fészek kiterjedése alapján becsült relatív kolóniaméret (kis, közepes, nagy); (3) a kabócanimfák jelenléte/hiánya, jelenlét esetén ezek száma, a testnagyság (kicsi, közepes, nagy) alapján becsült fejlődési stádiuma, valamint a fészken belüli lokalizációja (perifériás részeken, bábkamrában, stb.); (4) a kabócanimfák számára potenciális táplálékul szolgáló, a kérdéses hangyafészket gyökereikkel átszövő fák és cserjék faji hovatartozása. A térképezéskor szándékosan figyelmen kívül hagytam az olyan speciálisabb fészkelőhelyeket, mint pl. a makktermések, gubacsok vagy üres csigaházak, amelyekben a kabócanimfák előfordulása (testméretük és életmódjuk ismeretében) valószínütlennek tünt, így a tipikus üregi fészkelő hangyafajok (pl. Temnothorax spp.) kolóniái kétségkívül alulreprezentálódtak a vizsgálat során.

Mivel a Reptalus-fajok megbízható azonosítása a hímivarszerv morfológiája alapján végezhető el (Holzinger és mtsai. 2003), a kabócákat faji szintig csupán azután lehetett meghatározni, miután sikerült a fészkekből való kirepülés előtt álló, kifejlett hím egyedeket is gyüjteni. 
Minthogy a fészkeik megnyitása túlságosan nagy zavarást jelentett a kolóniák számára, a hangyák kabócákkal való kölcsönhatásának közvetlen terepi vizsgálatára nem volt lehetőség. A problémát áthidalandó, a terepi vizsgálatot követően három alkalommal gyüjtöttem be A. subterranea kolóniatöredékeket a fészkükből származó, de a hangyáktól elszeparált kabócanimfákkal együtt. (Az A. subterranea választását a kabócáknak az ezzel a hangyafajjal történő majdnem kizárólagos asszociációja indokolta.) A begyüjtést követő néhány órán belül a kabócanimfákat Petri-csészébe helyeztem némi fészekanyaggal, ill. gyökérdarabokkal együtt, majd ezután egyesével hangyadolgozókat engedtem a nimfák közelébe és figyeltem mindkét fél reakcióját.

\subsection{Adatelemzés}

Fészkek denzitásának és términtázatának vizsgálata

A hangyafészkek términtázatának elemzéséhez a Clark-Evans-féle legközelebbi szomszéd analízis módszerét alkalmaztam (Clark és Evans 1954), amely a tapasztalt és a véletlenszerü eloszlás esetén várható átlagos legközelebbi szomszéd távolságok statisztikai összehasonlításán alapszik. A kettő hányadosa adja meg a legközelebbi szomszéd indexet $(R)$, amely 0 (maximális aggregáció) és 2,1491 (maximális egyenletesség) közötti értékeket vehet fel. Az $R$ index 1 körüli értéke esetén a términtázat véletlenszerű, míg az 1-nél szignifikánsabb kisebb értékei a fészkek aggregáltságát, a nagyobbak pedig a fészkek szegregáltságát jelzik.

A legközelebbi szomszéd analízist az abundánsabb (kvadrátonként $\geq 9$ fészekkel rendelkező) fajok fészkei mellett az egyes kvadrátokban regisztrált összes fészekre is elvégeztem. Az előbbiek esetében az $R$ indexet mind intraspecifikusan, a legközelebbi konspecifikus fészekszomszéd távolságokra, mind pedig a legközelebbi szomszédok identitásának (ti. hogy konspecifikus vagy heterospecifikus kolóniák-e) figyelmen kívül hagyásával vett fészektávolságokra kiszámoltam.

A szegélyhatás kiküszöbölése az ún. "wrap-around" korrekciós eljárás segítségével történt (Ripley 1979). Az elemzés során csak a már érett kolóniák fészkeit vettem figyelembe, tehát kizártam mindazon fészkeket, amelyekben még csupán a kolónialapítás kezdeti stádiumában lévő, dolgozók nélküli királynőt találtam. Szintén kizárásra kerültek azoknak a ritkább fajoknak a fészkei, amelyekből kvadrátonként csupán egy fordult elő. 
Annak eldöntésére, hogy az egyes fajok az azonos vagy az eltérő fajú kolóniák fészkeinek közelségét preferálják-e, ill. hogy ebben kimutatható-e szezonális különbség, mind a négy, tavasztól őszig tartó periódusban összehasonlítottam a legközelebbi konspecifikus és heterospecifikus fészekszomszéd távolságokat, valamint ezeket külön-külön az egyes időszakok között is. Ezeket az összehasonlításokat szintén mind az egyes, abundánsabb fajok fészkeire, mind pedig az egyes kvadrátokban regisztrált összes fészekre elvégeztem. Kivételt a fentiek alól a litéri fenyves jelentett, itt ugyanis az ősszel tapasztalt alacsony fészekdenzitás miatt az egyes fajok legközelebbi konspecifikus és heterospecifikus fészekszomszéd távolságainak összehasonlítására csupán a tavasztól nyár végéig tartó időszakban került sor.

A fészkek denzitása és términtázata közötti lehetséges kapcsolat megállapítására egyszerü lineáris regressziót végeztem, amelynek során a fészkek $\mathrm{m}^{2}$-ben kifejezett denzitásértékeit korreláltattam a legközelebbi konspecifikus fészekszomszéd távolságokra, ill. a legközelebbi fészekszomszéd távolságokra számolt $R$ index értékeivel.

Minthogy az alacsony mintaelemszám (3-3 kvadrát évszakonként) miatt a fészekdenzitás szezonális változásának statisztikai kiértékelésére nem nyílt lehetőség, így az eredmények értékelése során itt csupán az alapvető tendenciákat ismertettem.

\section{Csalétkes vizsgálatok}

A csalétkeket gyakrabban és nagyobb számban látogató fajpárok közötti, csalétkeken mutatott tér- és időbeli átfedés mértékének megállapításához null-modell analíziseket végeztem az EcoSim (7.71-es verzió) program (Gotelli és Entsminger 2004) segítségével.

Az időbeli (napi-, ill. szezonális) átfedés mértékének meghatározása a Renkonen-féle hasonlósági indexszel ${ }^{3}$ (Renkonen 1938) történt:

$$
I_{R}=1,0-0,5 \sum_{i=1}^{n}\left|p_{1 i}-p_{2 i}\right|=\sum_{i=1}^{n} \min \left(p_{1 i}, p_{2 i}\right)
$$

ahol $p_{1 i}$ és $p_{2 i}$ az első és második faj által az $i$-edik forrásból használt rész, azaz a csalétkek azon hányada, amelyen az adott faj az $i$-edik időpontban (órában/napon) jelen volt. A Renkonen-index egy szimmetrikus index, amely 0 (zéró átfedés) és 1 (teljes átfedés) közötti értékeket vehet fel. Amennyiben a kapott érték a random generált közösségekböl

\footnotetext{
${ }^{3}$ Gotelli és Entsminger (2004) nem teljesen pontosan a Czekanowski-index elnevezést használja Feisinger és mtsai. (1981) után.
} 
származókénál szignifikánsabb kisebb, az kismértékü átfedést (jelentős elkülönülést), míg ha nagyobb, az nagy átfedést (kismértékü elkülönülést) jelez az illető fajok napi-, ill. szezonális aktivitásában.

A térbeli átfedés, azaz a csalétkeken való együttes előfordulás mértékének meghatározása C-score analízis (Stone és Roberts 1990) segítségével történt, amely az ún. „sakktábla egységek” átlagos számát adja meg az egyes fajpárokra:

$$
S E=\left(r_{i}-S\right)\left(r_{j}-S\right)
$$

ahol $r_{i}$ az $i$-faj által elfoglalt csalétkek száma, $r_{j}$ a $j$-faj által elfoglalt csalétkek száma, $S$ pedig azon csalétkek száma, melyeken mindkét faj előfordult. Azon fajpárok esetében, amelyek mindig együtt fordulnak elő a csalétkeken a C-score értéke 0 lesz (maximális aggregáció), és minél erősebb a térbeli elkülönülés, annál nagyobb lesz a C-score értéke is. Szignifikáns az aggregáció, ha a kapott C-score érték a random generált közösségekböl származókénál szignifikánsabb kisebb, míg ha ezeknél nagyobb, az az illető fajok szegregálódását jelzi a csalétkeken.

A szezonális aktivitásban mutatott különbségek miatt az egyes fajpárok esetében a napi-, ill. térbeli átfedés mértékének meghatározása csupán azokra az időszakokra nézve történt meg, amikor az illető fajpáros mindkét tagja viszonylag nagyobb aktivitást mutatott.

A csalétkeket látogató gyakoribb fajok felfedező képességének összehasonlításához Fellers (1987) nyomán (kissé módosítva) az alábbiakat számoltam ki: (1) a látogatott csalétkek (amelyeken az illető faj megjelent) azon hányada, ahol az illető faj elsőként jelent meg; (2) a tartósan elfoglalt csalétkek (amelyeken az illető faj legalább az észlelések harmadában megfigyelhető volt) azon hányada, ahol az illető faj elsőként jelent meg; (3) a csalétkek felfedezési (tkp. az illető faj adott csalétken való első, órában kifejezett észlelési) ideje, függetlenül attól, hogy az illető faj az adott csalétken elsőként jelent meg vagy sem.

A táplálkozási hatékonyságot a táplálkozó egyedek és a csalétken tartózkodó összes egyed hányadosával jellemeztem, és külön-külön a kétféle táplálékforrásra nézve hasonlítottam össze az egyes gyakoribb fajpárok között.

A más fajokkal gyakrabban előforduló, ill. kölcsönható ( $\geq 10$ kizárással végződő interakcióban résztvevő) fajok interspecifikus interakcióinak összehasonlításához Fellers (1987), ill. Cerdá és mtsai. (1998a) nyomán (kissé módosítva) az alábbi kölcsönhatástípusokat különítettem el: (1) más faj(ok)/kolóniák egyedeivel való konfrontációmentes együttes jelenlét a csalétken ("koegzisztencia"); (2) a csalétekről való kizáráshoz nem vezető, 
kölcsönös agresszióval (pl. harccal) vagy azzal nem járó bármilyen agresszív megnyilvánulás (pl. harapás, méreg-/riasztóanyag kibocsátása, stb.) ("agresszió"); (3) egy másik faj/kolónia egyedének/egyedeinek kizárása a csalétekről passzív vagy agresszív módon ("kizárás"); (4) egy másik faj/kolónia egyedének/egyedeinek jelenléte vagy agresszív megnyilvánulása által kiváltott menekülés a csalétekről ("menekülés"). Az agresszív megnyilvánulások, kizárások és menekülések egy adott csalétken való túlreprezentálódását (pl. két idegen kolónia dolgozóinak tömeges összecsapásakor) elkerülendő, a fent elkülönített interakciók összegzésekor nem ezek tényleges számát, hanem azon egyperces megfigyelések számát vettem alapul, amelyeknél a kérdéses viselkedésformák megfigyelhetőek voltak.

A dominancia rangsorrendjének megállapításához a fent említett $(\geq 10$ kizárással végződő interakcióban résztvevő) fajok esetében az ún. dominancia indexet (Fellers 1987) használtam, amely azon interakciók gyakoriságát adja meg, amelyekből az illető faj „győztesként” került ki (tkp. a kizárások és az összes kizárással/meneküléssel járó interakció hányadosa).

A dominancia-hierarchiák linearitásának meghatározása a Landau-féle linearitási index (Landau 1951) segítségével történt:

$$
h=\frac{12}{n^{3}-n} \sum_{i=1}^{n}\left[v_{i}-\frac{n-1}{2}\right]^{2}
$$

ahol $n$ a fajszám, $v_{i}$ pedig azon fajok száma, amelyek felett az $i$-edik faj dominál. Az index értéke 0 és 1 közé esik, a 0 érték a tökéletesen körkörös hierarchiát, az 1 pedig a tökéletesen lineáris hierarchiát jelzi. Az egyes fajok lineáris hierarchiát legjobban közelítő rangsorba rendezését, valamint dominancia viszonyaik linearitásának tesztelését egy de Vries (1995, 1998) randomizációs eljárásán alapuló, Barta Zoltán (Debreceni Egyetem, Evolúciós Állattani és Humánbiológiai Tanszék) által írt C program segítségével végeztem el, amely a tapasztalati interakciós mátrixot egy sor véletlenszerüen generált mátrixszal összehasonlítva adja meg a torzítatlan Landau-index értékét ( $h$ ’), ill. ennek szignifikancia értékét.

\section{Felhasznált szoftverek}

A statisztikai elemzéseket, számolásokat, valamint az ábrákat a fentebb már említett szoftverek mellett Microsoft Excel 2007 (Microsoft Corporation, Redmond, WA, USA), SPSS Statistics (17.0.0-ás verzió), R (2.11.0-ás verzió) és PAST (2.17-es verzió) programok 
segítségével végeztem, ill. készítettem el. Az ábrák összefüzése, feliratozása, ill. egyéb utólagos szerkesztése Photoshop CS6 (13.0.1-es verzió) szoftverrel történt.

\subsection{Egyéb}

Gyakran használt rövidítések

A dolgozatban az egyes gyakoribb hangyafajok, valamint a fészekszomszéd távolságok jelölésére az alábbi rövidítéseket alkalmaztam: ApSu: Aphaenogaster subterranea; FoFu: Formica fusca; FoGa: Formica gagates; LaEm: Lasius emarginatus; PrNi: Prenolepis nitens; Te: Temnothorax spp.; LHSzT: legközelebbi heterospecifikus szomszéd távolságok; LKSzT: legközelebbi konspecifikus szomszéd távolságok; LSzT: legközelebbi szomszéd távolságok.

\section{Latin nevek}

Dolgozatomban a hangyák esetében a Hymenoptera Name Server (1.5-ös verzió) (Johnson 2007) adatbázisa alapján érvényben lévő latin nem- és fajneveket használtam.

Fényképek

A dolgozatban szereplő fényképek mindegyike saját készítésủ fotó (Sony DSC-H5 + Soligor makró előtétlencsék). 


\section{Eredmények}

4.1. Fészkek denzitásának és diszpergáltságának tér-idő mintázata

\section{Fajösszetétel}

A kvadrátos felvételezések során a füredi tölgyesben összesen 9 hangyafaj 427 fészkét sikerült regisztrálni (Függelék 1. táblázat). A legabundánsabb, leggyakoribb fajok a $P$. nitens és az A. subterranea voltak, amelyeknek fészkei együttesen az összfészekszám közel 80\%-át tették ki és az összes kvadrátban megtalálhatóak voltak (4. táblázat). A fészkek relatív abundanciája és gyakorisága között erős pozitív korreláció volt kimutatható (Spearman-féle korrelációs teszt, $\mathrm{r}=0,98 ; \mathrm{p}<0,001 ; \mathrm{n}=9$ ), azaz minél több fészekkel képviseltette magát egy adott faj, annál több kvadrátban voltak detektálhatóak a fészkei.

4. táblázat. A fészektérképezés során regisztrált hangyafajok relatív abundanciája és gyakorisága a két élőhelyen. A relatív abundancia itt az egyes fajok fészkeinek és az összfészekszámnak a hányadosát, míg a relatív gyakoriság azon kvadrátoknak az összkvadrátszámhoz viszonyított arányát jelenti, amelyben az illető faj fészke előfordult.

\begin{tabular}{lcccc}
\hline Fajok & \multicolumn{2}{c}{ Füredi tölgyes } & \multicolumn{2}{c}{ Litéri fenyves } \\
\cline { 2 - 5 } & $\begin{array}{c}\text { Relatív } \\
\text { abundancia }\end{array}$ & $\begin{array}{c}\text { Relatív } \\
\text { gyakoriság }\end{array}$ & $\begin{array}{c}\text { Relatív } \\
\text { abundancia }\end{array}$ & $\begin{array}{c}\text { Relatív } \\
\text { gyakoriság }\end{array}$ \\
Aphaenogaster subterranea & $\mathbf{0 , 3 3}$ & $\mathbf{1 , 0 0}$ & $\mathbf{0 , 2 3}$ & $\mathbf{1 , 0 0}$ \\
Camponotus aethiops & - & - & 0,003 & 0,08 \\
C. ligniperdus & - & - & 0,05 & 0,50 \\
Formica fusca & - & - & $\mathbf{0 , 1 4}$ & $\mathbf{0 , 8 3}$ \\
F. gagates & 0,01 & 0,33 & 0,01 & 0,08 \\
Lasius brunneus & 0,04 & 0,50 & - & - \\
L. emarginatus & 0,02 & 0,50 & $\mathbf{0 , 2 1}$ & $\mathbf{0 , 8 3}$ \\
L. myops & - & - & 0,01 & 0,08 \\
L. umbratus & - & - & 0,07 & 0,33 \\
Myrmecina graminicola & 0,02 & 0,42 & 0,02 & 0,42 \\
Myrmica sabuleti & - & - & 0,01 & 0,25 \\
Plagiolepis taurica & - & - & 0,01 & 0,17 \\
Ponera coarctata & 0,01 & 0,33 & 0,08 & 0,75 \\
Prenolepis nitens & $\mathbf{0 , 4 6}$ & $\mathbf{1 , 0 0}$ & - & - \\
Temnothorax crassispinus & 0,07 & 0,67 & 0,09 & 0,75 \\
T. parvulus & 0,05 & 0,67 & 0,02 & 0,25 \\
T. unifasciatus & - & - & 0,06 & $\mathbf{0 , 9 2}$ \\
\hline
\end{tabular}

A litéri fenyvesben végzett fészektérképezések során összesen 15 faj 351 fészke került elő (Függelék 2. táblázat). A legabundánsabb, leggyakoribb fajok az A. subterranea, ill. a L. emarginatus és a $F$. fusca voltak (4. táblázat). Bár a fészkek relatív abundanciája és gyakorisága itt is pozitívan korrelált egymással (Spearman-féle korrelációs teszt, r=0,90; 
p<0,001; n=15), rangsorrendjük a füredi tölgyeséhez képest kisebb mértékü egyezést mutatott (így pl. a T. unifasciatus fészkeinek relatív gyakorisága alapján másodikként, relatív abundanciája alapján viszont csupán hetediként rangsorolódott).

A két vizsgálati élöhelyen összesen 28 olyan fészket ${ }^{4}$ regisztráltam, amelyekben még csupán a kolónialapítás kezdeti stádiumában lévő, dolgozók nélküli királynőt találtam tojásokkal vagy azok nélkül (5. táblázat). Ezen királynőknek a többsége mindkét élőhelyen A. subterraneának bizonyult.

5. táblázat. A fészektérképezések során talált, még kezdeti stádiumban lévő kolóniák fészkei dolgozók nélküli királynővel (tojásokkal vagy azok nélkül) a két élőhelyen. ApSu: Aphaenogaster subterranea; CaLi: Camponotus ligniperdus; LaEm: Lasius emarginatus; MySa: Myrmica sabuleti; FoFu: Formica fusca; MyGr: Myrmecina graminicola; TeCr: Temnothorax crassispinus; TePa: Temnothorax parvulus; TeUn: Temnothorax unifasciatus.

\begin{tabular}{|c|c|c|c|c|c|c|c|c|c|}
\hline \multirow[b]{3}{*}{ Füredi tölgy } & \multicolumn{9}{|l|}{ Fajok } \\
\hline & $\mathrm{ApSu}$ & $\mathrm{CaLi}$ & LaEm & MySa & $\mathrm{FoFu}$ & MyGr & $\mathrm{TeCr}$ & TePa & TeUn \\
\hline & & & & & & & & & \\
\hline tavasz & - & - & - & - & - & - & - & 1 & - \\
\hline nyár eleje & 2 & - & - & - & - & - & - & - & - \\
\hline nyár vége & 2 & - & 2 & - & - & 1 & - & - & - \\
\hline ősz & 2 & - & - & - & - & - & 1 & - & - \\
\hline Litéri feny & & & & & & & & & \\
\hline tavasz & 2 & - & 1 & - & - & - & - & - & - \\
\hline nyár eleje & 1 & 2 & - & 2 & 1 & - & - & - & - \\
\hline nyár vége & 4 & - & - & - & - & - & - & - & - \\
\hline ösz & 1 & 2 & - & - & - & - & - & - & 1 \\
\hline
\end{tabular}

\section{Fészkek denzitása}

Mind az abundánsabb fajok fészkeinek denzitása, mind az összfészekdenzitás tavasztól őszig csökkenő tendenciát mutatott mindkét élőhelyen (5-6. ábrák). Két faj, a $P$. nitens és a L. emarginatus esetében azonban ettől eltérő trend volt megfigyelhető; előbbinél a fészkek denzitása a nyár eleji időszakban volt a legalacsonyabb, míg utóbbinál a fészekdenzitás éppen a nyár elején érte el maximumát.

\footnotetext{
4 Ezek természetesen még nem szó szoros értelemben vett fészkek, csupán potenciális fészkelőhelyek (tanyahelyek).
} 


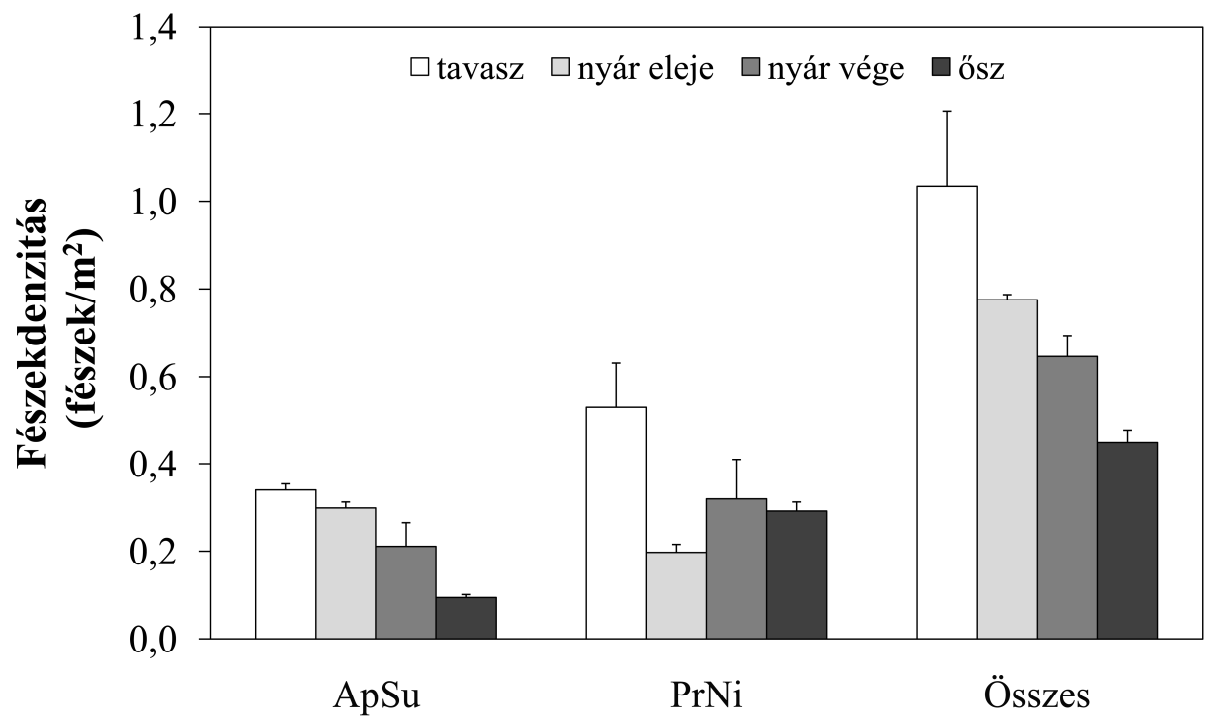

Fajok

5. ábra. A fészkek denzitásának szezonális változása a füredi tölgyesben. ApSu: Aphaenogaster subterranea; PrNi: Prenolepis nitens.

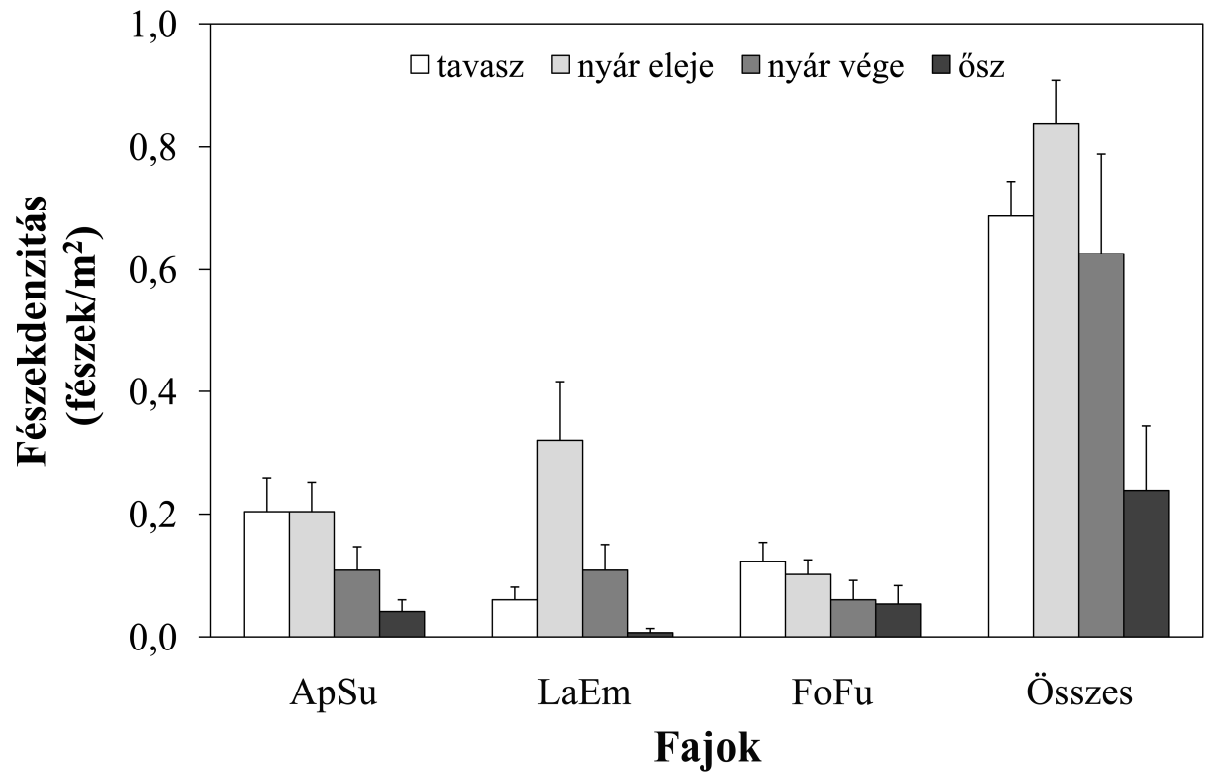

6. ábra. A fészkek denzitásának szezonális változása a litéri fenyvesben. ApSu: Aphaenogaster subterranea; LaEm: Lasius emarginatus; FoFu: Formica fusca.

\section{Fészkelöhelyek}

A füredi tölgyesben a fészkek döntő többsége, mintegy 75\%-a kövek alatt fordult elő, de relatíve nagy volt a makktermésekben, gubacsokban, csigaházakban, stb. előforduló fészkek aránya is a Temnothorax-fajok jelenléte miatt, amelyek itt elsődlegesen ezeket a speciálisabb fészkelőhelyeket részesítették előnyben (6. táblázat). A fészkelőhelyeik típusa alapján az egyes fajok összességében szignifikánsan különböztek egymástól (Khi-négyzet 
próba, $\left.\chi^{2}=520,47 ; \mathrm{df}=48 ; \mathrm{p}<0,001\right)$, ugyanakkor külön a két legabundánsabb faj, a $P$. nitens és az A. subterranea fészkelöhely preferenciája között nem volt kimutatható szignifikáns különbség $\left(\chi^{2}=10,78 ; \mathrm{df}=3 ; \mathrm{p}=0,15\right)$.

6. táblázat. A fészektérképezés során regisztrált hangyafajok fészkeinek száma a fészkelőhelyek típusai alapján a füredi tölgyesben.

\begin{tabular}{|c|c|c|c|c|c|c|c|}
\hline Fajok & $\begin{array}{c}\text { Kövek } \\
\text { alatt }\end{array}$ & $\begin{array}{c}\text { Talaj- } \\
\text { ban }\end{array}$ & $\begin{array}{c}\text { Avar- } \\
\text { ban }\end{array}$ & $\begin{array}{l}\text { Fagaly- } \\
\text { lyakban }\end{array}$ & $\begin{array}{c}\text { Faágak- } \\
\text { ban }^{2}\end{array}$ & $\begin{array}{l}\text { Fatön- } \\
\text { kökben }\end{array}$ & $\begin{array}{l}\text { Termé- } \\
\text { sekben, } \\
\text { stb. }\end{array}$ \\
\hline Aphaenogaster subterranea & 119 & 6 & 11 & 0 & 3 & 0 & 0 \\
\hline Formica gagates & 3 & 1 & 0 & 0 & 0 & 0 & 0 \\
\hline Lasius brunneus & 8 & 4 & 4 & 0 & 0 & 0 & 0 \\
\hline L. emarginatus & 3 & 2 & 1 & 0 & 1 & 1 & 0 \\
\hline Myrmecina graminicola & 7 & 0 & 0 & 0 & 0 & 0 & 0 \\
\hline Ponera coarctata & 3 & 0 & 0 & 0 & 0 & 0 & 1 \\
\hline Prenolepis nitens & 177 & 15 & 5 & 0 & 0 & 0 & 0 \\
\hline Temnothorax crassispinus & 2 & 0 & 0 & 4 & 0 & 0 & 25 \\
\hline T. parvulus & 0 & 0 & 0 & 1 & 0 & 0 & 20 \\
\hline Összesen: & 322 & 28 & 21 & 5 & 4 & 1 & 46 \\
\hline
\end{tabular}

${ }^{1}$ Vékonyabb, 1-2 cm-nél kisebb átmérőjü ágak.

${ }^{2}$ Vastagabb, 1-2 cm-nél nagyobb átméröjü ágak.

7. táblázat. A fészektérképezés során regisztrált hangyafajok fészkeinek száma a fészkelőhelyek típusai alapján a litéri fenyvesben.

\begin{tabular}{lccccccc}
\hline Fajok & $\begin{array}{c}\text { Kövek } \\
\text { alatt }\end{array}$ & $\begin{array}{c}\text { Talaj- } \\
\text { ban }\end{array}$ & $\begin{array}{c}\text { Avar- } \\
\text { ban }\end{array}$ & $\begin{array}{c}\text { Fagaly- } \\
\text { lyakban }{ }^{1}\end{array}$ & $\begin{array}{c}\text { Faágak- } \\
\text { ban }^{2}\end{array}$ & $\begin{array}{c}\text { Fatön- } \\
\text { kökben }\end{array}$ & $\begin{array}{c}\text { Termé- } \\
\text { sekben, } \\
\text { stb. }\end{array}$ \\
\cline { 2 - 8 } Aphaenogaster subterranea & 61 & 7 & 2 & 1 & 10 & 1 & 0 \\
Camponotus aethiops & 0 & 0 & 0 & 0 & 0 & 1 & 0 \\
C. ligniperdus & 7 & 2 & 2 & 0 & 3 & 2 & 0 \\
Formica fusca & 13 & 1 & 0 & 0 & 27 & 9 & 0 \\
F. gagates & 2 & 0 & 0 & 0 & 0 & 1 & 0 \\
Lasius emarginatus & 20 & 23 & 6 & 0 & 16 & 8 & 0 \\
L. myops & 4 & 0 & 0 & 0 & 0 & 0 & 0 \\
L. umbratus & 21 & 2 & 0 & 0 & 0 & 0 & 0 \\
Myrmecina graminicola & 8 & 0 & 0 & 0 & 0 & 0 & 0 \\
Myrmica sabuleti & 1 & 1 & 2 & 0 & 0 & 0 & 0 \\
Plagiolepis taurica & 2 & 0 & 0 & 0 & 0 & 0 & 0 \\
Ponera coarctata & 28 & 0 & 0 & 0 & 0 & 0 & 0 \\
Temnothorax crassispinus & 0 & 0 & 0 & 28 & 1 & 0 & 1 \\
T. parvulus & 0 & 0 & 0 & 3 & 3 & 0 & 0 \\
T. unifasciatus & 1 & 0 & 0 & 17 & 3 & 0 & 0 \\
\hline Összesen: & $\mathbf{1 6 8}$ & 36 & 12 & $\mathbf{4 9}$ & $\mathbf{6 3}$ & 22 & 1 \\
\hline Verk & & & & 0 & & 0 & 0 \\
\hline
\end{tabular}

${ }^{1}$ Vékonyabb, 1-2 cm-nél kisebb átméröjü ágak.

${ }^{2}$ Vastagabb, 1-2 cm-nél nagyobb átméröjủ ágak.

A litéri fenyvesben az előző élőhelyhez hasonlóan szintén a kövek alatt előforduló fészkek voltak a leggyakoribbak, 48\%-át kitéve az összes regisztrált fészeknek (7. táblázat). A füredi tölgyestől eltérően azonban itt viszonylag magas volt a különféle faanyagban talált 
fészkek száma is az ilyen jellegü fészkelőhelyeket preferáló fajok (pl. F. fusca, L. emarginatus), ill. részben szintén a Temnothorax-fajok jelenléte miatt, amelyeknek kolóniái a termések és gubacsok hiánya miatt ezen az élőhelyen fóként fagallyakban voltak megtalálhatóak. A fészkelőhelyeik típusa alapján az egyes fajok összességében itt is szignifikánsan különböztek egymástól (Khi-négyzet próba, $\chi^{2}=530,82 ; \mathrm{df}=84 ; \mathrm{p}<0,001$ ), és ugyancsak szignifikáns különbség volt kimutatható külön a három legabundánsabb faj, az A. subterranea, L. emarginatus és $F$. fusca fészkelöhely preferenciájában is ( $\chi^{2}=84,92 ; \mathrm{df}=10$; $\mathrm{p}<0,001)$.

8. táblázat. A hangyafészkek términtázata a füredi tölgyesben a legközelebbi szomszéd analízis módszere (Clark és Evans 1954) alapján. n: fészekszám; $\mathrm{R}_{\mathrm{LKSz} \mathrm{T}}$ : a legközelebbi szomszéd index a legközelebbi konspecifikus szomszéd távolságokra (LKSzT); $\mathrm{R}_{\mathrm{LSz} \mathrm{T}}$ : a legközelebbi szomszéd index a legközelebbi szomszéd távolságokra (LSzT). Az 1-nél szignifikánsabb kisebb értékek a fészkek aggregáltságát, az 1-nél szignifikánsan nagyobb értékek pedig a fészkek szegregáltságát jelzik.

\begin{tabular}{|c|c|c|c|c|c|}
\hline Időszak & Kvadrát & Fészkek & $\mathrm{n}$ & $\mathrm{R}_{\mathrm{LKSzT}}$ & $\mathrm{R}_{\mathrm{LSzT}}$ \\
\hline \multirow[t]{9}{*}{ Tavasz } & \multirow[t]{3}{*}{ I. } & A. subterranea & 16 & $1,40 * *$ & 0,92 n.sz. \\
\hline & & P. nitens & 17 & 1,03 & 0,79 n.sz. \\
\hline & & összes fészek & 34 & - & $1,21^{*}$ \\
\hline & \multirow[t]{3}{*}{ II. } & A. subterranea & 18 & 0,99 & $\mathbf{0 , 5 5}$ *** \\
\hline & & P. nitens & 34 & $1,26^{* *}$ & 0,85 n.sz. \\
\hline & & összes fészek & 61 & - & 1,06 n.sz. \\
\hline & \multirow[t]{3}{*}{ III. } & A. subterranea & 16 & 1,11 n.sz. & $0,62 * *$ \\
\hline & & P. nitens & 27 & $1,24 *$ & 0,88 n.sz. \\
\hline & & összes fészek & 57 & - & $1,16^{*}$ \\
\hline \multirow[t]{8}{*}{ Nyár eleje } & \multirow[t]{3}{*}{ I. } & A. subterranea & 14 & $1,30 *$ & $\mathbf{0 , 5 8 * *}$ \\
\hline & & P. nitens & 10 & 1,06 n.sz. & $\mathbf{0 , 5 6 * *}$ \\
\hline & & összes fészek & 37 & - & 1,09 n.sz. \\
\hline & \multirow[t]{3}{*}{ II. } & A. subterranea & 14 & 1,07 n.sz. & $0,57 * *$ \\
\hline & & P. nitens & 11 & 1,00 n.sz. & $0,37 * * *$ \\
\hline & & összes fészek & 39 & - & $0,79 *$ \\
\hline & \multirow[t]{2}{*}{ III. } & A. subterranea & 16 & 1,01 n.sz. & $0,70^{*}$ \\
\hline & & összes fészek & 38 & - & 1,03 n.sz. \\
\hline \multirow[t]{8}{*}{ Nyár vége } & \multirow[t]{3}{*}{ I. } & A. subterranea & 10 & 0,92 n.sz. & $\mathbf{0 , 5 1} * *$ \\
\hline & & P. nitens & 14 & 1,14 n.sz. & $0,68 *$ \\
\hline & & összes fészek & 28 & - & 0,95 n.sz. \\
\hline & \multirow[t]{3}{*}{ II. } & A. subterranea & 15 & 1,20 n.sz. & $0,81 \mathrm{n} . \mathrm{sz}$. \\
\hline & & P. nitens & 9 & $1,52 * *$ & 0,67 n.sz. \\
\hline & & összes fészek & 31 & - & 1,18 n.sz. \\
\hline & \multirow[t]{2}{*}{ III. } & P. nitens & 24 & 0,93 n.sz. & 0,81 n.sz. \\
\hline & & összes fészek & 36 & - & 0,96 n.sz. \\
\hline \multirow[t]{5}{*}{ Ösz } & I. & összes fészek & 12 & - & 0,78 n.sz. \\
\hline & \multirow[t]{2}{*}{ II. } & P. nitens & 19 & 1,00 n.sz. & 0,82 n.sz. \\
\hline & & összes fészek & 26 & - & 0,90 n.sz. \\
\hline & \multirow[t]{2}{*}{ III. } & P. nitens & 18 & 1,17 n.sz. & 0,87 n.sz. \\
\hline & & összes fészek & 28 & - & 1,11 n.sz. \\
\hline
\end{tabular}

t-próba: n.sz. $0,05<$ p; $* 0,01<\mathrm{p}<0,05 ; * * 0,001<\mathrm{p}<0,01 ; * * * \mathrm{p}<0,001$ 
A füredi tölgyesben mind a $P$. nitens, mind az A. subterranea fészkei többnyire véletlenszerü diszpergáltságot mutattak (8. táblázat). Szegregált términtázat az előbbi faj fészkeit csupán három esetben, tavasszal és nyár végén, míg az utóbbiéit egy-egy esetben, tavasszal és nyár elején jellemezte. Mindkét faj, de különösképp az A. subterranea fészkei ugyanakkor több esetben nagyfokú aggregációt mutattak, amikor az elemzés során a legközelebbi szomszédok identitása (ti. hogy konspecifikus vagy heterospecifikus kolóniák-e) figyelmen kívül lett hagyva. Az intraspecifikus términtázatokhoz hasonlóan az egyes kvadrátokban regisztrált összes fészek diszpergáltsága is többnyire véletlenszerünek bizonyult.

9. táblázat. A hangyafészkek términtázata a litéri fenyvesben a legközelebbi szomszéd analízis módszere (Clark és Evans 1954) alapján. n: fészekszám; $\mathrm{R}_{\mathrm{LKSzT}}$ : a legközelebbi szomszéd index a legközelebbi konspecifikus szomszéd távolságokra (LKSzT); $\mathrm{R}_{\mathrm{LSz} \mathrm{T}}$ : a legközelebbi szomszéd index a legközelebbi szomszéd távolságokra (LSzT). Az 1-nél szignifikánsabb kisebb értékek a fészkek aggregáltságát, az 1-nél szignifikánsan nagyobb értékek pedig a fészkek szegregáltságát jelzik.

\begin{tabular}{|c|c|c|c|c|c|}
\hline Időszak & Kvadrát & Fészkek & $\mathrm{n}$ & $\mathrm{R}_{\mathrm{LKSzT}}$ & $\mathrm{R}_{\mathrm{LSzT}}$ \\
\hline \multirow[t]{6}{*}{ Tavasz } & \multirow[t]{3}{*}{ I. } & A. subterranea & 9 & 0,93 n.sz. & $0,57 *$ \\
\hline & & F. fusca & 9 & 1,29 n.sz. & $0,64 *$ \\
\hline & & összes fészek & 32 & - & 1,02 n.sz. \\
\hline & II. & összes fészek & 30 & - & 1,13 n.sz. \\
\hline & \multirow[t]{2}{*}{ III. } & A. subterranea & 15 & 1,07 n.sz. & $\mathbf{0 , 5 9} * *$ \\
\hline & & összes fészek & 39 & - & 0,97 n.sz. \\
\hline \multirow[t]{8}{*}{ Nyár eleje } & \multirow[t]{3}{*}{ I. } & A. subterranea & 14 & $\mathbf{0 , 7 0}$ * & $\mathbf{0 , 5 3} * * *$ \\
\hline & & L. emarginatus & 10 & 0,74 n.sz. & $\mathbf{0 , 5 7} * *$ \\
\hline & & összes fészek & 41 & - & 1,01 n.sz. \\
\hline & \multirow[t]{2}{*}{ II. } & L. emarginatus & 12 & 0,87 n.sz. & 0,72 n.sz. \\
\hline & & összes fészek & 35 & - & $1,25 * *$ \\
\hline & \multirow[t]{3}{*}{ III. } & A. subterranea & 10 & 0,92 n.sz. & $\mathbf{0 , 4 5} * * *$ \\
\hline & & L. emarginatus & 25 & 0,96 n.sz. & $\mathbf{0 , 7 5} *$ \\
\hline & & összes fészek & 47 & - & 0,99 n.sz. \\
\hline \multirow[t]{6}{*}{ Nyár vége } & \multirow[t]{2}{*}{ I. } & A. subterranea & 9 & 1,04 n.sz. & $0,55^{*}$ \\
\hline & & összes fészek & 36 & - & 0,91 n.sz. \\
\hline & \multirow[t]{3}{*}{ II. } & L. emarginatus & 9 & $\mathbf{0 , 5 9} *$ & $\mathbf{0 , 3 3} * * *$ \\
\hline & & L. umbratus & 13 & 0,76 n.sz. & $\mathbf{0 , 4 7} * * *$ \\
\hline & & összes fészek & 41 & - & 0,91 n.sz. \\
\hline & III. & összes fészek & 15 & - & 0,86 n.sz. \\
\hline \multirow[t]{2}{*}{ Ösz } & I. & összes fészek & 11 & - & 1,09 n.sz. \\
\hline & III. & összes fészek & 21 & - & 0,86 n.sz. \\
\hline
\end{tabular}

t-próba: n.sz. $0,05<\mathrm{p} ; * 0,01<\mathrm{p}<0,05 ; * * 0,001<\mathrm{p}<0,01 ; * * * \mathrm{p}<0,001$ 
Az előző élőhelyhez hasonlóan a litéri fenyvesben az egyes fajok fészkei intraspecifikusan többnyire véletlenszerü diszpergáltságot, a legközelebbi szomszédok identitásának figyelmen kívül hagyása esetén pedig szignifikáns aggregációt mutattak (9. táblázat). A legtöbb esetben hasonlóképpen véletlenszerünek bizonyult az egyes kvadrátokban regisztrált összes fészek términtázata is.

Szignifikáns pozitív korreláció a fészkek denzitása és térbeli eloszlásának egyenletessége között egyedül a $P$. nitens esetében volt kimutatható (10. táblázat).

10. táblázat. A lineáris korrelációs koefficiens (r) értékei a fészekdenzitás (D) és a legközelebbi konspecifikus szomszéd távolságokra (LKSzT), ill. a legközelebbi szomszéd távolságokra (LSzT) számolt Clark-Evans-féle legközelebbi szomszéd index (R) értékei között az abundánsabb fajok fészkei és az összes fészek esetén a két élőhelyen. n: mintaelemszám.

\begin{tabular}{lccc}
\hline Fészkek & $\mathrm{r}\left(\mathrm{D}-\mathrm{R}_{\mathrm{LKSzT}}\right)$ & $\mathrm{r}\left(\mathrm{D}-\mathrm{R}_{\mathrm{LSzT}}\right)$ & $\mathrm{n}$ \\
Aphaenogaster subterranea (füredi tölgyes) & 0,26 & 0,37 & 8 \\
A. subterranea (litéri fenyves) & $-0,21$ & 0,30 & 5 \\
Prenolepis nitens (füredi tölgyes) & $-0,03$ & $0,72^{*}$ & 10 \\
összes fészek (füredi tölgyes) & - & 0,43 & 12 \\
összes fészek (litéri fenyves) & - & 0,07 & 11 \\
\hline
\end{tabular}

n.sz. $0,05<\mathrm{p} ; * 0,01<\mathrm{p}<0,05 ; * * 0,001<\mathrm{p}<0,01 ; * * * \mathrm{p}<0,001$

\section{Legközelebbi fészekszomszédok}

A füredi tölgyesben az A. subterranea fészkeinek legközelebbi heterospecifikus szomszéd távolságai minden évszakban szignifikánsan kisebbnek bizonyultak a legközelebbi konspecifikus szomszéd távolságoknál (Wilcoxon-féle előjeles rangpróba, tavasz: z=-4,42; $\mathrm{p}<0,001 ; \mathrm{n}=50$; nyár eleje: $\mathrm{z}=-4,05 ; \mathrm{p}<0,001 ; \mathrm{n}=44$; nyár vége: $\mathrm{z}=-3,40 ; \mathrm{p}<0,001 ; \mathrm{n}=31$; ősz: $\mathrm{z}=-3,23 ; \mathrm{p}<0,001 ; \mathrm{n}=14$ ), és egyúttal viszonylag konstansak is maradtak az évad során (Kruskal-Wallis próba, $\chi^{2}=1,89 ; \mathrm{df}=3 ; \mathrm{p}=0,60$ ), míg ezzel szemben a legközelebbi konspecifikus fészekszomszéd távolságok szignifikáns szezonális változást mutattak $\left(\chi^{2}=24,61 ; \mathrm{df}=3 ; \mathrm{p}<0,001\right)(7$. ábra $)$.

Az A. subterraneától eltérően a $P$. nitens fészkeinek legközelebbi heterospecifikus szomszéd távolságai csupán az évad első felében voltak szignifikánsan kisebbek a legközelebbi konspecifikus szomszéd távolságoknál, az évad második felében azonban már nem volt kimutatható szignifikáns különbség közöttük (Wilcoxon-féle elöjeles rangpróba, tavasz: $\mathrm{z}=-3,05 ; \mathrm{p}<0,01 ; \mathrm{n}=78$; nyár eleje: $\mathrm{z}=-2,71 ; \mathrm{p}<0,01 ; \mathrm{n}=29$; nyár vége: $\mathrm{z}=-0,48 ; \mathrm{p}=0,63$; $\mathrm{n}=47 ;$ ősz: $\mathrm{z}=-0,15 ; \mathrm{p}=0,88 ; \mathrm{n}=43$ ) (7. ábra). Míg a legközelebbi heterospecifikus fészekszomszéd távolságokat szignifikáns szezonális változás jellemezte (Kruskal-Wallis 
próba, $\left.\chi^{2}=15,86 ; \mathrm{df}=3 ; \mathrm{p}<0,01\right)$, addig a legközelebbi konspecifikus fészekszomszéd távolságok nem fluktuáltak jelentősen az évad során $\left(\chi^{2}=5,15 ; \mathrm{df}=3 ; \mathrm{p}=0,16\right)$.
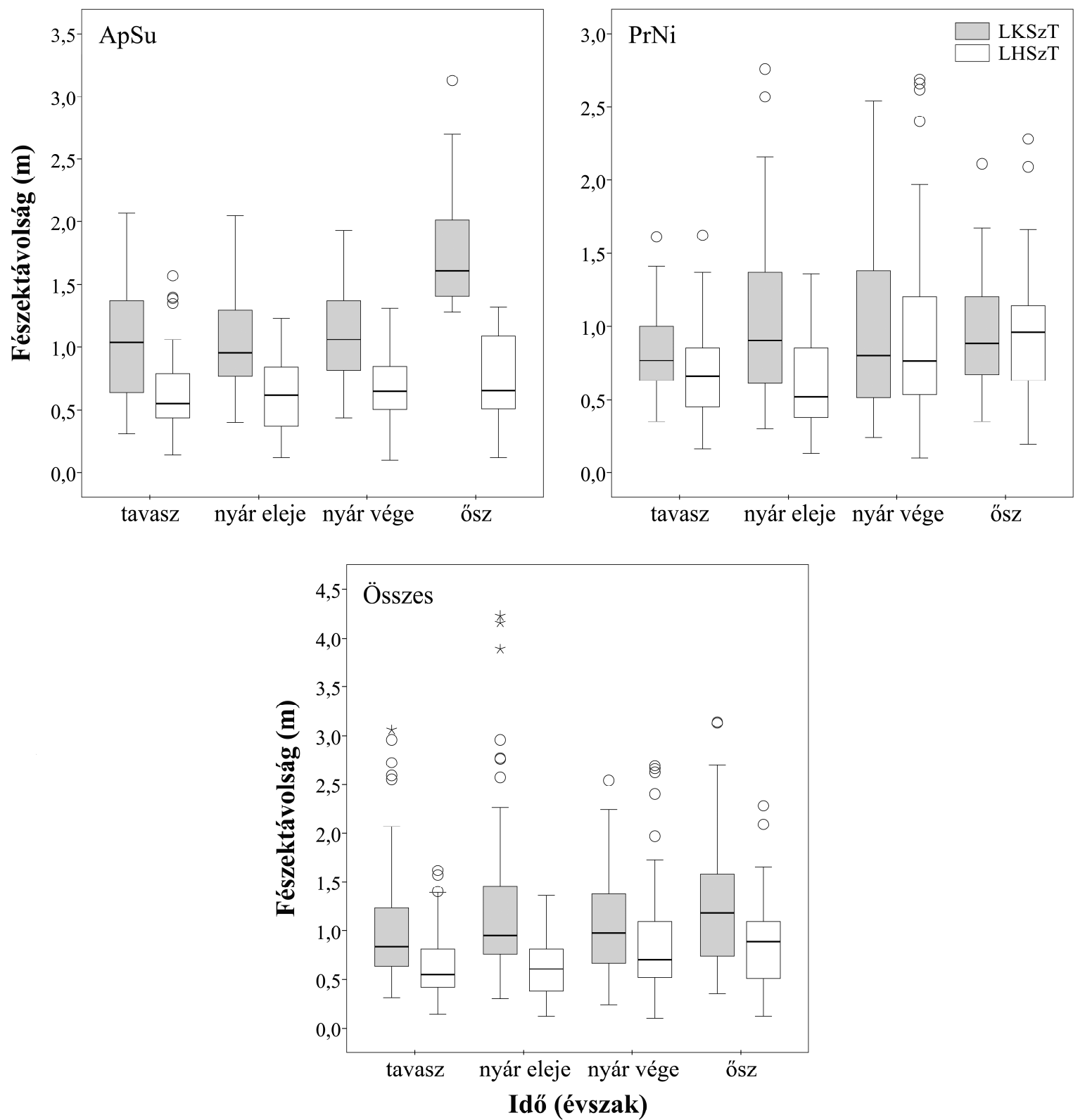

7. ábra. A legközelebbi fészekszomszéd távolságok összehasonlítása a füredi tölgyesben. A boxok az interkvartilis tartományt, a boxokban lévő vízszintes vonalak a mediánokat, a talpak az interkvartilis tartomány 1,5-szereseit, az üres körök és csillagok pedig a kiugró-, ill. az extrém kiugró értékeket jelölik. ApSu: Aphaenogaster subterranea; PrNi: Prenolepis nitens; LKSzT: legközelebbi konspecifikus szomszéd távolságok; LHSzT: legközelebbi heterospecifikus szomszéd távolságok.

Az egyes kvadrátokban regisztrált összes fészek esetében a legközelebbi heterospecifikus szomszéd távolságok minden évszakban szignifikánsan kisebbek voltak a legközelebbi konspecifikus szomszéd távolságoknál (Wilcoxon-féle elöjeles rangpróba, tavasz: $\mathrm{z}=-6,52 ; \mathrm{p}<0,001 ; \mathrm{n}=145$; nyár eleje: $\mathrm{z}=-6,90 ; \mathrm{p}<0,001 ; \mathrm{n}=111$; nyár vége: $\mathrm{z}=-2,90$; 
$\mathrm{p}<0,01 ; \mathrm{n}=88$; ősz: $\mathrm{z}=-3,21 ; \mathrm{p}<0,01 ; \mathrm{n}=63)$, és mind elöbbiek, mind utóbbiak szignifikáns szezonális változást mutattak az évad során (Kruskal-Wallis próba, LKSzT: $\chi^{2}=11,68$; df=3; p<0,01; LHSzT: $\left.\chi^{2}=21,60 ; d f=3 ; p<0,001\right)$ (7. ábra).

A legközelebbi fészekszomszédok identitása összességében szignifikánsan különbözött a véletlenszerütől (Khi-négyzet próba, $\chi^{2}=109,77$; df=64; p<0,05) (Függelék 3. táblázat). Pozitív interspecifikus asszociációt az A. subterranea-T. parvulus és a T. parvulusL. brunneus, míg negatív interspecifikus asszociációt az A. subterranea-L. emarginatus és a P. nitens-T. parvulus fajpárok kolóniái mutattak, azaz előbbiek a vártnál nagyobb, utóbbiak pedig a vártnál kisebb gyakorisággal fordultak elö egymás közvetlen szomszédságában. Pozitív intraspecifikus asszociáció a L. emarginatus kolóniáit jellemezte, míg az A. subterranea és a T. crassispinus fajok kolóniái között negatív intraspecifikus asszociáció volt megfigyelhető.

A litéri fenyvesben az A. subterranea fészkeinek legközelebbi heterospecifikus szomszéd távolságai tavasszal és nyár végén szignifikánsan kisebbek voltak a legközelebbi konspecifikus szomszéd távolságoknál, míg ezzel szemben nyár elején nem volt kimutatható szignifikáns különbség közöttük (Wilcoxon-féle előjeles rangpróba, tavasz: $z=-4,02 ; p<0,001$; $\mathrm{n}=30$; nyár eleje: $\mathrm{z}=-0,63 ; \mathrm{p}=0,53 ; \mathrm{n}=30$; nyár vége: $\mathrm{z}=-2,90 ; \mathrm{p}<0,01 ; \mathrm{n}=16$ ) (8. ábra). Szignifikáns szezonális változás csupán a legközelebbi konspecifikus fészekszomszéd távolságokat jellemezte, a legközelebbi heterospecifikus fészekszomszéd távolságok ellenben viszonylag konstansak maradtak az évad során (Kruskal-Wallis próba, LKSzT: $\chi^{2}=17,73$; $\mathrm{df}=2 ; \mathrm{p}<0,001 ;$ LHSzT: $\left.\chi^{2}=0,49 ; \mathrm{df}=2 ; \mathrm{p}=0,78\right)$.

Az A. subterraneához hasonlóan a L. emarginatus fészkeinek legközelebbi heterospecifikus szomszéd távolságai tavasszal és nyár végén a legközelebbi konspecifikus szomszéd távolságoknál szignifikánsan kisebbnek bizonyultak, míg nyár elején szintúgy nem volt kimutatható szignifikáns különbség közöttük (Wilcoxon-féle előjeles rangpróba, tavasz: $\mathrm{z}=-2,67 ; \mathrm{p}<0,01 ; \mathrm{n}=9$; nyár eleje: $\mathrm{z}=-0,79 ; \mathrm{p}=0,43 ; \mathrm{n}=47$; nyár vége: $\mathrm{z}=-2,10 ; \mathrm{p}<0,05 ; \mathrm{n}=16$ ) (8. ábra). Az évad során mind a legközelebbi konspecifikus fészekszomszéd távolságok, mind a legközelebbi heterospecifikus fészekszomszéd távolságok szignifikáns szezonális változást mutattak (Kruskal-Wallis próba, LKSzT: $\chi^{2}=18,40 ; \mathrm{df}=2$; $\mathrm{p}<0,001$; LHSzT: $\chi^{2}=13,78$; df=2; $\mathrm{p}<0,01)$.

A F. fusca fészkeinek legközelebbi heterospecifikus szomszéd távolságai mind a három évszakban szignifikánsan kisebbek voltak a legközelebbi konspecifikus szomszéd távolságoknál (Wilcoxon-féle előjeles rangpróba, tavasz: $\mathrm{z}=-3,43 ; \mathrm{p}<0,001 ; \mathrm{n}=18$; nyár eleje: $\mathrm{z}=-2,96 ; \mathrm{p}<0,01 ; \mathrm{n}=15$; nyár vége: $\mathrm{z}=-2,67 ; \mathrm{p}<0,01 ; \mathrm{n}=9$ ), ugyanakkor sem előbbiek, sem 
utóbbiak nem fluktuáltak jelentősen az évad során (Kruskal-Wallis próba, LKSzT: $\chi^{2}=4,92$; $\mathrm{df}=2 ; \mathrm{p}=0,09 ;$ LHSzT: $\left.\chi^{2}=5,10 ; \mathrm{df}=2 ; \mathrm{p}=0,08\right)$ (8. ábra).

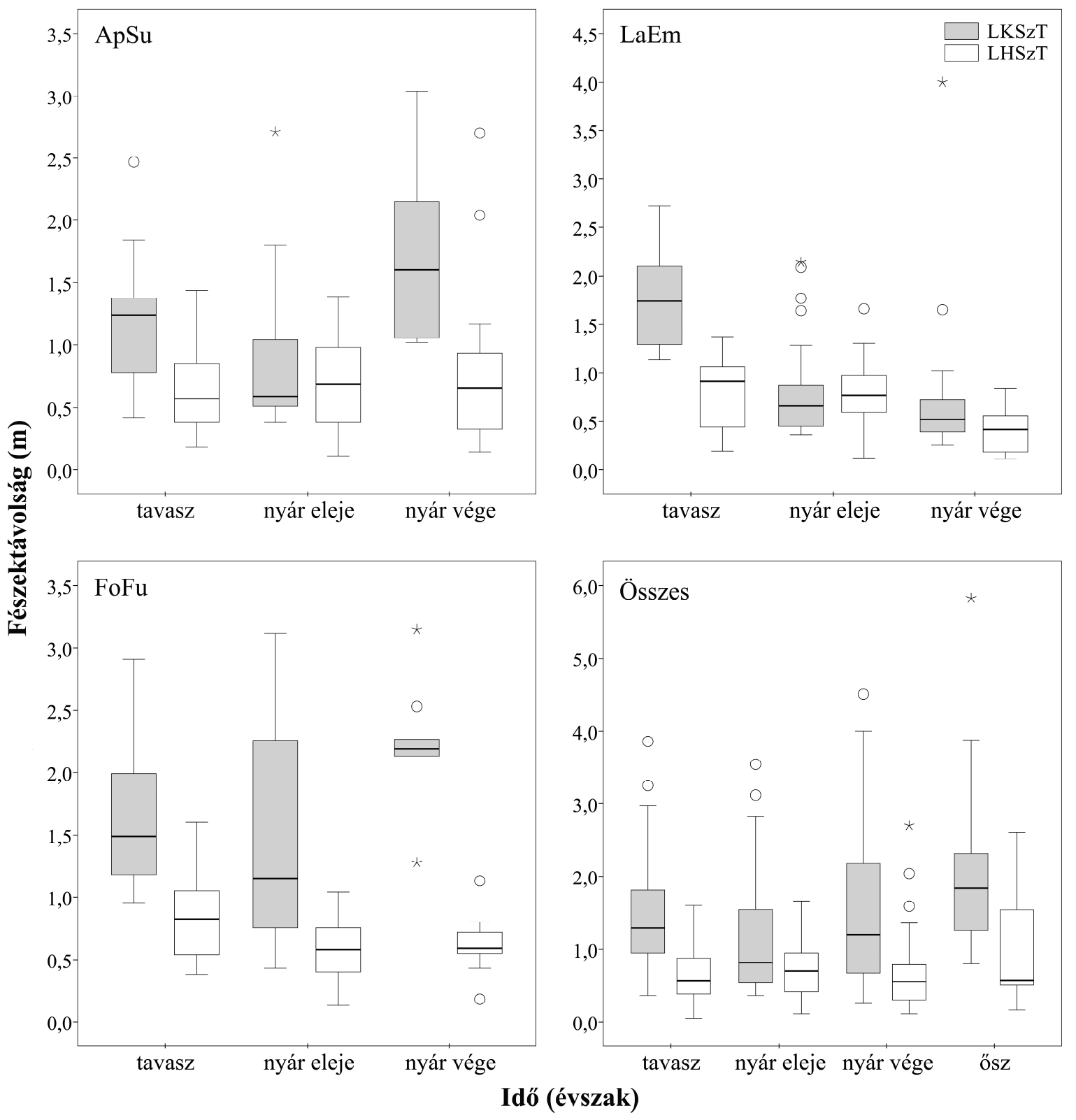

8. ábra. A legközelebbi fészekszomszéd távolságok összehasonlítása a litéri fenyvesben. A boxok az interkvartilis tartományt, a boxokban lévő vízszintes vonalak a mediánokat, a talpak az interkvartilis tartomány 1,5-szereseit, az üres körök és csillagok pedig a kiugró-, ill. az extrém kiugró értékeket jelölik. ApSu: Aphaenogaster subterranea; LaEm: Lasius emarginatus; FoFu: Formica fusca; LKSzT: legközelebbi konspecifikus szomszéd távolságok; LHSzT: legközelebbi heterospecifikus szomszéd távolságok.

$\mathrm{Az}$ egyes kvadrátokban regisztrált összes fészek esetében, hasonlóan a füredi tölgyeshez, a heterospecifikus szomszéd távolságok minden évszakban szignifikánsan kisebbnek bizonyultak a legközelebbi konspecifikus szomszéd távolságoknál (Wilcoxon-féle elöjeles rangpróba, tavasz: $\mathrm{z}=-8,02 ; \mathrm{p}<0,001 ; \mathrm{n}=98$; nyár eleje: $\mathrm{z}=-3,83 ; \mathrm{p}<0,001 ; \mathrm{n}=115$; nyár 
vége: $z=-6,69 ; p<0,001 ; n=86$; ősz: $z=-3,74 ; p<0,001 ; n=28)$, és az évad során mind előbbiek, mind utóbbiak esetében szignifikáns szezonális változás lehetett kimutatni (Kruskal-Wallis próba, LKSzT: $\chi^{2}=34,86 ; \mathrm{df}=3 ; \mathrm{p}<0,001 ;$ LHSzT: $\left.\chi^{2}=9,61 ; \mathrm{df}=3 ; \mathrm{p}<0,05\right)$ (8. ábra).

A legközelebbi fészekszomszédok identitása az előző élőhelyhez hasonlóan összességében itt is szignifikánsan különbözött a véletlenszerütől (Khi-négyzet próba, $\left.\chi^{2}=463,89 ; \mathrm{df}=196 ; \mathrm{p}<0,01\right)$ (Függelék 4. táblázat). Pozitív interspecifikus asszociáció az A. subterranea-C. ligniperdus, $F$. fusca- $P$. coarctata, $T$. crassispinus- $F$. fusca, T. parvulusF. fusca, T. crassispinus-C. ligniperdus, T. unifasciatus-L. emarginatus, P. coarctataM. graminicola, ill. a $P$. coarctata-M. sabuleti fajpárok kolóniái között, míg negatív interspecifikus asszociáció az A. subterranea-T. crassispinus, L. emarginatus-A. subterranea, F. fusca-C. ligniperdus, T. crassispinus-T. unifasciatus, L. umbratus-F. fusca, valamint a M. graminicola-L. emarginatus fajok között volt megfigyelhető. A fentiek közül három fajpáros, az A. subterranea-C. ligniperdus, P. coarctata-M. graminicola, ill. a F. fuscaC. ligniperdus kolóniáinak viszonyát kétirányú, elöbbiek esetében kölcsönösen pozitív, míg utóbbinál kölcsönösen negatív asszociáció jellemezte. Pozitív intraspecifikus asszociációt két Lasius-faj, a L. emarginatus és a L. umbratus kolóniái, míg negatív intraspecifikus asszociációt a T. unifasciatus kolóniái mutattak.

\subsection{Táplálékszerzés tér-idő mintázata}

\section{Fajösszetétel}

A füredi tölgyesben végzett csalétkezések során 12 hangyafaj több mint 100 ezer egyedét sikerült regisztrálni, amelyek közül a legabundánsabb (legnagyobb egyedszámmal előforduló) és leggyakoribb (legtöbb csalétket elfoglaló) faj a $P$. nitens volt (9. ábra, Függelék 5. táblázat).

A litéri fenyvesben a csalétkes vizsgálatok során 13 faj közel 20 ezer egyede került felvételezésre. Ezek közül a legabundánsabb faj az A. subterranea, míg a leggyakoribb a F. fusca volt (10. ábra, Függelék 6. táblázat). 


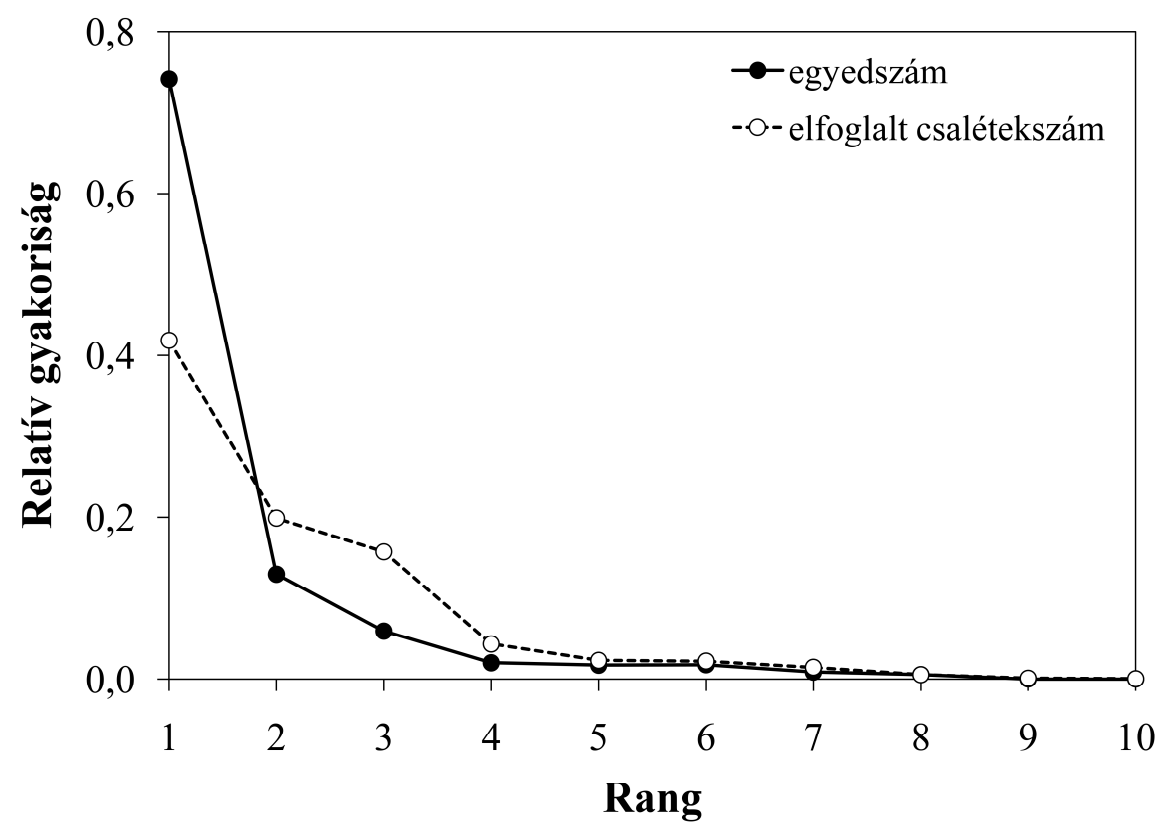

9. ábra. A csalétkeken regisztrált egyedszámok és az elfoglalt csalétkek számának relatív gyakorisága alapján vett rangsorrendek a füredi tölgyesben. /Egyedszám/: 1. Prenolepis nitens; 2. Aphaenogaster subterranea; 3. Liometopum microcephalum; 4. Lasius brunneus; 5. Crematogaster schmidti; 6. Temnothorax spp.; 7. Formica gagates; 8. Lasius emarginatus; 9. Camponotus fallax; 10. Camponotus truncatus. /Elfoglalt csalétekszám/: 1. P. nitens; 2. A. subterranea; 3. Temnothorax spp.; 4. F. gagates; 5. L. brunneus; 6. L. microcephalum; 7. C. schmidti; 8. L. emarginatus; 9. C. fallax; 10. C. truncatus.

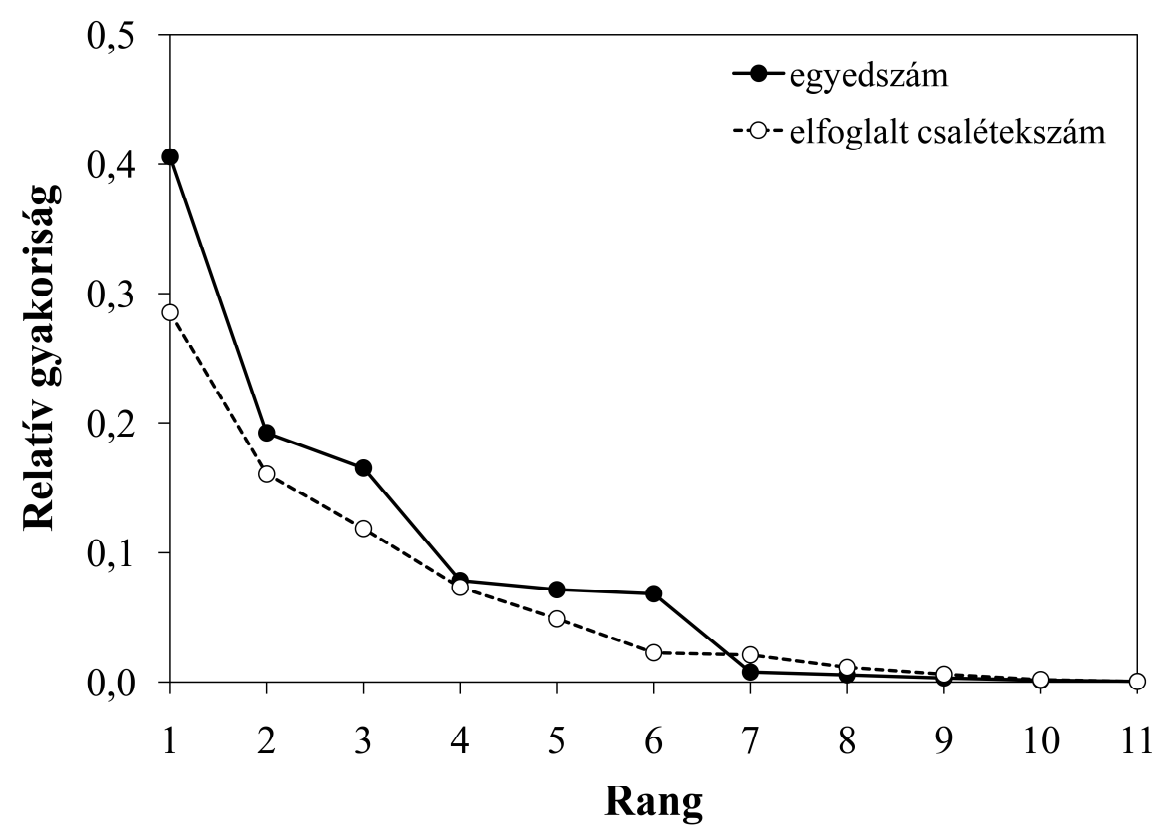

10. ábra. A csalétkeken regisztrált egyedszámok és az elfoglalt csalétkek számának relatív gyakorisága alapján vett rangsorrendek a litéri fenyvesben. /Egyedszám/: 1. Aphaenogaster subterranea; 2. Lasius emarginatus; 3. Formica fusca; 4. Formica gagates; 5. Temnothorax spp.; 6. Myrmica sabuleti; 7. Camponotus ligniperdus; 8. Formica pratensis; 9. Plagiolepis taurica; 10. Camponotus fallax; 11. Myrmica schencki. /Elfoglalt csalétekszám/: 1. F. fusca; 2. A. subterranea; 3. Temnothorax spp.; 4. L. emarginatus; 5. F. gagates; 6. C. ligniperdus; 7. M. sabuleti; 8. F. pratensis; 9. C. fallax; 10. P. taurica; 11. M. schencki. 
Bár a csalétkezések során a Temnothorax-fajokat csak génusz szintig azonosítottam, a legutolsó felvételezéseket követően begyüjtött mintaegyedek alapján mindkét élőhelyen legalább 3-3 fajuk (füredi tölgyes: T. affinis, T. crassispinus, T. parvulus; litéri fenyves: T. crassispinus, T. parvulus, T. unifasciatus) látogatta a csalétkeket.
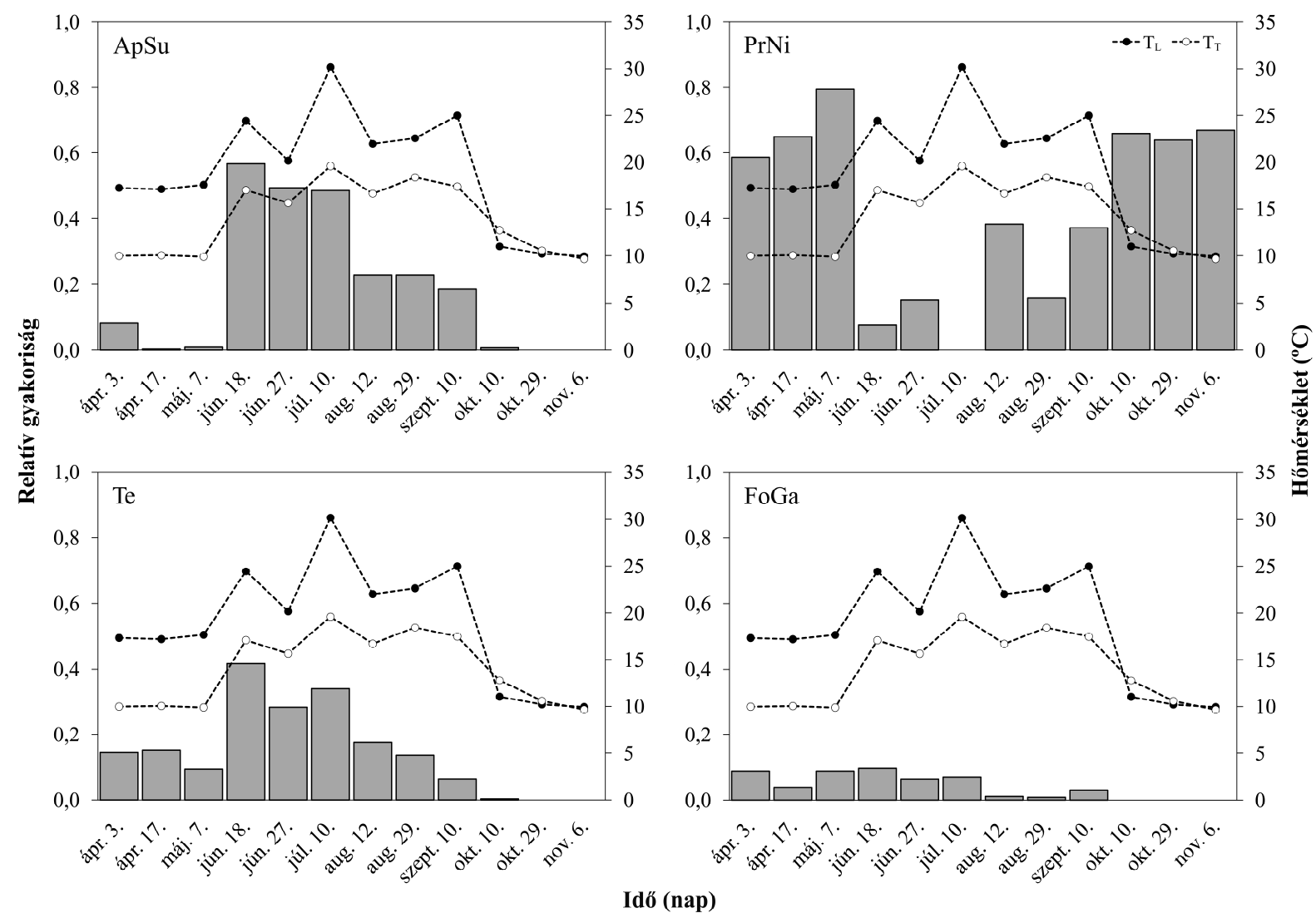

11. ábra. A gyakoribb fajok csalétkeken mutatott szezonális aktivitása a füredi tölgyesben. A relatív gyakoriságok a 12 (tavasz-nyár vége), ill. 10 órás (ősz) megfigyelések során elfoglalt csalétkek számának arányát jelentik a térben és időben maximálisan elfoglalható összcsalétekszámhoz (tavasz-nyár vége: $360=30$ csalétek $\times 12$ felvétel, ősz: $300=30$ csalétek $\times 10$ felvétel) viszonyítva. ApSu: Aphaenogaster subterranea; PrNi: Prenolepis nitens; Te: Temnothorax spp.; FoGa: Formica gagates; $\mathrm{T}_{\mathrm{L}}$ : átlag napi léghőmérséklet; $\mathrm{T}_{\mathrm{T}}$ : átlag napi talajhőmérséklet.

\section{Szezonális aktivitás}

A füredi tölgyesben a csalétkeket látogató gyakoribb fajok között egy olyan sem volt, amely az összes felvételezési napon detektálható lett volna a csalétkeken (11. ábra). Mind az A. subterranea, mind a Temnothorax-fajok aktivitása a nyár elején érte el maximumát, majd őszre fokozatosan visszaesett, ugyanakkor a tavaszi időszakban főként csak utóbbiak voltak aktívak. Ellentétben az előbbi fajokkal, a $P$. nitens esetében egy tavaszi-őszi kettős aktivitási csúcs volt megfigyelhető, míg a legkevésbé aktív periódusnak éppen a nyár eleji időszak 
bizonyult. A F. gagates elsősorban az évad első felében, tavasszal és nyár elején mutatott nagyobb aktivitást, bár összességében jóval kisebb mértéküt, mint azt a többi faj esetében regisztrálni lehetett.

A két leggyakoribb faj, az A. subterranea és a P. nitens, valamint a Temnothorax-fajok és a $P$. nitens szezonális aktivitásában a vártnál szignifikánsan kisebb, míg az A. subterranea és a Temnothorax-fajok szezonális aktivitásában a vártnál szignifikánsan nagyobb mértékü átfedés volt kimutatható (11. táblázat). A $F$. gagates és a többi gyakoribb faj közötti szezonális átfedés mértéke ugyanakkor egyik párosítás esetén sem különbözött szignifikánsan a véletlenszerütöl.

11. táblázat. A csalétkeken való aktivitás szezonális átfedésének mértéke a gyakoribb fajpárokra a füredi tölgyesben. Az egyes cellákban a megfigyelt, ill. zárójelben a véletlen eloszlás esetén várható Renkonen-index értékei szerepelnek. A vártnál szignifikánsabb kisebb értékek kismértékủ átfedést, míg az annál nagyobb értékek nagy átfedést jeleznek az illető fajok szezonális aktivitásában.

\begin{tabular}{lcccc}
\hline & ApSu & PrNi & FoGa & Te \\
Aphaenogaster subterranea & - & $\mathbf{0 , 2 8} * * *(\mathbf{0 , 5 7})$ & $0,61(0,64)$ & $\mathbf{0 , 8 2} *(\mathbf{0 , 6 7})$ \\
Prenolepis nitens & & - & $0,51(0,53)$ & $\mathbf{0 , 4 1}(\mathbf{0 , 5 7})$ \\
Formica gagates & & & - & $0,75(0,63)$ \\
Temnothorax spp. & & & & - \\
\hline
\end{tabular}

n.sz. $0,05<\mathrm{p} ; * 0,01<\mathrm{p}<0,05 ; * * 0,001<\mathrm{p}<0,01 ; * * * \mathrm{p}<0,001$

A litéri fenyvesben a csalétkeket látogató gyakoribb fajok közül egyedül az A. subterranea és a $F$. fusca voltak azok, amelyek minden egyes felvételezési napon regisztrálhatóak voltak a csalétkeken (12. ábra). Az A. subterranea szezonális aktivitási dinamikájának profilja szabályos haranggörbét követett az évad során, nyár elejéig fokozatosan növekvő, majd azt követően csökkenő relatív gyakorisági értékekkel. A $F$. fusca aktivitásának maximumát a nyár végi időszakban érte el, bár egy nagyobb aktivitási csúcs az utolsó tavaszi felvételezési napon is megfigyelhető volt. Más hangyafajokkal ellentétben a Temnothorax-fajok aktivitása tavasszal volt a legnagyobb, majd a tavaszi csúcsot követően nyárra jelentősen visszaesett, őszre pedig teljesen meg is szünt. A L. emarginatust nyár elejéig növekvő, majd azt követően erősen csökkenő aktivitás jellemezte, és a Temnothorax-fajokhoz hasonlóan az őszi periódusban már egyáltalán nem bizonyult aktívnak. A F. gagates az évad első felében, tavasszal és nyár elején mutatott viszonylag nagyobb, bár a többi fajhoz képest csekélyebb mértékü aktivitást, nyár végén és ősszel azonban már csak elvétve volt megfigyelhető a csalétkeken. 

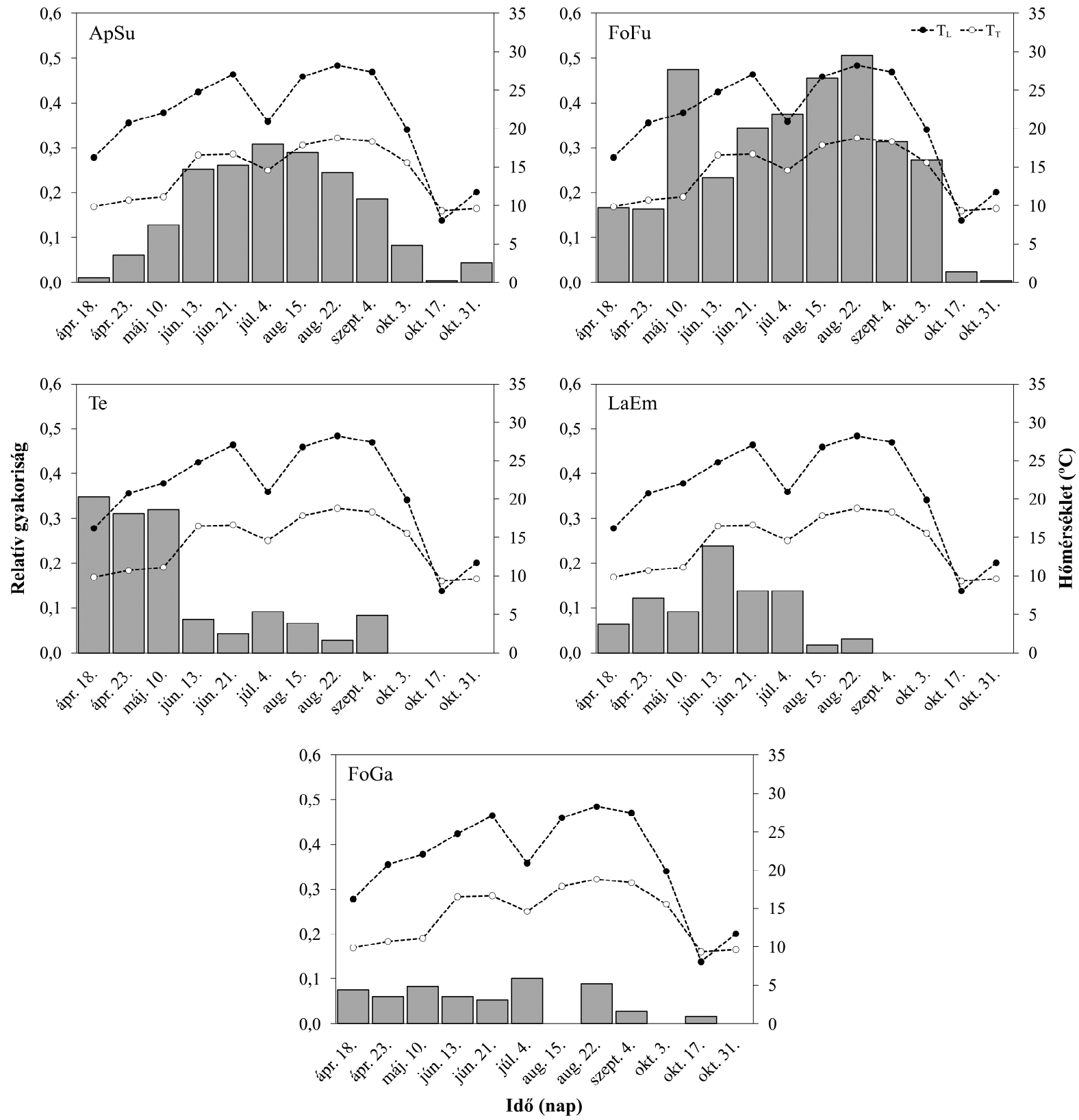

12. ábra. A gyakoribb fajok csalétkeken mutatott szezonális aktivitása a litéri fenyvesben. A relatív gyakoriságok a 12 (tavasz-nyár vége), ill. 10 órás (ősz) megfigyelések során elfoglalt csalétkek számának arányát jelentik a térben és időben maximálisan elfoglalható összcsalétekszámhoz (tavasz-nyár vége: $360=30$ csalétek $\times 12$ felvétel, ősz: $300=30$ csalétek $\times 10$ felvétel) viszonyítva. ApSu: Aphaenogaster subterranea; FoFu: Formica fusca; Te: Temnothorax spp.; LaEm: Lasius emarginatus; FoGa: Formica gagates; $\mathrm{T}_{\mathrm{L}}$ : átlag napi léghőmérséklet; $\mathrm{T}_{\mathrm{T}}$ : : átlag napi talajhőmérséklet.

A két leggyakoribb faj, az A. subterranea és a $F$. fusca, valamint a $F$. fusca és F. gagates szezonális aktivitásában a vártnál szignifikánsan nagyobb, míg az A. subterranea és a Temnothorax-fajok szezonális aktivitásában a vártnál szignifikánsan kisebb mértékü átfedés volt kimutatható (12. táblázat). Minden egyéb párosítás esetén a szezonális átfedés mértéke nem különbözött szignifikánsan a véletlenszerütől. 
12. táblázat. A csalétkeken való aktivitás szezonális átfedésének mértéke a gyakoribb fajpárokra a litéri fenyvesben. Az egyes cellákban a megfigyelt, ill. zárójelben a véletlen eloszlás esetén várható Renkonen-index értékei szerepelnek. A vártnál szignifikánsabb kisebb értékek kismértékủ átfedést, míg az annál nagyobb értékek nagy átfedést jeleznek az illető fajok szezonális aktivitásában.

\begin{tabular}{lccccc}
\hline & $\mathrm{ApSu}$ & $\mathrm{FoFu}$ & $\mathrm{Te}$ & $\mathrm{LaEm}$ & FoGa \\
& & $\mathbf{0 , 8 0 *}(\mathbf{0 , 6 7})$ & $\mathbf{0 , 3 9 *}(\mathbf{0 , 5 7})$ & $0,61(0,52)$ & $0,66(0,57)$ \\
Aphaenogaster subterranea & - & - & $0,53(0,57)$ & $0,56(0,53)$ & $\mathbf{0 , 7 3}(\mathbf{0 , 5 7})$ \\
Formica fusca & & & - & $0,52(0,63)$ & $0,61(0,60)$ \\
Temnothorax spp. & & & & - & $0,70(0,55)$ \\
Lasius emarginatus & & & & & - \\
Formica gagates & & & &
\end{tabular}

n.sz. $0,05<\mathrm{p} ; * 0,01<\mathrm{p}<0,05 ; * * 0,001<\mathrm{p}<0,01 ; * * * \mathrm{p}<0,001$

A füredi tölgyesben az A. subterranea és a Temnothorax-fajok szezonális aktivitása pozitívan, míg a $P$. nitensé negatívan korrelált mind a lég-, mind a talajhőmérséklettel (13. táblázat). A $F$. gagates esetében ezzel szemben nem volt kimutatható szignifikáns összefüggés a két változó között.

13. táblázat. A lineáris korrelációs koefficiens (r) értékei a csalétkeken mutatott szezonális aktivitás (elfoglalt csalétkek relatív aránya) és az átlag napi lég- $\left(\mathrm{T}_{\mathrm{L}}\right)$, ill. talajhőmérséklet $\left(\mathrm{T}_{\mathrm{T}}\right)$ között a gyakoribb fajok esetében a füredi tölgyesben. Mindegyik esetben n=12.

\begin{tabular}{lcc}
\hline & $\mathrm{r}\left(\mathrm{T}_{\mathrm{L}}\right)$ & $\mathrm{r}\left(\mathrm{T}_{\mathrm{T}}\right)$ \\
Aphaenogaster subterranea & $\mathbf{0 , 7 7} * *$ & $\mathbf{0 , 7 9} * *$ \\
Prenolepis nitens & $\mathbf{- 0 , 8 1 * *}$ & $\mathbf{- 0 , 9 1} * * *$ \\
Formica gagates & 0,49 & 0,07 \\
Temnothorax spp. & $\mathbf{0 , 7 5 * *}$ & $\mathbf{0 , 5 9} *$ \\
\hline n.sz. $0,05<\mathrm{p} ; * 0,01<\mathrm{p}<0,05 ; * * 0,001<\mathrm{p}<0,01 ; * * * \mathrm{p}<0,001$
\end{tabular}

A gyakoribb fajok mindegyike viszonylag széles, egymással jelentős mértékben átfedő hőmérsékleti intervallumon belül volt regisztrálható a csalétkeken (14. táblázat). Aktivitásának maximumát ugyanakkor a $P$. nitens a többi fajénál némiképp alacsonyabb hőmérsékleteken érte el, míg ellenben a Temnothorax-fajok a magasabb hömérsékleti tartományon belül voltak a legaktívabbak.

14. táblázat. A gyakoribb fajok csalétkeken mutatott aktivitásának hőmérsékleti tartományai a füredi tölgyesben. $\mathrm{T}_{\text {teljes: }}$ : a teljes aktivitás hőmérsékleti tartománya; $\mathrm{T}_{\text {max. }}$ : a maximális aktivitás (legtöbb elfoglalt csalétek) hőmérsékleti tartománya. Az egyes cellákban a léghőmérsékletre, ill. zárójelben a talajhőmérsékletre vonatkozó értékek szerepelnek.

\begin{tabular}{lcc}
\hline & $\mathrm{T}_{\text {teljes }}\left({ }^{\circ} \mathrm{C}\right)$ & $\mathrm{T}_{\max }\left({ }^{\circ} \mathrm{C}\right)$ \\
Aphaenogaster subterranea & $9,9-34,6(9,5-20,1)$ & $17,0-29,5(15,4-19,2)$ \\
Prenolepis nitens & $6,3-29,5(9,0-18,7)$ & $12,2-22,5(9,2-10,8)$ \\
Formica gagates & $9,8-34,6(9,1-20,1)$ & $18,4-33,6(9,5-20,1)$ \\
Temnothorax spp. & $9,9-34,6(9,2-20,1)$ & $25,5-33,0(17,1-20,1)$ \\
\hline
\end{tabular}


A litéri fenyvesben a két leggyakoribb faj, az A. subterranea és a $F$. fusca szezonális aktivitása pozitívan korrelált a lég- és talajhömérséklettel, míg a többi faj esetében az összefüggés nem volt szignifikáns (15. táblázat).

15. táblázat. A lineáris korrelációs koefficiens (r) értékei a csalétkeken mutatott szezonális aktivitás (elfoglalt csalétkek relatív aránya) és az átlag napi lég- $\left(\mathrm{T}_{\mathrm{L}}\right)$, ill. talajhőmérséklet $\left(\mathrm{T}_{\mathrm{T}}\right)$ között a gyakoribb fajok esetében a litéri fenyvesben. Mindegyik esetben $n=12$.

\begin{tabular}{lcc}
\hline & $\mathrm{r}\left(\mathrm{T}_{\mathrm{L}}\right)$ & $\mathrm{r}\left(\mathrm{T}_{\mathrm{T}}\right)$ \\
Aphaenogaster subterranea & $\mathbf{0 , 7 9} * *$ & $\mathbf{0 , 8 2} * *$ \\
Formica fusca & $\mathbf{0 , 8 3} * * *$ & $\mathbf{0 , 6 9}$ \\
Temnothorax spp. & 0,004 & $-0,45$ \\
Lasius emarginatus & 0,31 & 0,08 \\
Formica gagates & 0,29 & 0,01 \\
\hline n.sz. $0,05<\mathrm{p} ; * 0,01<\mathrm{p}<0,05 ; * * 0,001<\mathrm{p}<0,01 ; * * * \mathrm{p}<0,001$
\end{tabular}

Hasonlóan az előző élőhelyhez, a gyakoribb fajok itt is viszonylag széles, egymással nagyrészt átfedő hőmérséklet-tartományon belül látogatták a csalétkeket (16. táblázat). Valamelyest kisebb mértékü volt ugyanakkor az átfedés az A. subterranea, F. fusca és L. emarginatus, valamint a $F$. gagates és a Temnothorax-fajok maximális aktivitásának hőmérsékleti intervalluma között; míg előbbiek a magasabb hőmérsékleti tartományon belül bizonyultak a legaktívabbnak, addig utóbbiak aktivitásuk csúcsát már az ennél jóval alacsonyabb hömérsékleteken elérték.

16. táblázat. A gyakoribb fajok csalétkeken mutatott aktivitásának hőmérsékleti tartományai a litéri fenyvesben. $\mathrm{T}_{\text {teljes: }}$ a teljes aktivitás hőmérsékleti tartománya; $\mathrm{T}_{\text {max. }}$ : a maximális aktivitás (legtöbb elfoglalt csalétek) hőmérsékleti tartománya. Az egyes cellákban a léghőmérsékletre, ill. zárójelben a talajhőmérsékletre vonatkozó értékek szerepelnek.

\begin{tabular}{lcc}
\hline & $\mathrm{T}_{\text {teljes }}\left({ }^{\circ} \mathrm{C}\right)$ & $\mathrm{T}_{\max .}\left({ }^{\circ} \mathrm{C}\right)$ \\
Aphaenogaster subterranea & $9,7-32,5(9,4-19,8)$ & $20,1-29,1(14,7-19,8)$ \\
Formica fusca & $10,1-32,5(8,7-19,8)$ & $23,7-30,7(11,0-18,4)$ \\
Temnothorax spp. & $8,6-32,5(8,7-19,8)$ & $16,0-24,5(10,3-11,7)$ \\
Lasius emarginatus & $10,1-32,5(8,7-19,8)$ & $21,0-29,6(15,3-17,7)$ \\
Formica gagates & $10,3-32,5(8,7-19,8)$ & $14,4-27,5(8,7-18,2)$ \\
\hline
\end{tabular}

\section{Napi aktivitás}

A füredi tölgyesben a csalétkeket látogató két leggyakoribb faj, az A. subterranea és a P. nitens csalétkeken regisztrált napi aktivitási mintázata a szezonális aktivitásuk csúcsán egymástól lényegesen eltérő jelleget mutatott. 
Az A. subterranea napi aktivitását kezdetben növekvő, majd ezt követően a nyár elején erősebben vagy gyengébben csökkenő, míg a nyár végén inkább stagnáló tendencia jellemezte, amely nem csupán az elfoglalt csalétkek számában, hanem a csalétkeket látogató dolgozók egyedszámában is megmutatkozott (13. ábra).
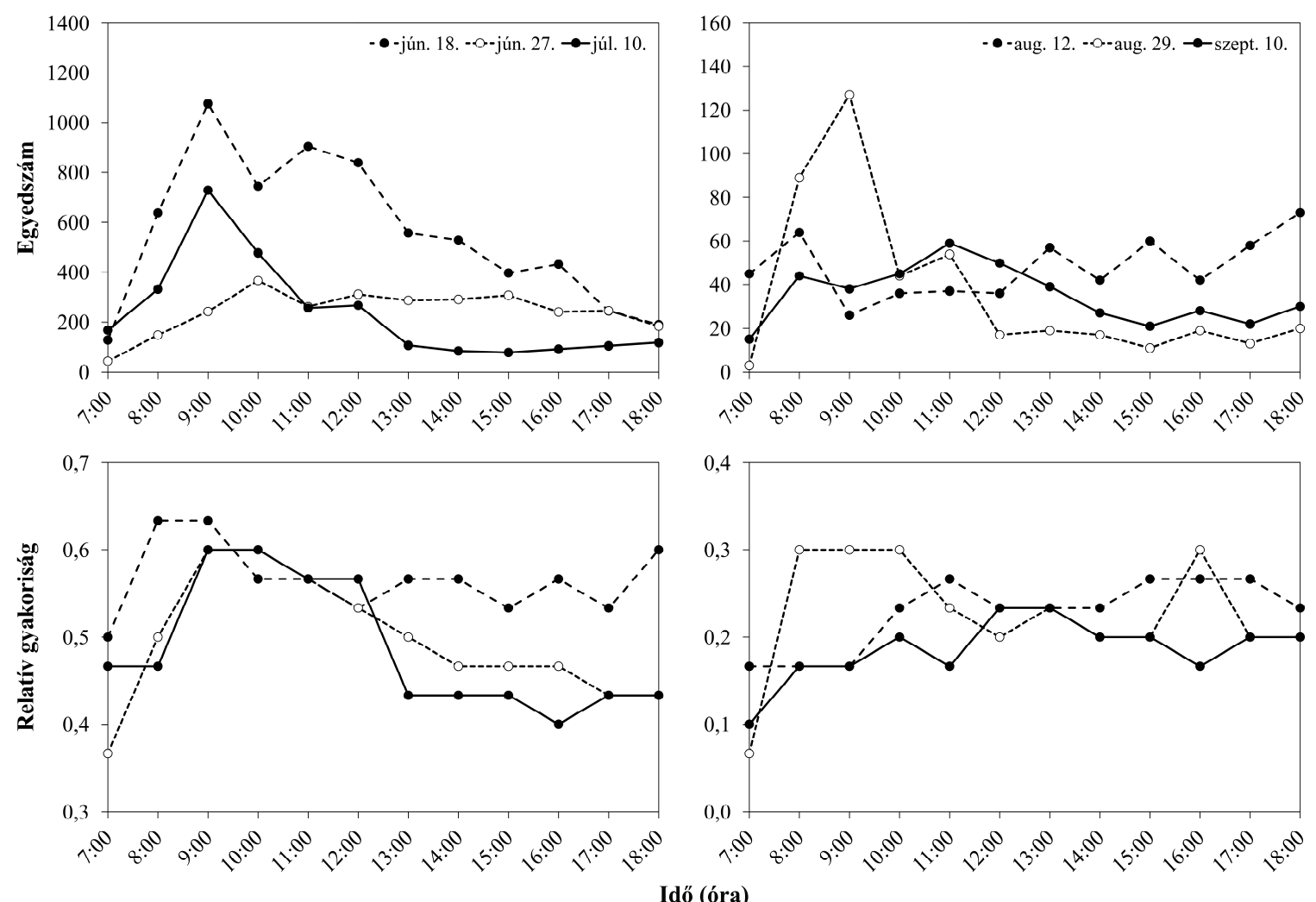

13. ábra. Az Aphaenogaster subterranea csalétkeken regisztrált egyedszámának és az elfoglalt csalétkek számának időbeli változása az egyes felvételezési napokon a faj szezonális aktivitása csúcsán a füredi tölgyesben. A relatív gyakoriságok a 12 órás megfigyelések során elfoglalt csalétkek számának arányát jelentik a térben és időben maximálisan elfoglalható összcsalétekszámhoz $(360=30$ csalétek $\times 12$ felvétel) viszonyítva.

A $P$. nitens esetében az elfoglalt csalétkek számának időbeli változása a tavaszi felvételezési napokon jellegzetes telítődési, míg ősszel a csalétkeket látogató dolgozók egyedszámáéhoz hasonlóan folyamatos növekedési tendenciát mutatott (14. ábra).

Az egyes gyakoribb fajok napi aktivitásban az esetek többségében a vártnál szignifikánsan nagyobb mértékü átfedés volt kimutatható (17. táblázat). Jelentős időbeli elkülönülés egyik fajpáros esetében sem volt megfigyelhető, a fentiektől eltérö minden egyéb esetben az átfedés mértéke nem különbözött szignifikánsan a véletlenszerütől. 

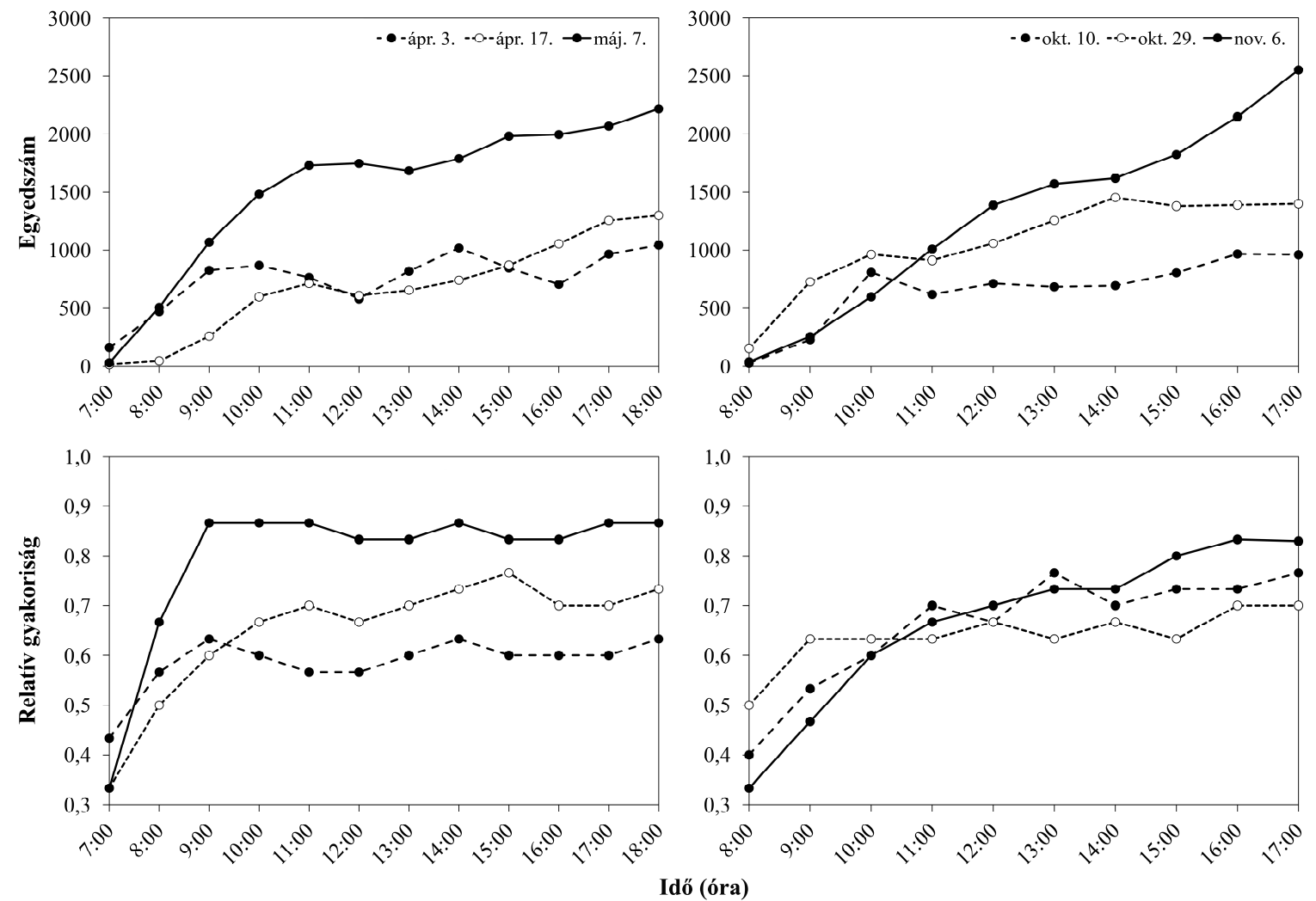

14. ábra. A Prenolepis nitens csalétkeken regisztrált egyedszámának és az elfoglalt csalétkek számának időbeli változása az egyes felvételezési napokon a faj szezonális aktivitása csúcsán a füredi tölgyesben. A relatív gyakoriságok a 12 (tavasz), ill. 10 órás (ősz) megfigyelések során elfoglalt csalétkek számának arányát jelentik a térben és időben maximálisan elfoglalható összcsalétekszámhoz (tavasz: $360=30$ csalétek $\times 12$ felvétel, ősz: $300=30$ csalétek $\times 10$ felvétel) viszonyítva.

17. táblázat. A csalétkeken való aktivitás (elfoglalt csalétkek száma) napi átfedésének mértéke a gyakoribb fajpárokra a füredi tölgyesben. $\mathrm{I}_{\mathrm{R}(\mathrm{M})}, \mathrm{I}_{\mathrm{R}(\mathrm{V})}$ : a megfigyelt, ill. a véletlen eloszlás esetén várható Renkonen-index értékei. A vártnál szignifikánsabb kisebb értékek kicsi, míg az annál nagyobb értékek nagy átfedést jeleznek az egyes fajpárok napi aktivitásában. ApSu: Aphaenogaster subterranea; PrNi: Prenolepis nitens; Te: Temnothorax spp.; FoGa: Formica gagates.

\begin{tabular}{lllllllllc}
\hline \multirow{5}{*}{ ApSu-PrNi } & & $\mathrm{I}_{\mathrm{R}(\mathrm{M})}$ & $\mathrm{I}_{\mathrm{R}(\mathrm{V})}$ & $\mathrm{p}$ & & & $\mathrm{I}_{\mathrm{R}(\mathrm{M})}$ & $\mathrm{I}_{\mathrm{R}(\mathrm{V})}$ & $\mathrm{p}$ \\
& aug. 12. & $\mathbf{0 , 9 3}$ & 0,67 & $<0,001$ & PrNi-Te & ápr. 3. & 0,72 & 0,64 & n.sz. \\
& aug. 29. & $\mathbf{0 , 8 9}$ & 0,67 & $<0,001$ & & ápr. 17. & 0,69 & 0,60 & n.sz. \\
& szept. 10. & $\mathbf{0 , 9 5}$ & 0,67 & $<0,001$ & & máj. 7. & $\mathbf{0 , 8 0}$ & 0,61 & $<0,01$ \\
ApSu-Te & & & & & & aug. 12. & $\mathbf{0 , 7 9}$ & 0,61 & $<0,01$ \\
& jún. 18. & $\mathbf{0 , 8 5}$ & 0,67 & $<0,01$ & & aug. 29. & $\mathbf{0 , 8 2}$ & 0,60 & $<0,01$ \\
& jún. 27. & $\mathbf{0 , 8 4}$ & 0,67 & $<0,01$ & & szept. 10. & 0,61 & 0,57 & n.sz. \\
& júl. 10. & $\mathbf{0 , 7 9}$ & 0,67 & $<0,05$ & & & & & \\
& aug. 12. & $\mathbf{0 , 7 6}$ & 0,61 & $<0,05$ & PrNi-FoGa & ápr. 3. & $\mathbf{0 , 8 4}$ & 0,67 & $<0,01$ \\
& aug. 29. & $\mathbf{0 , 7 6}$ & 0,61 & $<0,05$ & & ápr. 17. & 0,62 & 0,48 & n.sz. \\
ApSu-FoGa & jún. & & & & \\
& szept. 10. & 0,60 & 0,57 & n.sz. & & máj. 7. & $\mathbf{0 , 8 7}$ & 0,64 & $<0,001$ \\
& & & & & & & & & \\
& jún. 18. & $\mathbf{0 , 8 7}$ & 0,67 & $<0,001$ & FoGa-Te & ápr. 3. & $\mathbf{0 , 8 2}$ & 0,64 & $<0,01$ \\
& jún. 27. & 0,69 & 0,57 & n.sz. & & ápr. 17. & 0,67 & 0,54 & n.sz. \\
& júl. 10. & 0,65 & 0,61 & n.sz. & & máj. 7. & $\mathbf{0 , 8 1}$ & 0,64 & $<0,05$ \\
& & & & & & jún. 18. & $\mathbf{0 , 8 0}$ & 0,67 & $<0,05$ \\
& & & & & & jún. 27. & $\mathbf{0 , 7 7}$ & 0,57 & $<0,01$ \\
& & & & & & júl. 10. & $\mathbf{0 , 7 5}$ & 0,61 & $<0,05$ \\
\hline
\end{tabular}


A litéri fenyvesben, hasonlóan az előző élőhelyhez, a csalétkeket látogató két leggyakoribb faj, az A. subterranea és a $F$. fusca napi aktivitását a közös szezonális aktivitásuk csúcsán szintén egymástól eltérő mintázat jellemezte.

Az A. subterranea esetében az egyik hüvösebb nyári nap kivételével mind az elfoglalt csalétkek számának, mind a csalétkeket látogató dolgozók egyedszámának időbeli változása erősebb vagy gyengébb bimodális jelleget mutatott, reggeli és késő délutáni-esti maximális értékekkel (15. ábra).
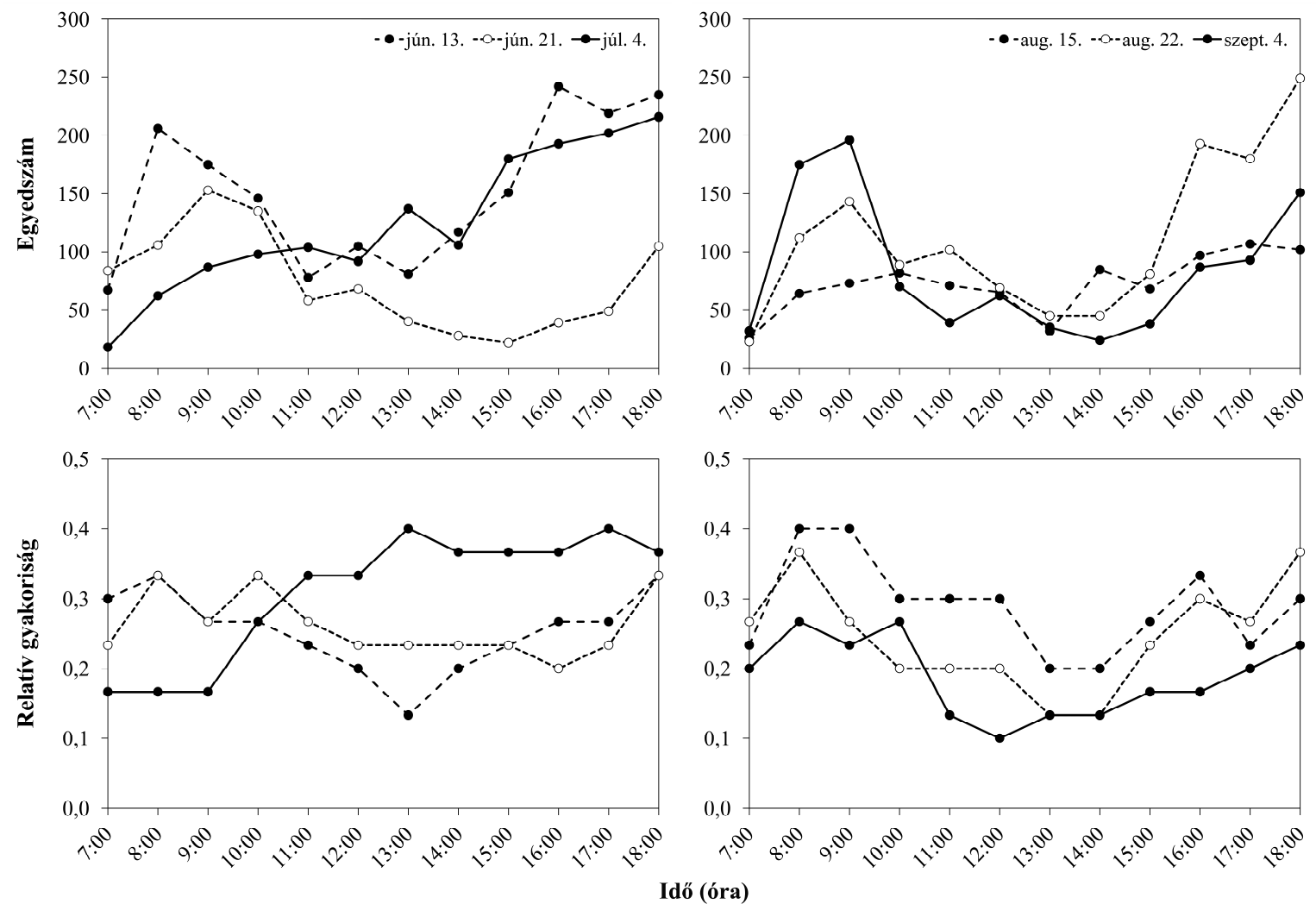

15. ábra. Az Aphaenogaster subterranea csalétkeken regisztrált egyedszámának és az elfoglalt csalétkek számának időbeli változása az egyes felvételezési napokon a faj szezonális aktivitása csúcsán a litéri fenyvesben. A relatív gyakoriságok a 12 órás megfigyelések során elfoglalt csalétkek számának arányát jelentik a térben és időben maximálisan elfoglalható összcsalétekszámhoz $(360=30$ csalétek $\times 12$ felvétel $)$ viszonyítva.

Az A. subterraneával ellentétben a $F$. fusca napi aktivitását a felvételezések első néhány órájában növekvő, majd ezt követően többnyire fokozatosan csökkenő vagy stagnáló tendencia jellemezte, amely szintén mind az általa látogatott csalétkek számában, mind a csalétkeken megjelenő dolgozók egyedszámában megmutatkozott (16. ábra).

A gyakoribb fajok csalétkeken mutatott napi aktivitása ezen az élöhelyen is többnyire a vártnál szignifikánsan nagyobb mértékü átfedést mutatott, míg a fennmaradó esetekben az átfedés mértéke nem különbözött szignifikánsan a véletlenszerütől (18. táblázat). 

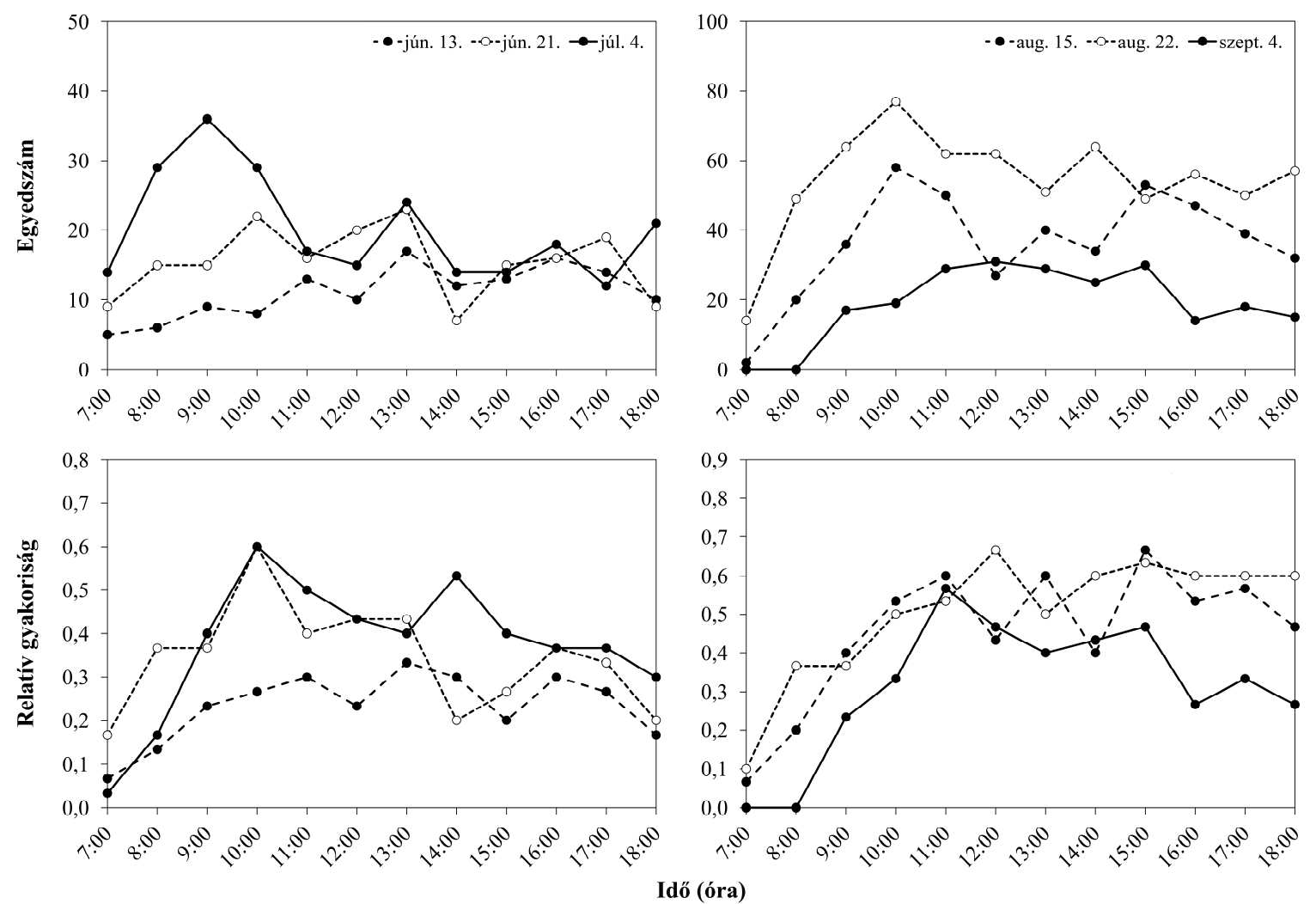

16. ábra. A Formica fusca csalétkeken regisztrált egyedszámának és az elfoglalt csalétkek számának időbeli változása az egyes felvételezési napokon a faj szezonális aktivitása csúcsán a litéri fenyvesben. A relatív gyakoriságok a 12 órás megfigyelések során elfoglalt csalétkek számának arányát jelentik a térben és időben maximálisan elfoglalható összcsalétekszámhoz $(360=30$ csalétek $\times 12$ felvétel $)$ viszonyítva.

18. táblázat. A csalétkeken való aktivitás (elfoglalt csalétkek száma) napi átfedésének mértéke a gyakoribb fajpárokra a litéri fenyvesben. $\mathrm{I}_{\mathrm{R}(\mathrm{M})}, \mathrm{I}_{\mathrm{R}(\mathrm{V})}$ : a megfigyelt, ill. a véletlen eloszlás esetén várható Renkonen-index értékei. A vártnál szignifikánsabb kisebb értékek kicsi, míg az annál nagyobb értékek nagy átfedést jeleznek az egyes fajpárok napi aktivitásában. ApSu: Aphaenogaster subterranea; FoFu: Formica fusca; Te: Temnothorax spp.; LaEm: Lasius emarginatus; FoGa: Formica gagates.

\begin{tabular}{lllllllllc}
\hline \multirow{4}{*}{ ApSu-FoFu } & & $\mathrm{I}_{\mathrm{R}(\mathrm{M})}$ & $\mathrm{I}_{\mathrm{R}(\mathrm{V})}$ & $\mathrm{p}$ & & & $\mathrm{I}_{\mathrm{R}(\mathrm{M})}$ & $\mathrm{I}_{\mathrm{R}(\mathrm{V})}$ & $\mathrm{p}$ \\
& jún. 13. & $\mathbf{0 , 8 0}$ & 0,67 & $<0,05$ & FoFu-LaEm & ápr. 18. & $\mathbf{0 , 8 4}$ & 0,67 & $<0,01$ \\
& jún. 21. & $\mathbf{0 , 8 5}$ & 0,67 & $<0,01$ & & ápr. 23. & $\mathbf{0 , 8 3}$ & 0,64 & $<0,01$ \\
& júl. 4. & $\mathbf{0 , 8 5}$ & 0,67 & $<0,01$ & & máj. 10. & $\mathbf{0 , 8 9}$ & 0,67 & $<0,001$ \\
& aug. 15. & $\mathbf{0 , 8 2}$ & 0,67 & $<0,05$ & & jún. 13. & $\mathbf{0 , 9 1}$ & 0,67 & $<0,001$ \\
& aug. 22. & $\mathbf{0 , 8 0}$ & 0,67 & $<0,05$ & & jún. 21. & $\mathbf{0 , 8 2}$ & 0,67 & $<0,05$ \\
& szept. 4. & 0,68 & 0,61 & n.sz. & & júl. 4. & $\mathbf{0 , 8 7}$ & 0,67 & $<0,001$ \\
ApSu-Te & & & & & & & & & \\
& jún. 13. & 0,75 & 0,64 & n.sz. & FoFu-FoGa & ápr. 18. & $\mathbf{0 , 8 0}$ & 0,64 & $<0,05$ \\
& jún. 21. & 0,73 & 0,61 & n.sz. & & ápr. 23. & 0,48 & 0,59 & n.sz. \\
& júl. 4. & $\mathbf{0 , 8 3}$ & 0,67 & $<0,05$ & & máj. 10. & 0,74 & 0,64 & n.sz. \\
& aug. 15. & 0,63 & 0,61 & n.sz. & & jún. 13. & $\mathbf{0 , 8 7}$ & 0,67 & $<0,001$ \\
& aug. 22. & 0,41 & 0,36 & n.sz. & jún. 21. & 0,71 & 0,61 & n.sz. \\
& szept. 4. & 0,67 & 0,64 & n.sz. & júl. 4. & $\mathbf{0 , 8 6}$ & 0,67 & $<0,01$ \\
\hline
\end{tabular}




\begin{tabular}{lllllllllc}
\hline \multirow{4}{*}{ ApSu-LaEm } & & $\mathrm{I}_{\mathrm{R}(\mathrm{M})}$ & $\mathrm{I}_{\mathrm{R}(\mathrm{V})}$ & $\mathrm{p}$ & & & $\mathrm{I}_{\mathrm{R}(\mathrm{M})}$ & $\mathrm{I}_{\mathrm{R}(\mathrm{V})}$ & $\mathrm{p}$ \\
& jún. 13. & $\mathbf{0 , 8 3}$ & 0,67 & $<0,01$ & Te-LaEm & ápr. 18. & $\mathbf{0 , 8 4}$ & 0,64 & $<0,01$ \\
& jún. 21. & $\mathbf{0 , 8 9}$ & 0,67 & $<0,001$ & & ápr. 23. & $\mathbf{0 , 8 8}$ & 0,67 & $<0,01$ \\
& júl. 4. & $\mathbf{0 , 8 7}$ & 0,67 & $<0,01$ & & máj. 10. & $\mathbf{0 , 8 9}$ & 0,64 & $<0,001$ \\
ApSu-FoGa & & & & & & jún. 13. & 0,75 & 0,64 & n.sz. \\
& jún. 13. & $\mathbf{0 , 8 9}$ & 0,67 & $<0,001$ & & jún. 21. & 0,71 & 0,61 & n.sz. \\
& jún. 21. & 0,73 & 0,61 & n.sz. & & júl. 4. & $\mathbf{0 , 8 2}$ & 0,67 & $<0,05$ \\
& júl. 4. & $\mathbf{0 , 8 9}$ & 0,67 & $<0,001$ & & & & & \\
FoFu-Te & & & & & Te-FoGa & ápr. 18. & $\mathbf{0 , 8 8}$ & 0,61 & $<0,001$ \\
& ápr. 18. & $\mathbf{0 , 8 4}$ & 0,64 & $<0,01$ & & ápr. 23. & 0,55 & 0,56 & n.sz. \\
& ápr. 23. & $\mathbf{0 , 8 5}$ & 0,64 & $<0,01$ & & máj. 10. & $\mathbf{0 , 8 1}$ & 0,67 & $<0,05$ \\
& máj. 10. & $\mathbf{0 , 8 7}$ & 0,64 & $<0,001$ & & jún. 13. & $\mathbf{0 , 7 8}$ & 0,64 & $<0,05$ \\
& jún. 13. & 0,74 & 0,64 & n.sz. & & jún. 21. & $\mathbf{0 , 6 9}$ & 0,54 & $<0,05$ \\
& jún. 21. & 0,64 & 0,61 & n.sz. & & júl. 4. & $\mathbf{0 , 8 3}$ & 0,67 & $<0,01$ \\
& júl. 4. & $\mathbf{0 , 8 2}$ & 0,67 & $<0,05$ & & & & & \\
& aug. 15. & 0,69 & 0,61 & n.sz. & LaEm-FoGa & ápr. 18. & $\mathbf{0 , 8 3}$ & 0,64 & $<0,01$ \\
& aug. 22. & 0,48 & 0,37 & n.sz. & & ápr. 23. & 0,52 & 0,56 & n.sz. \\
& szept. 4. & 0,74 & 0,64 & n.sz. & & máj. 10. & 0,74 & 0,64 & n.sz. \\
& & & & & & jún. 13. & $\mathbf{0 , 9 1}$ & 0,67 & $<0,001$ \\
& & & & & jún. 21. & 0,72 & 0,61 & n.sz. \\
& & & & & júl. 4. & $\mathbf{0 , 9 0}$ & 0,67 & $<0,001$ \\
\hline
\end{tabular}

Térbeli elkülönülés $I$.

A füredi tölgyesben a felvételezések során regisztrált összes hangyafaj között szignifikáns különbség volt kimutatható a tekintetben, hogy a talajon vagy a fákon elhelyezett csalétkeket látogatták-e inkább (Khi-négyzet próba, $\chi^{2}=526,09 ; \mathrm{df}=9 ; \mathrm{p}<0,001$ ). Míg az arboreális életmódú fajok, valamint a L. brunneus és L. emarginatus nagyrészt vagy kizárólag a fákon lévő csalétkeken fordultak elő, addig a gyakoribb fajok, azaz az A. subterranea, $P$. nitens, F. gagates és a Temnothorax-fajok a talajon elhelyezett csalétkeken jelentek meg nagyobb arányban, bár utóbbiak e tekintetben ugyancsak szignifikánsan különböztek egymástól ( $\left.\chi^{2}=141,34 ; \mathrm{df}=3 ; \mathrm{p}<0,001\right)$ (17. ábra).

A litéri fenyvesben az előző élőhelyhez hasonlóan mind a csalétkeken regisztrált összes faj, mind külön a gyakoribb fajok szignifikáns különbséget mutattak a talajon és fákon elhelyezett csalétkek látogatottságának tekintetében (Khi-négyzet próba, összes faj: $\chi^{2}=758,07 ; \mathrm{df}=10 ; \mathrm{p}<0,001 ;$ gyakoribb fajok: $\left.\chi^{2}=623,79 ; \mathrm{df}=4 ; \mathrm{p}<0,001\right)$ (18. ábra). Utóbbiak közül a L. emarginatus, ill. a két Serviformica-faj fordult elő viszonylag nagyobb arányban a fákon lévő csalétkeken, míg velük szemben az A. subterranea és a Temnothorax-fajok majdnem kizárólag csak a talajon elhelyezett csalétkeket látogatták. 


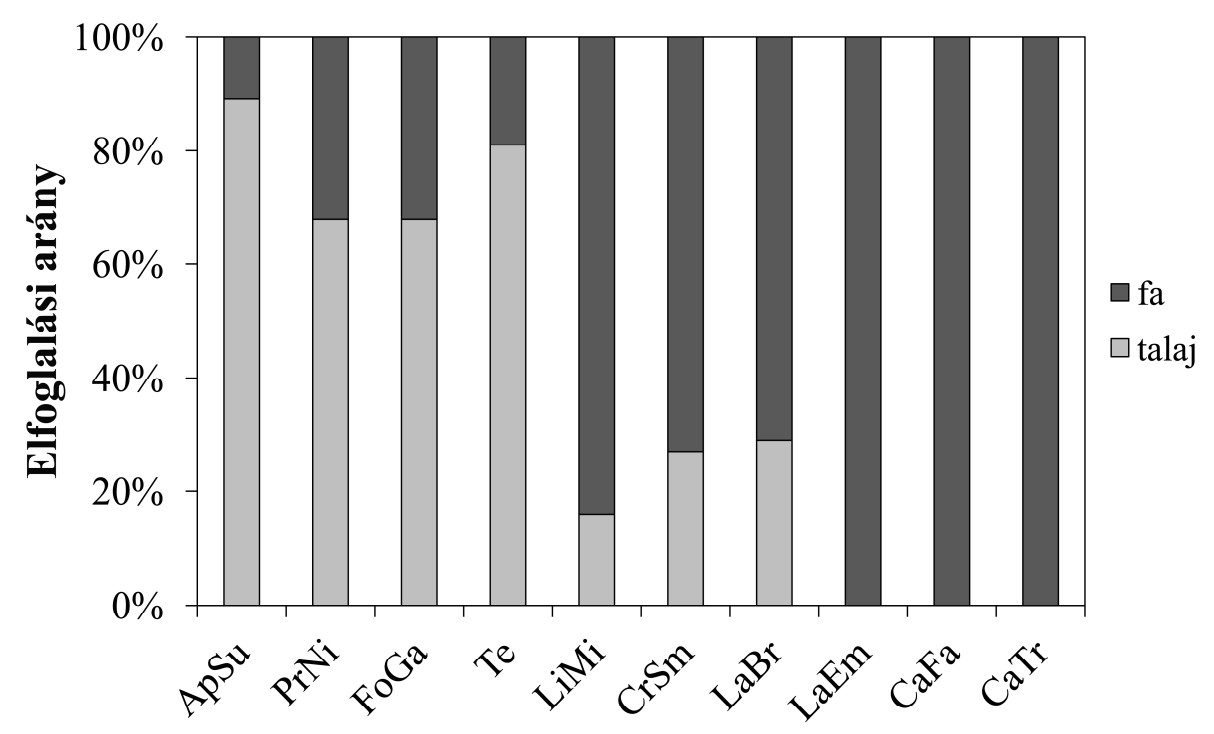

Fajok

17. ábra. A talajon és fákon elhelyezett csalétkek látogatottságának százalékos aránya a felvételezések során regisztrált összes hangyafajnál a füredi tölgyesben. ApSu: Aphaenogaster subterranea; PrNi: Prenolepis nitens; FoGa: Formica gagates; Te: Temnothorax spp.; LiMi: Liometopum microcephalum; CrSm: Crematogaster schmidti; LaBr: Lasius brunneus; LaEm: Lasius emarginatus; CaFa: Camponotus fallax; CaTr: Camponotus truncatus.

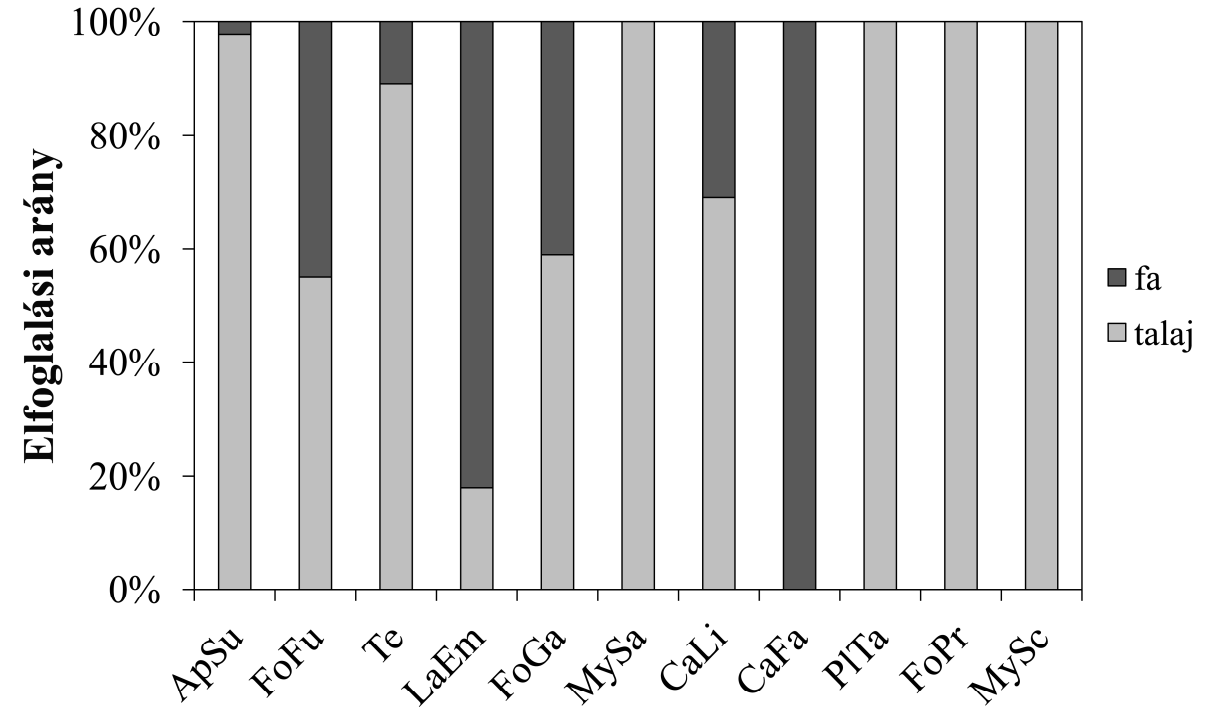

Fajok

18. ábra. A talajon és fákon elhelyezett csalétkek látogatottságának százalékos aránya a felvételezések során regisztrált összes hangyafajnál a litéri fenyvesben. ApSu: Aphaenogaster subterranea; FoFu: Formica fusca; Te: Temnothorax spp.; LaEm: Lasius emarginatus; FoGa: Formica gagates; MySa: Myrmica sabuleti; CaLi: Camponotus ligniperdus; CaFa: Camponotus fallax; PITa: Plagiolepis taurica; FoPr: Formica pratensis; MySc: Myrmica schencki. 
A füredi tölgyesben a csalétkek felfedezési hatékonysága összességében a $P$. nitens esetében volt a legnagyobb, amely mind a látogatott, mind a tartósan elfoglalt csalétkek több mint 80\%-ára érkezett elsőként (19. táblázat, Függelék 7. táblázat). E tekintetben a legkevésbé sikeresek a Temnothorax-fajok voltak, amelyek bár viszonylag sok csalétken jelentek meg, ill. tartózkodtak huzamosabban, ugyanakkor ezeknek csupán közel 10\%-át fedezték fel elsőként.

19. táblázat. A gyakoribb fajok csalétek felfedezési hatékonysága a füredi tölgyesben.

\begin{tabular}{lcccc}
\hline Fajok & $\begin{array}{c}\text { látogatott } \\
\text { csalétkek }^{1}\end{array}$ & $\begin{array}{c}\text { elsöként } \\
\text { jelen }^{2}\end{array}$ & $\begin{array}{c}\text { elfoglalt } \\
\text { csalétkek }^{3}\end{array}$ & $\begin{array}{c}\text { elsőként } \\
\text { jelen }^{4}\end{array}$ \\
Prenolepis nitens & 0,62 & 0,84 & 0,51 & 0,87 \\
Aphaenogaster subterranea & 0,37 & 0,55 & 0,27 & 0,60 \\
Formica gagates & 0,20 & 0,15 & 0,06 & 0,19 \\
Temnothorax spp. & 0,47 & 0,11 & 0,29 & 0,08 \\
\hline
\end{tabular}

${ }^{1}$ A látogatott csalétkek (amelyeken az illető faj megjelent) és az összes csalétek (max. 30/nap) hányada.

${ }^{2}$ A látogatott csalétkek azon hányada, ahol az illető faj elsőként jelent meg.

${ }^{3} \mathrm{~A}$ tartósan elfoglalt csalétkek (amelyeken az illető faj legalább az észlelések harmadában megfigyelhető volt) és az összes csalétek hányada.

${ }^{4}$ A tartósan elfoglalt csalétkek azon hányada, ahol az illető faj elsőként jelent meg.

Az egyes gyakoribb fajok csalétek felfedezési idejében szignifikáns különbség volt kimutatható (Kruskal-Wallis próba, $\chi^{2}=118,10$; df=3; p<0,001); az A. subterranea és a $P$. nitens a látogatott csalétkeket összességében a $F$. gagatesnél és a Temnothorax-fajoknál jelentősen rövidebb idő alatt fedezte fel, ugyanakkor sem elöbbiek, sem utóbbiak nem különböztek e tekintetben egymástól szignifikánsan (20. táblázat, Függelék 7. táblázat).

20. táblázat. A gyakoribb fajok csalétek felfedezési (tkp. az adott csalétken való első, órában kifejezett észlelési) idejének átlaga a szórással a füredi tölgyesben. A Mann-Whitney U-teszt alapján egymástól szignifikánsan különböző $(p<0,05)$ fajokat különbözö betüjelek jelölik.

\begin{tabular}{lcc}
\hline Fajok & $\begin{array}{c}\text { felfedezési idő } \\
\text { (óra) }\end{array}$ & $\mathrm{n}$ \\
& $2,55 \pm 2,31^{\mathrm{a}}$ & 110 \\
Aphaenogaster subterranea & $2,56 \pm 2,09^{\mathrm{a}}$ & 206 \\
Prenolepis nitens & $4,84 \pm 2,74^{\mathrm{b}}$ & 142 \\
Temnothorax spp. & $5,67 \pm 2,62^{\mathrm{b}}$ & 55 \\
\hline
\end{tabular}

A két leggyakoribb faj, az A. subterranea és a $P$. nitens csalétek-fészek távolságai között nem volt kimutatható szignifikáns különbség, mindkét faj esetében a csalétkeket többnyire az 1 m-en belül fészkelő kolóniák tagjai látogatták (Mann-Whitney U-teszt, $\left.\mathrm{z}=-0,80 ; \mathrm{p}=0,43 ; \mathrm{n}_{\mathrm{ApSu}}=43 ; \mathrm{n}_{\mathrm{PrNi}}=56\right)$ (19. ábra). A $P$. nitens esetében a csalétkek felfedezési 
ideje gyengén korrelált azoknak a fészektől való távolságával (azaz minél közelebb helyezkedtek el a csalétkek a fészkeikhez, annál rövidebb idő alatt fedezték fel azokat), míg ezzel szemben az A. subterranea esetében a két változó nem mutatott szignifikáns összefüggést (Spearman-féle korrelációs teszt, PrNi: r=0,27; p<0,05; n=56; ApSu: r=0,005; $\mathrm{p}=0,98 ; \mathrm{n}=43)$.

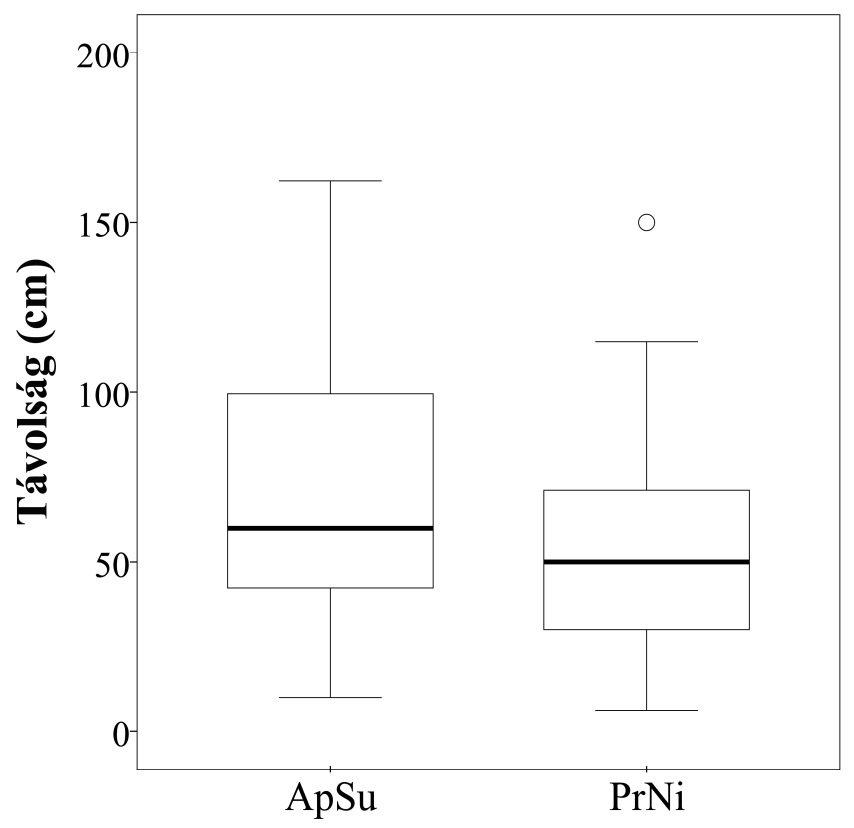

Fajok

19. ábra. A csalétek-fészek távolságok a füredi tölgyes két leggyakoribb fajánál. A boxok az interkvartilis tartományt, a boxokban lévő vízszintes vonalak a mediánokat, a talpak az interkvartilis tartomány 1,5-szereseit, az üres körök pedig a kiugró értékeket jelölik. ApSu: Aphaenogaster subterranea; PrNi: Prenolepis nitens.

A litéri fenyvesben a gyakoribb fajok csalétek felfedezési hatékonysága viszonylag nagymértékben különbözött egymástól, bár az ez alapján felállított rangsorban közvetlenül egymást követő fajok közötti eltérések az előző élőhelyhez képest jelentősen kisebbek voltak (21. táblázat, Függelék 8. táblázat). A legnagyobb felfedezési hatékonyság az A. subterraneát jellemezte, amely mind a látogatott, mind a tartósan elfoglalt csalétkek közel 60\%-ára érkezett elsőként, míg a legkevésbé sikeresnek a füredi tölgyeshez hasonlóan a Temnothorax-fajok bizonyultak.

A csalétkek felfedezési ideje tekintetében szignifikáns különbség mutatkozott az egyes gyakoribb fajok között (Kruskal-Wallis próba, $\chi^{2}=63,35 ; \mathrm{df}=4 ; \mathrm{p}<0,001$ ); az A. subterranea mellett viszonylag rövidebb felfedezési idő jellemezte a $F$. gagatest és a $L$. emarginatust, míg a $F$. fusca és a Temnothorax-fajok a látogatott csalétkeket az előbbiekhez képest jelentősen hosszabb idő alatt fedezték fel (22. táblázat, Függelék 8. táblázat). 
21. táblázat. A gyakoribb fajok csalétek felfedezési hatékonysága a litéri fenyvesben.

\begin{tabular}{lcccc}
\hline Fajok & $\begin{array}{c}\text { látogatott } \\
\text { csalétkek }^{1}\end{array}$ & $\begin{array}{c}\text { elsőként } \\
\text { jelen }^{2}\end{array}$ & $\begin{array}{c}\text { elfoglalt } \\
\text { csalétkek }^{3}\end{array}$ & $\begin{array}{c}\text { elsőként } \\
\text { jelen }^{4}\end{array}$ \\
Aphaenogaster subterranea & 0,30 & 0,57 & 0,20 & 0,62 \\
Formica fusca & 0,65 & 0,45 & 0,43 & 0,52 \\
Lasius emarginatus & 0,19 & 0,44 & 0,13 & 0,56 \\
Formica gagates & 0,13 & 0,39 & 0,08 & 0,41 \\
Temnothorax spp. & 0,42 & 0,20 & 0,20 & 0,31 \\
\hline
\end{tabular}

${ }^{1}$ A látogatott csalétkek (amelyeken az illető faj megjelent) és az összes csalétek (max. 30/nap) hányada.

${ }^{2}$ A látogatott csalétkek azon hányada, ahol az illető faj elsőként jelent meg.

${ }^{3} \mathrm{~A}$ tartósan elfoglalt csalétkek (amelyeken az illető faj legalább az észlelések harmadában megfigyelhető volt) és az összes csalétek hányada.

${ }^{4}$ A tartósan elfoglalt csalétkek azon hányada, ahol az illetổ faj elsőként jelent meg.

22. táblázat. A gyakoribb fajok csalétek felfedezési (tkp. az adott csalétken való első, órában kifejezett észlelési) idejének átlaga a szórással a litéri fenyvesben. A Mann-Whitney U-teszt alapján egymástól szignifikánsan különböző $(p<0,05)$ fajokat különböző betüjelek jelölik.

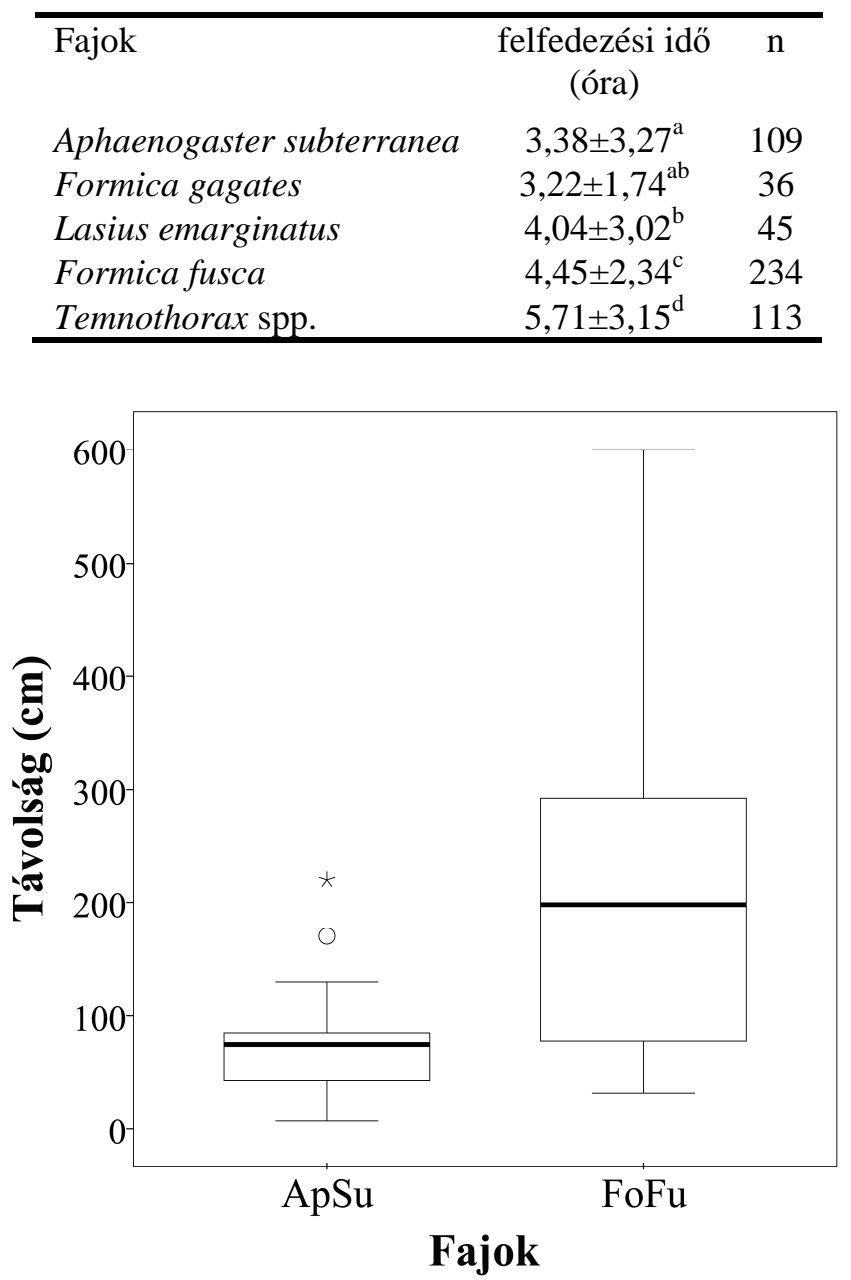

20. ábra. A csalétek-fészek távolságok a litéri fenyves két leggyakoribb fajánál. A boxok az interkvartilis tartományt, a boxokban lévő vízszintes vonalak a mediánokat, a talpak az interkvartilis tartomány 1,5-szereseit, az üres körök és csillagok pedig a kiugró-, ill. az extrém kiugró értékeket jelölik. ApSu: Aphaenogaster subterranea; FoFu: Formica fusca. 
A két leggyakoribb faj, az A. subterranea és a $F$. fusca csalétek-fészek távolságai között szignifikáns különbség volt kimutatható, utóbbi faj dolgozói a látogatott csalétkekre rendszerint az előző faj dolgozóinál jóval nagyobb távolságból érkeztek (Mann-Whitney U-teszt, z=-3,66; $\mathrm{p}<0,001 ; \mathrm{n}_{\mathrm{ApSu}}=31 ; \mathrm{n}_{\mathrm{FoFu}}=23$ ) (20. ábra). A csalétkek felfedezési ideje és fészektől való távolsága a két faj egyikének esetében sem mutatott szignifikáns összefüggést (Spearman-féle korrelációs teszt, ApSu: r=-0,20; p=0,28; n=31; FoFu: r=0,26; p=0,24; n=23).

Táplálékpreferencia, táplálkozási hatékonyság

A füredi tölgyes gyakoribb fajai közül a $P$. nitens táplálékpreferenciája jellegzetes szezonális változást mutatott; aktivitása csúcsán, a tavaszi és őszi periódusban a csalétkeket látogató dolgozói a mézet, a nyár eleji inaktívabb időszakban pedig a tonhalat részesítették inkább előnyben, míg a nyári végén többnyire nem volt kimutatható szignifikáns különbség a kétféle csali preferenciájában (23. táblázat). Eltérően a $P$. nitenstől, az A. subterranea kolóniáinak tagjai a tonhalra a felvételezési napok mindegyikén rendre szignifikánsan több egyedet rekrutáltak, míg ellenben a $F$. gagates és a Temnothorax-fajok többnyire nem mutattak határozott táplálékpreferenciát az évad során.

Az egyes gyakoribb fajok táplálkozási hatékonysága az A. subterranea kivételével, amelynél a táplálkozó egyedek aránya az összes jelenlévő egyedhez képest közel azonos volt a kétféle csali esetében, szignifikánsan nagyobb volt a mézen (24. táblázat).

Táplálkozási hatékonyságuk tekintetében az egyes fajok között mind a méz-méz, mind a tonhal-tonhal összehasonlításban szignifikáns különbség volt kimutatható (Kruskal-Wallis próba, méz: $\chi^{2}=550,64 ; \mathrm{df}=3 ; \mathrm{p}<0,001$; tonhal: $\chi^{2}=211,97 ; \mathrm{df}=3 ; \mathrm{p}<0,001$ ); viszonylag nagy táplálkozási hatékonyság jellemezte a $P$. nitenst és a $F$. gagatest, míg az A. subterranea és a Temnothorax-fajok esetében a táplálkozó egyedek relatív aránya ezekhez képest jóval alacsonyabb volt (24. táblázat, Függelék 9. táblázat).

24. táblázat. A gyakoribb fajok táplálkozási hatékonysága (a táplálkozó egyedek és az összes egyed hányadosának átlaga a szórással) a kétféle táplálékforráson a füredi tölgyesben. A Mann-Whitney U-teszt alapján egymástól szignifikánsan különböző $(p<0,05)$ fajokat különböző betüjelek jelölik.

\begin{tabular}{|c|c|c|c|c|c|}
\hline & méz & $\mathrm{n}$ & tonhal & $\mathrm{n}$ & Mann-Whitney z \\
\hline Prenolepis nitens & $0,82 \pm 0,17^{\mathrm{a}}$ & 1670 & $0,62 \pm 0,25^{\mathrm{a}}$ & 1488 & $-28,47 * * *$ \\
\hline Formica gagates & $\mathbf{0 , 7 5} \pm 0,38^{\mathrm{b}}$ & 109 & $0,60 \pm 0,41^{\mathrm{a}}$ & 134 & $-3,17 * *$ \\
\hline Aphaenogaster subterranea & $0,52 \pm 0,30^{\mathrm{c}}$ & 667 & $0,55 \pm 0,30^{\mathrm{b}}$ & 727 & $-1,70$ n.sz. \\
\hline Temnothorax spp. & $0,52 \pm 0,43^{c}$ & 482 & $0,31 \pm 0,40^{\mathrm{c}}$ & 396 & $-7,19 * * *$ \\
\hline
\end{tabular}

n.sz. $0,05<\mathrm{p} ; * 0,01<\mathrm{p}<0,05 ; * * 0,001<\mathrm{p}<0,01 ; * * * \mathrm{p}<0,001$ 
23. táblázat. A gyakoribb fajok csalétkeken mutatott szezonális táplálékpreferenciája (átlagegyedszám a szórással a kétféle táplálékforráson) a füredi tölgyesben.

\begin{tabular}{|c|c|c|c|c|c|c|c|c|}
\hline & \multicolumn{4}{|c|}{ A. subterranea } & \multicolumn{4}{|l|}{ P. nitens } \\
\hline & méz & tonhal & Wilcoxon $\mathrm{z}$ & $\mathrm{n}$ & méz & tonhal & Wilcoxon z & $\mathrm{n}$ \\
\hline ápr. 3. & $0,97 \pm 3,35$ & $4,86 \pm 4,41$ & $4,21 * * *$ & 29 & $31,34 \pm 21,63$ & $11,67 \pm 11,11$ & $11,48 * * *$ & 211 \\
\hline ápr. 17. & - & - & - & 1 & $26,02 \pm 18,99$ & $8,66 \pm 10,18$ & $13,04 * * *$ & 234 \\
\hline máj. 7. & - & - & - & 3 & $34,68 \pm 23,08$ & $29,31 \pm 20,47$ & $4,04 * * *$ & 286 \\
\hline jún. 18. & $12,09 \pm 10,05$ & $20,7 \pm 19,28$ & $8,03^{* * *}$ & 204 & $4,96 \pm 6,35$ & $15,07 \pm 21,30$ & $2,48^{*}$ & 27 \\
\hline jún. 27. & $7,36 \pm 6,96$ & $9,08 \pm 10,12$ & $2,75 * *$ & 178 & $8,24 \pm 8,53$ & $18,71 \pm 17,24$ & $4,01 * * *$ & 55 \\
\hline júl. 10. & $6,41 \pm 8,11$ & $9,60 \pm 10,97$ & $6,14^{* * *}$ & 175 & - & - & - & 0 \\
\hline aug. 12 . & $3,27 \pm 5,05$ & $3,76 \pm 3,69$ & $1,98^{*}$ & 82 & $16,11 \pm 12,79$ & $15,41 \pm 17,37$ & 1,04 n.sz. & 138 \\
\hline aug. 29. & $2,04 \pm 3,60$ & $3,16 \pm 5,90$ & $3,00 * *$ & 82 & $25,63 \pm 19,01$ & $21,44 \pm 19,35$ & $2,09 *$ & 57 \\
\hline szept. 10. & $1,82 \pm 2,82$ & $4,42 \pm 4,26$ & $4,20 * * *$ & 67 & $22,99 \pm 12,92$ & $20,49 \pm 14,64$ & 1,90 n.sz. & 134 \\
\hline okt. 10 . & - & - & - & 2 & $17,85 \pm 15,51$ & $14,99 \pm 13,14$ & $2,94 * *$ & 198 \\
\hline okt. 29. & - & - & - & 0 & $35,02 \pm 22,42$ & $20,60 \pm 13,36$ & $9,27 * * *$ & 192 \\
\hline \multirow[t]{3}{*}{ nov. 6.} & - & - & - & 0 & $43,03 \pm 28,99$ & $19,66 \pm 14,08$ & $11,44 * * *$ & 201 \\
\hline & \multicolumn{4}{|c|}{ Temnothorax spp. } & \multicolumn{4}{|l|}{ F. gagates } \\
\hline & méz & tonhal & Wilcoxon $\mathrm{z}$ & $\mathrm{n}$ & méz & tonhal & Wilcoxon $\mathrm{z}$ & $\mathrm{n}$ \\
\hline ápr. 3 . & $1,19 \pm 1,36$ & $0,88 \pm 1,02$ & 1,11 n.sz. & 52 & $5,94 \pm 7,23$ & $3,44 \pm 4,51$ & 1,48 n.sz. & 32 \\
\hline ápr. 17. & $0,78 \pm 1,29$ & $1,40 \pm 1,61$ & $2,12 *$ & 55 & $1,43 \pm 1,95$ & $0,14 \pm 0,36$ & $2,68 * *$ & 14 \\
\hline máj. 7. & $1,62 \pm 2,30$ & $0,97 \pm 1,38$ & 1,78 n.sz. & 34 & $3,75 \pm 5,21$ & $2,31 \pm 2,90$ & 1,25 n.sz. & 32 \\
\hline jún. 18. & $2,77 \pm 3,14$ & $1,27 \pm 1,68$ & $6,08 * * *$ & 150 & $4,46 \pm 5,43$ & $4,80 \pm 5,94$ & 0,98 n.sz. & 35 \\
\hline jún. 27. & $1,66 \pm 2,02$ & $1,25 \pm 1,61$ & 1,92 n.sz. & 102 & $0,43 \pm 0,51$ & $0,78 \pm 0,67$ & $1,52 \mathrm{n} . \mathrm{sz}$. & 23 \\
\hline júl. 10. & $2,23 \pm 1,66$ & $0,67 \pm 1,16$ & $7,40 * * *$ & 122 & $0,31 \pm 0,55$ & $2,12 \pm 2,29$ & $3,94 * * *$ & 26 \\
\hline aug. 12 . & $1,32 \pm 1,33$ & $1,62 \pm 1,43$ & 1,05 n.sz. & 63 & - & - & - & 4 \\
\hline aug. 29 . & $1,04 \pm 1,26$ & $1,18 \pm 0,88$ & 1,13 n.sz. & 49 & - & - & - & 3 \\
\hline szept. 10. & $0,57 \pm 0,79$ & $1,22 \pm 0,85$ & $2,09 *$ & 23 & - & - & - & 11 \\
\hline okt. 10 . & - & - & - & 1 & - & - & - & 0 \\
\hline okt. 29. & - & - & - & 0 & - & - & - & 0 \\
\hline nov. 6. & - & - & - & 0 & - & - & - & 0 \\
\hline
\end{tabular}

n.sz. $0,05<\mathrm{p} ; * 0,01<\mathrm{p}<0,05 ; * * 0,001<\mathrm{p}<0,01 ; * * * \mathrm{p}<0,001$ 
A litéri fenyvesben az A. subterranea és a L. emarginatus fajok kolóniái a felvételezési napok többségén szignifikánsan több dolgozót mobilizáltak a tonhalra, míg ezzel szemben a Temnothorax-fajok esetében rendszerint nem volt kimutatható szignifikáns különbség a kétféle csali preferenciájában (25. táblázat). Eltérően a többi fajtól, mind a F. fusca, mind a F. gagates táplálékpreferenciája viszonylag jelentős szezonális változást mutatott, ez azonban a két faj egyikének esetében sem követett határozott trendet.

Az előző élőhelyhez hasonlóan az A. subterranea kivételével, amelynél a táplálkozó egyedek relatív aránya a tonhalon jelentősen nagyobb volt, az egyes gyakoribb fajok a mézen szignifikánsan nagyobb táplálkozási hatékonyságot mutattak (26. táblázat).

Táplálkozási hatékonyságukat tekintve az egyes fajok mind a méz-méz, mind a tonhaltonhal összehasonlításban szignifikánsan különböztek egymástól (Kruskal-Wallis próba, méz: $\chi^{2}=375,45 ; \quad \mathrm{df}=4 ; \mathrm{p}<0,001 ; \quad$ tonhal: $\left.\chi^{2}=41,44 ; \mathrm{df}=4 ; \mathrm{p}<0,001\right) ;$ összességében a legnagyobb táplálkozási hatékonyság a két Serviformica-fajt, míg a legkisebb az A. subterraneát jellemezte (26. táblázat, Függelék 10. táblázat).

26. táblázat. A gyakoribb fajok táplálkozási hatékonysága (a táplálkozó egyedek és az összes egyed hányadosának átlaga a szórással) a kétféle táplálékforráson a litéri fenyvesben. A Mann-Whitney U-teszt alapján egymástól szignifikánsan különböző $(\mathrm{p}<0,05)$ fajokat különböző betüjelek jelölik.

\begin{tabular}{lccccc}
\hline & méz & $\mathrm{n}$ & tonhal & $\mathrm{n}$ & Mann-Whitney z \\
\cline { 2 - 6 } Formica fusca & $\mathbf{0 , 8 0} \pm \mathbf{0 , 3 6} \mathbf{3}^{\mathrm{a}}$ & 719 & $0,60 \pm 0,43^{\mathrm{a}}$ & 827 & $-9,95^{* * *}$ \\
Formica gagates & $\mathbf{0 , 8 5} \pm \mathbf{0 , 2 7} 7^{\mathrm{a}}$ & 163 & $0,62 \pm 0,34^{\mathrm{ab}}$ & 141 & $-7,00^{* * *}$ \\
Lasius emarginatus & $\mathbf{0 , 6 7} \pm \mathbf{0 , 3 5} 5^{\mathrm{b}}$ & 227 & $0,58 \pm 0,29^{\mathrm{b}}$ & 272 & $-4,50^{* * *}$ \\
Temnothorax spp. & $\mathbf{0 , 6 4} \pm \mathbf{0 , 4 2} \mathbf{2}^{\mathrm{b}}$ & 356 & $0,52 \pm 0,44^{\mathrm{bc}}$ & 305 & $-3,28^{* * *}$ \\
Aphaenogaster subterranea & $0,46 \pm 0,32^{\mathrm{c}}$ & 467 & $\mathbf{0 , 5 2} \pm \mathbf{0 , 3 1 ^ { \mathrm { c } }}$ & 597 & $-2,72^{* *}$ \\
\hline
\end{tabular}

n.sz. $0,05<\mathrm{p} ; * 0,01<\mathrm{p}<0,05 ; * * 0,001<\mathrm{p}<0,01 ; * * * \mathrm{p}<0,001$

\section{Térbeli elkülönülés II.}

A füredi tölgyesben a csalétkeket látogató gyakoribb fajok között szignifikáns különbség mutatkozott a tekintetben, hogy a csalétkeken milyen mértékben osztoztak más hangyafajokkal (Khi-négyzet próba, $\chi^{2}=1298,40 ; \mathrm{df}=3 ; \mathrm{p}<0,001$ ); míg a $P$. nitens többnyire egyedüli fajként, addig a $F$.gagates és Temnothorax-fajok rendszerint más hangyafajok képviselőivel együtt fordultak elő a csalétkeken (27. táblázat). 
25. táblázat. A gyakoribb fajok csalétkeken mutatott szezonális táplálékpreferenciája (átlagegyedszám a szórással a kétféle táplálékforráson) a litéri fenyvesben.

\begin{tabular}{|c|c|c|c|c|c|c|c|c|c|c|}
\hline & \multicolumn{4}{|c|}{ A. subterranea } & \multicolumn{4}{|l|}{ F. fusca } & \multicolumn{2}{|c|}{ Temnothorax spp. } \\
\hline & méz & tonhal & Wilcoxon z & $\mathrm{n}$ & méz & tonhal & Wilcoxon z & $\mathrm{n}$ & méz & tonhal \\
\hline ápr. 18. & - & - & - & 4 & $1,23 \pm 0,85$ & $0,17 \pm 0,38$ & $5,08 * * *$ & 60 & $1,82 \pm 2,42$ & $1,40 \pm 1,6$ \\
\hline ápr. 23. & $0,91 \pm 1,41$ & $3,32 \pm 3,34$ & $3,34 * * *$ & 22 & $1,83 \pm 1,59$ & $0,03 \pm 0,18$ & $6,59 * * *$ & 59 & $1,82 \pm 1,81$ & $1,75 \pm 1,8$ \\
\hline máj. 10. & $1,48 \pm 2,79$ & $4,52 \pm 4,90$ & $4,84 * * *$ & 46 & $2,92 \pm 3,12$ & $2,42 \pm 3,00$ & 1,24 n.sz. & 171 & $1,83 \pm 1,92$ & $1,43 \pm 1,6$ \\
\hline jún. 13. & $6,67 \pm 6,79$ & $13,35 \pm 13,28$ & $5,04 * * *$ & 91 & $0,54 \pm 0,86$ & $1,05 \pm 0,79$ & $3,07 * *$ & 84 & $0,56 \pm 0,64$ & $0,59 \pm 0,5$ \\
\hline jún. 21. & $2,85 \pm 5,56$ & $6,59 \pm 6,02$ & $5,58 * * *$ & 94 & $0,20 \pm 0,40$ & $1,30 \pm 0,84$ & $7,65^{* * *}$ & 124 & $0,53 \pm 0,52$ & $0,47 \pm 0,5$ \\
\hline júl. 4. & $5,77 \pm 5,32$ & $7,70 \pm 5,23$ & $5,30 * * *$ & 111 & $1,55 \pm 1,66$ & $0,86 \pm 0,96$ & $2,78 * *$ & 135 & $1,09 \pm 1,13$ & $0,73 \pm 1,1$ \\
\hline aug. 15 . & $3,88 \pm 3,93$ & $4,50 \pm 5,94$ & 0,54 n.sz. & 104 & $0,99 \pm 1,66$ & $1,68 \pm 1,75$ & $4,10 * * *$ & 164 & $0,88 \pm 0,74$ & $0,63 \pm 0,7$ \\
\hline aug. 22 . & $6,31 \pm 6,77$ & $8,82 \pm 9,69$ & $2,36^{*}$ & 88 & $1,73 \pm 2,59$ & $1,87 \pm 2,18$ & 1,46 n.sz. & 182 & - & - \\
\hline szept. 4. & $5,54 \pm 9,87$ & $9,42 \pm 10,90$ & $4,73^{* * *}$ & 67 & $0,99 \pm 1,13$ & $1,02 \pm 0,99$ & 1,22 n.sz. & 113 & $1,40 \pm 1,85$ & $0,63 \pm 0,8$ \\
\hline okt. 3. & $0,72 \pm 0,84$ & $2,96 \pm 2,94$ & $2,87 * *$ & 25 & $0,46 \pm 0,71$ & $1,50 \pm 1,27$ & $5,52 * * *$ & 82 & - & - \\
\hline okt. 17. & - & - & - & 1 & - & - & - & 7 & - & - \\
\hline \multirow[t]{15}{*}{ okt. 31.} & $2,00 \pm 3,51$ & $2,31 \pm 2,06$ & 0,85 n.sz. & 13 & - & - & - & 1 & - & - \\
\hline & & \multicolumn{5}{|c|}{ L. emarginatus } & F. gagates & & & \\
\hline & & & méz & tonhal & Wilcoxon & $\mathrm{zz}$ & méz & tonhal & Wilcoxon $\mathrm{z}$ & $\mathrm{n}$ \\
\hline & & ápr. 18. & $6,61 \pm 5,50$ & $6,35 \pm 5,80$ & 0,77 n.sz. & 23 & $3,33 \pm 4,14$ & $0,15 \pm 0,46$ & $4,35^{* * *}$ & 27 \\
\hline & & ápr. 23. & $10,16 \pm 9,28$ & $2,70 \pm 3,38$ & $5,46 * * *$ & 44 & $1,27 \pm 0,77$ & $0,27 \pm 0,63$ & $3,41 * * *$ & 22 \\
\hline & & máj. 10. & $3,00 \pm 2,55$ & $20,18 \pm 11,85$ & $4,99 * * *$ & 33 & $9,10 \pm 9,40$ & $9,87 \pm 9,19$ & 0,11 n.sz. & 30 \\
\hline & & jún. 13. & $3,12 \pm 4,53$ & $11,78 \pm 9,61$ & $7,16^{* * *}$ & 86 & $3,68 \pm 3,76$ & $6,73 \pm 5,96$ & $3,13 * *$ & 22 \\
\hline & & jún. 21. & $1,20 \pm 2,32$ & $5,54 \pm 7,86$ & $5,30 * * *$ & 50 & $0,53 \pm 0,77$ & $2,26 \pm 1,79$ & $2,97 * *$ & 19 \\
\hline & & júl. 4. & $1,50 \pm 1,80$ & $3,82 \pm 3,45$ & $4,84 * * *$ & 50 & $4,64 \pm 3,74$ & $2,11 \pm 2,12$ & $3,93 * * *$ & 36 \\
\hline & & aug. 15 . & - & - & - & 6 & - & - & - & 0 \\
\hline & & aug. 22 . & $8,09 \pm 4,09$ & $13,45 \pm 6,52$ & $2,49^{*}$ & 11 & $4,34 \pm 3,68$ & $3,44 \pm 3,02$ & 1,12 n.sz. & 32 \\
\hline & & szept. 4. & - & - & - & 0 & - & - & - & 10 \\
\hline & & okt. 3. & - & - & - & 0 & - & - & - & 0 \\
\hline & & okt. 17. & - & - & - & 0 & - & - & - & 5 \\
\hline & & okt. 31 . & - & - & - & 0 & - & - & - & 0 \\
\hline
\end{tabular}

n.sz. $0,05<\mathrm{p} ; * 0,01<\mathrm{p}<0,05 ; * * 0,001<\mathrm{p}<0,01 ; * * * \mathrm{p}<0,001$ 
27. táblázat. A látogatott csalétkek megoszlása a gyakoribb fajok esetében a más fajokkal való együttes jelenlét vagy annak hiánya alapján a füredi tölgyesben. A Khi-négyzet próba alapján egymástól szignifikánsan különböző $(\mathrm{p}<0,05)$ fajokat különböző betüjelek jelölik.

\begin{tabular}{lccc}
\hline & egyedül & más fajjal/fajokkal & $\chi^{2}$-próba \\
Prenolepis nitens & 0,86 & 0,14 & $\mathrm{~A}$ \\
Aphaenogaster subterranea & 0,47 & 0,53 & $\mathrm{~B}$ \\
Formica gagates & 0,26 & 0,74 & $\mathrm{C}$ \\
Temnothorax spp. & 0,10 & 0,90 & $\mathrm{D}$ \\
\hline
\end{tabular}

Az egyes fajpárok csalétkeken való együttes elöfordulásának mértéke a legtöbb esetben szignifikánsan különbözött a véletlenszerütöl (28. táblázat). A két leggyakoribb faj, az A. subterranea és a $P$.nitens, valamint a $F$. gagates és a $P$.nitens többnyire jelentös szegregációt mutatott a csalétkeken, míg ezzel szemben az A. subterranea és a Temnothoraxfajok, ill. a $F$. gagates és utóbbiak esetében a csalétkeken való együttes előfordulás mértéke rendszerint a vártnál szignifikánsan nagyobb volt.

28. táblázat. A csalétkeken való együttes előfordulás mértéke a gyakoribb fajpárokra a füredi tölgyesben (azokban az időszakokban, amikor az egyes fajpárok mindkét tagja viszonylag nagyobb aktivitást mutatott). $\mathrm{SE}_{(\mathrm{M})}, \mathrm{SE}_{(\mathrm{V})}$ : a megfigyelt, ill. a véletlen eloszlás esetén várható C-score értékek. A vártnál szignifikánsabb kisebb értékek aggregálódást, míg az annál nagyobb értékek az illető fajok szegregálódását jelzik a csalétkeken. ApSu: Aphaenogaster subterranea; PrNi: Prenolepis nitens; Te: Temnothorax spp.; FoGa: Formica gagates.

\begin{tabular}{llcccccccc}
\hline \multirow{4}{*}{ ApSu-PrNi } & & $\mathrm{SE}_{(\mathrm{M})}$ & $\mathrm{SE}_{(\mathrm{V})}$ & $\mathrm{p}$ & & & $\mathrm{SE}_{(\mathrm{M})}$ & $\mathrm{SE}_{(\mathrm{V})}$ & $\mathrm{p}$ \\
& aug. 12. & $\mathbf{7 8 6 5}$ & 5393 & $<0,001$ & PrNi-Te & ápr. 3. & 2236 & $\mathbf{3 8 9 0}$ & $<0,01$ \\
& aug. 29. & 3626 & 3043 & n.sz. & & ápr. 17. & 1110 & $\mathbf{3 8 4 7}$ & $<0,001$ \\
& szept. 10. & $\mathbf{7 0 6 8}$ & 4609 & $<0,001$ & & máj. 7. & $\mathbf{3 4 4 5}$ & 1828 & $<0,01$ \\
ApSu-Te & & & & & & aug. 12. & $\mathbf{5 5 6 6}$ & 4433 & $<0,05$ \\
& jún. 18. & 5832 & $\mathbf{7 7 5 5}$ & $<0,01$ & & aug. 29. & 1833 & 2029 & n.sz. \\
& jún. 27. & 2652 & $\mathbf{6 5 9 0}$ & $<0,001$ & & szept. 10. & 2176 & 1808 & n.sz. \\
& júl. 10. & 3330 & $\mathbf{7 2 5 2}$ & $<0,001$ & & & & & \\
& aug. 12. & 416 & $\mathbf{3 3 0 1}$ & $<0,001$ & PrNi-FoGa & ápr. 3. & $\mathbf{3 7 6 2}$ & 2544 & $<0,05$ \\
& aug. 29. & 430 & $\mathbf{2 6 9 2}$ & $<0,001$ & & ápr. 17. & 1125 & 1115 & n.sz. \\
ApSu-FoGa & jún. 18. & $\mathbf{4 6 3 2}$ & 2791 & $<0,01$ & FoGa-Te & ápr. 3. & 741 & $\mathbf{1 3 0 1}$ & $<0,001$ \\
& szept. 10. & 540 & $\mathbf{1 1 7 9}$ & $<0,001$ & & máj. 7. & $\mathbf{6 6 7 2}$ & 1726 & $<0,001$ \\
& jún. 27. & 1476 & 1942 & n.sz. & & ápr. 17. & 572 & 629 & n.sz. \\
& júl. 10. & 2822 & 2179 & n.sz. & & máj. 7. & 360 & $\mathbf{9 0 1}$ & $<0,001$ \\
& & & & & & jún. 18. & 1116 & $\mathbf{2 7 7 7}$ & $<0,001$ \\
& & & & & & jún. 27. & 1092 & $\mathbf{1 5 7 7}$ & $<0,05$ \\
& & & & & & júl. 10. & 1417 & 1950 & n.sz. \\
\hline
\end{tabular}

A litéri fenyves gyakoribb fajai bár összességében ugyancsak szignifikánsan különböztek egymástól a tekintetben, hogy a csalétkeken egyedül vagy más hangyafajokkal együtt fordultak elő nagyobb arányban (Khi-négyzet próba, $\chi^{2}=165,22 ; \mathrm{df}=4 ; \mathrm{p}<0,001$ ), ugyanakkor a közöttük lévő eltérések az előző élőhely fajainak esetében tapasztaltakhoz 
képest jelentősen kisebbek voltak (29. táblázat). A Temnothorax-fajok kivételével, amelyek rendszerint más hangyafajok képviselőivel osztoztak a táplálékforráson, a gyakoribb fajok az esetek nagyobb részében egyedül látogatták a csalétkeket.

29. táblázat. A látogatott csalétkek megoszlása a gyakoribb fajok esetében a más fajokkal való együttes jelenlét vagy annak hiánya alapján a litéri fenyvesben. A Khi-négyzet próba alapján egymástól szignifikánsan különböző $(p<0,05)$ fajokat különböző betüjelek jelölik.

\begin{tabular}{lccc}
\hline & egyedül & más fajjal/fajokkal & $\chi^{2}$-próba \\
Lasius emarginatus & 0,77 & 0,23 & $\mathrm{~A}$ \\
Formica gagates & 0,66 & 0,34 & $\mathrm{AB}$ \\
Formica fusca & 0,61 & 0,39 & $\mathrm{~B}$ \\
Aphaenogaster subterranea & 0,59 & 0,41 & $\mathrm{~B}$ \\
Temnothorax spp. & 0,34 & 0,66 & $\mathrm{C}$ \\
\hline
\end{tabular}

$\mathrm{Az}$ egyes fajpárok csalétkeken való együttes előfordulásának mértéke a füredi tölgyestől eltérően mindössze az esetek felében különbözött szignifikánsan a véletlenszerütől (30. táblázat). Míg szignifikáns térbeli aggregáció csupán néhány esetben, a két Serviformicafaj és a Temnothorax-fajok között volt kimutatható, addig az A. subterranea, L. emarginatus és F. gagates, a két Serviformica-faj, valamint a L. emarginatus és a Temnothorax-fajok több esetben is jelentős szegregációt mutattak a csalétkeken.

30. táblázat. A csalétkeken való együttes előfordulás mértéke a gyakoribb fajpárokra a litéri fenyvesben (azokban az időszakokban, amikor az egyes fajpárok mindkét tagja viszonylag nagyobb aktivitást mutatott). $\mathrm{SE}_{(\mathrm{M})}, \mathrm{SE}_{(\mathrm{V})}$ : a megfigyelt, ill. a véletlen eloszlás esetén várható $\mathrm{C}$-score értékek. A vártnál szignifikánsabb kisebb értékek aggregálódást, míg az annál nagyobb értékek az illető fajok szegregálódását jelzik a csalétkeken. ApSu: Aphaenogaster subterranea; FoFu: Formica fusca; Te: Temnothorax spp.; LaEm: Lasius emarginatus; FoGa: Formica gagates.

\begin{tabular}{llcccccccc}
\hline \multirow{5}{*}{ ApSu-FoFu } & & $\mathrm{SE}_{(\mathrm{M})}$ & $\mathrm{SE}_{(\mathrm{V})}$ & $\mathrm{p}$ & & & $\mathrm{SE}_{(\mathrm{M})}$ & $\mathrm{SE}_{(\mathrm{V})}$ & $\mathrm{p}$ \\
& jún. 13. & 4278 & 4388 & n.sz. & FoFu-LaEm & ápr. 18. & 1218 & 1080 & n.sz. \\
& jún. 21. & 4959 & 5662 & n.sz. & & ápr. 23. & $\mathbf{2 2 9 6}$ & 1910 & $<0,05$ \\
& júl. 4. & $\mathbf{8 6 9 2}$ & 6498 & $<0,01$ & máj. 10. & $\mathbf{5 0 4 0}$ & 2690 & $<0,001$ \\
& aug. 15. & $\mathbf{8 1 2 5}$ & 6620 & $<0,05$ & jún. 13. & 4899 & 4225 & n.sz. \\
& aug. 22. & 6816 & 6013 & n.sz. & jún. 21. & 3815 & 3493 & n.sz. \\
& szept. 4. & 4800 & 4251 & n.sz. & & júl. 4. & 3306 & 3651 & n.sz. \\
ApSu-Te & & & & & & & & & \\
& jún. 13. & 1785 & 1703 & n.sz. & FoFu-FoGa & ápr. 18. & 1368 & 1255 & n.sz. \\
& jún. 21. & 890 & 1001 & n.sz. & & ápr. 23. & 1140 & 1023 & n.sz. \\
& júl. 4. & 2448 & 2296 & n.sz. & & máj. 10. & $\mathbf{5 1 3 0}$ & 2479 & $<0,001$ \\
& aug. 15. & 1536 & 1661 & n.sz. & & jún. 13. & $\mathbf{1 8 4 8}$ & 1332 & $<0,01$ \\
& aug. 22. & 595 & 649 & n.sz. & & jún. 21. & 1800 & 1469 & n.sz. \\
& szept. 4. & $\mathbf{2 0 1 0}$ & 1504 & $<0,01$ & & júl. 4. & $\mathbf{4 5 2 2}$ & 2740 & $<0,001$ \\
\hline
\end{tabular}




\begin{tabular}{llcccccccc}
\hline \multirow{5}{*}{ ApSu-LaEm } & & $\mathrm{SE}_{(\mathrm{M})}$ & $\mathrm{SE}_{(\mathrm{V})}$ & $\mathrm{p}$ & & & $\mathrm{SE}_{(\mathrm{M})}$ & $\mathrm{SE}_{(\mathrm{V})}$ & $\mathrm{p}$ \\
& jún. 13. & $\mathbf{7 6 5 0}$ & 4462 & $<0,001$ & $\mathrm{Te}-L a E m$ & ápr. 18. & $\mathbf{2 8 7 5}$ & 1758 & $<0,001$ \\
& jún. 21. & $\mathbf{4 7 0 0}$ & 2998 & $<0,001$ & & ápr. 23. & $\mathbf{4 4 6 9}$ & 2979 & $<0,001$ \\
& júl. 4. & $\mathbf{5 3 9 0}$ & 3320 & $<0,001$ & & máj. 10. & $\mathbf{3 7 9 5}$ & 2350 & $<0,001$ \\
\multirow{5}{*}{ ApSu-FoGa } & & & & & & jún. 13. & 1886 & 1634 & n.sz. \\
& jún. 13. & 1672 & 1410 & n.sz. & & jún. 21. & 750 & 621 & n.sz. \\
& jún. 21. & $\mathbf{1 6 7 4}$ & 1253 & $<0,05$ & & júl. 4. & $\mathbf{1 5 6 8}$ & 1295 & $<0,05$ \\
& júl. 4. & $\mathbf{3 8 5 0}$ & 2496 & $<0,001$ & & & & & \\
FoFu-Te & & & & Te-FoGa & ápr. 18. & 624 & $\mathbf{2 0 5 1}$ & $<0,001$ \\
& ápr. 18. & 4494 & 4100 & n.sz. & & ápr. 23. & 1111 & $\mathbf{1 5 9 2}$ & $<0,05$ \\
& ápr. 23. & 3204 & 3813 & n.sz. & & máj. 10. & $\mathbf{2 7 5 0}$ & 2164 & $<0,05$ \\
& máj. 10. & 4841 & $\mathbf{7 0 4 5}$ & $<0,01$ & & jún. 13. & 336 & $\mathbf{5 1 6}$ & $<0,01$ \\
& jún. 13. & 1638 & 1613 & n.sz. & & jún. 21. & 252 & 259 & n.sz. \\
& jún. 21. & 1190 & 1170 & n.sz. & & júl. 4. & $\mathbf{1 1 8 8}$ & 975 & $<0,05$ \\
& júl. 4. & 2023 & 2528 & n.sz. & & & & & \\
& aug. 15. & 1029 & $\mathbf{2 0 0 5}$ & $<0,01$ & LaEm-FoGa & ápr. 18. & 621 & 537 & n.sz. \\
& aug. 22. & 885 & 877 & n.sz. & & ápr. 23. & 968 & 800 & n.sz. \\
& szept. 4. & 1584 & 2137 & n.sz. & & máj. 10. & 868 & 826 & n.sz. \\
& & & & & jún. 13. & $\mathbf{1 8 9 2}$ & 1356 & $<0,01$ \\
& & & & & & jún. 21. & $\mathbf{9 5 0}$ & 775 & $<0,05$ \\
& & & & & & júl. 4. & $\mathbf{1 8 0 0}$ & 1399 & $<0,01$ \\
\hline
\end{tabular}

Interspecifikus interakciók

A csalétkeken mutatott interspecifikus interakcióik tekintetében a füredi tölgyes gyakoribb ( $\geq 10$ kizárással végződő interakcióban résztvevő) fajai között szignifikáns különbség volt kimutatható (Khi-négyzet próba, $\chi^{2}=342,36 ; \mathrm{df}=9 ; \mathrm{p}<0,001$ ); míg az A. subterranea és a $P$. nitens esetében a kizárások, ill. a kizáráshoz nem vezető agresszív megnyilvánulások közel negyedét tették ki az összes megfigyelt interakciónak, addig a $F$. gagates és a Temnothorax-fajok többnyire nem konfrontálódtak más fajokkal, a fennmaradó esetek többségében pedig menekülni kényszerültek a csalétkekről (31. táblázat).

A csalétkekről való kizáráshoz nem vezető agresszív interakciók többségére a két leggyakoribb faj, az A. subterranea és a $P$. nitens részvételével került sor (32. táblázat). Előbbinél az agresszív megnyilvánulások döntő többsége más fajok egyedei ellen, míg utóbbinál javarészt a konspecifikus idegen kolóniák tagjai ellen irányult.

A legtöbb, többnyire agresszív kizárás az A. subterraneához volt köthető, míg a csalétkekről leggyakrabban kizárt fajok a Temnothorax-fajok voltak (33. táblázat). 
31. táblázat. A csalétkeken megfigyelt interspecifikus interakciók a gyakoribb ( $\geq 10$ kizárással végződő interakcióban résztvevő) fajokra a füredi tölgyesben. A kizárásnál és menekülésnél az egyes cellákban az összes kizárásra/menekülésre, zárójelben pedig kizárólag az agresszív kizárásra, ill. az ebből fakadó menekülésre vonatkozó értékek láthatók. A Khi-négyzet próba alapján egymástól szignifikánsan különböző $(\mathrm{p}<0,05)$ fajokat különböző betüjelek jelölik. PrNi: Prenolepis nitens; ApSu: Aphaenogaster subterranea; FoGa: Formica gagates; Te: Temnothorax spp.; n: megfigyelések száma.

\begin{tabular}{|c|c|c|c|c|c|c|}
\hline \multirow[b]{2}{*}{ Fajok } & \multicolumn{5}{|c|}{ Interakciók } & \multirow[b]{2}{*}{$\chi^{2}$-próba } \\
\hline & $\begin{array}{c}\text { Koegzisztencia }^{1} \\
(\mathrm{p} \%)\end{array}$ & $\begin{array}{c}\text { Agresszió }^{2} \\
(\mathrm{p} \%)\end{array}$ & $\begin{array}{c}\text { Kizárás }^{3} \\
(\mathrm{p} \%)\end{array}$ & $\begin{array}{c}\text { Menekülés } \\
(\mathrm{p} \%)\end{array}$ & $\mathrm{n}$ & \\
\hline PrNi & 0,55 & 0,18 & $0,20(0,13)$ & $0,08(0,07)$ & 245 & A \\
\hline $\mathrm{ApSu}$ & 0,58 & 0,12 & $0,27(0,18)$ & $0,05(0,04)$ & 438 & A \\
\hline FoGa & 0,71 & 0,05 & $0,05(0,04)$ & $0,20(0,17)$ & 133 & B \\
\hline $\mathrm{Te}$ & 0,82 & 0,002 & $0,00(0,00)$ & $0,18(0,12)$ & 588 & $\mathrm{C}$ \\
\hline
\end{tabular}

${ }^{1}$ Más faj(ok)/kolóniák egyedeivel való konfrontációmentes együttes jelenlét a csalétken.

${ }^{2}$ A csalétekröl való kizáráshoz nem vezető, kölcsönös agresszióval (pl. harccal) vagy azzal nem járó bármilyen agresszív megnyilvánulás (pl. harapás, méreg-/riasztóanyag kibocsátása, stb.).

${ }^{3}$ Egy másik faj/kolónia egyedének/egyedeinek kizárása a csalétekröl passzív vagy agresszív módon.

${ }^{4}$ Egy másik faj/kolónia egyedének/egyedeinek jelenléte vagy agresszív megnyilvánulása által kiváltott menekülés a csalétekről.

32. táblázat. A csalétkeken megfigyelt, kizáráshoz nem vezető agresszív megnyilvánulások a füredi tölgyesben. Az egyes sorokban a támadó, az oszlopokban pedig a megtámadott fajok láthatók. Az egyes cellákban szereplő számok azon egyperces megfigyelések számát jelölik, amelyeknél agresszív megnyilvánulás (nem kölcsönös agresszió/kölcsönös agresszió) volt regisztrálható.

\begin{tabular}{lcccccc|c}
\hline támadó/megtámadott & $\mathrm{ApSu}$ & $\mathrm{PrNi}$ & $\mathrm{Te}$ & $\mathrm{FoGa}$ & $\mathrm{LaBr}$ & $\mathrm{LiMi}$ & Össz.: \\
\hline Aphaenogaster subterranea & $1 / 7$ & $2 / 8$ & $19 / 0$ & $3 / 4$ & $1 / 4$ & $0 / 5$ & $\mathbf{2 6 / 2 8}$ \\
Prenolepis nitens & $1 / 8$ & $1 / 28$ & $1 / 0$ & $1 / 2$ & - & $0 / 1$ & $\mathbf{4 / 3 9}$ \\
Temnothorax spp. & - & - & $0 / 1$ & - & - & - & $0 / 1$ \\
Formica gagates & $0 / 4$ & $1 / 2$ & - & - & $0 / 1$ & - & $1 / 7$ \\
Lasius brunneus & $3 / 4$ & - & - & $0 / 1$ & - & - & $3 / 5$ \\
Liometopum microcephalum & $0 / 5$ & $0 / 1$ & - & - & - & - & $0 / 6$ \\
\hline Összesen: & $\mathbf{5 / 2 8}$ & $\mathbf{4 / 3 9}$ & $20 / 1$ & $4 / 7$ & $1 / 5$ & $0 / 6$ & $34 / 86$ \\
\hline
\end{tabular}

33. táblázat. A csalétkekről való kizárások száma a füredi tölgyesben. Az egyes sorokban a kizáró, az oszlopokban pedig a kizárt fajok láthatók. Az egyes cellákban szereplő számok azon egyperces megfigyelések számát jelölik, amelyeknél kizárás (nem agresszív kizárás/agresszív kizárás) volt regisztrálható.

\begin{tabular}{lcccccccc|c}
\hline kizáró/kizárt & $\mathrm{ApSu}$ & $\mathrm{PrNi}$ & $\mathrm{Te}$ & $\mathrm{FoGa}$ & $\mathrm{LaBr}$ & $\mathrm{CrSm}$ & $\mathrm{CaTr}$ & $\mathrm{LiMi}$ & Össz.: \\
\hline Aphaenogaster subterranea & $0 / 8$ & $1 / 5$ & $28 / 58$ & $1 / 14$ & $0 / 2$ & - & - & - & $\mathbf{3 0 / 8 7}$ \\
Prenolepis nitens & $2 / 4$ & $0 / 12$ & $10 / 8$ & $3 / 8$ & - & - & $1 / 0$ & - & $16 / 32$ \\
Temnothorax spp. & - & - & - & - & - & - & - & - & - \\
Formica gagates & $1 / 3$ & $0 / 1$ & $0 / 1$ & - & - & - & - & - & $1 / 5$ \\
Lasius brunneus & $0 / 1$ & - & - & $0 / 1$ & - & - & - & - & $0 / 2$ \\
Crematogaster schmidti & $0 / 2$ & - & $0 / 1$ & - & - & - & - & - & $0 / 3$ \\
Camponotus truncatus & - & - & - & - & - & - & - & - & - \\
Liometopum microcephalum & - & - & $0 / 1$ & - & - & - & - & - & $0 / 1$ \\
\hline Összesen: & $3 / 18$ & $1 / 18$ & $\mathbf{3 8 / 6 9}$ & $4 / 23$ & $0 / 2$ & - & $1 / 0$ & - & $47 / 130$ \\
\hline
\end{tabular}


Az egyes fajok a „győzelemmel” végző interakcióik relatív arányában szignifikánsan különböztek egymástól (Khi-négyzet próba, $\chi^{2}=203,29$; df=3; p<0,001); arányaiban a legtöbb kizárás (legnagyobb dominancia index) az A. subterraneát és a $P$. nitenst, a legkevesebb (legkisebb dominancia index) pedig a Temnothorax-fajokat jellemezte (34. táblázat). Míg a dominancia mértéke és a csalétkek felfedezési ideje között erős negatív korreláció volt kimutatható, addig előbbi és az egyes fajokra jellemző többi releváns változó nem mutatott szignifikáns összefüggést (Függelék 11., 13. táblázat).

A dominancia-hierarchia linearitása az inkonzisztenciák (azaz az intranzitív interakciók) hiánya ellenére nem különbözött szignifikánsan a véletlenszerütől (h'=0,47; p=0,25) (Függelék 14. táblázat).

34. táblázat. A dominancia rangsorrendje a gyakoribb ( $\geq 10$ kizárással végződő interakcióban résztvevő) fajokra a füredi tölgyesben. A Khi-négyzet próba alapján egymástól szignifikánsan különböző $(p<0,05)$ fajokat különböző betüjelek jelölik. DI: dominancia index; n: megfigyelések száma.

\begin{tabular}{lccc}
\hline Fajok & $\mathrm{DI}^{\dagger}$ & $\mathrm{n}$ & $\chi^{2}$-próba \\
Aphaenogaster subterranea & 0,85 & 138 & $\mathrm{~A}$ \\
Prenolepis nitens & 0,72 & 67 & $\mathrm{~A}$ \\
Formica gagates & 0,18 & 33 & $\mathrm{~B}$ \\
Temnothorax spp. & 0,00 & 107 & $\mathrm{C}$ \\
\hline †Azon interakciók gyakorisága, & melyekből az & illető faj \\
„győztesként” került ki (tkp. a kizárások és az összes \\
kizárással/meneküléssel járó interakció hányadosa).
\end{tabular}

35. táblázat. A csalétkeken megfigyelt interspecifikus interakciók a gyakoribb ( $\geq 10$ kizárással végződő interakcióban résztvevő) fajokra a litéri fenyvesben. A kizárásnál és menekülésnél az egyes cellákban az összes kizárásra/menekülésre, zárójelben pedig kizárólag az agresszív kizárásra, ill. az ebből fakadó menekülésre vonatkozó értékek láthatók. A Khi-négyzet próba alapján egymástól szignifikánsan különböző $(\mathrm{p}<0,05)$ fajokat különböző betüjelek jelölik. ApSu: Aphaenogaster subterranea; LaEm: Lasius emarginatus; CaLi: Camponotus ligniperdus; FoFu: Formica fusca; MySa: Myrmica sabuleti; Te: Temnothorax spp.; n: megfigyelések száma.

\begin{tabular}{|c|c|c|c|c|c|c|}
\hline \multirow[b]{2}{*}{ Fajok } & \multicolumn{5}{|c|}{ Interakciók } & \multirow[b]{2}{*}{$\chi^{2}$-próba } \\
\hline & $\begin{array}{c}\text { Koegzisztencia }^{1} \\
(\mathrm{p} \%)\end{array}$ & $\begin{array}{c}\text { Agresszió }^{2} \\
(\mathrm{p} \%)\end{array}$ & $\begin{array}{c}\text { Kizárás }^{3} \\
(\mathrm{p} \%)\end{array}$ & $\begin{array}{c}\text { Menekülés } \\
(\mathrm{p} \%)\end{array}$ & $\mathrm{n}$ & \\
\hline $\mathrm{ApSu}$ & 0,55 & 0,09 & $0,32(0,21)$ & $0,04(0,01)$ & 270 & A \\
\hline LaEm & 0,58 & 0,14 & $0,28(0,20)$ & $0,00(0,00)$ & 71 & A \\
\hline $\mathrm{CaLi}$ & 0,70 & 0,03 & $0,27(0,13)$ & $0,00(0,00)$ & 70 & A \\
\hline $\mathrm{FoFu}$ & 0,71 & 0,01 & $0,02(0,004)$ & $0,26(0,16)$ & 459 & B \\
\hline MySa & 0,82 & 0,01 & $0,13(0,06)$ & $0,04(0,04)$ & 72 & $\mathrm{C}$ \\
\hline $\mathrm{Te}$ & 0,95 & 0,003 & $0,003(0,003)$ & $0,05(0,02)$ & 322 & $\mathrm{D}$ \\
\hline
\end{tabular}

${ }^{1}$ Más faj(ok)/kolóniák egyedeivel való konfrontációmentes együttes jelenlét a csalétken.

${ }^{2}$ A csalétekről való kizáráshoz nem vezető, kölcsönös agresszióval (pl. harccal) vagy azzal nem járó bármilyen agresszív megnyilvánulás (pl. harapás, méreg-/riasztóanyag kibocsátása, stb.).

${ }^{3}$ Egy másik faj/kolónia egyedének/egyedeinek kizárása a csalétekről passzív vagy agresszív módon.

${ }^{4}$ Egy másik faj/kolónia egyedének/egyedeinek jelenléte vagy agresszív megnyilvánulása által kiváltott menekülés a csalétekröl. 
Az előző élőhelyhez hasonlóan a litéri fenyves gyakoribb fajai a csalétkeken mutatott interspecifikus interakcióik tekintetében ugyancsak szignifikánsan különböztek egymástól (Khi-négyzet próba, $\chi^{2}=436,38 ; \mathrm{df}=15 ; \mathrm{p}<0,001$ ); míg az A. subterranea, L. emarginatus és C. ligniperdus esetében a kizárások, a $F$. fusca esetében pedig a menekülések közel harmadát tették ki az összes megfigyelt interakciónak, addig a M. sabuleti és a Temnothorax-fajok csupán az esetek kis százalékában konfrontálódtak más fajokkal (35. táblázat).

Mind a legtöbb, kizáráshoz nem vezető agresszív megnyilvánulás, mind a legtöbb kizárás az A. subterranea esetében volt megfigyelhetö, míg a leggyakrabban támadást elszenvedő, ill. csalétekről kizárt faj a $F$. fusca volt (36-37. táblázat).

36. táblázat. A csalétkeken megfigyelt, kizáráshoz nem vezető agresszív megnyilvánulások a litéri fenyvesben. Az egyes sorokban a támadó, az oszlopokban pedig a megtámadott fajok láthatók. Az egyes cellákban szereplő számok azon egyperces megfigyelések számát jelölik, amelyeknél agresszív megnyilvánulás (nem kölcsönös agresszió/kölcsönös agresszió) volt regisztrálható.

\begin{tabular}{lcccccccc|c}
\hline támadó/megtámadott & $\mathrm{ApSu}$ & $\mathrm{FoFu}$ & $\mathrm{LaEm}$ & $\mathrm{FoGa}$ & $\mathrm{Te}$ & $\mathrm{MySa}$ & $\mathrm{CaLi}$ & $\mathrm{FoPr}$ & Össz.: \\
\hline Aphaenogaster subterranea & $0 / 1$ & $14 / 4$ & $0 / 1$ & - & $1 / 0$ & $0 / 1$ & $0 / 2$ & $0 / 1$ & $\mathbf{1 5 / 1 0}$ \\
Formica fusca & $0 / 4$ & $0 / 1$ & - & - & - & - & - & - & $0 / 5$ \\
Lasius emarginatus & $0 / 1$ & $8 / 0$ & - & $1 / 0$ & - & - & - & - & $9 / 1$ \\
Formica gagates & - & - & - & - & - & - & - & - & - \\
Temnothorax spp. & - & - & - & - & $0 / 1$ & - & - & - & $0 / 1$ \\
Myrmica sabuleti & $0 / 1$ & - & - & - & - & - & - & - & $0 / 1$ \\
Camponotus ligniperdus & $0 / 2$ & - & - & - & - & - & - & - & $0 / 2$ \\
Formica pratensis & $0 / 1$ & $1 / 0$ & - & - & - & - & - & - & $1 / 1$ \\
\hline Összesen: & $0 / 10$ & $\mathbf{2 3 / 5}$ & $0 / 1$ & $1 / 0$ & $1 / 1$ & $0 / 1$ & $0 / 2$ & $0 / 1$ & $25 / 21$ \\
\hline
\end{tabular}

37. táblázat. A csalétkekről való kizárások száma a litéri fenyvesben. Az egyes sorokban a kizáró, az oszlopokban pedig a kizárt fajok láthatók. Az egyes cellákban szereplő számok azon egyperces megfigyelések számát jelölik, amelyeknél kizárás (nem agresszív kizárás/agresszív kizárás) volt regisztrálható.

\begin{tabular}{lcccccccc|c}
\hline kizáró/kizárt & $\mathrm{ApSu}$ & $\mathrm{FoFu}$ & $\mathrm{LaEm}$ & $\mathrm{FoGa}$ & $\mathrm{Te}$ & $\mathrm{MySa}$ & $\mathrm{CaLi}$ & $\mathrm{CaFa}$ & Össz.: \\
\hline Aphaenogaster subterranea & - & $26 / 54$ & - & - & $3 / 2$ & $0 / 1$ & - & - & $\mathbf{2 9 / 5 7}$ \\
Formica fusca & $5 / 0$ & - & - & - & $4 / 1$ & $0 / 1$ & - & - & $9 / 2$ \\
Lasius emarginatus & - & $5 / 13$ & - & $0 / 1$ & - & - & - & $1 / 0$ & $6 / 14$ \\
Formica gagates & $0 / 1$ & $0 / 2$ & - & - & - & $0 / 1$ & - & - & $0 / 4$ \\
Temnothorax spp. & - & - & - & - & $0 / 1$ & - & - & - & $0 / 1$ \\
Myrmica sabuleti & - & $5 / 0$ & - & $0 / 1$ & $0 / 3$ & - & - & - & $5 / 4$ \\
Camponotus ligniperdus & $3 / 1$ & $7 / 6$ & - & $0 / 1$ & $0 / 1$ & - & - & - & $10 / 9$ \\
Camponotus fallax & - & - & - & - & - & - & - & - & - \\
\hline Összesen: & $8 / 2$ & $\mathbf{4 3 / 7 5}$ & - & $0 / 3$ & $7 / 8$ & $0 / 3$ & - & $1 / 0$ & $59 / 91$ \\
\hline
\end{tabular}

Az egyes fajok között a ,győzelemmel” végző interakcióik relatív arányában szignifikáns különbség mutatkozott (Khi-négyzet próba, $\chi^{2}=204,98 ; \quad \mathrm{df}=5 ; \quad \mathrm{p}<0,001$ ); arányaiban a legtöbb kizárás (legnagyobb dominancia index) a C. ligniperdus, L. emarginatus, A. subterranea, ill. a M. sabuleti, míg a legkevesebb (legkisebb dominancia 
index) a $F$. fusca és a Temnothorax-fajok esetében volt jellemző (38. táblázat). A dominancia mértéke, ellentétben az előző élőhellyel, az egyes fajokra jellemző többi fontosabb változó egyikével sem korrelált szignifikánsan (Függelék 12-13. táblázat).

Az inkonzisztenciák hiánya ellenére a gyakoribb fajok a füredi tölgyeshez hasonlóan itt sem szerveződtek szignifikánsan lineáris dominancia-hierarchiába $\left(h^{\prime}=0,50 ; p=0,22\right)$ (Függelék 15. táblázat).

38. táblázat. A dominancia rangsorrendje a gyakoribb ( $\geq 10$ kizárással végződő interakcióban résztvevő) fajokra a litéri fenyvesben. A Khi-négyzet próba alapján egymástól szignifikánsan különbözö $(\mathrm{p}<0,05)$ fajokat különbözö betüjelek jelölik. DI: dominancia index; n: megfigyelések száma.

\begin{tabular}{lccc}
\hline Fajok & $\mathrm{DI}^{\dagger}$ & $\mathrm{n}$ & $\chi^{2}$-próba \\
Camponotus ligniperdus & 1,00 & 19 & $\mathrm{~A}$ \\
Lasius emarginatus & 1,00 & 20 & $\mathrm{~A}$ \\
Aphaenogaster subterranea & 0,90 & 96 & $\mathrm{~A}$ \\
Myrmica sabuleti & 0,75 & 12 & $\mathrm{~A}$ \\
Formica fusca & 0,09 & 129 & $\mathrm{~B}$ \\
Temnothorax spp. & 0,06 & 16 & $\mathrm{C}$ \\
\hline 'Azon interakciók gyakorisága, & melyekből az & illetö faj \\
„győztesként” került ki (tkp. a kizárások és az összes \\
kizárással/meneküléssel járó interakció hányadosa).
\end{tabular}

\subsection{Prenolepis nitens téli aktivitása}

A téli aktivitásvizsgálat során a $P$. nitens volt az egyetlen hangyafaj, amelynek dolgozói a csalétkeket látogatták, ill. a kvadrátokban detektálhatóak voltak, ugyanakkor rajtuk kívül más gerinctelenek, föként bársonyatkák (Trombididae) és farkaspókok (Lycosidae) is rendszeresen megjelentek a felvételezések ideje alatt.

Bár a $P$. nitens egy kivételével mindegyik vizsgálati napon aktív volt, aktivitása összességében meglehetősen széles skálán mozgott (21. ábra, 39. táblázat). Mind az elfoglalt csalétkek relatív aránya, mind pedig a kvadrátokban regisztrált dolgozók átlagegyedszáma pozitívan korrelált a talajhőmérséklettel (Pearson-féle korrelációs teszt, csalétkek: $r=0,91$; $\mathrm{p}<0,01$; kvadrátok: $\mathrm{r}=0,81 ; \mathrm{p}<0,05)$, ugyanakkor az előbbiek és a talajfelszínén mért léghőmérséklet között nem volt kimutatható szignifikáns összefüggés (csalétkek: $r=0,37$; $\mathrm{p}=0,42 ;$ kvadrátok: $\mathrm{r}=0,62 ; \mathrm{p}=0,14)$. 


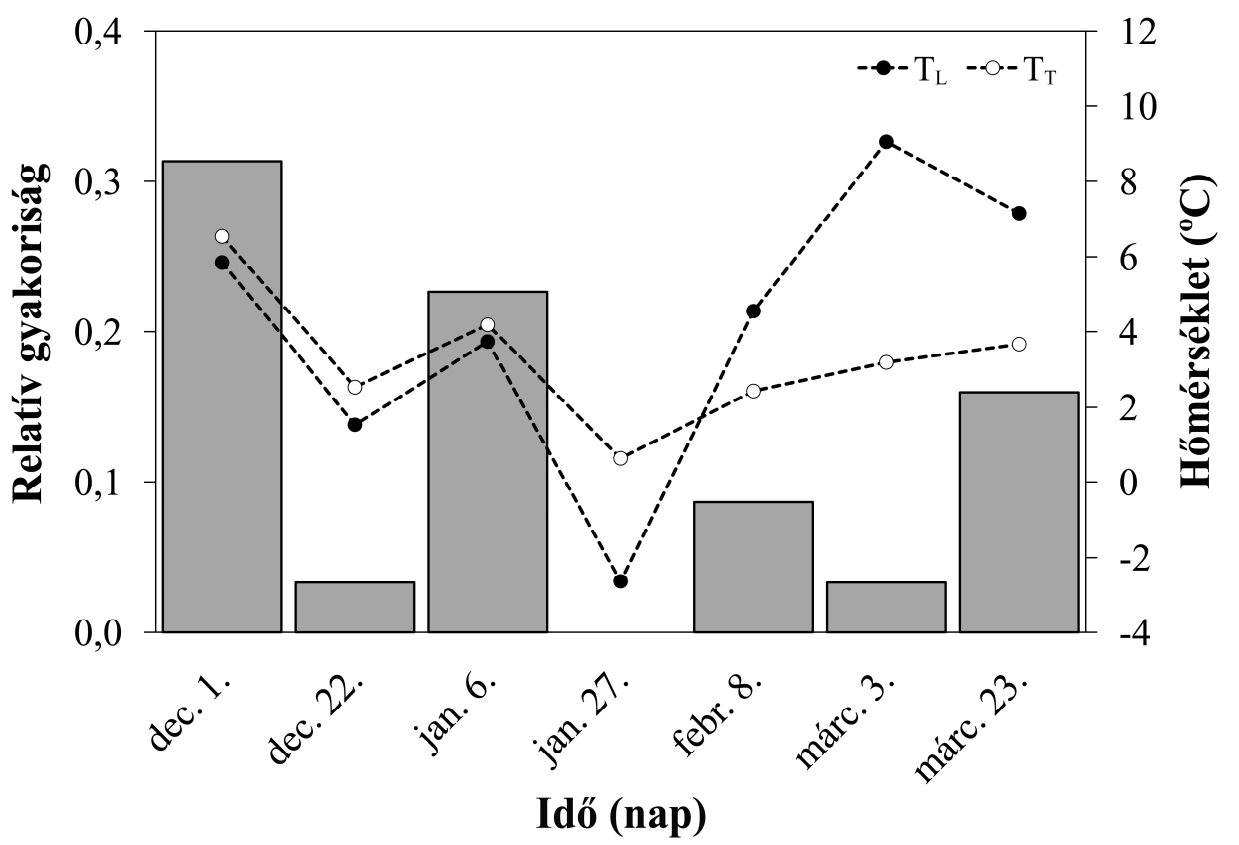

21. ábra. A Prenolepis nitens csalétkeken regisztrált téli aktivitása a füredi tölgyesben. A relatív gyakoriságok az ötórás megfigyelések során elfoglalt csalétkek számának arányát jelentik a térben és időben maximálisan elfoglalható összcsalétekszámhoz $(150=30$ csalétek $\times 5$ felvétel $)$ viszonyítva. $\mathrm{T}_{\mathrm{L}}$ : átlag napi léghőmérséklet; $\mathrm{T}_{\mathrm{T}}$ : átlag napi talajhőmérséklet.

39. táblázat. A Prenolepis nitens kiskvadrátokban megfigyelt téli aktivitása a füredi tölgyesben. $\mathrm{T}_{\mathrm{L}}$ : átlag napi léghőmérséklet; $\mathrm{T}_{\mathrm{T}}$ : átlag napi talajhőmérséklet.

\begin{tabular}{lcccc}
\hline & $\begin{array}{c}\text { összes regisztrált } \\
\text { egyed }\end{array}$ & $\begin{array}{c}\text { átlagegyedszám } \\
\text { 土szórás }\end{array}$ & $\mathrm{T}_{\mathrm{L}}\left({ }^{\circ} \mathrm{C}\right)$ & $\mathrm{T}_{\mathrm{T}}\left({ }^{\circ} \mathrm{C}\right)$ \\
dec. 1. & 32 & $2,13 \pm 1,73$ & 5,85 & 6,53 \\
dec. 22. & 1 & $0,07 \pm 0,26$ & 1,53 & 2,53 \\
jan. 6. & 15 & $1,00 \pm 1,07$ & 3,73 & 4,18 \\
jan. 27. & 0 & $0,00 \pm 0,00$ & $-2,63$ & 0,63 \\
febr. 8. & 21 & $1,40 \pm 1,55$ & 4,55 & 2,43 \\
márc. 3. & 10 & $0,67 \pm 0,82$ & 9,05 & 3,18 \\
márc. 23. & 23 & $1,53 \pm 2,03$ & 7,15 & 3,67 \\
\hline
\end{tabular}

A legalacsonyabb talajfelszíni hőmérséklet, ill. talajhőmérséklet, amelyen a dolgozók aktívak voltak $1,3{ }^{\circ} \mathrm{C}$, ill. $2,5^{\circ} \mathrm{C}$ volt a csalétkes, és $0,9{ }^{\circ} \mathrm{C}$, ill. $2,5^{\circ} \mathrm{C}$ a kiskvadrátos felvételezések során.

Eltérően a tavasz-nyár-őszi csalétkezések során megfigyeltektől, a dolgozók csaknem kizárólag a talajfelszínen elhelyezett csalétkeket látogatták, a fákon lévőkön mindössze két esetben, a legelső vizsgálati napon fordultak elő.

A csalétkeket látogató dolgozók táplálékpreferenciájában szignifikáns különbség volt kimutatható, a mézre mint szénhidrátban gazdag táplálékforrásra az egyes kolóniák tagjai átlagosan jóval több egyedet rekrutáltak (Wilcoxon-féle előjeles rangpróba, $z=3,45 ; p<0,001$; n=128) (22. ábra). 


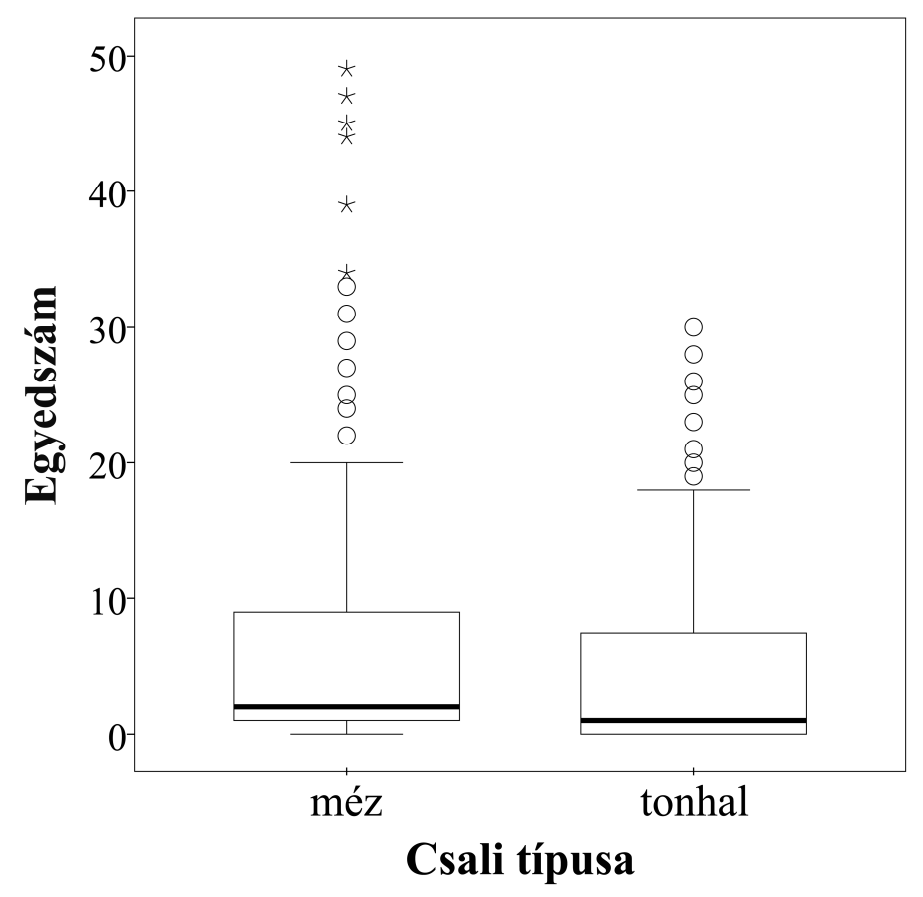

22. ábra. A Prenolepis nitens táplálékpreferenciája a téli csalétkezés során a füredi tölgyesben a hat napra összesítve. A boxok az interkvartilis tartományt, a boxokban lévő vízszintes vonalak a mediánokat, a talpak az interkvartilis tartomány 1,5-szereseit, az üres körök és csillagok pedig a kiugró-, ill. az extrém kiugró értékeket jelölik.

A kiskvadrátos felvételezések során összesen hét esetben sikerült a kvadrátokban regisztrált dolgozók által szállított zsákmányállatokat begyüjteni, amelyek közül hat ugróvillás (Collembola), egy pedig televényféreg (Annelida: Enchytraeidae) volt.

\subsection{Aphaenogaster subterranea eszközhasználata}

A vizsgálatok során az A. subterraneán kívül más hangyafajok (pl. Temnothorax spp., Formica spp., Camponotus spp.) csak elvétve látogatták a csalétkeket, és csupán néhány alkalommal fordultak elő együtt a vizsgált fajjal. Összességében viszonylag alacsony aktivitás jellemezte magát az A. subterraneát is, amelynek dolgozói az egyes felvételezési napokon mindössze a csalétkek harmadát-negyedét foglalták el.

Az egyes kolóniák tagjai a mézre mint táplálékforrásra szignifikánsan több dolgozót rekrutáltak, mint a petrolátumra (Wilcoxon-féle elöjeles rangpróba, $\mathrm{z}=9,55 ; \mathrm{p}<0,001 ; \mathrm{n}=123$ ) (23. ábra). 


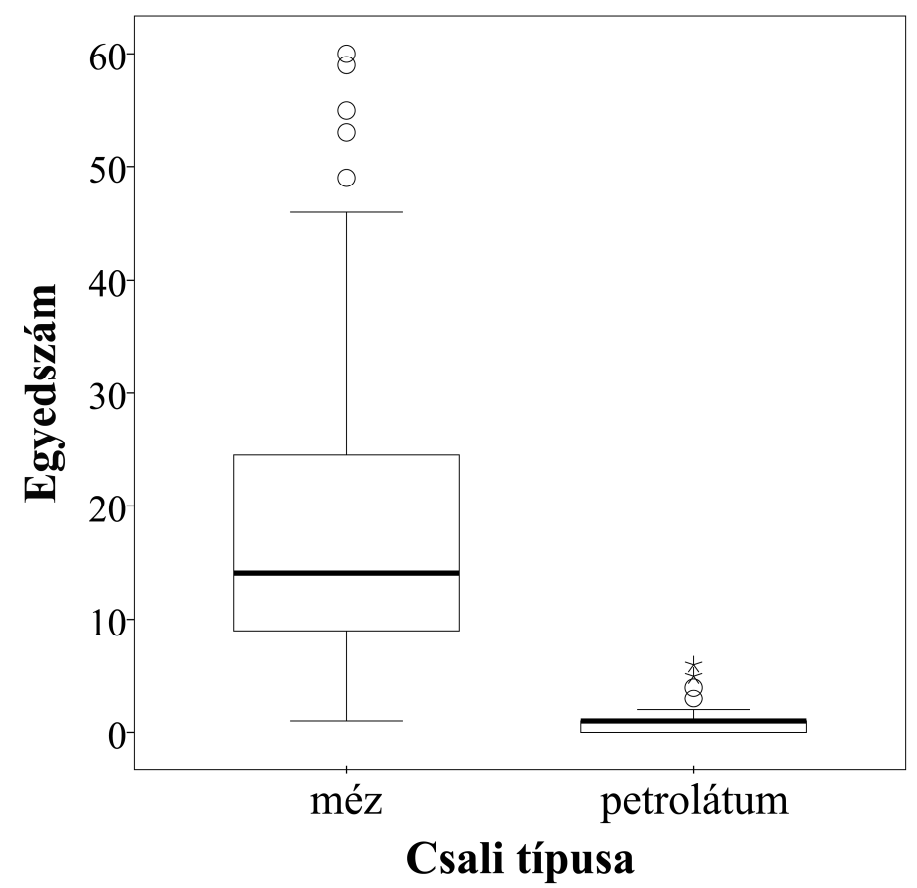

23. ábra. Az Aphaenogaster subterranea csalipreferenciája. A boxok az interkvartilis tartományt, a boxokban lévő vízszintes vonalak a mediánokat, a talpak az interkvartilis tartomány 1,5-szereseit, az üres körök és csillagok pedig a kiugró-, ill. az extrém kiugró értékeket jelölik.

Az A. subterranea táplálékforráson mutatott eszközhasználatát alapvetően három, időben egymástól elkülönülő fázisra lehetett felosztani, amelyet rendszerint más-más dolgozók láttak el: (1) a ráhordási fázis során a dolgozók egyesével, többször fordulva hordták rá a kiválasztott „eszközöket” a folyékony táplálékra, egészen addig, míg annak teljes felszínét be nem fedték velük; (2) a pozícionálási fázis során a dolgozók aszerint módosították a táplálékra hordott „eszközök” pozícióját, hogy azok minél jobban átitatódjanak, ill. minél több táplálék tapadjon meg a felszínükön; míg (3) az elszállítási fázis során a táplálékkal már kellőképpen átitatottnak, ill. bevontnak ítélt „eszközöket” a dolgozók a csalilapról a fészek irányába szállították el.

Egy esetben sikerült a fenti sémától eltérést megfigyelni (és egyúttal videofelvételen rögzíteni), amikor is egy látszólag ráhordást végző dolgozó nem helyezte rá az általa hordozott „eszközt” a táplálékra, hanem ehelyett a rágói között tartva kezdte el azt a mézbe mártogatni, majd az ily módon kezelt, táplálékkal átitatott „,eszközt” rögtön el is szállította.

Az „eszközökkel” foglalatoskodó dolgozók egyedszáma a csalin táplálkozó és különösebb tevékenység nélkül jelenlévő dolgozókénál szignifikánsan kisebbnek bizonyult (Wilcoxon-féle előjeles rangpróba, $z=9,41 ; \mathrm{p}<0,001 ; n=123$ ) (24. ábra), ugyanakkor a kettő között viszonylag erős pozitív korreláció volt kimutatható (Spearman-féle korrelációs teszt, 
$\mathrm{r}=0,54 ; \mathrm{p}<0,001 ; \mathrm{n}=123$ ), azaz minél több dolgozó jelent meg a csalétkeken, rendszerint annál több mutatott valamely eszközhasználattal kapcsolatos viselkedési formát.

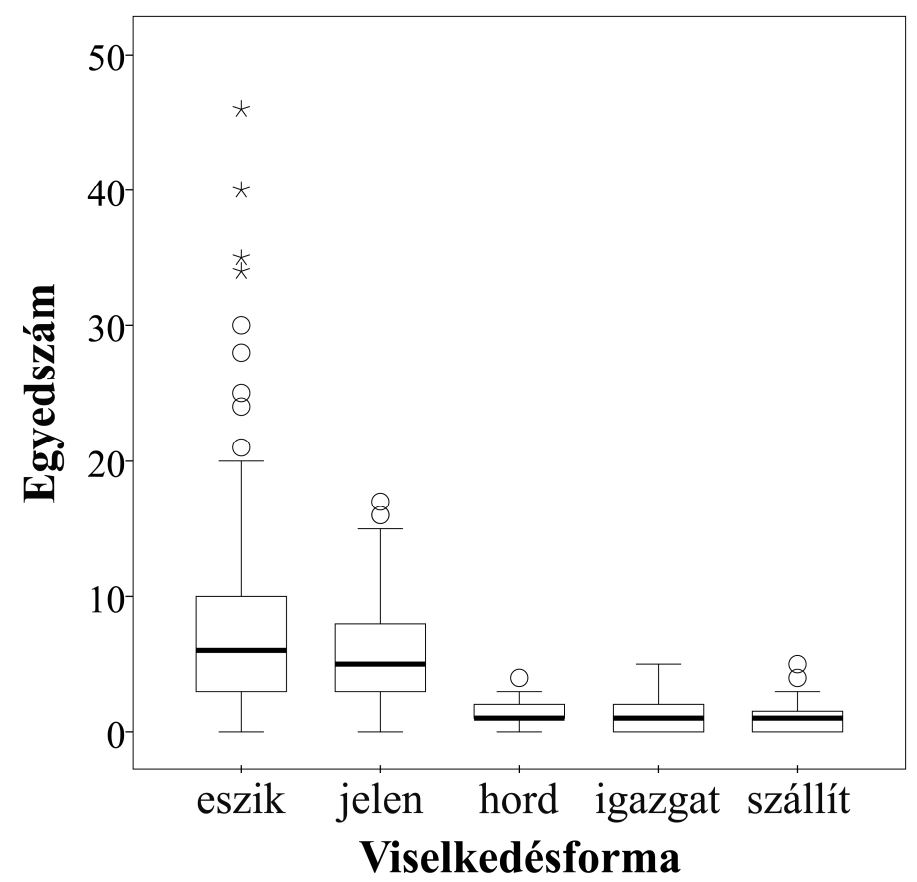

24. ábra. Az Aphaenogaster subterranea csalétkeken mutatott egyedi viselkedésformái és ezek egyedszámbeli megoszlása. A boxok az interkvartilis tartományt, a boxokban lévő vízszintes vonalak a mediánokat, a talpak az interkvartilis tartomány 1,5-szereseit, az üres körök és csillagok pedig a kiugró-, ill. az extrém kiugró értékeket jelölik. /"eszik"/: a csalin táplálkozik; /"jelen"/: különösebb tevékenység nélkül tartózkodik a csalétken; /"hord"/: „eszközt” hord rá a csalira; /"igazgat"/: egy már előzőleg a csalira ráhordott „eszköz” helyzetét módosítja; /"szállít"/: egy már előzőleg a csalira ráhordott „eszközt” szállít el a csalétekről a fészek irányába.

Noha az egyperces megfigyelések során egyszerre négynél több ráhordást végző dolgozót egyik kolónia esetében sem sikerült regisztrálni, ez idő alatt ezen dolgozók rendszerint többször, átlagosan 1,21-szer $( \pm 0,41 ; n=172)$ is fordultak.

Az aktívabb, az egyes csalétkekre nagyobb számú (>40) dolgozót rekrutáló kolóniák esetében a csalin táplálkozó és különösebb tevékenység nélkül jelenlévő dolgozók egyedszáma egy kezdeti növekedési, majd telítődési szakasz után tipikusan lecsengett egy-két órán belül, míg az „eszközökkel” foglalatoskodó dolgozók egyedszáma végig viszonylag konstans maradt (25. ábra). 


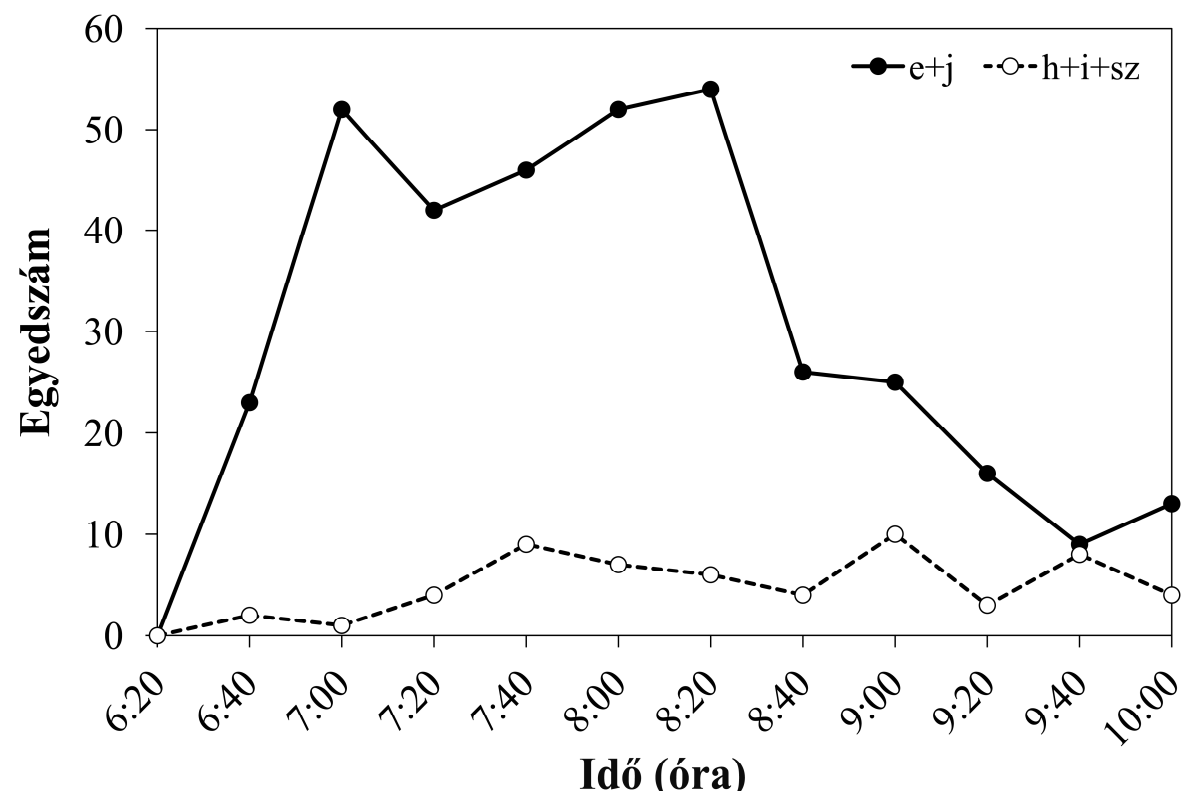

25. ábra. A csalétkeken mutatott viselkedésformák időbeli dinamikája az aktívabbnak bizonyuló Aphaenogaster subterranea kolóniák egyike esetében. /e+j/: a csalin táplálkozó és különösebb tevékenység nélkül jelenlévő dolgozók ("eszik"+"jelen"); /h+i+sz/: az „eszközökkel” foglalatoskodó dolgozók ("hord"+"igazgat"+"szállít").

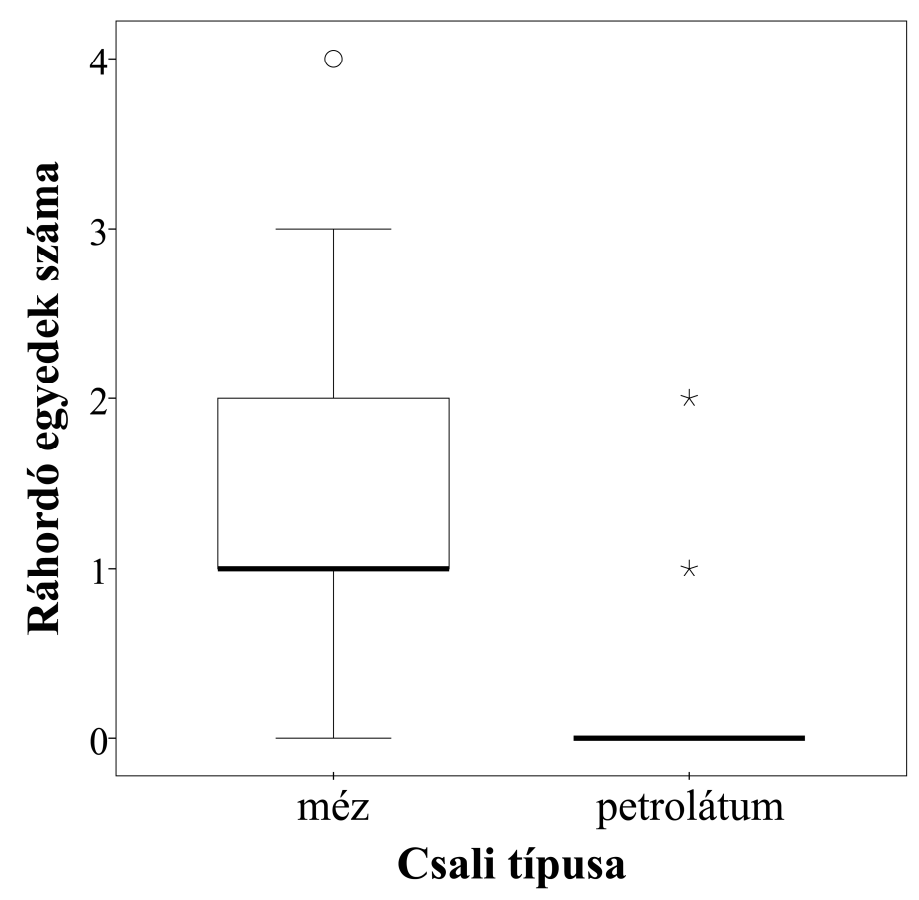

26. ábra. Az Aphaenogaster subterranea ráhordást végző egyedeinek számbeli megoszlása a kétféle csalitípusnál. A boxok az interkvartilis tartományt, a boxokban lévő vízszintes vonalak a mediánokat, a talpak az interkvartilis tartomány 1,5-szereseit, az üres körök és csillagok pedig a kiugró-, ill. az extrém kiugró értékeket jelölik.

Bár a csalétkeket látogató dolgozók többsége egyszerüen ignorálta a petrolátumot, néhány egyedből a rövid antennázást követően menekülő vagy éppen támadó reakciót váltott ki. Emellett a csalétkek 60\%-án a dolgozók a felvételezés ideje alatt a petrolátumra is 
végeztek ráhordást, azonban a mézhez képest jóval kisebb intenzitással (Wilcoxon-féle elöjeles rangpróba, $\mathrm{z}=8,41 ; \mathrm{p}<0,001 ; \mathrm{n}=123$ ) (26. ábra).

Az A. subterranea dolgozók „,eszközként” talajszemcséket és különböző, könnyebben mozdítható növényi törmelékanyagokat (pl. fenyőtü-, toboz- vagy kéregdarabokat) használtak fel, amelyeket a ráhordást végző dolgozók mindig közvetlenül a csalétkek mellől gyüjtöttek be, gyakran csupán lenyúlva a csalilapok széléről, és úgy emelve fel a kiszemelt „eszközöket” rágóik és elülső pár lábaik segítségével. Az „eszközök” hordását és szállítását a dolgozók jellemzően mindig egyesével végezték, a nagyobb, mézzel átitatott darabok elszállítása azonban néhány esetben kooperáltan, két dolgozó közremüködésével együtt történt.

\subsection{Aphaenogaster subterranea asszociációja recéskabócákkal}

A kvadrátos felvételezések során összesen 9 hangyafaj 148 fészkét sikerült regisztrálni (40. táblázat). A legabundánsabb és leggyakoribb faj az A. subterranea volt, amelynek fészkei az összfészekszámnak több mint a felét tették ki, és amelyek egy kvadrát kivételével mindegyikben detektálhatóak voltak, a többi fajhoz hasonlóan többnyire kövek alatt.

40. táblázat. A hangya-kabóca asszociáció vizsgálata során térlépezett hangyakolóniák relatív abundanciája és gyakorisága, ill. fészkeinek száma a fészkelőhely típusa alapján. A relatív abundancia itt az egyes fajok fészkeinek és az összfészekszámnak a hányadosát, míg a relatív gyakoriság azon kvadrátoknak az összkvadrátszámhoz viszonyított arányát jelenti, amelyben az illető faj fészke elöfordult.

\begin{tabular}{lcccccc}
\hline Fajok & $\begin{array}{c}\text { Relatív } \\
\text { abundancia }\end{array}$ & $\begin{array}{c}\text { Relatív } \\
\text { gyakoriság }\end{array}$ & & \multicolumn{4}{c}{ Fészkelöhely típusa } \\
\cline { 5 - 7 } & & & $\begin{array}{c}\text { Kövek } \\
\text { alatt }\end{array}$ & Talajban & Avarban & $\begin{array}{c}\text { Faágak- } \\
\text { ban }\end{array}$ \\
Aphaenogaster subterranea & $\mathbf{0 , 5 1}$ & $\mathbf{0 , 9 6}$ & 53 & 9 & 9 & 4 \\
Lasius brunneus & 0,05 & 0,20 & 5 & 3 & 0 & 0 \\
L. citrinus & 0,04 & 0,16 & 5 & 1 & 0 & 0 \\
L. emarginatus & 0,07 & 0,24 & 7 & 2 & 3 & 0 \\
Myrmecina graminicola & 0,01 & 0,04 & 1 & 0 & 0 & 0 \\
Ponera coarctata & 0,03 & 0,16 & 4 & 0 & 0 & 0 \\
Prenolepis nitens & $\mathbf{0 , 2 7}$ & $\mathbf{0 , 7 2}$ & 38 & 1 & 1 & 0 \\
Temnothorax crassispinus & 0,01 & 0,04 & 0 & 0 & 0 & 1 \\
T. unifasciatus & 0,01 & 0,04 & 0 & 0 & 0 & 1 \\
\hline
\end{tabular}

Hangyafészkeken belül összesen 110 kabócanimfát találtam, amelyek 96\%-a (106 egyed) az A. subterranea 31 (41\%) fészkéböl került elö. Más hangyafajok fészkeiben mindössze három esetben fordultak elő nimfák, két esetben egy-egy $P$. nitens fészekben, egy esetben pedig egy L. brunneus kolónia ún. szatellita-fészkében. 
A kabócanimfák átlagos száma az A. subterranea fészkeiben $3,42( \pm 2,84)$ volt, a legnagyobb regisztrált nimfacsoport 12 egyedből állt. A nimfákkal rendelkező és nimfa nélküli fészkek aránya az egyes mintavételi időszakokban 1:0,9 és 1:4 között változott (41. táblázat). A 31, nimfákkal rendelkező A. subterranea fészken túl további háromban találtam elpusztult nimfákat, ill. két további fészek tartalmazott csupán nimfák által hátrahagyott viaszszálakat.

41. táblázat. A Reptalus panzeri nimfáinak jelenlét/hiánya, összegyedszáma és becsült mérete az Aphaenogaster subterranea fészkeiben az öt mintavételi nap során.

\begin{tabular}{lccccc}
\hline Mintavételi nap & \multicolumn{2}{c}{ Fészkek száma } & \multicolumn{3}{c}{ A fészkekben talált nimfák } \\
& \multicolumn{5}{c}{ száma és becsült mérete } \\
\cline { 2 - 6 } & nimfákkal & $\begin{array}{c}\text { nimfák } \\
\text { nélkül }\end{array}$ & kicsi & közepes & nagy \\
máj. 30. & 7 & 9 & - & 7 & 21 \\
jún. 10. & 4 & 6 & 1 & - & 27 \\
júl. 19. & 3 & 12 & 3 & 1 & - \\
aug. 1. & 10 & 11 & 27 & 5 & - \\
szept. 12. & 7 & 6 & 2 & 12 & - \\
\hline Összesen: & 31 & 44 & 33 & 25 & 48 \\
\hline
\end{tabular}

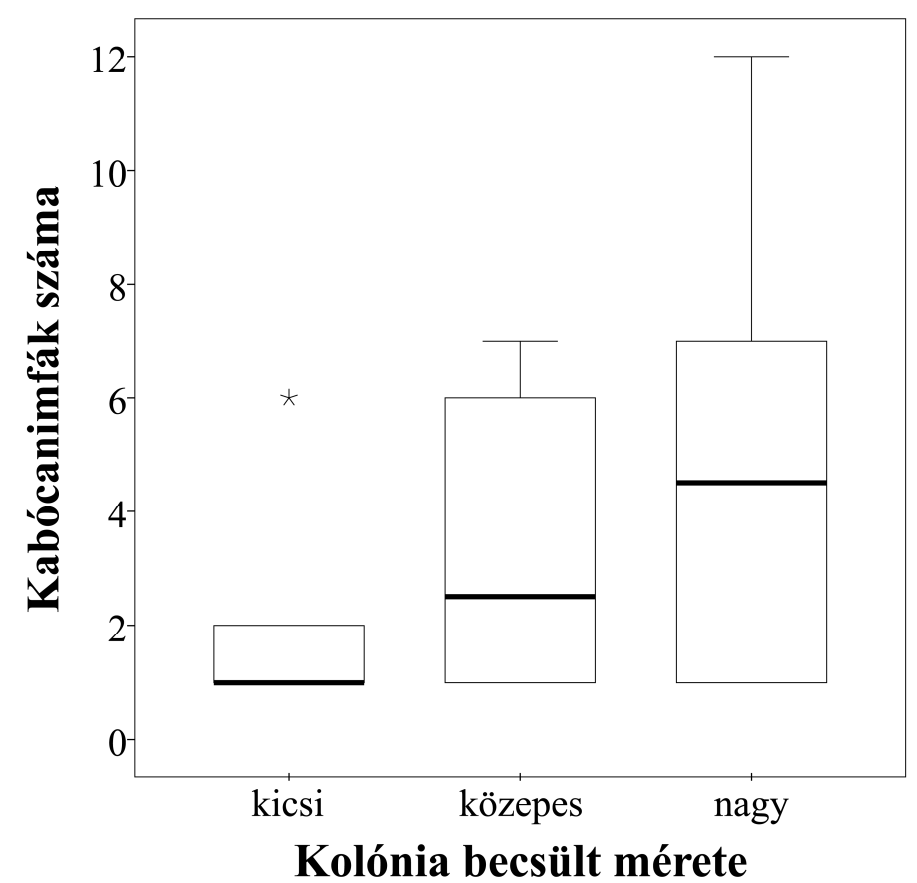

27. ábra. A Reptalus panzeri nimfák egyedszámainak összehasonlítása a különböző méretű Aphaenogaster subterranea kolóniák fészkeiben. A boxok az interkvartilis tartományt, a boxokban lévő vízszintes vonalak a mediánokat, a talpak az interkvartilis tartomány 1,5-szereseit, a csillagok pedig az extrém kiugró értékeket jelölik. 
A fészkeikben talált nimfák egyedszáma tekintetében a különböző nagyságú A. subterranea kolóniák között nem volt kimutatható szignifikáns különbség (Kruskal-Wallis próba, $\chi^{2}=3,49 ; \mathrm{df}=2 ; \mathrm{p}=0,18 ; \mathrm{n}_{\text {kicsi }}=10 ; \mathrm{n}_{\text {közepes }}=12 ; \mathrm{n}_{\text {nagy }}=9$ ) (27. ábra).

Nyár elején az A. subterranea fészkeiben talált kabócanimfák többnyire késői fejlődési stádiumú, nagyobb méretü egyedekből álltak, míg ezzel szemben a nyár végi időszakban a korai fejlődési stádiumú, kisebb méretü nimfák domináltak (41. táblázat).

Hangyafészken kívül mindössze hat esetben találtam kabócanimfákat, amelyek többnyire egyedül, esetleg párosával fordultak elő, a közelükben rendszerint néhány A. subterranea dolgozóval. Hasonlóképpen A. subterranea dolgozókkal együtt találtam meg azt a két nimfát is, amelyek az egyik $P$. nitens kolónia fészkének felszínhez közeli részén tartózkodtak.

Az A. subterranea fészkein belül a kabócanimfák vagy szorosan egymás mellett, gyakran viaszcsomóba burkolva voltak megtalálhatóak, vagy pedig a fészek különböző részein szétszórtan helyezkedtek el a hangyadolgozókkal és ivadékokkal együtt. A kövek alatt fészkelő kolóniákkal asszociáló nimfák rendszeresen tartózkodtak a fészkeket borító kövek alján (28-29. ábrák), ugyanakkor a vártakkal ellentétben a fészekbe nyúló gyökereken mindössze egy-két alkalommal sikerült csak nimfákat megfigyelni. A legnagyobb, 12 egyedből álló nimfacsoport esetében a viaszcsomóba burkolt nimfákat meglepő módon a talaj felszíne felett az avarban, közvetlenül egy földre hullott, korhadt faág alatt találtam meg, amelyben egy nagyobb A. subterranea kolónia fészkelt.

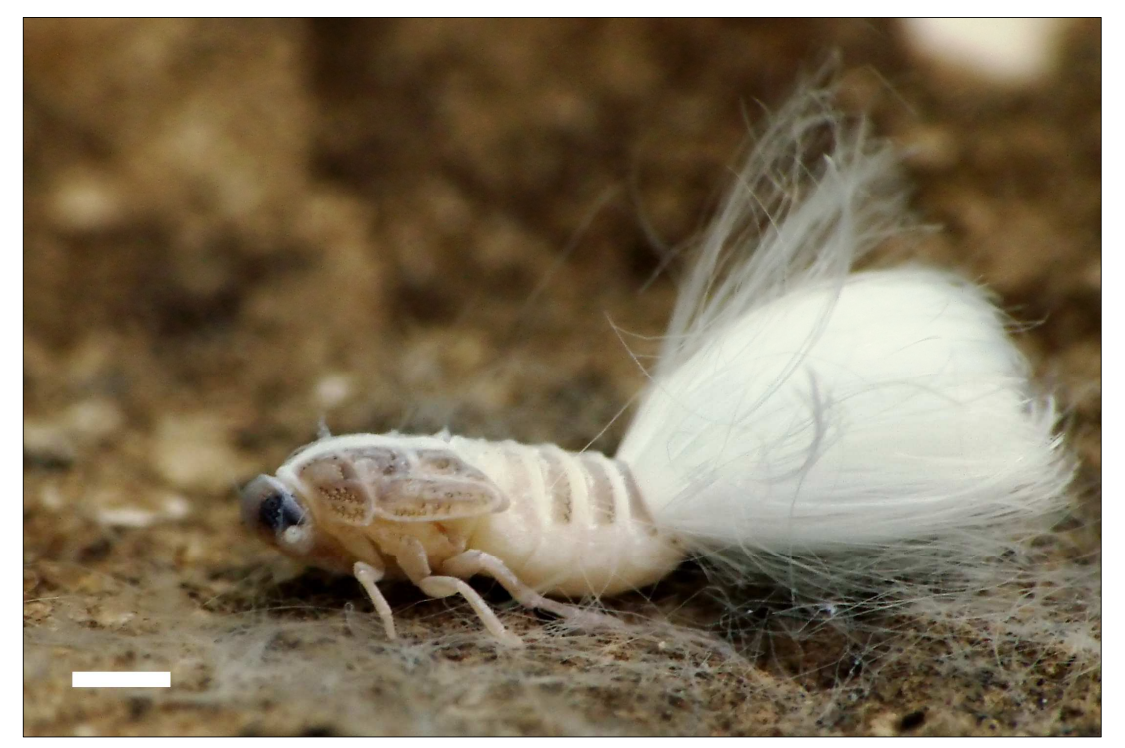

28. ábra. A Reptalus panzeri egy késői fejlődési stádiumú nimfája egy Aphaenogaster subterranea fészket borító felfordított kő alján (füredi tölgyes). Mérce = kb. $1 \mathrm{~mm}$. 


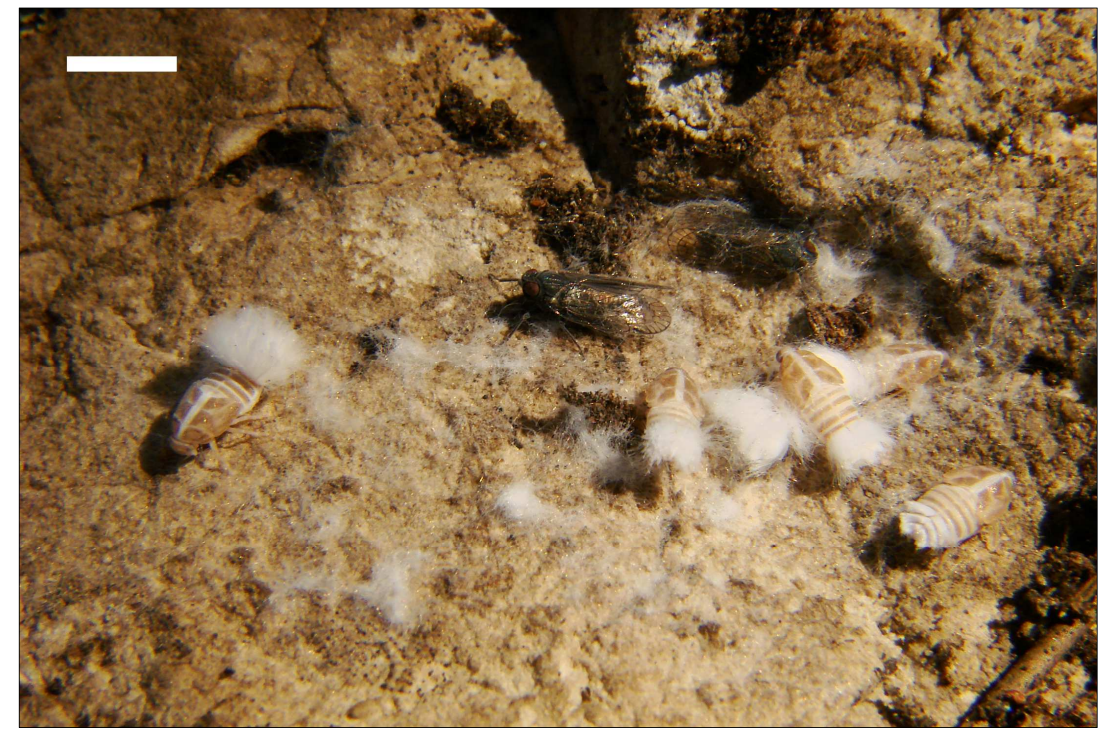

29. ábra. Reptalus panzeri nimfák és imágók egy Aphaenogaster subterranea fészket borító felfordított kő alján (litéri fenyves). Mérce = kb. 4 mm.

A nimfákkal asszociáló A. subterranea kolóniák mintegy 65\%-a virágos kőrisek (F. ornus) gyökerei között, vagy legalábbis virágos körisek közvetlen közelében fészkelt. A fennmaradó esetekben a gazdanövény pontos kiléte nem volt teljesen egyértelmüen megállapítható, ugyanakkor valószínű, hogy a molyhos tölgy ( $Q$. pubescens), a húsos som (Cornus mas) és a mezei kőris (Acer campestre) szintén tápnövényül szolgálhat a $R$. panzeri nimfái számára.

Kifejlett kabócákat a vizsgált időszakban három esetben találtam az A. subterranea fészkeiben június vége és július eleje között, függetlenül a fészektérképezésektől. Kettő ezek közül még frissen vedlett, gyengén pigmentált egyed volt, míg a harmadik már rendes színezetü, kirepülésre kész imágó.

A viselkedésbeli interakciók vizsgálata során nem volt megfigyelhető direkt fizikai kontaktus az A. subterranea dolgozók és a kabócanimfák között. Noha a hangyák nem támadták meg a nimfákat, és a nimfák sem próbáltak menekülni (pl. elugrással) a hangyák elöl, lényegében mindkét fél kölcsönösen ignorálta egymás jelenlétét. Egyetlen eset volt csupán, mikor a nimfák egyike egy A. subterranea dolgozó jelenlétében megemelte a potrohát és egy csepp mézharmatot bocsátott ki, azonban a kérdéses dolgozó erre sem adott semmilyen érdemi reakciót. 


\section{Diszkusszió}

5.1. Fészkek denzitásának és diszpergáltságának tér-idő mintázata

A denzitás, ill. a diszpergáltság a populáció-tér viszonyának két kitüntetett karakterisztikája, amelyek közül elöbbi mint mennyiségi jellemző a hangyafészkek adott területegységre vonatkoztatott sürüségét, míg utóbbi mint minőségi jellemző a fészkek térbeli eloszlását fejez ki, és ebben a tekintetben fontos információkkal szolgálhat az olyan mechanizmusok jelentőségéről, mint pl. a populáción belüli vagy a populációk közötti kompetíció (Gallé 2013). Számos eddigi vizsgálat alapján a talajszinten lakó hangyafajok fészkeit leggyakrabban szegregált (egyenletes) diszpergáltság jellemzi, amelynek hátterében a legelfogadottabb magyarázat szerint a kolóniák közötti kompetíció áll (pl. Gallé 1975; Bernstein és Gobbel 1979; Harrison és Gentry 1981; Levings és Traniello 1981; Levings és Franks 1982; Ryti és Case 1984, 1986; Cushman és mtsai. 1988; Schooley és Wiens 2003; Vasconcellos és mtsai. 2004). A különböző konceptuális és szimulációs modellek szerint (pl. Levings és Traniello 1981; Ryti és Case 1992) az erős intra- és/vagy interspecifikus kompetíció ugyanakkor nem csupán a fészkek egyenletes términtázatát, de a diszpergáltság denzitástól való függését is eredményezi, azaz a kolóniák denzitásának növekedésével a fészkek térbeli eloszlásának egyenletessége is nő, amelyet több empirikus tanulmány is alátámaszt (pl. Waloff és Blackith 1962; Gallé 1975, 1980; Cushman és mtsai. 1988; Ryti 1991). Annak eldöntése, hogy egy adott közösségben a populáción belüli vagy a populációk közötti interakciók a jelentősebbek, gyakran a legközelebbi konspecifikus és heterospecifikus fészekszomszéd távolságok összehasonlítása alapján történik (Ryti és Case 1984; Soares és Schoereder 2001). Abban az esetben ugyanis, ha a populáción belüli kompetíció intenzívebb, a fészkek legközelebbi konspecifikus szomszéd távolságai várhatóan meg fogják haladni a legközelebbi heterospecifikus szomszéd távolságokat, míg ellenkező esetben éppen ennek a fordítottjára kell számítanunk.

Jelen vizsgálatok megerősíteni látszanak korábbi eredményeimet (Lőrinczi 2011), miszerint a kompetíció szerepe a két vizsgálati élőhely egyikén sem tünik meghatározónak a fészkek términtázatának kialakításában, hasonlóan néhány más talaj- és avarlakó hangyaközösséghez (pl. Herbers 1989; Soares és Schoereder 2001). Mindezt az alábbiak támasztják alá: (1) nem csupán az egyes, abundánsabb fajok fészkei mutattak az esetek jelentős többségében random diszpergáltságot, de az egyes kvadrátokban regisztrált összes fészek términtázata is többnyire véletlenszerünek bizonyult; (2) egyetlen esetet leszámítva a 
fészkek denzitása és diszpergáltsága között nem volt kimutatható szignifikáns pozitív összefüggés; (3) a fészkek térbeli eloszlásának egyenletessége egyik élőhelyen sem növekedett az évad során, sőt, a fészektérmintázat vagy alapvetően nem is változott jelentősen (litéri fenyves), vagy szegregáltból ment át véletlenszerübe (füredi tölgyes), azaz pont fordítva, mint ahogyan azt erős kompetíció és a kolóniák denzitásfüggő mortalitása esetén várhatnánk.

Különösképp a populációk közötti kompetíció kevésbé kitüntetett szerepét látszik igazolni az, hogy interspecifikusan többnyire a fészkek erőteljes aggregációja volt jellemzö, valamint, hogy a legközelebbi heterospecifikus szomszéd távolságok rendre szignifikánsan kisebbnek bizonyultak a legközelebbi konspecifikus szomszéd távolságoknál, noha abban az esetben, ha az egyes fajok kolóniái kevésbé tolerálnák a másik faj fészkeinek közelségét, az ettől eltérő eredményhez kellett volna, hogy vezessen. Hasonló interspecifikus aggregációt, vagy legalábbis a heterospecifikus szomszédokhoz való közelebbi fészkelést számos korábbi vizsgálatban leírtak már (Harkness és Isham 1983; Ryti és Case 1984, 1986; FernándezEscudero és Tinaut 1999; Sanders és Gordon 2000; Cole és mtsai. 2001). Ennek oka lehet, ha az egyes fajok a konspecifikus fészekszomszédjaiktól mint fő kompetítoraiktól igyekszenek minél távolabb kerülni (Ryti és Case 1984, 1986), vagy ha a heterospecifikus kolóniák között valamilyen kapcsolat áll fenn, pl. az egyik faj a másik tetemeit fogyasztja (Harkness és Isham 1983; Cole és mtsai. 2001). E tekintetben érdekesnek mondható a litéri fenyves két fajpárja, az A. subterranea-C. ligniperdus, ill. a $P$. coarctata-M. graminicola közötti kétirányú pozitív asszociáció, amely akár egyfajta pleziobiotikus kapcsolatra is utalhat ezen fajok között (Kanizsai és mtsai. 2013), lévén fészkeik több esetben is ugyanazon kö alatt voltak megtalálhatóak, egymástól mindössze néhány cm-es távolságra. A gyakori interspecifikus aggregáció ellenére ugyanakkor mindkét élőhely esetében jellemzőek voltak ún. „tiltott”, negatív interspecifikus asszociációt mutató fajpárok is (pl. A. subterranea-L. emarginatus), amelyeknek kolóniái a jelek szerint kevésbé vagy egyáltalán nem tolerálták egymás térbeli közelségét.

Összességében az, hogy jellemzően a legközelebbi konspecifikus fészekszomszéd távolságok bizonyultak nagyobbnak természetesen utalhatna arra is, hogy a közösségen belül a populáción belüli kompetíció a jelentősebb szervező erő, és ennek megfelelően az egyes fajok kerülni igyekszenek a konspecifikus idegen kolóniák közelségét, ezt azonban, mint arról fentebb szó esett, összességében sem a fészkek intraspecifikus términtázata, sem a denzitásdiszpergáltság kapcsolata nem látszott igazolni. Egyedüli kivételt ez alól talán a füredi tölgyes A. subterranea populációja jelenthet, minthogy ennél (1) intraspecifikusan a fészkek az évad 
elején két alkalommal is szegregált diszpergáltságot mutattak, (2) a legközelebbi heterospecifikus fészekszomszéd távolságok minden évszakban szignifikánsan kisebbnek bizonyultak a legközelebbi konspecifikus fészekszomszéd távolságoknál, valamint (3) a kolóniák között összességében negatív intraspecifikus asszociáció volt kimutatható.

Bár a fészkek diszpergáltságának időbeli változása csupán a füredi tölgyesben mutatott határozott irányú szezonális trendet, a legközelebbi fészekszomszéd távolságok mindkét élőhelyen többnyire jelentős ingadozást mutattak az évad során, amely megerősíti a tér- és időbeli mintázatok együttes vizsgálatának szükségességét (ld. még Herbers 1985, 1989, 2011; Petrov és Gallé 1986; Traniello és Levings 1986; Gallé és mtsai. 1994; Cerdá és mtsai. 2002; Dillier és Wehner 2004). Noha ez az évszakos változás az egyes, abundánsabb fajok esetében viszonylag egyedi módon és mértékben mutatkozott meg, rendszerint a fészekszomszéd távolságok megnövekedését jelentette, amely kétségkívül a fészkek tavasztól őszig való denzitáscsökkenésének tudható be. Ennek oka feltehetőleg egyrészt a kisebb és/vagy fiatalabb kolóniák mortalitásában, másrészt pedig az egyes kolóniáknak a szezon vége felé történő aktivitáscsökkenésében keresendö, amint a talaj mélyebb rétegeibe húzódva megkezdik téli hibernációjukat.

Két faj, a $P$. nitens és a $L$. emarginatus esetében mindazonáltal a fentiektől jelentősen eltérő trend volt megfigyelhető, amely alighanem azzal magyarázható, hogy ezen fajok kolóniái vagy szezonálisan polidómuszosak (a kifejezés tágabb értelmében véve, ld. Debout és mtsai. 2007), azaz az év bizonyos szakában több, különálló fészket elfoglaló alegységre fragmentálódnak, vagy ezen időszakokban a dolgozók több fészekkijáratot is megnyitnak. Mindkét térbeli „konfigurációnak” egyaránt előnye lehet a táplálékkeresési hatékonyság megnövekedése azáltal, hogy ennélfogva az adott kolónia táplálkozási területe jelentősen kiterjed, a keresési idő, ill. a dolgozók által a táplálékforrás és a fészek között megtett távolságok pedig ugyanakkor lecsökkennek (Traniello és Levings 1986; Cerdá és mtsai. 2002; Debout és mtsai. 2007).

A L. emarginatus esetében, amelynek fészekdenzitása a nyár elején érte el maximumát feltehetőleg inkább szezonális polidómiáról lehet szó, lévén a fészektérképezések során gyakran voltak megfigyelhetőek ún. „ideiglenes állomások” vagy szatellita-fészkek ezen faj kolóniáinál. Noha a polidómuszos hangyafajok fészkeit jellemzően aggregált diszpergáltság jellemzi (pl. Higashi és mtsai. 1987; Herbers 1989; Cerdá és mtsai. 2002; Dillier és Wehner 2004), a L. emarginatus fészkeinek términtázata többnyire véletlenszerünek bizonyult, és csupán egyetlen alkalommal, nyár végén mutatott jelentősebb aggregáltságot. A polidómiát látszik igazolni ugyanakkor ezen faj esetében, hogy (1) tavaszról nyár elejére a fészkek 
legközelebbi konspecifikus szomszéd távolságai jelentős mértékben lecsökkentek, (2) a nyár eleji időszakban, amikor a fészkek denzitása a legnagyobb volt, a legközelebbi konspecifikus és heterospecifikus fészekszomszéd távolságok nem különböztek egymástól szignifikánsan, valamint (3) a fészkeket mindkét élőhelyen összességében pozitív intraspecifikus asszociáció jellemezte. Mindezek mellett ráadásul a két élőhelyen végzett korábbi vizsgálataimban a L. emarginatus fészkei több esetben is aggregált diszpergáltságot mutattak, ill. más fajoktól eltérően a fészkeinek a legközelebbi konspecifikus szomszéd távolságai vagy jelentősen kisebbnek bizonyultak a legközelebbi heterospecifikus fészekszomszéd távolságoknál, vagy nem volt közöttük kimutatható szignifikáns különbség (Lörinczi 2011).

A L. emarginatusszal ellentétben a $P$. nitens esetében már kevésbé egyértelmü, hogy az egyes kolóniák több, különálló fészket elfoglaló alegységre való tagolódásáról, esetleg időlegesen fennálló, a táplálékkereső dolgozók számára alkalmi menedékhelyül szolgáló fészekalegységek kialakulásáról van-e szó, vagy csupán arról, hogy tavasszal, ill. nyár végén és ősszel a dolgozók rendre több fészekkijáratot is megnyitnak. Mindenesetre ezzel esetlegesen összefüggésben állhat, hogy éppen ezen időszakokban (de jellemzően tavasszal) miért jellemezte néhány esetben a faj fészkeit (vagy fészekkijáratait) szegregált términtázat. Ehhez hasonlót írtak le ugyanis egyes Lasius-fajok esetében, amelyeknél a fészekkijáratok diszpergáltsága bár összességében aggregáltnak vagy véletlenszerünek bizonyult, ám az egyes kolóniákon belül, a redundáns táplálékkeresést elkerülendő, nagyfokú szegregáltságot mutatott (Traniello és Levings 1986; Gallé és mtsai. 1994). A L. emarginatus esetében az évad közepén, míg a $P$. nitens esetében a szezon elején és végén mutatott expanzió tehát nagy valószínűség szerint szoros összefüggésben állhat ezen fajok táplálkozási aktivitásával, amelyet a csalétkes vizsgálataim mindkét faj esetében csakugyan alátámasztani is látszanak.

Felmerül a kérdés, hogy a két vizsgálati élőhelyen milyen mértékben jelentenek limitáló tényezőt az alkalmas fészkelőhelyek, és ezáltal ezeknek a térbeli eloszlása mennyiben befolyásolja a hangyafészkek diszpergáltságát. Bizonyos élőhelyeken ugyanis, ahol a talaj- és avarlakó hangyaközösségeket nagyrészt üregi fészkelő fajok alkotják, a fészkek jellemzően aggregált diszpergáltságot mutatnak, ugyanis az erre alkalmas helyek (pl. faágak, fagallyak, termések, gubacsok, stb.) száma erősen korlátozó, térbeli eloszlásuk pedig a véletlenszerütől különbözik (Herbers 1989; Soares és Schoereder 2001). Minthogy jelen vizsgálat során a fészkek términtázata többnyire véletlenszerünek bizonyult, elképzelhető, hogy ezeken az élőhelyeken az alkalmas fészkelőhelyek nem jelentenek korlátozó tényezőt, így ezek abundanciája és diszpergáltsága lesz meghatározó a fészektérmintázat kialakításában, hasonlóan, mint azt pl. a Proformica longiseta esetében kimutatták (Fernández-Escudero és 
Tinaut 1999). Ez a felvetés legalábbis a füredi tölgyes esetében helytálló lehet, ahol a fészkek döntő többsége kövek alatt fordult elő, ugyanakkor nem magyarázza a litéri fenyves esetében tapasztaltakat, ahol is a fészkek egy jelenetős hányada különféle faanyagokban (faágakban, fagallyakban) volt fellelhető.

A fészkek véletlenszerü términtázatát, ill. a denzitás és diszpergáltság pozitív kapcsolatának hiányát magyarázhatja ugyanakkor az is, hogy a kolóniák mortalitása nem denzitástól függő, hanem térben random, amely véletlenszerü diszpergáltságot eredményezhet függetlenül attól, hogy a fészkek términtázata eredetileg aggregált, random vagy szegregált volt (Adams és Tschinkel 1995). Érdemes emellett figyelembe venni azt is, hogy a különböző biotikus interakciók mellett számos környezeti tényező, a talaj típusától kezdve a besugárzás mértékén át a vegetáció jellegéig ugyancsak szerepet játszhat a fészektérmintázat kialakításában (pl. Waloff és Blackith 1962; Bernstein és Gobbel 1979; Doncaster 1981; Cushman és mtsai. 1988; Dugas 2001), akár közvetlenül vagy közvetetten, a különböző denzitásfüggő folyamatokon keresztül hatva (Schooley és Wiens 2003).

Egy további magyarázattal szolgálhat a kolóniák szezonális relokációja, amelyet nem csupán sivatagi és trópusi (Harrison és Gentry 1981; Gordon 1992; Cerdá és mtsai. 2002; Gibb és Hochuli 2003; McGlynn és mtsai. 2004), de számos mérsékeltövi faj esetében is dokumentálták már (Smallwood és Culver 1979; Smallwood 1982; Herbers 1985, 1989; Brown 1999; Fernández-Escudero és Tinaut 1999). Ennek számos kiváltó oka lehet, pl. a fészkelőhely szükössége, a környező készletek kimerülése vagy a mikroklimatikus viszonyok kedvezőtlenebbé válása, de emellett az egyes kolóniák a költözés révén minimalizálhatják a fészekszomszédjaikkal való negatív interakciókat, a predációs- és parazita-nyomást, ill. a különböző fertőzéseket is (McGlynn 2012). A kolóniák bizonyos időközönkénti relokációja a szezonális polidómiával együtt nagyfokú instabilitást adhat a fészektérmintázatnak (Herbers 1985, 1989), amelynek relatíve gyors ütemü változása esetlegesen még akár a kolóniák közötti stabil kompetitív kapcsolatok kiépülését is meggátolhatja.

Természetesen számításba kell venni, hogy a kompetíció más típusú, így aggregált vagy véletlenszerü términtázat kialakulásához is vezethet, még akár a viszonylag homogénebb élőhelyeken is (Ryti 1991; Ryti és Case 1992; Adams és Tschinkel 1995). Jól példázzák mindezt pl. Sanders és Gordon (2000) vizsgálatai, akik két Myrmecocystus-faj, a M. mimicus és a $M$. depilis, valamint az A. cockerelli között erős interspecifikus kompetíciót mutattak ki annak ellenére, hogy a fészkek términtázata mindhárom faj esetében véletlenszerünek bizonyult, és az egyes fajok rendre közelebb fészkeltek heterospecifikus fészekszomszédjaikhoz. Ennek megfelelően, ahogyan a fészkek egyenletes térbeli eloszlása 
sem tekinthető önmagában véve a kompetíció egyértelmü bizonyítékaként (Ryti és Case 1992; Adams és Tschinkel 1995; Parr és Gibb 2010; McGlynn 2012), ugyanúgy a szegregáltság, ill. a denzitás és diszpergáltság pozitív kapcsolatának hiánya sem jelenti feltétlenül azt, hogy a kompetíció nem lényeges szervező erő az adott közösségben (Adams és Tschinkel 1995; Schooley és Wiens 2003).

\subsection{Táplálékszerzés tér-idő mintázata}

Számos eddigi vizsgálat alapján az egyes hangyafajok jellemzően tranzitív, lineáris dominancia hierarchiákba szerveződnek a közöttük kialakuló aszimmetrikus kompetíció eredményeként, mely hierarchiákon belül bármely szubordinált faj felett gyakorolt dominancia egyben ennek összes alárendeltje feletti dominanciát is jelenti (pl. Vepsäläinen és Pisarski 1982; Fellers 1987; Savolainen és Vepsäläinen 1988, 1989; Vepsäläinen és Savolainen 1990; Morrison 1996; Cerdá és mtsai. 1997, 1998a; Bestelmeyer 2000; Morrison és mtsai. 2000; LeBrun 2005; Wiescher és mtsai. 2011). Ezen hierarchiák megléte elviekben azzal a következménnyel járnia, hogy a rangsor legelején álló csúcskompetítorok az összes többi fajt kikompetálják, így tartós koegzisztenciára csupán akkor kerülhetne sor, ha bizonyos külső tényezők (pl. zavarás vagy stressz) a domináns fajok abundanciáját vagy a domináns és szubordinált fajok közötti interakciók erősségét csökkentenék (Palmer 2004; LeBrun 2005; Feener és mtsai. 2008). A szüntopikus hangyafajok együttélését, és így a lokális diverzitás fenntartását ugyanakkor számos kompenzáló mechanizmus segítheti elő, amelyek közül leginkább a különböző csereviszonyok (pl. Fellers 1987; Cerdá és mtsai. 1997; Davidson 1998; Bestelmeyer 2000; Stanton és mtsai. 2002; LeBrun és Feener 2007), valamint a készletek térben (pl. Savolainen és Vepsäläinen 1989; Albrecht és Gotelli 2001; Wittman és mtsai. 2010) vagy időben való felosztása (pl. Lynch és mtsai. 1980; Fellers 1989; Cerdá és mtsai. 1997; Albrecht és Gotelli 2001; Stuble és mtsai. 2013) tünik a leginkább meghatározónak, de emellett a kompetitív interakciók kimenetelét befolyásoló más egyéb tényezők (pl. a parazitoidok jelenléte, az élőhely komplexitásának mértéke, a táplálékforrás típusa, stb.) szerepe is fontos lehet (pl. Sanders és Gordon 2003; Gibb 2005; LeBrun 2005; Sarty és mtsai. 2006; LeBrun és Feener 2007).

Bár hangyáknál a dominancia-forrásfelfedezés trade-offot az egyik leggyakrabban előforduló csereviszonyként tartják számon (Fellers 1987; Davidson 1998; Feener 2000; LeBrun és Feener 2007), ennek meglétét, hasonlóan más vizsgálatokhoz (pl. Lessard és mtsai. 2009; Wiescher és mtsai. 2011; Parr és Gibb 2012; Stuble és mtsai. 2013) egyik általam 
vizsgált közösség esetében sem sikerült igazolni. Söt, a füredi tölgyesben éppen a nagyfokú viselkedésbeli dominanciát mutató fajok, azaz az A. subterranea és a $P$. nitens voltak azok, amelyek a legjobb felfedezési hatékonysággal rendelkeztek és a csalétkeket a legrövidebb idő alatt fedezték fel. Hasonló pozitív kapcsolatot a dominancia és a felfedező képesség között más hangyaközösségek esetében is leírtak már (Santini és mtsai. 2007; Parr és Gibb 2012), amely többek között kapcsolatba hozható az élöhely strukturáltságának hiányával, valamint a stabil szénhidrátforrást (pl. mézharmatot) kiaknázni képes, ökológiailag domináns fajok jelenlétével, amelyek a dominancia-forrásfelfedezés trade-offot „megszegni” képesek (Parr és Gibb 2012). Elképzelhető ugyanakkor, hogy az A. subterranea és a $P$. nitens esetében a jó felfedező képesség csupán látszólagos, és pusztán annak következménye, hogy ezek a legnagyobb abundanciával előforduló, leggyakoribb fajok az élőhelyen. Amennyiben ugyanis a különböző táplálékforrások felfedezése nagyrészt véletlenszerúen történik, a nagy számok törvénye alapján azok legnagyobb részén elsőként rendre az adott élőhely legabundánsabb fajai fognak megjelenni (Pearce-Duvet és mtsai. 2011; Cerdá és mtsai. 2013). A P. nitens esetében a jó felfedező képesség látszólagos mivoltát támasztja alá a fentiek mellett az is, hogy (1) szezonális aktvitása csúcsán, a hüvösebb tavaszi és őszi periódusban nagyrészt egyedüli fajként látogatta a csalétkeket, így nem meglepő módon a felfedezési hatékonysága is éppen ezen időszakok során volt a legnagyobb, valamint hogy (2) a csalétkek felfedezési ideje bár gyengén, de pozitívan korrelált azoknak a fészektől való távolságával, azaz minél közelebb helyezkedtek el a csalétkek a faj fészkeihez (vagy fészekkijárataihoz), a táplálékkereső dolgozók annál rövidebb idő alatt fedezték fel azokat.

Nagy általánosságban azt, hogy a dominancia és a felfedező képesség között fennáll-e csereviszony vagy sem, alighanem nagyban meghatározza az adott közösség fajösszetétele (Lessard és mtsai. 2009; Stuble és mtsai. 2013), ahogyan számos olyan tényező is, amelyek mind a dominancia mértékét, mind az egyes fajok felfedező képességét befolyásolhatják, kezdve a hőmérséklettől a parazitoidok jelenlétén át a táplálékforrás típusáig vagy az élőhely komplexitásának mértékéig (pl. Cerdá és mtsai. 1997; Bestelmeyer 2000; Gibb 2005; LeBrun 2005; LeBrun és Feener 2007; Gibb és Parr 2010; Parr és Gibb 2012). Ráadásul, mint azt Parr és Gibb (2012) vizsgálatai kimutatták, a dominancia-forrásfelfedezés trade-off összességében inkább tűnik kivételnek, mint szabálynak, és jelentőséggel csupán azokon az élőhelyeken bír, ahol a gazdaspecifikus parazitoidok a két életmenet jelleg kapcsolatát mediálják.

A dominancia-forrásfelfedezés trade-offhoz hasonlóan a dominancia és a hőmérsékleti tolerancia között fennálló csereviszony meglétét ugyancsak nem sikerült kimutatni a vizsgált közösségek egyikének esetében sem. Ennek oka, hogy az egyes gyakoribb fajok mindkét 
élőhelyen egymással nagymértékben átfedő hőmérséklet-tartományon belül látogatták a csalétkeket, és mindössze a maximális aktivitásuk hőmérsékleti intervallumában volt kimutatható némi különbség, mely azonban nem volt összefüggésbe hozható a viselkedésbeli dominanciájuk mértékével. A dominancia-hőmérsékleti tolerancia trade-off hiánya nagy valószínűség szerint azzal magyarázható, hogy ennek kialakulására inkább a nyíltabb, száraz élőhelyeken (pl. gyepeken, nyíltabb cserjésekben) lehet számítani, ahol jelentős a napi hőmérséklet-ingadozás (Cerdá és mtsai. 1997, 1998b; Bestelmeyer 2000; Wiescher és mtsai. 2011), míg a kiegyenlítettebb hőmérsékleti viszonyokkal rendelkező fás élőhelyeken kevésbé (Santini és mtsai. 2007; Wiescher és mtsai. 2011; Cerdá és mtsai. 2013), habár ez utóbbira is akad példa (pl. Lessard és mtsai. 2009).

A litéri fenyvessel ellentétben, ahol a csalétkeket látogató gyakoribb fajok közül csupán az A. subterranea és a Temnothorax-fajok szezonális aktivitásában volt kimutatható a vártnál szignifikánsan kisebb mértékü átfedés, a füredi tölgyesben az élőhely két ökológiailag domináns faját, az A. subterraneát és a $P$. nitenst is egymástól jelentős mértékben eltérő évszakos aktivitási ritmus jellemezte. Míg az A. subterranea szezonális aktivitásának csúcsát a nyár elején érte el, addig a $P$. nitens a hüvösebb tavaszi és őszi időszakban bizonyult a legaktívabbnak, aktivitása pedig az előző fajtól eltérően negatívan korrelált mind a lég-, mind a talajhőmérséklettel. Ehhez igen hasonló aktivitási mintázatot, ill. évszakos elkülönülést írtak le korábban a két faj észak-amerikai rokonfaja, az Aphaenogaster rudis és a $P$. imparis esetében is (Lynch és mtsai. 1980; Fellers 1989), amely alapján feltételezhető, hogy a jelenség hátterében a kontinentális különbségek ellenére is közös ökológiai háttérmechanizmusok húzódhatnak meg.

Minthogy a $P$. nitens a nyár eleji időszakban csupán igen alacsony aktivitást mutatott, sőt, a legmelegebb felvételezési napon egyáltalán nem is volt aktív, valószínűnek tűnik, hogy a kolóniái ez idő tájt egy rövidebb nyugalmi időszakra vonulnak, hasonlóan a $P$. imparishoz, amely földrajzi szélességtől függően néhány hétre, de akár több hónapra is inaktiválódhat az év melegebb szakában (Talbot 1943a, 1943b; Tschinkel 1987). Hogy a P. nitens esetében ez a nyugalmi időszak pontosan milyen hosszú lehet, az egyelőre kérdéses, mindenesetre az ezt megelőző évek csalétkes kísérletei alapján akár július végéig is elhúzódhat (Lőrinczi, nem publikált adat). Minthogy a faj utódnevelési időszaka éppen a nyár eleji hónapokra esik (Andrásfalvy 1961), amikor is tehát a táplálékkereső dolgozókat igen alacsony felszín feletti aktivitás jellemzi, a $P$. imparishoz hasonlóan a lárvák táplálását ennél a fajnál is feltehetőleg nagyrészt a tavasszal nagy mennyiségü tartalék tápanyagot felhalmozó mézesbödön-dolgozók végezhetik. Az utódneveléssel esetlegesen az is összefüggésben állhat, hogy míg más 
domináns fajok (pl. A. subterranea, L. emarginatus) évszaktól függetlenül rendre a fehérjedús táplálékforrást (tonhalat) részesítették előnyben, addig a $P$. nitens táplálékpreferenciája jellegzetes szezonális változást mutatott, és az egyes kolóniák csupán ebben az alacsony aktivitású nyár eleji időszakban rekrutáltak szignifikánsan több dolgozót a tonhalra. A P. nitens sajátos szezonális aktivitásának fényében már az is könnyebben értelmezhető, hogy a fészkeinek (vagy fészekkijáratainak) denzitása miért éppen a nyár elején volt a legalacsonyabb, mely időszak során tehát a kolóniák legnagyobb része feltehetőleg a talaj mélyebb rétegeibe húzódik, a fészekkijárataikat pedig lezárják.

$\mathrm{Az}$ évszakos aktivitással ellentétben a csalétkeket látogató gyakoribb fajok napi aktivitásában egyik élőhelyen sem volt megfigyelhető jelentős elkülönülés, sőt, az átfedés mértéke többnyire a vártnál szignifikánsan nagyobb mértékű volt. Elképzelhető, hogy ennek oka részben abban keresendő, hogy a tartós táplálékforrást imitáló csalétkek attraktivitásuknál fogva megváltoztatták, mintegy „uniformizálták” a látogató fajok természetes napi aktivitási mintázatát. Ehhez hasonlót dokumentált Mercier és Dejean (1996) két szüntopikus afrikai hangyafaj, a Camponotus brutus és a Polyrhachis laboriosa esetében, amelyek közül elöbbi tartós táplálékforrás (pl. mézharmat) jelenlétében éjszakairól egész napos aktivitásra váltott át, aminek következtében már jelentős mértékben ütközött a nappali életmódú Polyrhachis-fajjal. Minthogy azonban jelen vizsgálatok során a felvételezések csupán a nappali órákra korlátozódtak, sokkal valószínűbbnek tünik, hogy ez a 10-12 órás időtartam egyszerüen túl rövid volt ahhoz, hogy az esetleges napi aktivitásban való elkülönülést ki lehessen mutatni. Az egy adott élöhelyen együtt élő hangyafajok ugyanis a tekintetben, hogy a nap mely szakában (ti. hogy nappal vagy éjszaka) aktívak, jelentős mértékben különbözhetnek (Hunt 1974; Gallé 1979, 1986; Vepsäläinen és Savolainen 1990; Cerdá és mtsai. 1997, 1998a; Santini és mtsai. 2007; Stukalyuk és Radchenko 2011; Stuble és mtsai. 2013), ráadásul a napi aktivitási mintázat bizonyos fajok esetében akár szezonálisan is változhat (Lynch és mtsai. 1980; Fellers 1987, 1989; Cros és mtsai. 1997; Albrecht és Gotelli 2001). A kimondottan a nappali órákban mutatott jelentősebb időbeli elkülönülés viszont tipikusan inkább az olyan élőhelyeken fordul elő, amelyeket szélsőséges klimatikus viszonyok (pl. szárazság, nagy hőmérséklet-ingadozás, stb.) jellemeznek, és ahol az extrém hőtürő fajok napi aktivitásuk csúcsát a legmelegebb déli órákban érik el, amikor más fajok aktivitása minimális vagy teljesen meg is szünik (pl. Cerdá és mtsai. 1997, 1998b; Cros és mtsai. 1997).

A térbeli elkülönülés jelentőségét látszik igazolni, hogy a csalétkeken regisztrált fajok mindkét élőhelyen jelentős mértékben különböztek a tekintetben, hogy a talajon vagy fákon elhelyezett csalétkeket látogatták-e nagyobb arányban. Mint azt korábbi vizsgálatok is 
kimutatták, a különböző vertikális szinteken történő táplálékkeresés nem csupán a domináns és szubordinált fajok tartós együttélését, de a rangsorban egymáshoz közelebb álló domináns fajok koegzisztenciáját is nagymértékben elősegítheti (Gallé 1979, 1986; Savolainen és Vepsäläinen 1989; Stukalyuk és Radchenko 2011). A vertikális elkülönülés különösen a füredi tölgyesben volt kifejezett, ahol az egyébként talajszinten fészkelö Lasius-fajok (L. emarginatus, L. brunneus) mellett az olyan arboreális életmódú, agresszív, territoriális fajok, mint a $C$. schmidti vagy a $L$. microcephalum is csupán elvétve fordultak elő a talajon elhelyezett csalétkeken, így mindössze néhány alkalommal ütköztek csak más, nagyrészt a talajfelszínen mozgó fajokkal. Bár az olyan funkcionális csoportok képviselői, mint a domináns Dolichoderinae vagy a generalizált Myrmicinae, amelyeket itt utóbbi két faj reprezentál bizonyos földrajzi régiókban (pl. Ausztráliában vagy Észak-Amerikában) nagy abundanciájuk és viselkedésbeli dominanciájuk miatt meghatározó szerepet játszanak a hangyaközösségek strukturálásában (Andersen 1995, 1997, 2010), ezen az élőhelyen látszólag egyikük sem gyakorol jelentős hatást a talajszinten élő opportunista (pl. A. subterranea, $F$. gagates), ill. hidegtürő klímaspecialista ( $P$. nitens) fajok egyikére sem. Ennek oka alighanem nagyrészt abban keresendő, hogy mind a $C$. schmidti, mind a L. microcephalum táplálkozási territóriumának legnagyobb része a fák lombkoronájára terjed ki, és a kolóniáik a talajfelszínt jobbra csak mintegy „,tranzit zónaként” használják (Petráková és Schlaghamerský 2011; Stukalyuk és Radchenko 2011).

A vertikális elkülönülés mellett számos gyakoribb fajpáros esetében a csalétkeken való együttes előfordulás mértéke a vártnál szignifikánsan kisebb volt azokra az időszakokra nézve, amikor az illető fajpáros mindkét tagja viszonylag nagyobb aktivitást mutatott. Hasonló, a csalétkeken mutatott térbeli szegregációt más vizsgálatok során is dokumentáltak már (pl. Albrecht és Gotelli 2001; Wittman és mtsai. 2010; Cerdá és mtsai. 2012), amely vagy ezen fajok táplálkozási területének kismértékü átfedésére, esetleg egymás kölcsönös kerülésére utal, vagy sokkal inkább arra, hogy az illető fajok az általuk elfoglalt csalétkeket sikerrel monopolizálni tudták.

Bár kérdéses, hogy a mesterséges táplálékforráson megfigyelhető egyedi viselkedések milyen mértékben tükrözik a populációs, ill. közösségi szinten zajló folyamatokat (Parr és Gibb 2010), mindenesetre a csalétkeken mutatott nagyszámú, gyakran kizárással végződő agonisztikus interakció a táplálékkészletekért folyó kompetíció jelentőségére látszik utalni ezeken az élőhelyeken. E tekintetben különösen az agresszív, nem territoriális fajok szerepe tünik a leginkább meghatározónak, amelyek feltehetőleg már pusztán abundanciájuknál fogva is erős kompetíciós nyomást gyakorolhatnak más fajokra, ezáltal nagyban strukturálva a 
közösséget számos más olyan élőhely esetében tapasztaltakhoz hasonlóan, ahol a territoriális fajok hiányában szintén az egyébként a hierarchia alsóbb szintjén elhelyezkedő szubdomináns fajok minősülnek dominánsnak (Lynch és mtsai. 1980; Fellers 1987, 1989; Cerdá és mtsai. 1997; Lessard és mtsai. 2009; Stukalyuk és Radchenko 2011; Stuble és mtsai. 2013).

Jóllehet az Aphaenogaster-génusz tagjait tipikusan szubmisszív fajokként tartják számon (pl. Fellers 1987; Cerdá és mtsai. 1997; Holway 1999), a legtöbb agresszív megnyilvánulás és csalétekről való kizárás mindkét élőhelyen az A. subterraneához volt köthetö, amely nem csupán a szubordinált fajokra (Serviformica spp., Temnothorax spp.) gyakorolt erőteljes nyomást, de nem várt módon még az olyan fajokkal szemben is jelentős agressziót mutatott, mint a $C$. ligniperdus vagy a L. microcephalum. Az A. subterranea ezeken az élöhelyeken mutatott nagyfokú viselkedésbeli dominanciájára (1) nagy lokális abundanciája, ill. gyakori előfordulása (azaz számbeli dominanciája), (2) a hasonló viselkedésbeli dominanciát mutató fajoktól (pl. P. nitens, L. emarginatus) való tér- és/vagy időbeli (szezonális) elkülönülése, valamint (3) az agresszív, territoriális fajok (füredi tölgyes: L. microcephalum, C. schmidti; litéri fenyves: F. pratensis) csekély mértékü jelenléte és/vagy hatása szolgálhat magyarázatul. Azt, hogy ezen faj viselkedésbeli dominanciájának mértéke nagymértékben kontextusfüggő, jól példázza Stukalyuk és Radchenko (2011) a Krímihegységben végzett vizsgálata, amely szerint a terület erdős élöhelyein az A. subterranea alárendelt pozíciót tölt be a jobbára a L.emarginatus és F. gagates által dominálta közösségekben.

Noha jelen vizsgáltok alapján a szubordinált fajok ezeken az élöhelyen nem rendelkeznek a domináns fajokénál jobb felfedező képességgel vagy nagyobb hőmérsékleti toleranciával, az általuk alkalmazott ún. elkerülő stratégiáknak ugyanakkor meghatározó szerepe lehet az utóbbiakkal való koegzisztenciájuk során. Ilyen volt megfigyelhető pl. a csalétkeken rendre más fajokkal együtt előforduló Temnothorax-fajok esetében, amelyek apró termetük, ill. a csalétkekre rekrutált kis dolgozószámuk miatt többnyire nem váltottak ki agressziót más fajok képviselőiből, támadás esetén pedig gyakran csupán „lekuporodtak”, majd teljesen mozdulatlanná váltak, hasonlóan a génusz más tagjaihoz, ill. a közel rokon Leptothorax-fajokhoz (Lynch és mtsai. 1980; Vepsäläinen és Pisarski 1982; Fellers 1987; Savolainen és Vepsäläinen 1989). Egy egészen másfajta taktikát képviselt a gyors mozgású Serviformica-fajok ún. „menekülő-visszatérő” stratégiája (Mercier és Dejean 1996), amelynek értelmében dolgozóik az agresszívabb fajok által történő kizárásukat követően szinten azonnal vissza is tértek a csalétkekre, hogy aztán újból megkíséreljenek hozzáférést nyerni a táplálékforráshoz. A két Serviformica-faj, a $F$. fusca és a $F$. gagates csalétkeken mutatott 
viselkedése azonban több szempontból is nagyban különbözött egymástól. Míg a $F$. fusca az esetek döntő többségében tipikus szubmisszív fajként viselkedetett, és számbeli dominanciája ellenére sem rekrutált egyszerre néhány dolgozónál többet az általa látogatott csalétkekre, addig a $F$. gagates részéről több alkalommal is megfigyelhető volt agresszív megnyilvánulás, ráadásul dolgozói az általuk elsőként felfedezett csalétkeket néhány esetben képesek voltak relatíve nagy egyedszámmal elfoglalni és monopolizálni. A Serviformica-alnem egy másik képviselőjéhez, a Formica cinereához hasonlóan, amely élőhelytől függően domináns és szubordinált faj is lehet egyaránt (Gallé 1991; Markó és Czechowski 2004; Czechowski és Markó 2005), a F. gagates dominancia hierarchiában betöltött pozíciója is nagymértékben kontextusfüggőnek tünik jelen vizsgálat alapján, amelyet Stukalyuk és Radchenko (2011) fentebb már említett vizsgálata is megerősíteni látszik.

Annak ellenére, hogy a dominancia rangsorrendje alapján a domináns és szubordinált fajok mindkét élőhelyen viszonylag jól elkülönültek egymástól, a dominancia-hierarchia linearitása egyik esetben sem különbözött szignifikánsan a véletlenszerütől. Noha a tranzitív, lineáris hierarchiákkal szemben a különböző intranzitív hálózatok a közösségek szerkezetét stabilizálhatják az egymással kompetáló fajok koegzisztenciájához vezethetve (Savolainen és Vepsäläinen 1989; Sanders és Gordon 2003; LeBrun 2005), a vizsgált közösségek esetében ennek jelentősége elhanyagolhatónak tűnik. Az egyes fajok rangsorba rendezését követően kapott mátrixok sajátos elrendeződése (ti. az intranzitív interakciók, azaz a nullák hiánya a mátrix jobb felső felében) ugyanis sokkal inkább arra utal, hogy a statisztikailag igazolható linearitás hiánya pusztán a nem ismert dominanciaviszonyok viszonylag nagy számának tudható be, lévén bizonyos fajpárok tagjai az erős térbeli szegregáció és/vagy a kevésbé gyakori előfordulásuk miatt nem konfrontálódtak a csalétkeken (vö. Morrison 1996; Cerdá és mtsai. 1997, 1998a; Morrison és mtsai. 2000).

\subsection{Prenolepis nitens téli aktivitása}

Bár a hangyák többsége jellemzően a $10^{\circ} \mathrm{C}$ és $45^{\circ} \mathrm{C}$ közötti hőmérsékleti tartományban mutat aktivitást (Hölldobler és Wilson 1990), számos faj esetében alakult ki nagyfokú hö- vagy éppen hidegtürő képesség, amelynek révén az igen magas vagy a kedvezötlenül alacsony hőmérsékleteket is képesek tartósan elviselni. Ezek közül az ún. extrém termofil fajok a leginkább ismertek, amelyek aktivitásukat akár $45^{\circ} \mathrm{C}$ és $70{ }^{\circ} \mathrm{C}$ között is megőrizik, vagy, mint az egyes sivatagi fajok (pl. M. bagoti) esetében jellemző, aktivitásuk csúcsát egyenesen ezen preferendumon belül érik el (pl. Bernstein 1979; Marsh 
1985; Christian és Morton 1992; Bestelmeyer 1997; Cerdá és mtsai. 1998b). A kriofilia, azaz az alacsonyabb hőmérsékletek preferenciája a termofiliával ellentétben már egy kevésbé jól dokumentált jelenség a hangyák körében. Erre láthatunk példát egynéhány olyan faj esetében, mint pl. a P. imparis (Talbot 1943a, 1943b), a Camponotus vicinus (Bernstein 1979) vagy a Prionomyrmex macrops (Hölldobler és Taylor 1983), mely fajok már igen alacsony hőmérsékleteken, akár fagypont közelében is képesek aktívan táplálékot keresni, míg ezzel szemben aktivitásuk $20^{\circ} \mathrm{C}$ felett már jelentősen visszaesik. Amellett, hogy ezen termo-, ill. kriofil fajok nagyfokú hö- vagy hidegtürő képességük miatt elkerülhetik potenciális kompetítoraikat (Hölldobler és Taylor 1983; Bestelmeyer 1997; Cerdá és mtsai. 1997, 1998b), táplálkozási sikerüket is nagyban megnövelhetik azáltal, hogy táplálékukat a magas vagy éppen alacsony hőmérséklet következtében elpusztult vagy inkapacitált zsákmányállatokkal egészíthetik ki (Talbot 1943b; Hölldobler és Taylor 1983; Marsh 1985).

Annak ellenére, hogy az Észak-Amerikában közkeletűen csak „téli hangyának” nevezett $P$. imparis esetében már igen régóta közismert, hogy aktivitását télen is megőrzi (Wheeler 1930; Talbot 1943a, 1943b; Tschinkel 1987; Fellers 1989), európai testvérfaja, a $P$. nitens esetében mindezidáig még nem dokumentáltak hasonló nagyfokú toleranciát a hideggel szemben. Bár egyes korábbi megfigyelések a $P$. nitens kora tavaszi nászrepülésére (Röszler 1937; Andrásfalvy 1961; Bregant 1998), valamint az alpesi régióban való előfordulására vonatkozóan (Steiner és Schlick-Steiner 2001) a faj alacsony hőmérsékleti igényére engedtek következtetni, Seifert (2007) a P. nitenst egyenesen a téli hidegre érzékeny fajként jellemezte, kihangsúlyozva ugyanakkor, hogy a tavasztól őszig tartó aktivitása idején nem kifejezetten melegkedvelő. Jelen vizsgálatok alapján viszont egyértelmünek tünik, hogy legalábbis a Balaton-felvidéki élőhelyén a faj nem csupán hogy a szezonális aktivitásának csúcsát a hüvösebb tavaszi és őszi periódusban éri el, de emellett a $P$. imparishoz hasonlóan a téli hónapokra sem vonul valódi hibernációba, hanem aktivitását más szüntopikus hangyafajoktól eltérően egész télen megőrzi.

A $P$. nitens téli aktivitása során elsősorban a talajhőmérséklet tünik a leginkább meghatározónak, amelyet jól mutat, hogy a márciusi felvételezések ideje alatt hiába volt viszonylag magasabb $\left(7^{\circ} \mathrm{C}\right.$ és $9^{\circ} \mathrm{C}$ közötti) az átlagos léghőmérséklet, a dolgozók aktivitása ennek ellenére mégis viszonylag alacsony maradt. Ennek oka feltehetőleg az lehet, hogy ezeken az évszakhoz képest szokatlanul hideg márciusi napokon a dolgozók az éjszakai és kora reggeli rendszeres fagyok miatt még dermedt talajt a relatíve magas léghőmérséklet ellenére sem hagyták el mindaddig, amíg az fel nem engedett kissé. 
Noha egynéhány dolgozó már az $1{ }^{\circ} \mathrm{C}$ körüli hőmérsékleteken is aktívnak bizonyult, jelentősebb aktivitásnövekedés csupán azután volt megfigyelhető, miután mind a lég-, mind a talajhőmérséklet tartósan $3-4{ }^{\circ} \mathrm{C}$ fölé emelkedett. A P. nitens ebben a tekintetben is nagyfokú hasonlóságot mutat észak-amerikai testvérfajával, amelynek dolgozói Talbot (1943b) vizsgálataiban ugyan már fagypont környékén elhagyták fészküket, aktivitásuk azonban csupán $2{ }^{\circ} \mathrm{C}$ és $4{ }^{\circ} \mathrm{C}$ között kezdett el jobban növekedni.

A kiskvadrátos felvételezések során több alkalommal is sikerült olyan táplálékkereső dolgozókat megfigyelni, amelyek rágóik között valamilyen zsákmányállatot (többnyire ugróvillásokat) szállítottak. Ez alátámasztani látszik Talbot (1943b), ill. Hölldobler és Taylor (1983) azon feltételezését, mely szerint az alacsony, fagypont közeli hőmérsékleteken való aktivitás a fagy következtében elpusztult vagy lassabban mozgó kisebb gerinctelenek (pl. férgek, pókok, százlábúak, rovarok stb.) zsákmányul ejtését is lehetővé teszi a hangyák számára ezen időszak során. Annak oka, hogy a csalétkeket látogató dolgozók ugyanakkor a tonhallal szemben inkább a mézet preferálták feltehetőleg abban keresendő, hogy az egyébként nagyrészt különféle édes nedveket (pl. mézharmatot, nektárt, ill. gyümölcsök nedveit) fogyasztó faj számára a téli időszakban alighanem nagyon kevés vagy szinte semmilyen szénhidrátban gazdag táplálékforrás nem áll rendelkezésére.

Felmerül a kérdés, hogy alacsony hőmérsékleti igénye ellenére mivel magyarázható a $P$. nitens viszonylag szük földrajzi elterjedése Európában. A P. imparisszal ellentétben ugyanis, amely Észak-Amerikában Kanada déli részétől Mexikóig, a nyugatitól a keleti partig előfordul (Wheeler 1930; Tschinkel 1987), a P. nitens elterjedési területe nagyrészt DélkeletEurópára, ill. a Fekete-tenger térségére korlátozódik (Wheeler 1930; Bregant 1998; Vesnić és Lelo 2010). Wheeler (1930) szerint a P. nitens feltehetőleg a negyedidőszaki eljegesedés során tủnt el Európa északi és nyugati részéről, lévén az Alpok vonulata mintegy természetes barriert képezve megakadályozta az itt élő populációinak fokozatos délre húzódását, ahogyan egy későbbi felmelegedési periódust követően a túlélő délkeleti populációinak északi irányú visszaterjedését is, amelyek így aztán azt a szűk areát népesítették be, ahol a faj jégkori reliktumként ma is előfordul. Mindezek alapján tehát igen valószínünek tủnik, hogy a $P$. nitens nagyfokú hidegtürő képessége nem más fajok kompetíciós nyomásának, hanem sokkal inkább a faj hidegebb klimatikus viszonyokhoz való természetes adaptációjának eredményeként alakulhatott ki egy korábbi földtörténeti időszak során. 


\subsection{Aphaenogaster subterranea eszközhasználata}

A Formicinae és Dolichoderinae alcsaládok képviselőivel szemben, amelyek esetében a tágulékony begy és a módosult előgyomor (proventriculus) nagy mennyiségü folyékony táplálék felvételét, raktározását és gyors emésztését teszi lehetővé (Eisner és Brown 1958; Davidson és mtsai. 2004), az Aphaenogaster-fajoknál a Myrmicinae alcsalád többi tagjához hasonlóan nem alakultak ki a fentiekhez hasonló adaptív bélyegek. Ezt jól mutatja, hogy míg pl. az A. rudis dolgozói a begyükben a testtömegüknek mindössze 10\%-át kitevő folyékony táplálékot képesek raktározni és szállítani (Fellers és Fellers 1976), addig ez a szüntopikus Formicinae-faj, a P. imparis esetében akár a 130-200\%-ot is elérheti (Lynch és mtsai. 1980). A Myrmicinae alcsalád egyes génuszainak (pl. Aphaenogaster, Messor, Pogonomyrmex) képviselői ráadásul másodlagosan a trofallaxisra való képességüket is elvesztették (Agbogba 1985), mely folyamat lehetővé tenné, hogy a fészekbe visszatérő dolgozók a begyükben szállított folyékony táplálékot fészektársaikkal is megosszák. Feltehetőleg ezen hiányosságok kompenzálására alakulhatott ki az Aphaenogaster-génusz számos tagjainál, ill. néhány más Myrmicinae-fajnál (pl. P. badius) az eszközhasználatnak az a formája, amelynek során a dolgozók a folyékony táplálék elszállításához különböző, a környezetükben fellelhető szilárd anyagokat (pl. talajszemcséket, levéldarabokat, stb.) használnak fel úgy, hogy azokat a folyadék felszínére (pl. édes nedvekre, ízeltlábúak kifolyó hemolimfájára, stb.) hordják, majd az így impregnált „eszközöket” szállítják vissza a fészkükbe, ahol aztán a többi dolgozó lenyalogathatja róluk a rájuk tapadt táplálékot (Fellers és Fellers 1976; Agbogba 1985).

Ezt a sajátos viselkedésformát ez idáig a génusz nyolc faja esetében dokumentálták már, beleértve az A. subterraneát is (Fellers és Fellers 1976; Tanaka és Ono 1978; Fowler 1982; McDonald 1984; Agbogba 1985; Cerdá és mtsai. 1988; Banschbach és mtsai. 2006), bár ez utóbbinál eddig csupán laborban tartott kolóniák esetében (Agbogba 1985). Mint arra Fellers és Fellers (1976), ill. McDonald (1984) rámutatott, ez az eszközhasználó viselkedés alighanem abból a magatartásformából alakulhatott ki, amelyet a legtöbb hangyafaj mutat, mikor a fészkük közelében lévő mozdíthatatlan, a kolónia számára potenciális veszélyt (pl. a fészkük elárasztásának és/vagy a dolgozók belefulladásának, beleragadásának lehetőségét) jelentő folyadékfelületeket hordanak be különböző anyagokkal (Wheeler 1910). Ez többek között magyarázatul szolgálhat arra, hogy a tápláléknak minősülő folyadékok viszkozitásának csökken(t)ésével miért fokozódik az azokra való ráhordás intenzitása (Tanaka és Ono 1978).

Míg Banschbach és mtsai. (2006) terepi felvételezései során az A. rudis esetében csupán az esetek 65-95\%-ban fordult elő, hogy a dolgozók ráhordást végeztek a látogatott 
csalétkeken, addig ez az A. subterraneára mind a jelen vizsgálat, mind az összes, ezt megelőzően végzett csalétkes vizsgálat során kivétel nélkül minden esetben jellemző volt. A ráhordás rendszerint röviddel a csalétek felfedezése után azonnal meg is kezdődött, és csupán néhány kivételes esetben volt jellemző, hogy a dolgozók nagy egyedszámmal lepték el a csalit, és kezdtek el táplálkozni rajta (mint azt ahogyan pl. a Myrmica-fajok teszik), azonban még ezen alkalmakkor is hamarosan megjelentek a ráhordást végző dolgozók, amelyek a táplálkozó egyedeken átbukdácsolva kezdték el a táplálék felületének behordását.

Bár más Aphaenogaster-fajokhoz hasonlóan az A. subterranea dolgozói által mutatott eszközhasználat is alapvetően három, időben elkülönülő, rendszerint más-más dolgozók által végzett fázisra különült (ráhordási-, pozícionálási- és szállítási fázis) (pl. Fellers és Fellers 1976), egyetlen esetben sikerült egy olyan dolgozót megfigyelni (és egyúttal videofelvételen rögzíteni), amely a csalétekre érkezve az általa hordozott „eszközt” nem helyezte rá a táplálékra, hanem ehelyett a rágói között tartva kezdte azt el mártogatni, majd az így impregnált „eszközt” rögtön el is szállította. Hasonló egyedi viselkedést az eszközhasználat szempontjából legalaposabban vizsgált Aphaenogaster-faj, az A. rudis esetében sem figyeltek meg még eddig (Banschbach, szóbeli közlés), ami felveti annak kérdését, hogy ez az ún. „közvetlen” eszközhasználat vajon egyfajta fajspecifikus magatartásformát képvisel-e vagy előfordulása csupán túlságosan ritka ahhoz, hogy a kísérletek során jó eséllyel detektálni lehessen.

Annak ellenére, hogy az A. subterranea „eszközökkel” foglalatoskodó dolgozóinak egyedszáma a csalin táplálkozó és különösebb tevékenység nélkül jelenlévő dolgozók egyedszámával viszonylag jól korrelált, előbbiek összességében még így is rendszerint csupán töredék részét tették ki az egyes csalétkeken tartózkodó összes egyednek. Ez összhangban van azzal, amelyet $A$. rudis esetében mutattak ki, miszerint az eszközhasználat egy olyan specializált feladattípust jelent, amelyet kolóniamérettől függetlenül rendre a táplálékkereső dolgozók egy kisszámú, de a feladatot igen jó hatékonysággal ellátó csoportja végez (Banschbach és mtsai. 2006). Az A. subterranea esetében az eszközhasználó dolgozók hatékonyságát jól mutatta, hogy megfelelő szintű aktivitás esetén ezek az egyedek néhány órán belül képesek voltak szinte maradéktalanul az összes, rendelkezésükre álló táplálékot a fészkükbe szállítani (Függelék 2. ábra).

Noha a vizsgálatok során a szük egypercesre szabott felvételezési idő miatt nem volt lehetőség a csalira hordott „eszközök” típusának pontos meghatározására, az azonban megfigyelhető volt, hogy az ráhordást végző dolgozók rövid keresgélés után rendszerint a csalilaphoz legközelebb eső, legkönnyebben mozdítható anyagokat használták fel, függetlenül 
azok látszólagos méretétől. Mint azt az Aphaenogaster famelica és az A. rudis esetében is kimutatták, a dolgozók a laboros kísérletek során bizonyos „eszközöket” valóban jobban preferáltak a többinél, feltehetöleg az alapján választva ki öket, hogy azok mennyire könnyen mozdíthatóak és milyen mennyiségü folyékony táplálék tud megtapadni a felületükön (Fellers és Fellers 1976; Tanaka és Ono 1978). Emellett ugyanakkor az egyes fajok természetes élőhelyén az is nagyban meghatározó lehet, hogy a különböző „eszközként” potenciálisan felhasználható anyagok közül melyek fordulnak elő és ezek milyen mennyiségben állnak a dolgozók rendelkezésére (Fellers és Fellers 1976).

Az eszközhasználat egyik fő adaptációs előnye, hogy ezáltal a táplálékkereső dolgozók jóval nagyobb mennyiségü folyékony táplálékot képesek a fészekbe szállítani, mintha azt „belsőleg”, a begyükben raktározva tennék, így pl. az A. rudisnál a dolgozók testtömegével megegyező mennyiségüt (Fellers és Fellers 1976), míg az A. famelica esetében akár annak 1,3-3,5-szeresét is (Tanaka és Ono 1978). Az „eszközökkel” foglalatoskodó dolgozók aktivitását, és ennek megfelelően az elszállított táplálék mennyiségét azonban feltehetőleg nagyban befolyásolhatják az olyan tényezők is, mint pl. a kolónia mérete (McDonald 1984; Banschbach és mtsai. 2006), a kolónia táplálékszükséglete (McDonald 1984; Barber és mtsai. 1989; Banschbach és mtsai. 2006) vagy a királynő jelenléte/hiánya (Agbogba 1985).

Az eszközhasználat emellett nagyban megnövelheti az eszközhasználó faj kompetíciós sikerét is, lévén a dolgozóknak nem szükséges tartósan a táplálékforráson tartózkodniuk, így az onnét más fajok képviselöit agresszív módon kizáró domináns fajokkal való ütközést is jelentősen minimalizálhatják. Fellers és Fellers (1976) terepkísérleteiben pl. az A. rudis a domináns fajok jelenlétében is végezte a táplálékra való ráhordást, majd ezt követően rögtön vissza is vonult, és csupán az előbbi fajok távozását követően tért vissza az impregnált „eszközökért”, ezáltal jelentősen kisebb kockázatot vállalva, mint folyamatos táplálkozás esetén. A jó felfedező képesség, a szubmisszív stratégia vagy a nagyfokú hőmérsékleti tolerancia mellett tehát az eszközhasználat egy újabb módja lehet annak, amelynek révén a szubordinált hangyafajok olyan táplálékforrásokat is hasznosíthatnak, amelyekről egyébként a domináns fajok kizárnák őket, sőt, a folyékony táplálék felületének behordása egyúttal akár el is tántoríthat más fajokat attól, hogy oda további dolgozókat rekrutáljanak (Fowler 1982; Banschbach és mtsai. 2006). Bár az általam vizsgált közösségekben az A. subterranea ökológiailag domináns fajnak számít, így az A. rudis által követett „beférkőző” stratégiát egyik csalétkes vizsgálat alkalmával sem sikerült megfigyelni, az azonban több esetben is jellemző volt, hogy a dolgozók akkor is megkezdték a csalira való ráhordást, amikor azon más 
hangyafajok képviselői tartózkodtak. Emellett néhány kivételes esetben, amikor a dolgozók olyan agresszív fajokkal ütköztek a csalétkeken, mint pl. a L. microcephalum, bár a csalétek tonhal felöli részének feladására kényszerültek, ám a különböző növényi törmelékkel és talajszemcsékkel telihordott mézcseppet még órákon át védeni tudták.

Vizsgálataim során az A. subterranea kolóniák több mint fele esetében volt megfigyelhető, hogy a dolgozók a petrolátumra is végeztek ráhordást, igaz egyetlen esetben sem olyan mennyiségben vagy intenzitással, mint a táplálékforrásul szolgáló mézcseppekre. Hasonló reakciót dokumentált terepkísérletei során McDonald (1984) is az Aphaenogaster albisetosa esetében, amelynek dolgozói nem csupán a higított mézre, hanem a desztillált vízre is hordtak rá anyagokat, bár csupán a fészküktől egy bizonyos távolságig. A különböző laboros vizsgálatok ugyanakkor a fentiekkel ellentétben sem az Aphaenogaster senilis és az A. subterranea (Agbogba 1985), sem az A. rudis (Banschbach és mtsai. 2006) esetében nem mutattak ki hasonlót, azaz a dolgozók még a fészkük közvetlen közelében sem végeztek ráhordást a különböző, táplálékforrásul nem szolgáló anyagokra (vízre, ill. petrolátumra), ami arra utal, hogy a Wheeler (1910) által leírt, a kolónia vagy a táplálékkereső dolgozók számára potenciális veszélyt jelentő folyadékokra adott reakció (ld. fentebb) nagymértékben faj-, ill. kontextusfüggő lehet.

Természetesen felmerül annak kérdése, hogy természetes körülmények között mikor, ill. milyen gyakorisággal kerül sor eszközhasználatra az Aphaenogaster-fajok esetében. Erre adhatnak választ Banschbach és mtsai. (2006) terepi vizsgálatai, amelyekben kimutatták, hogy az A. rudis fészekbe visszatérö dolgozói által szállított anyagoknak egy kicsi, de nem elhanyagolható százalékát rendre különbözö, potenciális „eszközként” szolgáló anyagok (pl. talajrögök, levél- és kéregdarabkák, stb.) tették ki, valamint Fellers és Fellers (1976), ill. Agbogba (1985) laboros kísérletei, amelyek során a különböző Aphaenogaster-fajok dolgozói elpusztult ízeltlábúak (pókok, rovarok) kifolyó testnedvei esetében is ugyanúgy végeztek ráhordást és szállítást. Mindezek arra utalnak, hogy ezt a sajátos viselkedésformát a génusz tagjai nem csupán mesterséges körülmények között és/vagy szénhidrátban gazdag táplálékforrás (pl. méz vagy cukrozott víz) jelenlétében mutatják, hanem ténylegesen szerves részét képezheti ezen fajok természetes táplálékszerző stratégiájának.

\subsection{Aphaenogaster subterranea asszociációja recéskabócákkal}

Noha a bordásfejükabóca-alkatúak (Fulgoromorpha) alrendjén belül legalább tíz család esetében is ismert a hangyák és kabócák között kialakuló kapcsolat valamely formája, 
beleértve a recéskabóca-félék (Cixiidae) családját is (China és Fennah 1952; Hoch 1990; Delabie 2001), a téma szakirodalma összességében kifejezetten szegényesnek mondható. Kivételt ez alól csupán a bőröskabóca-félék (Tettigometridae) jelentenek, mely család tagjainak hangyákkal való kapcsolata csaknem a háromnegyedét teszi ki az alrenden belüli eddig dokumentált hangya-kabóca asszociációknak (Bourgoin 1997; Dejean és Bourgoin 1998; Dejean és mtsai. 2000; Lehouck és mtsai. 2004).

A hangyák és a Cixiidae család képviselőinek kapcsolatát feltáró vizsgálatok meglehetően ritkák, ráadásul az eddig leírt esetek legnagyobb része is csupán egyszerü megfigyeléseken alapszik, amelyek alapján mindössze feltételezhető a lehetséges asszociáció az egyes felek között (pl. Myers 1929; Thompson és mtsai. 1979; Neece 1980). Ezen interakciókban jellemzően a kabócák nimfái (Myers 1929; Mitjaev 1967; Thompson és mtsai. 1979; Thompson 1984), és csak kivételesen maguk a kifejlett egyedek vesznek részt (Holzinger 2009). Közép-Európában a Reptalus- és a Pentastiridius-fajok azok, amelyek mürmekofil életmódjukról ismertek a családban (Holzinger, szóbeli közlés), ugyanakkor az, hogy ezek mely hangyafajokkal állnak kapcsolatban, ill. hogy ezen interakciók mennyire gyakoriak és milyen fokú asszociációt képviselnek mindezidáig tisztázatlan maradt.

Annak egyik oka, hogy eddig ilyen kevés hangya-recéskabóca kapcsolatot írtak le feltehetőleg az lehet, hogy utóbbiak kevés olyan adaptív tulajdonsággal rendelkeznek, amelyek elősegítenék a hangyákkal való tartós együttélés kialakulását. A recéskabócákkal ellentétben a Tettigometridae család tagjai esetében pl. számos morfológiai és viselkedésbeli adaptáció teszi ezt lehetővé, ilyen pl. a viaszos védőréteg, ill. az ugróképesség hiánya, a nagyrészt helytülő életmód, valamint az erős csoportosulási hajlam (Bourgoin 1997). Tartós hangya-Fulgoromorpha kabóca kapcsolat ugyanakkor nem csupán abban az esetben alakulhat ki, ha a kabócapartner szesszilis és/vagy szubszociális életmódú, hanem akkor is, ha a kabócaegyedek szétszéledése és/vagy menekülése valamilyen módon korlátozott (Bourgoin 1997). Erre szolgál például néhány epigéikus sarkantyúskabóca-faj (Delphacidae), amelyek számára a hangyák „menedékhelyet” készítenek (pl. Dejean és mtsai. 1996), valamint a recéskabócák nimfái, amelyek közül egyesek jellemzően hangyák földalatti fészkében fordulnak elő (pl. Mitjaev 1967; Thompson 1984). Bizonyos esetekben még a Tettigometridae család tagjaira jellemző morfológiai adaptációk hiánya ellenére is fennállhat szoros kapcsolat a hangyagazdával, mint azt pl. a Bythopsyrna circulata lepkeszárnyú kabóca (Flatidae) és a Camponotus gigas asszociációja mutatja (Pfeiffer és Linsenmair 2007). Egy további speciális esetet képviselnek azok a bordásfejü kabóca (Fulgoridae) fajok, amelyek sajátos morfológiai változások (pl. a szemek, ill. szárnyak redukciója, csökkent pigmentáció, érzékszőrök 
megjelenése, stb.) révén alkalmazkodtak a földalatti vagy barlangi életmódhoz (China és Fennah 1952; Hoch 1990; Fletcher és Moir 2009), mely troglomorfiának nevezett folyamatot egyes elképzelések szerint a hangyákkal való együttélés is elősegíthette (Hoch és mtsai. 2006).

Bourgoin (1997) szerint a Fulgoromorpha alrenden belül összesen négy fő típusa különböztethető meg a hangya-kabóca interakcióknak: (1) a hangyák a különböző szubsztrátumra (pl. levelekre, talajra, stb.) lehullott mézharmatot gyüjtik be; (2) a kabócák a hangyák földalatti fészkeiben élnek; (3) a kabócák a talajfelszín feletti, hangyák által készített „menedékhelyeken” fordulnak elő; (4) a hangyák rendszeresen látogatják a kabócákat, amelyekkel közvetlen kontaktusba lépve gyüjtik be az általuk kibocsátott mézharmatot. A korábban dokumentált hangya-recéskabóca interakciók jelentős többségéhez hasonlóan az A. subterranea és a $R$. panzeri nimfáinak asszociációja is a második típusba sorolható be, bár továbbra is kérdés marad, hogy ez pusztán egyszerü együttélést vagy tényleges mutualista kapcsolatot jelent-e közöttük. Jelenleg mindössze az Anoplolepis gracilipes és a Fipsianus picturatus páros esetében ismert valódi trofobiotikus kapcsolat hangya és recéskabóca között, bár itt sem a talajlakó kabócanimfák, hanem a már kifejlett, arboreális életmódú egyedek részvételével (Holzinger 2009).

Vizsgálataim alapján az $A$. subterraneának a $R$. panzeri nimfáival való kapcsolata feltehetőleg fakultatív jellegü, lévén ezen hangyafaj fészkeinek mindössze felében sikerült csak kabócanimfákat, ill. ezek korábbi jelenlétére utaló nyomokat találni. A $R$. panzeri részéről ugyanakkor a kapcsolat már inkább obligát jellegünek tűnik, minthogy egyrészt a nimfák jelentős többsége hangyafészkekből került elő, másrészt pedig a fészken kívül talált nimfák is a legtöbb esetben az A. subterranea dolgozóival együtt voltak megfigyelhetőek. Bár nem támasztja alá közvetlen bizonyíték, hogy a nimfák a hangyafészkekben telelnének át, eredményeim mindestre azt valószínűsítik, hogy a $R$. panzeri egyedei a korai stádiumú nimfaállapotuktól egészen imágókorukig együtt élnek a gazdakolóniákkal. A hangyákkal való asszociáció a kabóca részéről ráadásul kifejezetten monospecifikusnak tűnik, minthogy a nimfák majdnem kizárólag az A. subterranea fészkeiben voltak csak megtalálhatóak. Ez ellentétben áll azon tanulmányokkal, amelyek szerint a kabócák hangyákkal való interakciója rendszerint fakultatív jellegü, függetlenül attól, hogy milyen magas fokon álló kapcsolat alakult ki közöttük (Steiner és mtsai. 2004; Pfeiffer és Linsenmair 2007; Maravalhas és Morais 2009). Még ha a hangyák erőteljesebben is függnek kabócapartnereiktől, utóbbiak még ebben az esetben is rendszerint több hangyafajjal együtt fordulnak elő (Dejean és mtsai. 2000; Moya-Raygoza és Nault 2000; Lehouck és mtsai. 2004). 
Természetesen felmerülhet a kérdés, hogy a $R$. panzeri nimfáinak csaknem kizárólagos preferenciája az A. subterranea mint hangyagazda felé nem csupán annak következménye-e, hogy ez utóbbi bizonyult a legabundánsabb hangyafajnak a vizsgálat során. Ennek azonban ellentmond az a tény, miszerint a $P$. nitens abundanciája a korábbi fészektérképezések alapján összességében legalább olyan nagynak (ha nem nagyobbnak) mondható ezen az élőhelyen, mint az A. subterraneáé, ennek ellenére az előbbi faj fészkeiből jelen vizsgálat során is mindössze két alkalommal sikerült csak nimfákat kimutatni, amelyekből az egyik esetben ráadásul a nimfákkal együtt néhány A. subterranea dolgozó is megfigyelhető volt. Emellett, a R. panzeri nimfái jelen vizsgálat óta a litéri fenyvesben is több alkalommal elökerültek már (ld. 29. ábra), ugyancsak kizárólag az A. subterranea fészkeiből (Lőrinczi, szem. megfigy.), ami arra utal, hogy a két faj közötti szoros asszociáció még csak nem is korlátozódik feltétlenül egyetlen élőhelyre. A Cixiidae családon belül mindezidáig egyedül ÉszakAmerikában, a Nylanderia arenivaga és az Oecleus borealis nimfái között írtak le hasonló szoros asszociációt hangya és recéskabóca között (Thompson 1984). Thompson (1984) szerint az $O$. borealis nimfáinak nyeresége ezen kapcsolatból, hogy a hangyák fészekkonstrukciós tevékenységei révén jobban hozzáférhetnek tápnövényeik gyökeréhez a fészken belül, míg a hangyáké a nimfák által termelt mézharmat mint táplálékforrás, noha a kapcsolat trofobiotikus jellegét itt sem nem sikerült egyértelmüen igazolni.

Annak ellenére, hogy a vizsgálatok során sem mézharmatgyüjtés, sem más egyéb direkt kontaktus nem volt megfigyelhető az A. subterranea dolgozói és a $R$. panzeri nimfái között, mégis eléggé valószínünek tủnik, hogy a kapcsolat közöttük mutualista jellegü, lévén (1) a hangyadolgozók nem mutattak zsákmányszerző vagy agonisztikus viselkedést a kabócanimfákkal szemben; (2) a nimfák, noha képesek védekezésképpen elugrani, egy esetben sem próbáltak elmenekülni a hangyák elől; (3) a hangyafészkeken kívül talált nimfák rendszeresen az A. subterranea dolgozóival együtt fordultak elő, egy alkalommal még akkor is, amikor a nimfák egy másik hangyafaj fészkében voltak jelen. Mindezek alapján tehát könnyen elképzelhető, hogy a $R$. panzeri nimfái nem csupán megtürt „társbérlők” az A. subterranea fészkeiben, ahol amellett, hogy védelmet élveznek természetes ellenségeiktől, a tápnövényeik gyökereihez is jobban hozzáférnek, hanem valódi trofobionta partnerei a hangyagazdájuknak, ahogyan az oly sok más hangya-hemiptera kapcsolat esetében is jellemző (Buckley 1987; Hölldobler és Wilson 1990; Delabie 2001; Stadler és Dixon 2005). 


\section{6. Összefoglaló}

A kompetíciót hagyományosan az egyik legfontosabb közösségszervező mechanizmusként tartják számon a hangyáknál, amelyre a dominancia hierarchiák meglététől kezdve a territorialitáson és ennek különböző megjelenési formáin át a dominancia és diverzitás kapcsolatáig számos bizonyíték szolgál. Az egymással versengő fajok tartós együttélését, és így a lokális diverzitás fenntartását ugyanakkor számos kompenzáló mechanizmus segítheti elö, amelyek közül leginkább a különböző csereviszonyok, ill. a készletek tér- és/vagy időbeli felosztása tünik a leginkább meghatározónak, de emellett a kompetitív interakciók kimenetelét befolyásoló más egyéb tényezők szerepe is ugyancsak fontos lehet.

A jelen dolgozatban bemutatott vizsgálatok fö célja két szubmediterrán erdei hangyaközösség összetételének, ill. tér- és időbeli szerveződésének feltárása volt, amelyet nagyrészt fészektérképezések és csalétkes kísérletek segítségével végeztem. Alaphipotézisem szerint a különböző készletekért (fészkelőhelyekért és/vagy táplálékért) folyó kompetíció meghatározó a vizsgált közösségek szerveződésében, amely többek között (1) a fészkek szegregált diszpergáltságában, ill. térbeli eloszlásuk egyenletességének fokozatos növekedésében, (2) a fészkek términtázatának denzitástól való függésében, (3) a különböző, készlethasználattal, ill. hőmérsékleti toleranciával kapcsolatban álló csereviszonyok meglétében, (4) az egyes fajok táplálékkereső dolgozóinak tér- és/vagy időbeli (napi és/vagy szezonális) elkülönülésében, valamint (5) a lineáris (tranzitív) dominancia hierarchiák kialakulásában fog megmutatkozni.

Vizsgálataim eredményei alapján a legabundánsabb és leggyakoribb fajok a füredi tölgyesben a Prenolepis nitens és az Aphaenogaster subterranea, míg a litéri fenyvesben az A. subterranea, Lasius emarginatus és a Formica fusca voltak.

Az előzetes hipotézisekkel szemben a két élőhelyen (1) az egyes, abundánsabb fajok fészkei intraspecifikusan többnyire véletlenszerü diszpergáltságot mutattak, és a legtöbb esetben hasonlóképpen véletlenszerünek bizonyult az egyes kvadrátokban regisztrált összes fészek términtázata is; (2) egyetlen esetet leszámítva a fészkek denzitása és diszpergáltsága között nem volt kimutatható szignifikáns pozitív összefüggés; (3) a fészkek térbeli eloszlásának egyenletessége nem növekedett az évad során, sőt, a fészektérmintázat vagy alapvetően nem is változott jelentősen (litéri fenyves), vagy éppen szegregáltból ment át véletlenszerübe (füredi tölgyes). Összességében interspecifikusan többnyire a fészkek erőteljes aggregációja volt jellemző, és ezzel együtt a legközelebbi heterospecifikus szomszéd 
távolságok is rendre szignifikánsan kisebbnek bizonyultak a legközelebbi konspecifikus szomszéd távolságoknál.

A legközelebbi fészekszomszéd távolságok mindkét élőhelyen többnyire jelentős ingadozást mutattak az évad során, amely, bár az egyes, abundánsabb fajok esetében viszonylag egyedi módon és mértékben mutatkozott meg, rendszerint a fészekszomszéd távolságok megnövekedését jelentette, szoros összefüggésben a fészkek tavasztól őszig való denzitáscsökkenésével. Két faj, a P. nitens és a L. emarginatus esetében azonban ettől jelentős mértékben eltérö trend volt megfigyelhető; míg előbbinél a fészkek denzitása tavasszal, ill. nyár végén és ősszel volt a legnagyobb, addig utóbbinál a nyár elején érte el maximumát. Minthogy mindkét faj csalétkeken mutatott aktivitása is ugyanezen periódusokban volt a legnagyobb, a szezonális expanzió legvalószínủbb oka az lehet, hogy ezen fajok kolóniái az év bizonyos szakában több, különálló fészket elfoglaló alegységre fragmentálódnak, vagy ezen időszakokban a dolgozók több fészekkijáratot is megnyitnak, ezáltal növelve meg a kolónia táplálkozási területét, ill. csökkentve le a keresési időt és a dolgozók által a táplálékforrás és a fészek között megtett távolságokat.

A fészkek többnyire véletlenszerü térbeli eloszlását, ill. a denzitásfüggő diszpergáltság hiányát magyarázhatja, hogy (1) ezeken az élőhelyeken az alkalmas fészkelöhelyek nem jelentenek limitáló tényezőt, így ezek abundanciája és diszpergáltsága határozza meg a fészkek términtázatát; (2) a kolóniák mortalitása nem denzitástól függő, hanem térben random, amely véletlenszerü diszpergáltságot eredményez függetlenül attól, hogy a fészkek términtázata eredetileg milyen volt; (3) a különböző környezeti tényezők közvetlenül vagy közvetetten, a különböző denzitásfüggő folyamatokon keresztül hatva befolyásolják a fészektérmintázat jellegét; (4) a kolóniák bizonyos időközönkénti relokációja a szezonális polidómiával együtt nagyfokú instabilitás ad a fészkek términtázatának, amelynek relatíve gyors ütemű változása meggátolja a kolóniák közötti szorosabb kölcsönhatások kialakulását.

A csalétkes kísérletek során a felállított hipotézisekkel szemben (1) sem a dominanciaforrásfelfedezés trade-off, sem a dominancia-hőmérsékleti tolerancia trade-off meglétét nem sikerült igazolni, és emellett (2) a csalétkeket látogató gyakoribb fajok napi aktivitásában sem volt kimutatható jelentős elkülönülés.

Az évszakos elkülönülés leginkább a füredi tölgyesben látszott meghatározónak, ahol az élőhely két ökológiailag domináns faja, az A. subterranea és a $P$. nitens szezonális aktivitásában a vártnál jelentősen kisebb mértékű átfedés volt kimutatható. Míg előbbi szezonális aktivitásának csúcsát a nyár elején érte el, addig utóbbi a hűvösebb tavaszi és őszi időszakban bizonyult a legaktívabbnak. A $P$. nitens aktivitását ráadásul más szüntopikus 
fajoktól eltérően télen is megőrizte, amikor is dolgozói még a fagyponthoz közeli hőmérsékleteken is aktívan kijártak táplálékot keresni.

A térbeli elkülönülés jelentőségét látszott igazolni mindkét élőhelyen, hogy (1) a csalétkeken regisztrált fajok jelentős mértékben különböztek a tekintetben, hogy a talajon vagy fákon elhelyezett csalétkeket látogatták-e nagyobb arányban, valamint (2) számos gyakoribb fajpáros esetében a csalétkeken való együttes elöfordulás mértéke a vártnál szignifikánsan kisebb volt azokra az időszakokra nézve, amikor az illető fajpáros mindkét tagja viszonylag nagyobb aktivitást mutatott.

Annak ellenére, hogy a dominancia rangsorrendje alapján a domináns és szubordinált fajok mindkét élőhelyen viszonylag jól elkülönültek egymástól, a dominancia-hierarchia linearitása egyik esetben sem különbözött szignifikánsan a véletlenszerütől, amely alighanem a nem ismert dominanciaviszonyok viszonylag nagy számának tudható be, lévén bizonyos fajpárok tagjai az erős térbeli szegregáció és/vagy a kevésbé gyakori előfordulásuk miatt nem konfrontálódtak a csalétkeken.

A legtöbb agresszív megnyilvánulás és csalétekről való kizárás mindkét élőhelyen az A. subterraneához volt köthetö. A faj ezeken az élőhelyeken mutatott nagyfokú viselkedésbeli dominanciájára (1) nagy lokális abundanciája, ill. gyakori előfordulása (azaz számbeli dominanciája), (2) a hasonló viselkedésbeli dominanciát mutató fajoktól (pl. P. nitens, L. emarginatus) való tér- és/vagy időbeli (szezonális) elkülönülése, valamint (3) az agresszív, territoriális fajok (füredi tölgyes: Liometopum microcephalum, Crematogaster schmidti; litéri fenyves: Formica pratensis) csekély mértékü jelenléte és/vagy hatása szolgálhat magyarázatul. A faj általános sikeréhez a fentiek mellett nagyban hozzájárulhat sajátos eszközhasználó viselkedése, amelynek során dolgozói a folyékony táplálék elszállításához különböző, a környezetükben fellelhető anyagokat (pl. talajszemcséket, levéldarabokat, stb.) használnak fel úgy, hogy azokat a folyadék felszínére hordják, majd az így impregnált „eszközöket” szállítják vissza a fészkükbe. Az eszközhasználat ezen formájának fő adaptációs elönye (1) a táplálékforrás hathatósabb védelme, (2) a folyékony táplálék hatékonyabb szállítása, valamint (3) a más fajokkal való ütközés elkerülésének lehetősége. Szintén potenciálisan a faj ökológiai dominanciájához járulhat hozzá a Reptalus panzeri recéskabócafajjal való szoros asszociációja is, amely, bár csupán közvetett bizonyítékok támasztják alá, az egyszerü együttélésen túl tényleges mutualista kapcsolatot is jelenthet a két faj között, ezáltal stabil mézharmatforrást és az ezzel járó előnyöket biztosítva az A. subterranea kolóniái számára ezeken az élőhelyeken. 


\section{Summary}

Competition is traditionally considered to be one of the most important mechanisms affecting community organization in ants. Evidence for competition is provided by a number of findings, from dominance hierarchies through territoriality and its various expressions to dominance-diversity relationships. The stable coexistence of competing species, and thus the maintenance of local diversity, however, can be promoted by many compensatory mechanisms. Among these, the role of various trade-offs together with spatial and temporal resource partitioning seems to be the most relevant, but factors that influence the outcomes of competitive interactions can also be important.

The main objective of the research presented in this thesis was to explore the composition and spatiotemporal organization of two sub-Mediterranean woodland ant communities. This was performed primarily by using nest mapping and baiting experiments. According to my overall hypothesis, competition for different resources (nesting sites and/or food) plays an important role in the organization of the communities examined, resulting in, inter alia, (1) the regular spatial distribution of ant nests and the increase of regularity in their spacing in time, (2) the density-dependence of nest spacing patterns, (3) the significance of trade-offs in resource use and thermal tolerance, (4) the spatial and/or temporal (daily and/or seasonal) segregation of foraging workers of different species, and (5) the occurrence of linear (transitive) dominance hierarchies.

Based on my results, the most abundant and frequent species were Prenolepis nitens and Aphaenogaster subterranea in the oak forest (Balatonfüred), and A. subterranea, Lasius emarginatus and Formica fusca in the pine forest (Litér).

Contrary to my hypotheses, (1) the nests of the most abundant species were mostly randomly distributed intraspecifically, and all nests mapped inside each plot also showed a random spatial distribution in most cases; (2) except for a single case, no significant positive correlation was found between nest density and the degree of spatial regularity; (3) the spatial regularity of nests did not increase during the season, in fact, the distribution pattern of nests did not change significantly (pine forest), or changed from regular to random (oak forest). Overall, the nests were mostly strongly aggregated interspecifically, and the nearest heterospecific neighbour distances proved to be significantly shorter in most cases than the nearest conspecific neighbour distances.

Generally, the nearest inter-nest distances showed significant variations during the season in both habitats. Although this variation was revealed in a relatively varying manner 
and measure in the case of individual species, it was usually expressed as the increase of nearest inter-nest distances, in close connection with the decreasing of nest density from spring to autumn. In the case of two species, P. nitens and L. emarginatus, however, a completely different trend was observed. In the case of the former species, nest density was highest in spring and in late summer and autumn, while in the case of the latter, nest density reached its maximum in early summer. Considering that the foraging activity of both species was the highest in the same periods as well, the most likely reason for the seasonal expansion may be that the colonies of these species split into several subunits occupying separate nests in certain periods of the year, or workers open up more nest entrances in these periods. These may contribute to the extension of the foraging area of colonies, and to the decrease of search time and distances traveled by foragers between the food source and the nest.

The mostly random spatial distribution of nests, and the lack of density-dependent spacing can be explained by the following considerations: (1) suitable nesting sites may not be a limiting factor in these habitats, so the abundance and dispersion of these determine the distribution pattern of nests; (2) the mortality of colonies may not be density-dependent but spatially random, resulting in random patterns of spatial distribution whether the original pattern was aggregated, random or regular; (3) various environmental factors may influence the distribution pattern of nests either directly or indirectly through density-dependent processes; (4) the seasonal relocation of colonies together with seasonal polydomy may give instability to nest spacing patterns, whose relatively rapid change prevent the formation of strong interactions between neighbouring colonies.

Contrary to the proposed hypotheses, (1) no evidence was found for either the dominance-discovery trade-off or the dominance-thermal tolerance trade-off during baiting trials, and (2) there was no significant segregation in diurnal activity patterns of species that commonly visited the baits.

Seasonal segregation seemed to be important in the oak forest, where the seasonal overlap between the two locally ecologically dominant species, A. subterranea and $P$. nitens, was significantly less than expected by chance. While the former species reached its seasonal activity peak in early summer, the latter proved to be most active in the cooler periods of the year, in spring and autumn. Besides, contrary to other syntopic species, P. nitens remained active all winter, while its workers were actively foraging above-ground even near freezing.

Spatial segregation seemed to be supported in both habitats by the following observations: (1) species recorded at baits differed significantly on whether they visited baits placed on the ground or on tree trunks more frequently; (2) in the case of a number of species 
pairs, co-occurrence at baits was significantly less frequent than expected by chance for those periods when both members of these pairs showed relatively higher seasonal activity.

Contrary to the fact that dominant and subordinate species could be well differentiated from each other in both habitats based on dominance rank orders, the linearity of dominance hierarchies did not represent a significant departure from chance. This is probably due to the high number of unknown dominance relationships, given that members of some species pairs, owing to their strong spatial segregation and/or less frequent occurrence, never confronted each other at baits.

The most aggressive reactions and exclusions from baits were clearly demonstrated by A. subterranea in both habitats. The high behavioural dominance of this species in these habitats can be explained by (1) its high local abundance and frequent occurrence (i.e., high numerical dominance), (2) its spatial and/or temporal (seasonal) segregation from other species with a similar degree of behavioural dominance (e.g., P. nitens, L. emarginatus), and (3) the slight presence and/or impact of aggressive, territorial species (oak forest: Liometopum microcephalum, Crematogaster schmidti; pine forest: Formica pratensis). The overall success of A. subterranea may also be further augmented by its unique tool-using behaviour, during which foragers use different solid materials found in their environment (e.g., pieces of soil, fragments of leaves, etc.) to transport liquid food. They perform this by dropping debris into the food, and then carrying these food-soaked "tools" back to the nest. The main adaptive advantages of this tool-using behaviour are (1) the more effective protection of the food source, (2) the more efficient transport of liquid food, and (3) a better chance of avoiding interference with other ant species. In addition, the close association with the cixiid planthopper species, Reptalus panzeri can also potentially contribute to the ecological dominance of this ant species. This association, although only supported by circumstantial evidences, may represent a true mutualistic relationship between the two species beyond simple cohabitation, thereby providing a constant source of honeydew and benefits going along with it for colonies of A. subterranea in these habitats. 


\section{Irodalomjegyzék}

ADAMS E. S. (1990): Boundary disputes in the territorial ant Azteca trigona: effects of asymmetries in colony size. Animal Behaviour 39, 321-328.

ADAMS E. S. (1994): Territory defense by the ant Azteca trigona: maintenance of an arboreal ant mosaic. Oecologia 97, 202-208.

ADAMS E. S. \& TSCHINKEL W. R. (1995): Spatial dynamics of colony interactions in young populations of the fire ant Solenopsis invicta. Oecologia 102, 156-163.

AgBogba C. (1985): Observations sur la récolte de substances liquids et de sucs animaux chez deux espèces d'Aphaenogaster: A. senilis et A. subterranea (Hym. Formicidae). Insectes Sociaux 32, 427-434.

Albrecht M. \& Gotelli N. J. (2001): Spatial and temporal niche partitioning in grassland ants. Oecologia 126, 134-141.

Albuquerque E. Z. DE, DieHL-Fleig E., Diehl E. (2005): Density and distribution of nests of Mycetophylax simplex (Emery) (Hymenoptera, Formicidae) in areas with mobile dunes on the northern coast of Rio Grande do Sul, Brazil. Revista Brasileira de Entomologia 49, 123-126.

ANDERSEN A. N. (1991): Parallels between ants and plants: implications for community ecology. In: Huxley C. R. \& CuTLeR D. F. (eds.): Ant-plant interactions. Oxford University Press, Oxford, UK, pp. 539-558.

ANDERSEN A. N. (1992): Regulation of "momentary" diversity by dominant species in exceptionally rich ant communities of the Australian seasonal tropics. American Naturalist 140, 401-420.

ANDERSEN A. N. (1995): A classification of Australian ant communities based on functional groups which parallel plant life-forms in relation to stress and disturbance. Journal of Biogeography 22, 15-29.

ANDERSEN A. N. (1997): Functional groups and patterns of organization in North American ant communities: a comparison with Australia. Journal of Biogeography 24, 433-460.

ANDERSEN A. N. (2008): Not enough niches: non-equilibrial processes promoting species coexistence in diverse ant communities. Austral Ecology 33, 211-220.

ANDERSEN A. N. (2010): Functional groups in ant community ecology. In: LACH L., PARR C. L., Аввотт K. L. (eds.): Ant ecology. Oxford University Press, Oxford, UK, pp. 142-144. 
Andersen A. N. \& PAtel A. D. (1994): Meat ants as dominant members of Australian ant communities: an experimental test of their influence on the foraging success and forager abundance of other species. Oecologia 98, 15-24.

ANDRÁSFAlvy A. (1961): Mitteilungen über die Daten des Hochzeitsfluges verschiedener Ameisenarten in Ungarn und Ergebnisse von Versuchen der Koloniegründung im Formicar bei diesen Arten. Insectes Sociaux 8, 299-310.

ARnAn X., Gaucherel C., ANdersen A. N. (2011): Dominance and species co-occurrence in highly diverse ant communities: a test of the interstitial hypothesis and discovery of a competition cascade. Oecologia 166, 783-794.

BACH C. E. (1991): Direct and indirect interactions between ants (Pheidole megacephala), scales (Coccus viridis) and plants (Pluchea indica). Oecologia 87, 233-239.

Banschbach V. S., Brunelle A., Bartlett K. M., Grivetti J. Y., Yeamans R. L. (2006): Tool use by the forest ant Aphaenogaster rudis: ecology and task allocation. Insectes Sociaux 53, 463-471.

Barber J. T., Ellgaard E. G., Thien L. B., Stack A. E. (1989): The use of tools for food transportation by the imported fire ant, Solenopsis invicta. Animal Behaviour 38, $550-552$.

BARTON K. E., SANDERS N. J., GORDON D. M. (2002): The effects of proximity and colony age on interspecific interference competition between the desert ants Pogonomyrmex barbatus and Aphaenogaster cockerelli. American Midland Naturalist 148, 376-382.

BEN-Dov Y. \& FISHER B. L. (2010): The mutualism of Melissotarsus ants and armoured scale insects in Africa and Madagascar: distribution, host plants and biology. Entomologia Hellenica 19, 45-53.

Bentley-Condit V. K. \& SMith E. O. (2009): Animal tool-use: current definitions and an updated comprehensive catalog. Behaviour 147, 185-221.

BERNSTEIN R. A. (1979): Schedules of foraging activity in species of ants. Journal of Animal Ecology 48, 921-930.

BERNSTEIN R. A. \& GobBel M. (1979): Partitioning of space in communities of ants. Journal of Animal Ecology 48, 931-942.

Bertin S., Picciau L., Ács Z., Alma A., Bosco D. (2010): Molecular differentiation of four Reptalus species (Hemiptera: Cixiidae). Bulletin of Entomological Research 100, 551-558. 
Bestelmeyer B. T. (1997): Stress tolerance in some Chacoan dolichoderine ants: implications for community organization and distribution. Journal of Arid Environments 35, 297-310.

Bestelmeyer B. T. (2000): The trade-off between thermal tolerance and behavioural dominance in a subtropical South American ant community. Journal of Animal Ecology 69, 998-1009.

Bestelmeyer B. T., Agosti D., Alonso L. E., Brandẽo C. R. F., Brown W. L. JR., Delabie J. H. C., Silvestre R. (2000): Field techniques for the study of ground-dwelling ants: an overview, description and evaluation. In: Agosti D., Majer J. D., Alonso L. E., SCHULTZ T. R. (eds.): Ants: standard methods for measuring and monitoring biodiversity. Smithsonian Institution Press, Washington, D.C., USA, pp. 122-144.

Bialas B., Granieczny P., PęDzisz A., Mitrus S. (2011): Colony size, density and type of nesting sites of the ant Temnothorax crassispinus (Hymenoptera: Formicidae). Nature Journal (Opole Scientific Society) 44, 185-191.

BILLICK I. \& TONKEL K. (2003): The relative importance of spatial vs. temporal variability in generating a conditional mutualism. Ecology 84, 289-295.

Blüthgen N., Verhaagh M., Goitía W., Jaffé K., Morawetz W., Barthlott W. (2000): How plants shape the ant community in the Amazonian rainforest canopy: the key role of extrafloral nectaries and homopteran honeydew. Oecologia 125, 229-240.

BlÜthgen N., Stork N. E., Fiedler K. (2004): Bottom-up control and co-occurrence in complex communities: honeydew and nectar determine a rainforest ant mosaic. Oikos 106, 344-358.

Bolton B. (2014): AntCat: an online catalog of the ants of the world. Available from http://antcat.org/.

BorHIDI A. (2003): Magyarország növénytársulásai. Akadémiai Kiadó, Budapest, 610 pp.

BourgoIn T. (1997): Habitat and ant-attendance in Hemiptera: a phylogenetic test with emphasis on trophobiosis in Fulgoromorpha. In: GRANDCOLAS P. (ed.): The origin of biodiversity in insects: phylogenetic tests of evolutionary scenarios. Mémoires du Muséum national d'Historie naturelle 173, Paris, pp. 109-124.

Bregant E. (1998): Zur Biologie und Verbreitung der Honigameise Prenolepis nitens (Mayr, 1852) in Österreich (Hymenoptera: Formicidae). Myrmecologische Nachrichten 2 , 14-18.

Brown M. J. F. (1999): Nest relocation and encounters between colonies of the seedharvesting ant Messor andrei. Insectes Sociaux 46, 66-70. 
BUCKLEY R. C. (1987): Interactions involving plants, homoptera, and ants. Annual Review of Ecology and Systematics 8, 111-135.

Buschinger A. (1973): Transport und Ansetzen von Larven an Beutestücke bei der Ameise Aphaenogaster subterranea (Latr.) (Hym., Formicidae). Zoologischer Anzeiger 190, 63-66.

Castracani C., Grasso D. A., Fanfani A., Mori A. (2010): The ant fauna of Castelporziano Presidential Reserve (Rome, Italy) as a model for the analysis of ant community structure in relation to environmental variation in Mediterranean ecosystems. Journal of Insect Conservation 14, 585-594.

Cerdá X., Bosch J., Alsina A., Retana J. (1988): Dietary spectrum and activity pattern of Aphaenogaster senilis (Hymenoptera: Formicidae). Annales de la Société Entomologique de France 24, 69-75.

Cerdá X., Retana J., Cros S. (1997): Thermal disruption of transitive hierarchies in Mediterranean ant communities. Journal of Animal Ecology 66, 363-374.

Cerdá X., Retana J., Manzaneda A. (1998a): The role of competition by dominants and temperature in the foraging of subordinate species in Mediterranean ant communities. Oecologia 117, 404-412.

CERdÁ X., RetAnA J., CROS S. (1998b): Critical thermal limits in Mediterranean ant species: trade-off between mortality risk and foraging performance. Functional Ecology 12, 45-55.

Cerdá X., Retana J., Cros S. (1998c): Prey size reverses the outcome of interference interactions of scavenger ants. Oikos 82, 99-110.

Cerdé X., Dahbi A., Retana J. (2002): Spatial patterns, temporal variability, and the role of multi-nest colonies in a monogynous Spanish desert ant. Ecological Entomology 27, $7-15$.

Cerdá X., Angulo E., Caut S., Courchamp F. (2012): Ant community structure on a small Pacific island: only one native species living with the invaders. Biological Invasions 14, 323-339.

Cerdá X., Arnan X., Retana J. (2013): Is competition a significant hallmark of ant (Hymenoptera: Formicidae) ecology? Myrmecological News 18, 131-147.

China W. E. \& Fennah R. G. (1952): A remarkable new genus and species of Fulgoroidea (Homoptera) representing a new family. Annals and Magazine of Natural History 12, 189-199. 
Christian K. A. \& Morton S. R. (1992): Extreme thermophilia in a central Australian ant, Melophorus bagoti. Physiological Zoology 65, 885-905.

Clark P. J. \& Evans F. C. (1954): Distance to nearest neighbor as a measure of spatial relationships in populations. Ecology 35, 445-453.

Cole B. J., Haight K., WiERnasz D. C. (2001): Distribution of Myrmecocystus mexicanus (Hymenoptera: Formicidae): association with Pogonomyrmex occidentalis (Hymenoptera: Formicidae). Annals of the Entomological Society of America 94, 59-63.

Collingwood C. A. (1979): The Formicidae (Hymenoptera) of Fennoscandia and Denmark. Fauna Entomologica Scandinavica 8, 1-174.

CRIST T. O. \& WIENS J. A. (1996): The distribution of ant colonies in a semiarid landscape: implications for community and ecosystem processes. Oikos 76, 301-311.

Cros S., Cerdá X., Retana J. (1997): Spatial and temporal variations in the activity patterns of Mediterranean ant communities. Écoscience 4, 269-278.

Csősz S., Markó B., Kiss K., TARTally A., Gallé L. (2002): The ant fauna of the FertöHanság National Park. In: MAHUnKa S. (ed.): The fauna of the Fertö-Hanság National Park. Akadémiai Kiadó, Budapest, pp. 617-629.

CUSHMAN J. H. (1991): Host-plant mediation of insect mutualisms: variable outcomes in herbivore-ant interactions. Oikos 61, 138-144.

Cushman J. H., Martinsen G. D., Mazeroll A. I. (1988): Density- and size-dependent spacing of ant nests: evidence for intraspecific competition. Oecologia 77, 522-525.

Cushman J. H. \& Whitham T. G. (1989): Conditional mutualism in a membracid-ant association: temporal, age-specific, and density-dependent effects. Ecology 70, 1040-1047.

Czechowski W., RAdChenko A., Czechowska W. (2002): The ants (Hymenoptera, Formicidae) of Poland. MIZ PAS, Warszawa, 200 pp.

Czechowski W. \& MARKó B. (2005): Competition between Formica cinerea Mayr (Hymenoptera: Formicidae) and co-occurring ant species, with special reference to Formica rufa L.: direct and indirect interferences. Polish Journal of Ecology 53, 467-487.

CZEChOWsKi W., RAdChENKo A., CZECHOWSKA W., VePsÄLÄINEN K. (2012): The ants (Hymenoptera, Formicidae) of Poland with reference to the myrmecofauna of Europe. MIZ PAS, Warszawa, 496 pp. 
CZEChOWsKi W., MARKó B., RADCHENKo A., ŚLIPIŃSKi P. (2013): Long-term partitioning of space between two territorial species of ants (Hymenoptera: Formicidae) and their effect on subordinate species. European Journal of Entomology 110, 327-337.

DAVIDSON D. W. (1998): Resource discovery versus resource domination in ants: a functional mechanism for breaking the trade-off. Ecological Entomology 23, 484-490.

Davidson D. W., Cook S. C., Snelling R. R., Chua T. H. (2003): Explaining the abundance of ants in lowland tropical rainforest canopies. Science 300, 969-972.

Davidson D. W., CoOK S. C., SNElling R. (2004): Liquid-feeding performances of ants (Formicidae): ecological and evolutionary implications. Oecologia 139, 255-266.

Debout G., Schatz B., Elias M., MCKey D. (2007): Polydomy in ants: what we know, what we think we know, and what remains to be done. Biological Journal of the Linnean Society 90, 319-348.

DEBRECZY Zs. (1973): A Balaton-felvidéki Péter-hegy és környéke cönológiai vizsgálata. Veszprém Megyei Múzeumok Közleményei 12, 191-220.

Dejean A., Ngnegueu P. R., Bourgoin T. (1996): Trophobiosis between ants and Peregrinus maidis (Hemiptera, Fulgoromorpha, Delphacidae). Sociobiology 28, 111-120.

Dejean A., Bourgoin T., Gibernau M. (1997): Ant species that protect figs against other ants: result of territoriality induced by a mutualistic homopteran. Écoscience 4, 446-453.

DeJEAn A. \& Bourgoin T. (1998): Relationships between ants (Hymenoptera: Formicidae) and Euphyonarthex phyllostoma (Hemiptera: Tettigometridae). Sociobiology 32, 91100.

Dejean A., Bourgoin T., Orivel J. (2000): Ant defense of Euphyonarthex phyllostoma (Homoptera: Tettigometridae) during trophobiotic associations. Biotropica 32, 112-119.

Dekoninck W., De Koninck H., Baugnée J.-Y., Maelfait J.-P. (2007): Ant biodiversity conservation in Belgian calcareous grasslands: active management is vital. Belgian Journal of Zoology 137, 137-146.

DelabIE J. H. C. (2001): Trophobiosis between Formicidae and Hemiptera (Sternorrhyncha and Auchenorrhyncha): an overview. Neotropical Entomology 30, 501-516.

Delabie J. H. C., Agosti D., Nascimento I. C. (2000): Litter ant communities of the Brazilian Atlantic rain forest region. In: Agosti D., MAJER J. D., Alonso L., Schultz T. (eds.): Sampling ground-dwelling ants: case studies from the world's rain forests. Curtin University School of Environmental Biology, Bulletin No. 18, Perth, Australia, pp 1-17. 
Del-Claro K. \& Oliveira P. S. (1999): Ant-Homoptera interactions in a neotropical savanna: the honeydew-producing treehopper, Guayaquila xiphias (Membracidae), and its associated ant fauna on Didymopanax vinosum (Araliaceae). Biotropica 31, 135-144.

Del-Claro K. \& Oliveira P. S. (2000): Conditional outcomes in a neotropical treehopperant association: temporal and species-specific variation in ant protection and homopteran fecundity. Oecologia 124, 156-165.

DELSINNE T., RoISIN Y., LEPONCE M. (2007): Spatial and temporal foraging overlaps in a Chacoan ground-foraging ant assemblage. Journal of Arid Environments 71, 29-44.

Dietrich C. H. \& MCKAmEY S. H. (1990): Three new idiocerine leafhopper (Homoptera: Cicadellidae) from Guyana with notes on ant-mutualism and subsociality. Proceedings of the Entomological Society of Washington 92, 214-223.

DILliER F.-X. \& WeHNER R. (2004): Spatio-temporal patterns of colony distribution in monodomous and polydomous species of North African desert ants, genus Cataglyphis. Insectes Sociaux 51, 186-196.

DONCASTER C. P. (1981): The spatial distribution of ants' nests on Ramsey Island, South Wales. Journal of Animal Ecology 50, 195-218.

Dugas D. P. (2001): The influence of arroyo edges on Pogonomyrmex rugosus nest distribution in the Chihuahuan Desert, New Mexico. Journal of Arid Environments 47, 153-159.

Dunn R. R., Agosti D., Andersen A. N., Arnan X., Bruhl C. A., Cerdá X., Ellison A. M., Fisher B. L., Fitzpatrick M. C., GibB H., Gotelli N. J., Gove A. D., Guenard B., Janda M., Kaspari M., Laurent E. J., Lessard J.-P., Longino J. T., Majer J. D., Menke S. B., McGlynn T. P., Parr C. L., Philpott S. M., Pfeiffer M., Retana J., Suarez A. V., Vasconcelos H. L., Weiser M. D., SAnders N. J. (2009): Climatic drivers of hemispheric asymmetry in global patterns of ant species richness. Ecology Letters 12, 324-333.

EISNER T. \& BROWN W. L. (1958): The evolution and social significance of the ant proventriculus. Proceedings of the Tenth International Congress of Entomology 2, 503-508.

ELMES G. W. (1974): The spatial distribution of a population of two ant species living in limestone grassland. Pedobiologia 14, 412-418.

FEENER D. H. JR. (2000): Is the assembly of ant communities mediated by parasitoids? Oikos 90, 79-88. 
FeEner D. H. JR., OrR M. R., WACKFord K. M., Longo J. M., Benson W. W., Gilbert L. E. (2008): Geographic variation in resource dominance-discovery in Brazilian ant communities. Ecology 89, 1824-1836.

Feisinger P., Spears E. E., PoOle R. W. (1981): A simple measure of niche breadth. Ecology 62, 27-32.

FELLERS J. H. (1987): Interference and exploitation in a guild of woodland ants. Ecology 68, 1466-1478.

FELLERS J. H. (1989): Daily and seasonal activity in woodland ants. Oecologia 78, 69-76.

Fellers J. H. \& Fellers G. M. (1976): Tool use in a social insect and its implications for competitive interactions. Science 192, 70-72.

FERNÁNDEZ-EsCUdERO I. \& TINAUT A. (1999): Factors determining nest distribution in the high-mountain ant Proformica longiseta (Hymenoptera Formicidae). Ethology, Ecology and Evolution 11, 325-338.

Fletcher M. J. \& MoIR M. L. (2009): Budginmaya eulae gen. et sp. nov., a myrmecophilous planthopper (Hemiptera: Fulgoromorpha: Flatidae) from Western Australia. Australian Journal of Entomology 48, 36-39.

FLOREN A. \& LinSENMAIR K. E. (2000): Do ant mosaics exist in pristine lowland rain forests? Oecologia 123, 129-137.

FolgarAit P. J. (1998): Ant biodiversity and its relationship to ecosystem functioning: a review. Biodiversity and Conservation 7, 1221-1244.

FOWLER H. G. (1982): Tool use by Aphaenogaster ants: a reconsideration of its role in competitive interactions. Bulletin of the New Jersey Academy of Sciences 27, 81-82.

Franks N. R., Dornhaus A., Hitchcock G., Guillem R., Hooper J., Webb C. (2007): Avoidance of conspecific colonies during nest choice by ants. Animal Behaviour 73, $525-534$.

FÜleky Gy., Jakab S., FehÉr O., Madarász B., Kertész Á. (2007): Hungary and the Carpathian Basin. In: Arnalds Ó., Bartoli F., BuURMAn P., OSKARSSON H., STOOPS G., GARCIA-Rodeja E. (eds.): Soils of volcanic regions in Europe. Springer-Verlag, Berlin, pp. 29-42.

GALLÉ L. (1975): Factors stabilizing the ant populations (Hymenoptera: Formicidae) in the grass associations of the Tisza Basin. Tiscia 10, 61-66.

GALLÉ L. (1979): Formicoidea populációk denzitása és produktivitása gyepcönózisokban. Kandidátusi értekezés, Szeged, 125 pp. 
GALLÉ L. (1980): Dispersion of high density ant populations in sandy soil grassland ecosystems. Acta Biologica Szeged 26, 129-135.

GALLÉ L. (1986): Habitat and niche analysis of grassland ants (Hymenoptera: Formicidae). Entomologia Generalis 11, 197-211.

GALLÉ L. (1991): Structure and succession of ant assemblages in a north European sand dune area. Holarctic Ecology 14, 31-37.

GALLÉ L. (2000): A kompetíció mint közösségformáló mechanizmus: esettanulmányok hangyákon. In: VIRÁGH K., KUN A. (eds.): Vegetáció és dinamizmus. MTA ÖBKI, Vácrátót, pp. 243-255.

GALLÉ L. (2013): A szupraindividuális biológia alapjai: populációk és közösségek biológiája. JATEPress, Szeged, 404 pp.

Gallé L., Kovács É., Hevér A. (1994): Pattern transformation of ant colonies in a successional sandy grassland. Memorabilia Zoologica 48, 81-90.

Gallé L., KÖRMÖCZI L., Hornung E., Kerekes J. (1998): Structure of ant assemblages in a Middle-European successional sand-dune area. Tiscia 31, 19-28.

Gallé L., Markó B., Kiss K., Kovács É., Dürgő H., Köváry K., Csősz S. (2005): Ant fauna of Tisza River Basin (Hymenoptera: Formicidae). In: GALlÉ L. (ed.): Vegetation and Fauna of Tisza River Basin I. Tiscia Monograph Series 7, 149-197.

Garrido J. L., Rey P. J., Cerdé X., Herrera C. M. (2002): Geographical variation in diaspore traits of an ant dispersed plant (Helleborus foetidus): are ant community composition and diaspore traits correlated? Journal of Ecology 90, 446-455.

GiBB H. (2005): The effect of a dominant ant, Iridomyrmex purpureus, on resource use by ant assemblages depends on microhabitat and resource type. Austral Ecology 30, 856-867.

GibB H. \& Hochuli D. F. (2003): Nest relocation in the golden spiny ant, Polyrhachis ammon: environmental cues and temporal castes. Insectes Sociaux 50, 323-329.

GiBB H. \& PARR C. L. (2010): How does habitat complexity affect foraging success? A test using functional measures on three continents. Oecologia 164, 1061-1073.

Gómez C., Casellas D., Oliveras J., Bas J. M. (2003): Structure of ground-foraging ant assemblages in relation to land-use change in the northwestern Mediterranean region. Biodiversity and Conservation 12, 2135-2146.

GORDON D. M. (1992): Nest relocation in harvester ants. Annals of the Entomological Society of America 85, 44-47. 
Gotelli N. J. \& ENTSMinger G. L. (2004): EcoSim: null models software for ecology. Version 7. Acquired Intelligence Inc. \& Kesey-Bear. Jericho, VT 05465. http://garyentsminger.com/ecosim/index.htm

Grimaldi D. \& ENGEL M. S. (2005): Evolution of the insects. Cambridge University Press, New York, USA, 755 pp.

HAHN D. A. \& WHEELER D. E. (2002): Seasonal foraging activity and bait preferences of ants on Barro Colorado Island, Panama. Biotropica 34, 348-356.

HalmágYi L. (1978): Adatok a Szigligeti Arborétum hangyáinak ismeretéhez. A Veszprém Megyei Múzeumok Közleményei 13, 111-112.

HAMMER Ø., HARPER D. A. T., RYAn P. D. (2001): PAST: Paleontological statistics software package for education and data analysis. Palaeontologia Electronica 4, 9 pp. http://palaeo-electronica.org/2001_1/past/issue1_01.htm

HARKNESS R. D. \& ISHAM V. (1983): A bivariate spatial point pattern of ants' nests. Applied Statistics 32, 293-303.

HARRISON J. S. \& GENTRY J. B. (1981): Foraging pattern, colony distribution, and foraging range of the Florida harvester ant, Pogonomyrmex badius. Ecology 62, 1467-1473.

HERBERS J. M. (1985): Seasonal structuring of a north temperate ant community. Insectes Sociaux 32, 224-240.

HERBERS J. M. (1989): Community structure in north temperate ants: temporal and spatial variation. Oecologia 81, 201-211.

HERBERS J. M. (2011): Nineteen years of field data on ant communities (Hymenoptera: Formicidae): what can we learn? Myrmecological News 15, 43-52.

Higashi S., Hinomizu H., Nakano S., Ohatani T., Toda M. J., Yamamoto M. (1987): Dispersion patterns of ant nests in a cool-temperate woodland of northern Japan. Research Bulletins of the College Experiment Forests 44, 603-610.

Hoch H. (1990): Cavernicolous Meenoplidae of the genus Phaconeura (Homoptera: Fulgoroidea) from Australia. Bishop Museum Occasional Papers 30, 188-203.

Hoch H., Asche M., Burwell C., Monteith G., Wessel A. (2006): Morphological alteration in response to endogeic habitat and ant association in two new planthopper species from New Caledonia (Hemiptera: Auchenorrhyncha: Fulgoromorpha: Delphacidae). Journal of Natural History 40, 1867-1886.

HoffMAN B. D. \& ANDERSEN A. N. (2003): Responses of ants to disturbance in Australia, with particular reference to functional groups. Austral Ecology 28, 444-464. 
Holway D. A. (1999) Competitive mechanisms underlying the displacement of native ants by the invasive Argentine ant. Ecology 80, 238-251.

Holway D. A., Lach L., Suarez A. V., Tsutsui N. D., Case T. J. (2002): The causes and consequences of ant invasions. Annual Review of Ecology and Systematics 33, 181-233.

HolziNGER W. E. (2009): A novel trophobiosis between ants (Hymenoptera: Formicidae) and a palm-feeding planthopper (Hemiptera: Cixiidae). African Entomology 17, 115-118.

Holzinger W. E., KAMMERLANDER I., NiCKEL H. (2003): The Auchenorrhyncha of Central Europe - Die Zikaden Mitteleuropas, Vol. 1: Fulgoromorpha, Cicadomorpha excl. Cicadellidae. Brill Publishers, Leiden, The Netherlands, 673 pp.

HÖLLDOBLER B. (1976): Recruitment behavior, home range orientation and territoriality in harvester ants. Behavioral Ecology and Sociobiology 1, 3-44.

HÖlldobler B. \& TAYLOR R. W. (1983): A behavioral study of the primitive ant Nothomyrmecia macrops. Insectes Sociaux 30, 384-401.

Hölldobler B. \& WiLson E. O. (1990): The ants. Belknap Press of Harvard University, Cambridge, Massachusetts, USA, 732 pp.

HuMAN K. G. \& GORDON D. M. (1996): Exploitation and interference competition between the invasive Argentine ant, Linepithema humile, and native ant species. Oecologia 105, 405-412.

HunT J. H. (1974): Temporal activity patterns in two competing ant species (Hymenoptera: Formicidae). Psyche 81, 237-242.

Johnson C., Agosti D., Delabie J. H., Dumpert K., Williams D. J., Tschirnhaus M. von, MASChWITZ U. (2001): Acropyga and Azteca ants (Hymenoptera: Formicidae) with scale insects (Sternorrhyncha: Coccoidea): 20 million years of intimate symbiosis. American Museum Novitates 3335, 18 pp.

Johnson N. F. (2007): Hymenoptera Name Server (version 1.5). Available from: http://osuc.biosci.ohio-state.edu/.

JOLIVET P. (1996): Ants and plants: an example of coevolution. Backhuys Publishers, Leiden, The Netherlands, $303 \mathrm{pp}$.

Jović J., Cvrković T., Mitrović M., Krnjajić S., Redinbaugh M. G., Pratt R. C., Gingery R. E., Hogenhout S. A., ToŠEvski I. (2007): Roles of stolbur phytoplasma and Reptalus panzeri (Cixiinae, Auchenorrhyncha) in the epidemiology of Maize redness in Serbia. European Journal of Plant Pathology 118, 85-89. 
Jović J., Cvrković T., Mitrović M., Krnjajić S., Petrović A., Redinbaugh M. G., Pratt R. C., Hogenhout S. A., TošEvski I. (2009): Stolbur phytoplasma transmission to maize by Reptalus panzeri and the disease cycle of Maize Redness in Serbia. Phytopathology 99, 1053-1061.

KANIZSAI O., LŐRINCZI G., GALLÉ L. (2013): Nesting associations without interdependence: a preliminary review on plesiobiosis in ants. Psyche: A Journal of Entomology 2013 (Annual Issue on Ants and Their Parasites), 9 pp.

KAY C. A. R. \& WHITFORD W. G. (1978): Critical thermal limits of desert honey ants: possible ecological implications. Physiological Zoology 51, 206-213.

Klein R.W., Kovac D., Schellerich A., Maschwitz U. (1992): Mealybug-carrying by swarming queens of a Southeast Asian bamboo-inhabiting ant. Naturwissenschaften 79, 422-423.

KNEITEL J. M. \& CHASE J. M. (2004): Trade-offs in community ecology: linking spatial scales and species coexistence. Ecology Letters 7, 69-80.

KUTTER H. (1977): Hymenoptera, Formicidae. In: Insecta Helvetica, Fauna Bd. 6. Schweizerische Entomologische Gesellschaft, Zürich, 298 pp.

LANDAU H. G. (1951): On dominance relations and the structure of animal societies: I. Effect of inherent characteristics. Bulletin of Mathematical Biophysics 13, 1-19.

LaPolla J. S., Dlussky G. M., Perrichot V. (2013): Ants and the fossil record. Annual Review of Entomology 58, 609-630.

LARSEN K. J., HEADY S. E., NAUlT L. R. (1992): Influence of ants (Hymenoptera: Formicidae) on honeydew excretion and escape behaviors in a myrmecophile, Dalbulus quinquenotatus (Homoptera: Cicadellidae), and its congeners. Journal of Insect Behavior 5, 109-122.

LEBRUn E. G. (2005): Who is the top dog in ant communities? Resources, parasitoids, and multiple competitive hierarchies. Oecologia 142, 643-652.

LEBRun E. G. \& FEENER D. H. (2007) When trade-offs interact: balance of terror enforces dominance-discovery trade-off in a local ant assemblage. Journal of Animal Ecology 76, 58-64.

LeBrun E. G., Tillberg C. V., Suarez A.V., Folgarait P. J., Smith C. R., Holway D. A. (2007): An experimental study of competition between fire ants and Argentine ants in their native range. Ecology 88, 63-75. 
Lehouck V. S., Bonte D. B., Dekoninck W., Maelfait J.-P. E. (2004): Trophobiotic relationships between ants (Hymenoptera: Formicidae) and Tettigometridae (Hemiptera: Fulgoromorpha) in the grey dunes of Belgium. European Journal of Entomology 101, 547-553.

Lessard J.-P., DunN R. R., SANDERS N. J. (2009): Temperature-mediated coexistence in temperate forest ant communities. Insectes Sociaux 56, 149-156.

Lester P. J., Stringer L. D., HAYwood J. (2010): The role of resource dispersion in promoting the co-occurrence of dominant and subordinate ant species. Oikos 119, 659-668.

LeVings S. C. \& TRAniEllo J. F. A. (1981): Territoriality, nest dispersion, and community structure in ants. Psyche 88, 265-319.

LEVINGS S. C. \& FRANKS N. R. (1982): Patterns of nest dispersion in a tropical ground ant community. Ecology 63, 338-344.

Liefke C., Dorow W. H. O., Hölldobler B., Maschwitz U. (1998): Nesting and food resources of syntopic species of the ant genus Polyrhachis (Hymenoptera, Formicidae) in West-Malaysia. Insectes Sociaux 45, 411-425.

LIN N. (1964-65): The use of sand grains by the pavement ant, Tetramorium caespitum, while attacking halictine bees. Bulletin of the Brooklyn Entomological Society 59-60, 30-34.

LŐRINCZI G. (2008): Hangyaközösségek (Hymenoptera: Formicidae) fajösszetétele és diverzitása Litér környéki szubmediterrán élőhelyeken. Folia Musei Historico-Naturalis Bakonyiensis - A Bakonyi Természettudományi Múzeum közleményei 25, 89-99.

LŐRINCZI G. (2011): Density and spatial pattern of nests in sub-Mediterranean grounddwelling ant communities (Hymenoptera: Formicidae). Community Ecology 12, 51-57.

LUQUE G. M. \& LÓPEZ J. R. (2007): Effect of experimental small-scale spatial heterogeneity on resource use of a Mediterranean ground-ant community. Acta Oecologica 32, 42-49.

LYNCH J. F., BALINSKY E. C., VAIL S. G. (1980): Foraging patterns in three sympatric forest ant species, Prenolepis imparis, Paratrechina melanderi and Aphaenogaster rudis (Hymenoptera: Formicidae). Ecological Entomology 5, 353-371.

MAJER J. D. (1976): The maintenance of the ant mosaic in Ghana cocoa farms. Journal of Applied Ecology 13, 123-144.

Majer J. D., Delabie J. H. C., Smith M. R. B. (1994): Arboreal ant community patterns in Brazilian cocoa farms. Biotropica 26, 73-83. 
Maravalhas J. \& Morais H. C. (2009): Association between ants and a leafhopper (Cicadellidae: Idiocerinae) in the central Brazilian cerrado. Florida Entomologist 92, 563-568.

MARKó B. \& CZECHOWSKI W. (2004): Lasius psammophilus Seifert and Formica cinerea Mayr (Hymenoptera: Formicidae) on sand dunes: conflicts and coexistence. Annales Zoologici 54, 365-378.

MARSH A. C. (1985): Microclimatic factors influencing foraging patterns and success of the thermophilic desert ant, Ocymyrmex barbiger. Insectes Sociaux 32, 286-296.

Martin P., Loreau M., Josens G. (1995): Production in the ant Leptothorax unifasciatus (Hymenoptera, Formicidae). Acta Oecologica 16, 295-311.

Maschwitz U. \& HänEl H. (1985): The migrating herdsman Dolichoderus (Diabolus) cuspidatus: an ant with a novel mode of life. Behavioral Ecology and Sociobiology 17, 171-184.

MCDonald P. (1984): Tool use by the ant, Novomessor albisetosus (Mayr). Journal of the New York Entomological Society 92, 156-161.

MCGLYNN T. P. (2012): The ecology of nest movement in social insects. Annual Review of Entomology 57, 291-308.

McGlynn T. P., CARr R. A., CARson J. H., Buma J. (2004): Frequent nest relocation in the ant Aphaenogaster araneoides: resources, competition, and natural enemies. Oikos 106, 611-621.

McIVer J. D. \& StonedAHL G. (1993): Myrmecomorphy: morphological and behavioral mimicry of ants. Annual Review of Entomology 38, 351-377.

MERCIER J. L. \& DEJEAN A. (1996): Ritualized behavior during competition for food between two Formicinae. Insectes Sociaux 43, 17-29.

MESSINA F. J. (1981): Plant protection as a consequence of an ant-membracid mutualism: interactions on goldenrod (Solidago sp.). Ecology 62, 1433-1440.

MitjaEV I. D. (1967): New and poorly known species of Homoptera, Auchenorrhyncha from East Kazakhstan. Entomologicheskoe Obozrenie 46, 712-723.

Morales M. A. (2000): Mechanisms and density dependence of benefit in an ant-membracid mutualism. Ecology 81, 482-489.

Moreira V. S. S. \& DEL-Claro K. (2005): The outcomes of an ant-treehopper association on Solanum lycocarpum St. Hill: increased membracid fecundity and reduced damage by chewing herbivores. Neotropical Entomology 34, 881-887. 
MorRILL W. L. (1972): Tool using behavior of Pogonomyrmex badius (Hymenoptera: Formicidae). Florida Entomologist 55, 59-60.

MORRISON L. W. (1996): Community organization in a recently assembled fauna: the case of Polynesian ants. Oecologia 107, 243-256.

Morrison L. W., Kawazoe E. A., Guerra R., GiLbert L. E. (2000): Ecological interactions of Pseudacteon parasitoids and Solenopsis ant hosts: environmental correlates of activity and effects on competitive hierarchies. Ecological Entomology 25, 433-444.

Moya-RAygOza G. \& NAUlt L. R. (2000): Obligatory mutualism between Dalbulus quinquenotatus (Homoptera: Cicadellidae) and attendant ants. Annals of the Entomological Society of America 93, 929-940.

MöGlich M. H. J. \& Alpert G. D. (1979): Stone dropping by Conomyrma bicolor: a new technique of interference competition. Behavioral Ecology and Sociobiology 6, 105-113.

Mueller U. G., Gerardo N. M., Aanen D. K., Six D. L., Schultz T. R. (2005): The evolution of agriculture in insects. Annual Review of Ecology, Evolution, and Systematics 36, 563-569.

MÜLler C. B. \& GodFrAY H. C. J. (1999): Predators and mutualists influence the exclusion of aphid species from natural communities. Oecologia 119, 120-125.

MYERS J. G. (1929): Observations on the biology of two remarkable cixiid planthoppers (Homoptera) from Cuba. Psyche 36, 283-292.

NEECE K. C. (1980): A faunistic survey of the organisms associated with ant colonies of West Texas (especially Solenopsis spp.). M.S. thesis, Texas Tech University, 99 pp.

NICKEL H. (2003): The leafhoppers and planthoppers of Germany (Hemiptera, Auchenorrhyncha): patterns and strategies in a highly diverse group of phytophagous insects. Pensoft Publishers, Sofia-Moscow, 460 pp.

Nickel H. \& REMANe R. (2002): Artenliste der Zikaden Deutschlands, mit Angabe von Nährpflanzen, Nahrungsbreite, Lebenszyklus, Areal und Gefährdung (Hemiptera, Fulgoromorpha et Cicadomorpha). Beiträge zur Zikadenkunde 5, 27-64.

Oliveira P. S. \& Del-Claro K. (2005): Multitrophic interactions in a neotropical savanna: ant-hemipteran systems, associated insect herbivores and a host plant. In: BURSLEM D. F. R. P., PinARd M. A., Hartley S. E. (eds.): Biotic interactions in the tropics: their role in the maintenance of species diversity. Cambridge University Press, Cambridge, UK, pp. 414-438.

Oliver T. H., LEATHER S. R., COOK J. M. (2008): Macroevolutionary patterns in the origin of mutualisms involving ants. Journal of Evolutionary Biology 21, 1597-1608. 
Palermo S., Elekes M., Botti S., Ember I., Alma A., Orosz A., Bertaccini A., Kölber M. (2004): Presence of stolbur phytoplasma in Cixiidae in Hungarian vineyards. Vitis 43, 201-203.

PALMER T. M. (2003): Spatial habitat heterogeneity influences competition and coexistence in an African acacia ant guild. Ecology 84, 2843-2855.

PALMER T. M. (2004): Wars of attrition: colony size determines competitive outcomes in a guild of African acacia ants. Animal Behaviour 68, 993-1004.

PARR C. L. (2008): Dominant ants can control assemblage species richness in a South African savanna. Journal of Animal Ecology 77, 1191-1198.

Parr C. L., Sinclair B. J., Andersen A. N., Gaston K. J., Chown S. L. (2005): Constraint and competition in assemblages: a cross-continental and modeling approach for ants. The American Naturalist 165, 481-494.

PARR C. L. \& GIBB H. (2010): Competition and the role of dominant ants. In: LACH L., PARR C. L., Аввотт K. L. (eds.): Ant ecology. Oxford University Press, Oxford, UK, pp. 77-96.

PARR C. L. \& GIBB H. (2012): The discovery-dominance trade-off is the exception, rather than the rule. Journal of Animal Ecology 81, 233-241.

Pearce-Duvet J. M. C., Moyano M., Adler F. R., Feener D. H. JR. (2011): Fast food in ant communities: how competing species find resources. Oecologia 167, 229-240.

Pekas A., Tena A., Aguilar A., Garcia-Marí F. (2011): Spatio-temporal patterns and interactions with honeydew-producing Hemiptera of ants in a Mediterranean citrus orchard. Agricultural and Forest Entomology 13, 89-97.

PERKOVSKY E. E. (2006): Occurrence of ant (Hymenoptera, Formicidae) and aphid (Homoptera, Aphidinea) syninclusions in Saxonian and Rovno ambers. Paleontological Journal 40, 190-192.

Perkovsky E. E. (2011): Syninclusions of the Eocene winter ant Prenolepis henshei (Hymenoptera: Formicidae) and Germaraphis aphids (Hemiptera: Eriosomatidae) in Late Eocene Baltic and Rovno amber: some implications. Russian Entomological Journal 20, 303-313.

PETRÁKOVÁ L. \& SCHLAGHAMERSKÝ J. (2011): Interactions between Liometopum microcephalum (Formicidae) and other dominant ant species of sympatric occurrence. Community Ecology 12, 9-17. 
Petrov I. Z. \& Gallé L. (1986): Nest distribution of the ant Cataglyphis aenescens (Nyl.) (Hymenoptera, Formicidae) in Deliblato sandy area (Yugoslavia). Ekologija 21, 135-148.

PfeIfFER M. \& LinSENMAIR K. E. (2001): Territoriality in the Malaysian giant ant Camponotus gigas (Hymenoptera/Formicidae). Journal of Ethology 19, 75-85.

Pfeiffer M. \& LinsenMaIR K. E. (2007): Trophobiosis in a tropical rainforest on Borneo: Giant ants Camponotus gigas (Hymenoptera: Formicidae) herd wax cicada Bythopsyrna circulata (Auchenorrhyncha: Flatidae). Asian Myrmecology 1, 105-119.

Pusch K., Meindl C., Heinze J. (2006): Heterospecific colony fusion in two Temnothorax (Hymenoptera: Formicidae) sibling ants. Myrmecologische Nachrichten 9, 43-46.

R Core TEAM (2013): R: A Language and Environment for Statistical Computing. R Foundation for Statistical Computing, Vienna, Austria. http://www.R-project.org/

RENKONEN O. (1938): Statistisch-ökologische Untersuchungen über die terrestrische Käferwelt der finnischen Bruchmoore. Annales Zoologici Societatis ZoologicaeBotanica Fennica Vanamo 6, 1-231.

REZNIKOVA J. I. (1982): Interspecific communication between ants. Behaviour 80, 84-95.

RiBAS C. R. \& SCHOEREDER J. H. (2002): Are all ant mosaics caused by competition? Oecologia 131, 606-611.

Riedle-Bauer M., Tiefenbrunner W., Otreba J., Hanak K., Schildberger B., Regner F. (2006): Epidemiological observations on bois noir in Austrian vineyards. Mitteilungen Klosterneuburg 56, 166-170.

RIPLEY B. D. (1979): Tests of 'randomness' for spatial point patterns. Journal of the Royal Statistical Society B 41, 368-374.

RocKwoOD L. L. (1973): Distribution, density, and dispersion of two species of Atta (Hymenoptera: Formicidae) in Guanacaste Province, Costa Rica. Journal of Animal Ecology 42, 803-817.

Room P. M. (1971): The relative distributions of ant species in Ghana's cocoa farms. Journal of Animal Ecology 40, 735-751.

Rosengren R. (1986): Competition and coexistence in an insular ant community - a manipulation experiment (Hymenoptera: Formicidae). Annales Zoologici Fennici 23, 297-302.

RÖSZlER P. (1937): Biologie der Honigameise (Prenolepis imparis v. nitens Mayr). Entomologische Rundschau 54, 207-209, 348-352, 376-380. 
RYTI R. T. (1991): Theoretical considerations of density-dependent spacing of a moundbuilding ant (Formica altipetens). Journal of Theoretical Biology 147, 289-301.

RYTI R. T. \& CASE T. J. (1984): Spatial arrangement and diet overlap between colonies of desert ants. Oecologia 62, 401-404.

RYTI R. T. \& CASE T. J. (1986): Overdispersion of ant colonies: a test of hypotheses. Oecologia 69, 446-453.

RYTI R. T. \& CASE T. J. (1992): The role of neighborhood competition in the spacing and diversity of ant communities. American Naturalist 139, 355-374.

SAKATA H. (1995): Density-dependent predation of the ant Lasius niger (Hymenoptera: Formicidae) on two attended aphids Lachnus tropicalis and Myzocallis kuricola (Homoptera: Aphididae). Researches on Population Ecology 37, 159-164.

SANDERS N. J. \& GORDON D. M. (2000): The effects of interspecific interactions on resource use and behavior in a desert ant. Oecologia 125, 436-443.

SANDERS N. J. \& GORDON D. M. (2003): Resource-dependent interactions and the organization of desert ant communities. Ecology 84, 1024-1031.

Sanders N. J., Crutsinger G. M., Dunn R. R., Majer J. D., Delabie J. H. C. (2007): An ant mosaic revisited: dominant ant species disassemble arboreal ant communities but cooccur randomly. Biotropica 39, 422-427.

SAntini G., Tucci L., OttonetTi L., Frizzi F. (2007): Competition trade-offs in the organisation of a Mediterranean ant assemblage. Ecological Entomology 32, 319-326.

SARTY M., AbBOtT K. L., LeSTER P. J. (2006): Habitat complexity facilitates coexistence in a tropical ant community. Oecologia 149, 465-473.

SAVOLAINEN R. \& VEPSÄLÄINEN K. (1988): A competition hierarchy between boreal ants: impact on resource partitioning and community structure. Oikos 51, 135-155.

SAVOLAINEN R. \& VEPSÄLÄINEN K. (1989): Niche differentiation of ant species within territories of the wood ant Formica polyctena. Oikos 56, 3-16.

Schlick-Steiner B. C., Steiner F. M., Moder K., Bruckner A., Fiedler K., Christian E. (2006): Assessing ant assemblages: pitfall trapping versus nest counting. Insectes Sociaux 53, 274-281.

SCHMID-HEMPEL P. \& CROZIER R. H. (1999): Polyandry versus polygyny versus parasites. Philosophical Transactions of the Royal Society B 354, 507-515.

SCHOOLEY R. L. \& WIENS J. A. (2003): Spatial patterns, density dependence, and demography in the harvester ant, Pogonomyrmex rugosus, in semiarid grasslands. Journal of Arid Environments 53, 183-196. 
SEIFERT B. (1992): A taxonomic revision of the Palaearctic members of the ant subgenus Lasius s. str. (Hymenoptera: Formicidae). Abhandlungen und Berichte des Naturkundemuseums Görlitz 66, 1-67.

SEIFERT B. (2007): Die Ameisen Mittel- und Nordeuropas. Lutra-Verlags-und Vertriebsgesellschaft, Görlitz, 368 pp.

SMALLWOOD J. (1982): Nest relocations in ants. Insectes Sociaux 29, 138-147.

Smallwood J. \& Culver D. C. (1979): Colony movements of some North American ants. Journal of Animal Ecology 48, 373-382.

SOARES S. M. \& Schoereder J. H. (2001): Ant-nest distribution in a remnant of tropical rainforest in southeastern Brazil. Insectes Sociaux 48, 280-286.

SPSS for Windows, Rel. 17.0.0 2008. Chicago: SPSS Inc.

Stadler B. \& Dixon A. F. G. (2005): Ecology and evolution of aphid-ant interactions. Annual Review of Ecology, Evolution, and Systematics 36, 345-372.

St. Amant R. \& Horton T. E. (2008): Revisiting the definition of tool use. Animal Behaviour 75, 1199-1208.

Stanton M. L., Palmer T. M., Young T. P. (2002): Competition-colonization trade-offs in a guild of African acacia-ants. Ecological Monographs 72, 347-363.

Steiner F. M. \& SCHLICK-STEINER B. C. (2001): Die Honigameise Prenolepis nitens (Mayr, 1852) (Hymenoptera: Formicidae) neu für Kärnten und erstmals im Gebirge. Carinthia II 191/111, 459-460.

Steiner F. M., Schlick-Steiner B. C, Holzinger W., Komposch C., Pazoutova S., SANETRA M., Christian E. (2004): A novel relationship between ants and a leafhopper (Hymenoptera: Formicidae; Hemiptera: Cicadellidae). European Journal of Entomology 101, 689-692.

Steiner F. M., Schlick-Steiner B. C., VanderWal J., Reuther K. D., Christian E., Stauffer C., Suarez A. V., Williams S. E., Crozier R. H. (2008): Combined modelling of distribution and niche in invasion biology: a case study of two invasive Tetramorium ant species. Diversity and Distributions 14, 538-545.

STONE L. \& ROBERTS A. (1990): The checkerboard score and species distributions. Oecologia 85, 74-79.

STRÄtZ M. \& HEINZE J. (2004): Colony structure and sex allocation ratios in the ant Temnothorax crassispinus. Insectes Sociaux 51, 372-377. 
Stuble K. L., Rodriguez-Cabal M. A., McCormick G. L., Jurić I., Dunn R. R., SAnders N. J. (2013): Tradeoffs, competition, and coexistence in eastern deciduous forest ant communities. Oecologia, 171, 981-992.

StukAlyuK S. V. \& RAdChENKo V. G. (2011): Structure of multi-species ant assemblages (Hymenoptera, Formicidae) in the Mountain Crimea. Entomological Review 91, 15-36.

STYRSKY J. D. \& EubANKS M. D. (2007): Ecological consequences of interactions between ants and honeydew-producing insects. Proceedings of the Royal Society of London B 274, 151-164.

Sudd J. H., Douglas J. M., Gaynard T., Murray D. M., Stockdale J. M. (1977): The distribution of wood-ants (Formica lugubris Zetterstedt) in a northern English forest. Ecological Entomology 2, 301-313.

TALbot M. (1943a): Population studies of the ant Prenolepis imparis Say. Ecology 24, 31-44.

Talbot M. (1943b): Response of the ant Prenolepis imparis Say to temperature and humidity changes. Ecology 24, 345-352.

TAMÁs J. (2003): History of Austrian pine plantations in Hungary. Acta Botanica Croatica 62, 147-158.

TANAKA T. \& ONO Y. (1978): The tool use by foragers of Aphaenogaster famelica. Japanese Journal of Ecology 28, 49-58.

TANNER C. J. \& KelLER L. (2012): Nest distribution varies with dispersal method and familiarity-mediated aggression for two sympatric ants. Animal Behaviour 84, 1151-1158.

Thomas M. L. \& Holway D. A. (2005): Condition-specific competition between invasive Argentine ants and Australian Iridomyrmex. Journal of Animal Ecology 74, 532-542.

THOMPSON C. R. (1984): Association of Paratrechina arenivaga (Hymenoptera: Formicidae), with nymphs of Oecleus borealis (Homoptera: Cixiidae). Journal of the New York Entomological Society 92, 35-41.

THOMPSOn C. R., Nickerson J. C., MEAD F. W. (1979): Nymphal habitat of Oliarus vicarius (Homoptera: Cixiidae), and possible association with Aphaenogaster and Paratrechina (Hymenoptera: Formicidae). Psyche 86, 321-326.

Traniello J. F. A. \& LeVINGS S. C. (1986): Intra- and intercolony patterns of nest dispersion in the ant Lasius neoniger: correlations with territoriality and foraging ecology. Oecologia 69, 413-419.

TSCHINKEL W. R. (1987): Seasonal life history and nest architecture of a winter-active ant, Prenolepis imparis. Insectes Sociaux 34, 143-164. 
UNDERWOOD E. C. \& FisHER B. L. (2006): The role of ants in conservation monitoring: if, when, and how. Biological Conservation 132, 166-182.

Vasconcellos A., Santana G., Souza A. K. (2004): Nest spacing and architecture, and swarming of males of Dinoponera quadriceps (Hymenoptera, Formicidae) in a remnant of the Atlantic forest in northeast Brazil. Brazilian Journal of Biology 64, 357-362.

VEPSÄLÄINEN K. \& PISARSKI B. (1982): Assembly of island ant communities. Annales Zoologici Fennici 19, 327-335.

VEPSÄLÄINEN K. \& SAVOLAINEN R. (1990): The effect of interference by formicine ants on the foraging of Myrmica. Journal of Animal Ecology 59, 643-654.

VESNIĆ A. \& LELO S. (2010): A contribution to the knowledge of distribution of the species Prenolepis nitens (Mayr, 1853) (Hymenoptera: Formicidae) in the southwest part of the Balkan Peninsula. Acta entomologica serbica 15, 121-128.

VÖRÖS G. \& GALLÉ L. (2002): Ants (Hymenoptera: Formicidae) as primary pests in Hungary: recent observations. Tiscia 33, 31-35.

VRIES H. DE (1995): An improved test of linearity in dominance hierarchies containing unknown or tied relationships. Animal Behavior 50, 1375-1389.

VRIES H. DE (1998): Finding a dominance order most consistent with a linear hierarchy: a new procedure and review. Animal Behavior 55, 827-843.

WALOFF N. \& Blackith R. E. (1962): The growth and distribution of the mounds of Lasius flavus (Fabricius) (Hymenoptera: Formicidae) in Silkwood Park, Berkshire. Journal of Animal Ecology 31, 421-437.

WARBURG I. \& STEINBERGER Y. (1997): On the spatial distribution of nests of the ants Messor arenarius and Messor ebeninus. Journal of Arid Environments 36, 671-676.

WARd P. S. (2010): Taxonomy, phylogenetics and evolution. In: LACH L., PARR C. L., Аввотт K. L. (eds.): Ant ecology. Oxford University Press, Oxford, UK, pp. 3-17.

WHEELER W. M. (1910): The habits of ants in general. In: Ants: their structure, development and behavior. Columbia University Press, New York, pp. 176-191.

WheELeR W. M. (1930): The ant Prenolepis imparis Say. Annals of the Entomological Society of America 23, 1-26.

Whitford W. G., DePreE E., Johnson P. (1980): Foraging ecology of two Chihuahuan Desert ant species: Novomessor cockerelli and Novomessor albisetosus. Insectes Sociaux 27, 148-156.

Wiernasz D. C. \& Cole B. J. (1995): Spatial distribution of Pogonomyrmex occidentalis: recruitment, mortality and overdispersion. Journal of Animal Ecology 64, 519-527. 
Wiescher P. T., Pearce-Duvet J. M. C., FeEner D. H. (2011): Environmental context alters ecological trade-offs controlling ant coexistence in a spatially heterogeneous region. Ecological Entomology 36, 549-559.

Wike L. D., Martin F. D., Paller M. H., Nelson E. A. (2010): Impact of forest seral stage on use of ant communities for rapid assessment of terrestrial ecosystem health. Journal of Insect Science 10, 1-16.

WILsON E. O. (1971): The insect societies. Belknap Press of Harvard University Press, Cambridge, MA, USA, 548 pp.

WILSON E. O. (1990): Success and dominance in ecosystems: the case of the social insects. Ecology Institute, Oldendorf/Luhe, Germany, 104 pp.

WiLson E. O. \& HöLldobler B. (2005): The rise of the ants: a phylogenetic and ecological explanation. Proceedings of the National Academy of Sciences of the United States of America 102, 7411-7414.

Wittman S. E., Sanders N. J., Ellison A. M., Jules E. S., Ratchford J. S., Gotelli N. J. (2010): Species interactions and thermal constraints on ant community structure. Oikos 119, 551-559. 


\section{Köszönetnyilvánítás}

Legnagyobb köszönettel és hálával témavezetőmnek, Dr. Gallé Lászlónak tartozom, aki annak idején elindított azon az úton, amelynek eredménye ez a dolgozat lett, és akinek szakmai tanácsai, iránymutatásai nem csupán a doktori kutatásaim és e disszertáció megírása, de az egyetemi oktatás során is igen hasznosnak és követendőnek bizonyultak.

Hálával tartozom Márton Juditnak, aki sokat segített az egyes, angol szakirodalomban használatos kifejezések, definíciók magyarra ültetésében, valamint jó néhány helyesírással kapcsolatos kérdés tisztázásában, és aki a dolgozat angol nyelvü összefoglalóját is tüzetesen átnézte.

Köszönöm Dr. Barta Zoltánnak (Debreceni Egyetem, Evolúciós Állattani és Humánbiológiai Tanszék), hogy a dominancia-hierarchiák linearitásának teszteléséhez rendelkezésemre bocsátotta az által írt és fejlesztett $\mathrm{C}$ programot, Medve Zoltánnak pedig a program tesztelésében és futtatásában nyújtott nélkülözhetetlen segítségét.

Tanszéki kollégáim közül köszönettel tartozom Maák Elek Istvánnak az inspiráló beszélgetésekért, Dr. Pénzes Zsoltnak és Dr. Gallé Róbertnek az adatelemzésében nyújtott segítségükért, valamint Dr. Györffy Györgynek, aki a hangyafészkekből gyüjtött recéskabócák meghatározásában volt nagy segítségemre.

Végül, de nem utolsó sorban hálásan köszönöm családtagjaimnak, hogy személyes támogatásukkal, bátorításukkal és türelmükkel hozzájárultak a kutatásaim sikeres lefolytatásához és e disszertáció létrejöttéhez. 


\section{Függelékek}
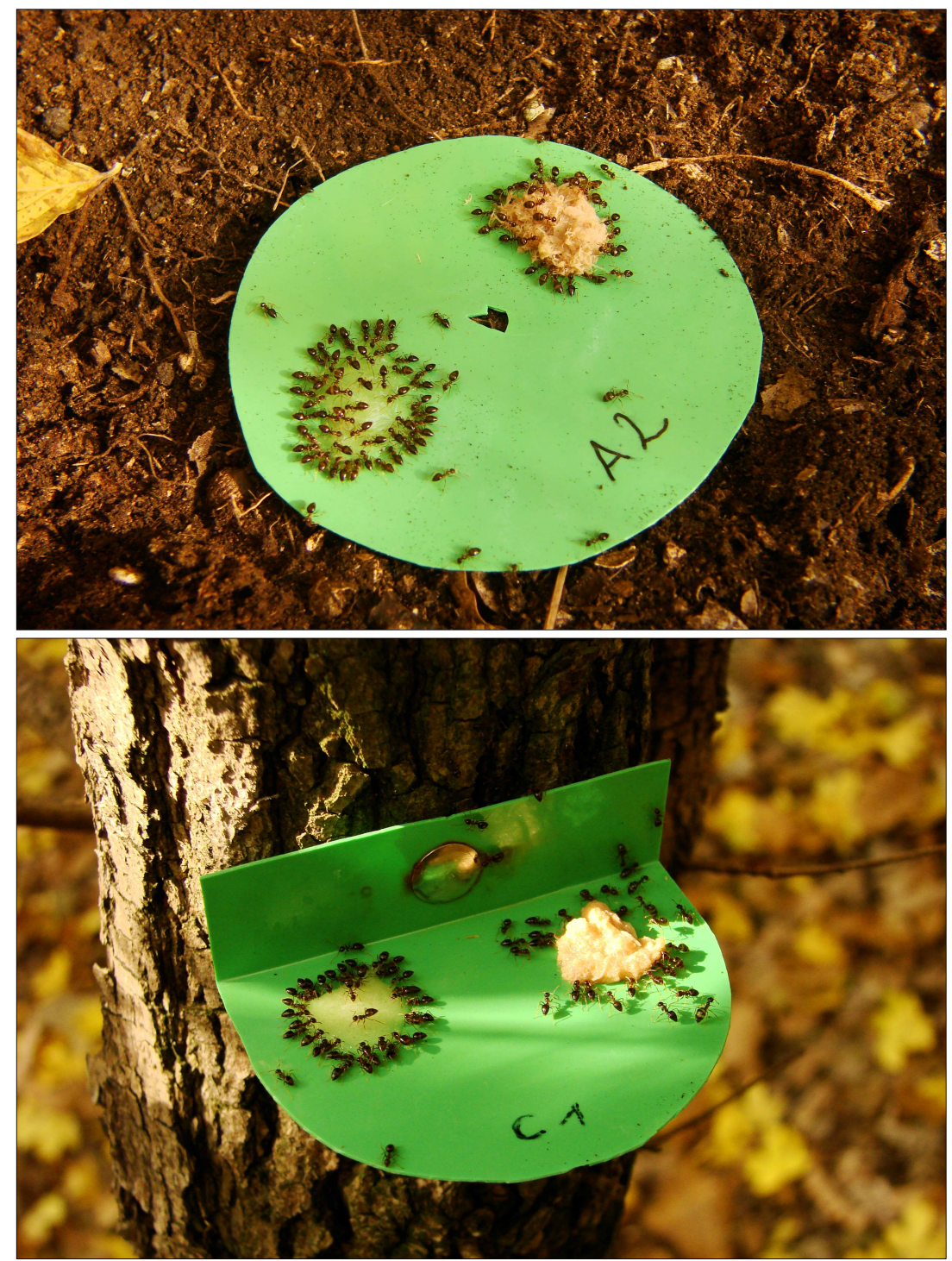

1. ábra. A csalétkes vizsgálatok során alkalmazott, talajra, ill. fák törzsére elhelyezett csalétkek (rajtuk Prenolepis nitens dolgozókkal). 
1. táblázat. A térképezések során detektált fészkek száma az egyes mintavételi napokon a füredi tölgyesben. PrNi: Prenolepis nitens; ApSu: Aphaenogaster subterranea; TeCr: Temnothorax crassispinus; TePa: Temnothorax parvulus; LaBr: Lasius brunneus; LaEm: Lasius emarginatus; MyGr: Myrmecina graminicola; PoCo: Ponera coarctata; FoGa: Formica gagates.

\begin{tabular}{lccccccccc}
\hline & $\mathrm{PrNi}$ & $\mathrm{ApSu}$ & $\mathrm{TeCr}$ & $\mathrm{TePa}$ & $\mathrm{LaBr}$ & $\mathrm{LaEm}$ & $\mathrm{MyGr}$ & PoCo & FoGa \\
\cline { 2 - 9 } ápr. 2. & 17 & 16 & 0 & 0 & 1 & 0 & 0 & 0 & 0 \\
ápr. 9. & 34 & 18 & 3 & 1 & 3 & 0 & 1 & 0 & 1 \\
ápr. 26. & 27 & 16 & 5 & 3 & 3 & 1 & 1 & 1 & 0 \\
jún. 12. & 10 & 14 & 4 & 0 & 5 & 0 & 2 & 1 & 1 \\
jún. 28. & 11 & 14 & 7 & 4 & 0 & 3 & 0 & 0 & 0 \\
júl. 8. & 8 & 16 & 5 & 3 & 3 & 0 & 2 & 1 & 0 \\
aug. 17. & 14 & 10 & 1 & 1 & 0 & 0 & 1 & 0 & 1 \\
aug. 27. & 9 & 15 & 0 & 4 & 0 & 2 & 0 & 0 & 1 \\
szept. 13. & 24 & 6 & 0 & 4 & 0 & 1 & 0 & 1 & 0 \\
okt. 9. & 6 & 3 & 0 & 1 & 1 & 1 & 0 & 0 & 0 \\
okt. 16. & 19 & 5 & 2 & 0 & 0 & 0 & 0 & 0 & 0 \\
okt. 22. & 18 & 6 & 4 & 0 & 0 & 0 & 0 & 0 & 0 \\
\hline Összesen: & 197 & 139 & 31 & 21 & 16 & 8 & 7 & 4 & 4 \\
\hline
\end{tabular}


2. táblázat. A térképezések során detektált fészkek száma az egyes mintavételi napokon a litéri fenyvesben. ApSu: Aphaenogaster subterranea; LaEm: Lasius emarginatus; FoFu: Formica fusca; TeCr: Temnothorax crassispinus; PoCo: Ponera coarctata; LaUm: Lasius umbratus; TeUn: Temnothorax unifasciatus; CaLi: Camponotus ligniperdus; MyGr: Myrmecina graminicola; TePa: Temnothorax parvulus; LaMy: Lasius myops; MySa: Myrmica sabuleti; FoGa: Formica gagates; PITa: Plagiolepis taurica; CaAe: Camponotus aethiops.

\begin{tabular}{|c|c|c|c|c|c|c|c|c|c|c|c|c|c|c|c|}
\hline & $\mathrm{ApSu}$ & $\mathrm{LaEm}$ & $\mathrm{FoFu}$ & $\mathrm{TeCr}$ & PoCo & LaUm & TeUn & $\mathrm{CaLi}$ & MyGr & $\mathrm{TePa}$ & LaMy & MySa & FoGa & $\mathrm{PlTa}$ & $\mathrm{CaAe}$ \\
\hline máj. 1. & 9 & 2 & 9 & 2 & 7 & 0 & 2 & 0 & 1 & 0 & 0 & 0 & 0 & 0 & 0 \\
\hline máj. 9. & 6 & 5 & 5 & 2 & 3 & 0 & 0 & 0 & 3 & 4 & 0 & 1 & 0 & 0 & 1 \\
\hline máj. 29. & 15 & 2 & 4 & 4 & 2 & 0 & 1 & 8 & 0 & 0 & 0 & 2 & 0 & 1 & 0 \\
\hline jún. 27. & 14 & 10 & 5 & 1 & 2 & 5 & 1 & 2 & 0 & 0 & 0 & 0 & 0 & 1 & 0 \\
\hline júl. 4. & 6 & 12 & 3 & 6 & 3 & 3 & 1 & 0 & 1 & 0 & 0 & 0 & 0 & 0 & 0 \\
\hline júl. 11. & 10 & 25 & 7 & 2 & 1 & 0 & 1 & 1 & 0 & 0 & 0 & 0 & 0 & 0 & 0 \\
\hline aug. 22 . & 9 & 2 & 4 & 4 & 8 & 2 & 2 & 3 & 0 & 1 & 0 & 1 & 0 & 0 & 0 \\
\hline szept. 12. & 3 & 9 & 5 & 4 & 1 & 13 & 4 & 1 & 1 & 0 & 0 & 0 & 0 & 0 & 0 \\
\hline szept. 18. & 4 & 5 & 0 & 0 & 1 & 0 & 2 & 0 & 0 & 0 & 0 & 0 & 3 & 0 & 0 \\
\hline okt. 11. & 1 & 0 & 3 & 0 & 0 & 0 & 2 & 1 & 0 & 0 & 4 & 0 & 0 & 0 & 0 \\
\hline okt. 15. & 1 & 0 & 0 & 0 & 0 & 0 & 2 & 0 & 0 & 0 & 0 & 0 & 0 & 0 & 0 \\
\hline okt. 24. & 4 & 1 & 5 & 5 & 0 & 0 & 3 & 0 & 2 & 1 & 0 & 0 & 0 & 0 & 0 \\
\hline Összesen: & 82 & 73 & 50 & 30 & 28 & 23 & 21 & 16 & 8 & 6 & 4 & 4 & 3 & 2 & 1 \\
\hline
\end{tabular}


3. táblázat. A legközelebbi fészekszomszédok identitása a füredi tölgyesben az egész évre összegezve. Az egyes cellákban szereplő számok azon esetek számát jelölik, amikor $j$-fajok az $i$-fajok legközelebbi szomszédjai voltak. PrNi: Prenolepis nitens; ApSu: Aphaenogaster subterranea; TeCr: Temnothorax crassispinus; TePa: Temnothorax parvulus; LaBr: Lasius brunneus; LaEm: Lasius emarginatus; MyGr: Myrmecina graminicola; PoCo: Ponera coarctata; FoGa: Formica gagates.

\begin{tabular}{|c|c|c|c|c|c|c|c|c|c|c|}
\hline & & \multicolumn{9}{|c|}{ Fajok (j) } \\
\hline & & PrNi & $\mathrm{ApSu}$ & $\mathrm{TeCr}$ & $\mathrm{TePa}$ & $\mathrm{LaBr}$ & LaEm & $\mathrm{MyGr}$ & PoCo & FoGa \\
\hline \multirow{9}{*}{ 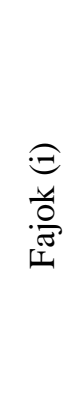 } & $\mathrm{PrNi}$ & 81 & 82 & 14 & 4- & 9 & 4 & 2 & 0 & 1 \\
\hline & $\mathrm{ApSu}$ & 77 & 29- & 13 & $11+$ & 4 & 0- & 2 & 1 & 2 \\
\hline & $\mathrm{TeCr}$ & 15 & 13 & 1- & 0 & 0 & 1 & 1 & 0 & 0 \\
\hline & $\mathrm{TePa}$ & 8 & 8 & 0 & 1 & $3+$ & 1 & 0 & 0 & 0 \\
\hline & $\mathrm{LaBr}$ & 7 & 6 & 0 & 2 & 1 & 0 & 0 & 0 & 0 \\
\hline & LaEm & 2 & 2 & 2 & 0 & 0 & $2+$ & 0 & 0 & 0 \\
\hline & MyGr & 3 & 3 & 0 & 0 & 0 & 0 & 0 & 0 & 1 \\
\hline & PoCo & 1 & 2 & 1 & 0 & 0 & 0 & 0 & 0 & 0 \\
\hline & FoGa & 1 & 2 & 0 & 0 & 0 & 0 & 1 & 0 & 0 \\
\hline
\end{tabular}

+: a vártnál több megfigyelés; -: a vártnál kevesebb megfigyelés 
4. táblázat. A legközelebbi fészekszomszédok identitása a litéri fenyvesben az egész évre összegezve. Az egyes cellákban szereplő számok azon esetek számát jelölik, amikor j-fajok az i-fajok legközelebbi szomszédjai voltak. ApSu: Aphaenogaster subterranea; LaEm: Lasius emarginatus; FoFu: Formica fusca; TeCr: Temnothorax crassispinus; PoCo: Ponera coarctata; LaUm: Lasius umbratus; TeUn: Temnothorax unifasciatus; CaLi: Camponotus ligniperdus; MyGr: Myrmecina graminicola; TePa: Temnothorax parvulus; LaMy: Lasius myops; MySa: Myrmica sabuleti; FoGa: Formica gagates; PITa: Plagiolepis taurica; CaAe: Camponotus aethiops.

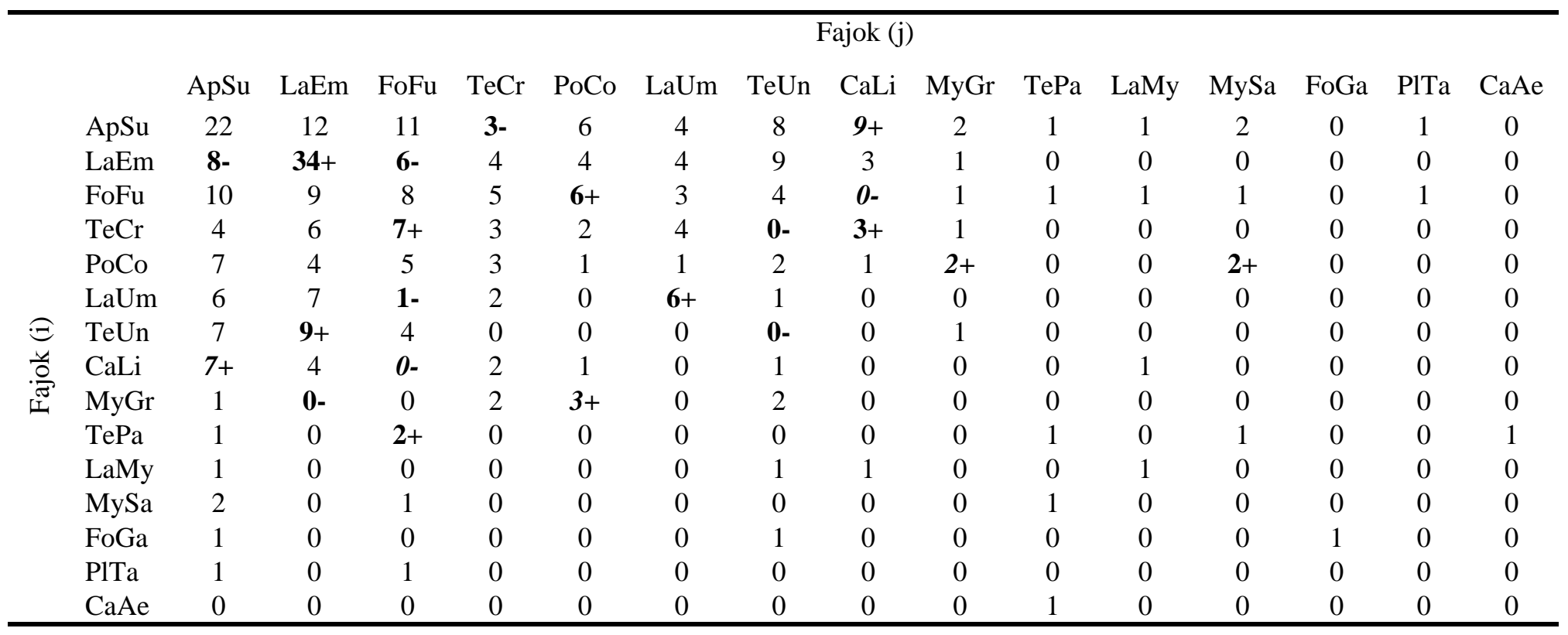

+: a vártnál több megfigyelés; -: a vártnál kevesebb megfigyelés 
5. táblázat. A csalétkezések során regisztrált fajok egyedszáma (a), ill. a térben és időben elfoglalt csalétkek száma (b) a füredi tölgyesben. ApSu: Aphaenogaster subterranea; PrNi: Prenolepis nitens; FoGa: Formica gagates; Te: Temnothorax spp.; LiMi: Liometopum microcephalum; CrSm: Crematogaster schmidti; LaBr: Lasius brunneus; LaEm: Lasius emarginatus; CaFa: Camponotus fallax; CaTr: Camponotus truncatus.

\begin{tabular}{|c|c|c|c|c|c|c|c|c|c|c|}
\hline (a) & $\mathrm{ApSu}$ & $\mathrm{PrNi}$ & FoGa & $\mathrm{Te}$ & LiMi & $\mathrm{CrSm}$ & $\mathrm{LaBr}$ & $\mathrm{LaEm}$ & $\mathrm{CaFa}$ & $\mathrm{CaTr}$ \\
\hline ápr. 3. & 169 & 9076 & 300 & 108 & 1506 & 0 & 0 & 0 & 0 & 1 \\
\hline ápr. 17. & 1 & 8115 & 22 & 120 & 517 & 188 & 0 & 0 & 0 & 0 \\
\hline máj. 7. & 3 & 18302 & 194 & 88 & 80 & 0 & 84 & 0 & 0 & 0 \\
\hline jún. 18. & 6680 & 541 & 324 & 606 & 1553 & 0 & 718 & 568 & 3 & 0 \\
\hline jún. 27. & 2927 & 1482 & 28 & 297 & 2755 & 836 & 640 & 0 & 1 & 0 \\
\hline júl. 10. & 2801 & 0 & 63 & 354 & 0 & 716 & 608 & 42 & 0 & 1 \\
\hline aug. 12 . & 576 & 4350 & 4 & 185 & 0 & 10 & 130 & 0 & 1 & 0 \\
\hline aug. 29. & 426 & 2683 & 3 & 109 & 0 & 0 & 1 & 0 & 0 & 0 \\
\hline szept. 10. & 418 & 5825 & 12 & 41 & 0 & 117 & 0 & 0 & 0 & 0 \\
\hline okt. 10. & 2 & 6504 & 0 & 1 & 0 & 0 & 0 & 0 & 0 & 0 \\
\hline okt. 29. & 0 & 10678 & 0 & 0 & 0 & 0 & 0 & 0 & 0 & 0 \\
\hline nov. 6. & 0 & 12601 & 0 & 0 & 0 & 0 & 0 & 0 & 0 & 0 \\
\hline Összesen: & 14003 & 80157 & 950 & 1909 & 6411 & 1867 & 2181 & 610 & 5 & 2 \\
\hline (b) & $\mathrm{ApSu}$ & $\mathrm{PrNi}$ & FoGa & $\mathrm{Te}$ & LiMi & $\mathrm{CrSm}$ & $\mathrm{LaBr}$ & $\mathrm{LaEm}$ & $\mathrm{CaFa}$ & $\mathrm{CaTr}$ \\
\hline ápr. 3. & 29 & 211 & 32 & 52 & 20 & 0 & 0 & 0 & 0 & 1 \\
\hline ápr. 17. & 1 & 234 & 14 & 55 & 13 & 5 & 0 & 0 & 0 & 0 \\
\hline máj. 7. & 3 & 286 & 32 & 34 & 5 & 0 & 4 & 0 & 0 & 0 \\
\hline jún. 18. & 204 & 27 & 35 & 150 & 22 & 0 & 19 & 19 & 3 & 0 \\
\hline jún. 27. & 178 & 55 & 23 & 102 & 32 & 20 & 25 & 0 & 1 & 0 \\
\hline júl. 10. & 175 & 0 & 26 & 122 & 0 & 23 & 39 & 4 & 0 & 1 \\
\hline aug. 12 . & 82 & 138 & 4 & 63 & 0 & 2 & 8 & 0 & 1 & 0 \\
\hline aug. 29. & 82 & 57 & 3 & 49 & 0 & 0 & 1 & 0 & 0 & 0 \\
\hline szept. 10. & 67 & 134 & 11 & 23 & 0 & 10 & 0 & 0 & 0 & 0 \\
\hline okt. 10. & 2 & 198 & 0 & 1 & 0 & 0 & 0 & 0 & 0 & 0 \\
\hline okt. 29. & 0 & 192 & 0 & 0 & 0 & 0 & 0 & 0 & 0 & 0 \\
\hline nov. 6. & 0 & 201 & 0 & 0 & 0 & 0 & 0 & 0 & 0 & 0 \\
\hline Összesen: & 823 & 1733 & 180 & 651 & 92 & 60 & 96 & 23 & 5 & 2 \\
\hline
\end{tabular}


6. táblázat. A csalétkezések során regisztrált fajok egyedszáma (a), ill. a térben és időben elfoglalt csalétkek száma (b) a litéri fenyvesben. ApSu: Aphaenogaster subterranea; FoFu: Formica fusca; Te: Temnothorax spp.; LaEm: Lasius emarginatus; FoGa: Formica gagates; MySa: Myrmica sabuleti; CaLi: Camponotus ligniperdus; CaFa: Camponotus fallax; PITa: Plagiolepis taurica; FoPr: Formica pratensis; MySc: Myrmica schencki.

\begin{tabular}{|c|c|c|c|c|c|c|c|c|c|c|c|}
\hline (a) & $\mathrm{ApSu}$ & $\mathrm{FoFu}$ & $\mathrm{Te}$ & LaEm & FoGa & MySa & $\mathrm{CaLi}$ & $\mathrm{CaFa}$ & $\mathrm{PITa}$ & $\mathrm{FoPr}$ & MySc \\
\hline ápr. 18. & 16 & 84 & 402 & 298 & 94 & 205 & 2 & 0 & 0 & 72 & 0 \\
\hline ápr. 23. & 93 & 110 & 400 & 566 & 34 & 173 & 3 & 5 & 41 & 12 & 0 \\
\hline máj. 10. & 276 & 912 & 376 & 765 & 569 & 20 & 117 & 1 & 21 & 0 & 11 \\
\hline jún. 13. & 1822 & 133 & 31 & 1284 & 229 & 148 & 5 & 3 & 0 & 0 & 0 \\
\hline jún. 21. & 887 & 186 & 15 & 337 & 53 & 0 & 5 & 6 & 0 & 0 & 0 \\
\hline júl. 4. & 1495 & 325 & 60 & 266 & 243 & 451 & 2 & 7 & 0 & 0 & 0 \\
\hline aug. 15 . & 872 & 438 & 36 & 16 & 0 & 0 & 7 & 2 & 0 & 0 & 0 \\
\hline aug. 22 . & 1331 & 655 & 18 & 237 & 249 & 0 & 8 & 2 & 0 & 0 & 0 \\
\hline szept. 4. & 1002 & 227 & 61 & 0 & 53 & 251 & 1 & 1 & 0 & 25 & 0 \\
\hline okt. 3. & 92 & 161 & 0 & 0 & 0 & 89 & 0 & 1 & 0 & 0 & 0 \\
\hline okt. 17. & 4 & 9 & 0 & 0 & 12 & 0 & 0 & 0 & 0 & 0 & 0 \\
\hline okt. 31. & 56 & 1 & 0 & 0 & 0 & 0 & 1 & 0 & 0 & 0 & 0 \\
\hline Összesen: & 7946 & 3241 & 1399 & 3769 & 1536 & 1337 & 151 & 28 & 62 & 109 & 11 \\
\hline (b) & $\mathrm{ApSu}$ & $\mathrm{FoFu}$ & $\mathrm{Te}$ & LaEm & FoGa & MySa & $\mathrm{CaLi}$ & $\mathrm{CaFa}$ & $\mathrm{PITa}$ & $\mathrm{FoPr}$ & MySc \\
\hline ápr. 18. & 4 & 60 & 125 & 23 & 27 & 26 & 2 & 0 & 0 & 31 & 0 \\
\hline ápr. 23. & 22 & 59 & 112 & 44 & 22 & 11 & 3 & 5 & 4 & 7 & 0 \\
\hline máj. 10. & 46 & 171 & 115 & 33 & 30 & 6 & 60 & 1 & 4 & 0 & 2 \\
\hline jún. 13. & 91 & 84 & 27 & 86 & 22 & 8 & 5 & 2 & 0 & 0 & 0 \\
\hline jún. 21. & 94 & 124 & 15 & 50 & 19 & 0 & 5 & 5 & 0 & 0 & 0 \\
\hline júl. 4. & 111 & 135 & 33 & 50 & 36 & 18 & 2 & 6 & 0 & 0 & 0 \\
\hline aug. 15 . & 104 & 164 & 24 & 6 & 0 & 0 & 7 & 2 & 0 & 0 & 0 \\
\hline aug. 22 . & 88 & 182 & 10 & 11 & 32 & 0 & 8 & 2 & 0 & 0 & 0 \\
\hline szept. 4. & 67 & 113 & 30 & 0 & 10 & 14 & 1 & 1 & 0 & 9 & 0 \\
\hline okt. 3 . & 25 & 82 & 0 & 0 & 0 & 4 & 0 & 1 & 0 & 0 & 0 \\
\hline okt. 17. & 1 & 7 & 0 & 0 & 5 & 0 & 0 & 0 & 0 & 0 & 0 \\
\hline okt. 31. & 13 & 1 & 0 & 0 & 0 & 0 & 1 & 0 & 0 & 0 & 0 \\
\hline Összesen: & 666 & 1182 & 491 & 303 & 203 & 87 & 94 & 25 & 8 & 47 & 2 \\
\hline
\end{tabular}


7. táblázat. A gyakoribb fajok csalétek felfedezési hatékonysága és ideje (zárójelben az adott napon látogatott/elfoglalt csalétkek száma) a füredi tölgyesben.

\begin{tabular}{|c|c|c|c|c|c|c|}
\hline & \multicolumn{3}{|l|}{ A. subterranea } & \multicolumn{3}{|l|}{ P. nitens } \\
\hline & $\begin{array}{c}\text { látogatott } \\
\text { csalétkeken }\end{array}$ & $\begin{array}{c}\text { elfoglalt } \\
\text { csalétkeken }^{2}\end{array}$ & $\begin{array}{l}\text { felfedezési } \\
\text { idő }^{3}\end{array}$ & $\begin{array}{c}\text { látogatott } \\
\text { csalétkeken }\end{array}$ & $\begin{array}{c}\text { elfoglalt } \\
\text { csalétkeken }\end{array}$ & $\begin{array}{l}\text { felfedezési } \\
\text { idő }\end{array}$ \\
\hline ápr. 3. & $0,25(8)$ & $0,33(3)$ & $4,25 \pm 3,24$ & $0,73(22)$ & $0,79(19)$ & $2,27 \pm 2,68$ \\
\hline ápr. 17. & $0,00(1)$ & $0,00(0)$ & $6,00 \pm 0,00$ & $0,92(24)$ & $0,95(21)$ & $2,21 \pm 1,41$ \\
\hline máj. 7. & $0,00(1)$ & $0,00(0)$ & $5,00 \pm 0,00$ & $0,93(30)$ & $1,00(25)$ & $2,10 \pm 1,12$ \\
\hline jún. 18. & $0,30(23)$ & $0,39(18)$ & $2,39 \pm 3,03$ & $0,50(8)$ & $0,50(2)$ & $4,50 \pm 3,96$ \\
\hline jún. 27. & $0,67(21)$ & $0,65(17)$ & $2,10 \pm 1,92$ & $0,40(10)$ & $0,29(7)$ & $3,20 \pm 2,25$ \\
\hline júl. 10. & $0,70(20)$ & $0,67(18)$ & $1,80 \pm 1,32$ & - & - & - \\
\hline aug. 12 . & $0,46(13)$ & $0,50(8)$ & $3,00 \pm 2,52$ & $0,50(16)$ & $0,46(13)$ & $3,06 \pm 2,02$ \\
\hline aug. 29. & $0,77(13)$ & $0,80(10)$ & $2,31 \pm 0,95$ & $0,50(6)$ & $0,50(6)$ & $2,50 \pm 1,38$ \\
\hline szept. 10. & $0,78(9)$ & $0,86(7)$ & $2,56 \pm 1,74$ & $0,87(15)$ & $0,92(12)$ & $2,40 \pm 1,64$ \\
\hline okt. 10. & $0,00(1)$ & $0,00(0)$ & $8,00 \pm 0,00$ & $1,00(25)$ & $1,00(20)$ & $2,40 \pm 1,91$ \\
\hline okt. 29. & - & - & - & $1,00(22)$ & 1,00 (19) & $2,14 \pm 2,34$ \\
\hline \multirow[t]{3}{*}{ nov. 6.} & - & - & - & $1,00(28)$ & $1,00(23)$ & $3,07 \pm 2,23$ \\
\hline & \multicolumn{3}{|c|}{ Temnothorax spp. } & \multicolumn{3}{|l|}{$F$. gagates } \\
\hline & $\begin{array}{l}\text { látogatott } \\
\text { csalétkeken }\end{array}$ & $\begin{array}{c}\text { elfoglalt } \\
\text { csalétkeken }\end{array}$ & $\begin{array}{l}\text { felfedezési } \\
\text { idő }\end{array}$ & $\begin{array}{c}\text { látogatott } \\
\text { csalétkeken }\end{array}$ & $\begin{array}{c}\text { elfoglalt } \\
\text { csalétkeken }\end{array}$ & $\begin{array}{l}\text { felfedezési } \\
\text { idő }\end{array}$ \\
\hline ápr. 3. & $0,06(16)$ & $0,00(7)$ & $6,19 \pm 2,40$ & $0,14(7)$ & $0,00(2)$ & $4,71 \pm 2,21$ \\
\hline ápr. 17. & $0,00(18)$ & $0,00(9)$ & $5,83 \pm 1,62$ & $0,14(7)$ & $0,00(1)$ & $5,00 \pm 1,83$ \\
\hline máj. 7. & $0,00(9)$ & $0,00(4)$ & $4,67 \pm 1,41$ & $0,00(8)$ & $0,00(3)$ & $6,25 \pm 3,15$ \\
\hline jún. 18. & $0,20(25)$ & $0,14(21)$ & $3,12 \pm 2,62$ & $0,00(7)$ & $0,50(2)$ & $5,00 \pm 4,24$ \\
\hline jún. 27. & $0,05(21)$ & $0,07(14)$ & $3,86 \pm 2,78$ & $0,13(8)$ & 0,00 (4) & $6,25 \pm 2,19$ \\
\hline júl. 10. & $0,33(21)$ & $0,21(14)$ & $3,86 \pm 2,67$ & $0,25(8)$ & $0,33(3)$ & $6,75 \pm 2,82$ \\
\hline aug. 12. & $0,00(12)$ & $0,00(8)$ & $6,00 \pm 2,17$ & 0,67 (3) & $0,00(0)$ & $5,00 \pm 0,00$ \\
\hline aug. 29. & $0,00(10)$ & $0,00(6)$ & $5,50 \pm 2,55$ & $0,00(2)$ & $0,00(0)$ & $6,00 \pm 2,83$ \\
\hline szept. 10. & $0,11(9)$ & $0,00(3)$ & $7,88 \pm 3,68$ & $0,20(5)$ & $1,00(1)$ & $5,60 \pm 2,07$ \\
\hline okt. 10. & $0,00(1)$ & $0,00(0)$ & $9,00 \pm 0,00$ & - & - & - \\
\hline okt. 29. & - & - & - & - & - & - \\
\hline nov. 6. & - & - & - & - & - & - \\
\hline
\end{tabular}


8. táblázat. A gyakoribb fajok csalétek felfedezési hatékonysága és ideje (zárójelben az adott napon látogatott/elfoglalt csalétkek száma) a litéri fenyvesben.

\begin{tabular}{|c|c|c|c|c|c|c|c|c|c|c|c|c|c|}
\hline & \multicolumn{5}{|l|}{ A. subterranea } & \multicolumn{5}{|c|}{ F. fusca } & \multicolumn{3}{|c|}{ Temnothorax spp. } \\
\hline & $\begin{array}{c}\text { látogatott } \\
\text { csalétkeken }\end{array}$ & \multicolumn{2}{|c|}{$\begin{array}{c}\text { elfoglalt } \\
\text { csalétkeken }^{2}\end{array}$} & \multicolumn{2}{|c|}{$\begin{array}{l}\text { felfedezési } \\
\text { idő }^{3}\end{array}$} & \multicolumn{2}{|c|}{$\begin{array}{l}\text { látogatott } \\
\text { csalétkeken }\end{array}$} & $\begin{array}{c}\text { elfoglalt } \\
\text { csalétkeken }\end{array}$ & \multicolumn{2}{|c|}{$\begin{array}{l}\text { felfedezési } \\
\text { idő }\end{array}$} & $\begin{array}{c}\text { látogatott } \\
\text { csalétkeken }\end{array}$ & $\begin{array}{c}\text { elfoglalt } \\
\text { csalétkeken }\end{array}$ & $\begin{array}{l}\text { felfedezési } \\
\text { idő }\end{array}$ \\
\hline ápr. 18. & $0,00(1)$ & \multicolumn{2}{|c|}{$1,00(1)$} & \multicolumn{2}{|c|}{$9,00 \pm 0,00$} & \multicolumn{2}{|c|}{$0,50(16)$} & $0,86(7)$ & \multicolumn{2}{|c|}{$5,25 \pm 2,93$} & $0,22(18)$ & $0,13(16)$ & $4,89 \pm 2,45$ \\
\hline ápr. 23. & $0,43(7)$ & \multicolumn{2}{|c|}{$0,50(2)$} & \multicolumn{2}{|c|}{$3,71 \pm 3,45$} & \multicolumn{2}{|c|}{$0,17(18)$} & $0,29(7)$ & \multicolumn{2}{|c|}{$7,39 \pm 2,85$} & $0,47(17)$ & $0,50(14)$ & $4,65 \pm 2,23$ \\
\hline máj. 10. & $0,10(10)$ & \multicolumn{2}{|c|}{$0,20(5)$} & \multicolumn{2}{|c|}{$4,10 \pm 2,18$} & \multicolumn{2}{|c|}{$0,38(26)$} & 0,47 (19) & \multicolumn{2}{|c|}{$4,08 \pm 1,76$} & $0,22(23)$ & $0,42(12)$ & $4,70 \pm 2,95$ \\
\hline jún. 13. & $0,57(14)$ & \multicolumn{2}{|c|}{$0,60(10)$} & $2,71 \pm$ & & & (20) & $0,60(10)$ & $4,35 \pm$ & 37 & $0,08(13)$ & $0,50(2)$ & $6,54 \pm 3,60$ \\
\hline jún. 21. & $0,25(12)$ & 0,27 & 11) & $1,75 \pm$ & & & (27) & $0,33(18)$ & $2,84 \pm$ & & $0,10(10)$ & $0,00(0)$ & $6,50 \pm 3,31$ \\
\hline júl. 4. & $0,46(13)$ & 0,50 & 12) & $3,46 \pm$ & & & (25) & $0,44(18)$ & $3,50 \pm$ & & $0,30(10)$ & $0,50(4)$ & $4,80 \pm 3,16$ \\
\hline aug. 15 . & 0,77 (13) & 0,91 & 11) & $1,46 \pm$ & & & (28) & $0,48(21)$ & $4,00 \pm$ & & $0,00(9)$ & $0,00(2)$ & $7,67 \pm 3,16$ \\
\hline aug. 22 . & $0,69(13)$ & 0,7 & & $2,77 \pm$ & & & (28) & $0,54(24)$ & $3,82 \pm$ & & $0,00(5)$ & $0,00(1)$ & $9,80 \pm 2,17$ \\
\hline szept. 4. & $0,75(12)$ & 0,8 & & $3,25 \pm$ & & & (23) & $0,53(17)$ & $4,48 \pm$ & & $0,13(8)$ & $0,00(3)$ & $6,57 \pm 3,91$ \\
\hline okt. 3 . & $0,83(6)$ & 1,0 & & $4,50 \pm$ & & & (19) & 0,77 (13) & $5,84 \pm$ & & - & - & - \\
\hline okt. 17. & $1,00(1)$ & 0,0 & & $10,00 \pm$ & & & (3) & $1,00(1)$ & $7,33 \pm$ & & - & - & - \\
\hline okt. 31. & $1,00(7)$ & 1,0 & & $8,14 \pm$ & & & (1) & $0,00(0)$ & $7,00 \pm$ & & - & - & - \\
\hline & & & L. er & irginatu. & & & & $F . g$ & ates & & & & \\
\hline & & & $\begin{array}{r}\text { lát } \\
\text { csa }\end{array}$ & $\begin{array}{l}\text { gatott } \\
\text { tkeken }\end{array}$ & & $\begin{array}{l}\text { alt } \\
\text { eken }\end{array}$ & $\begin{array}{r}\text { felfe } \\
\text { is }\end{array}$ & $\begin{array}{r}\text { lá } \\
\text { csa }\end{array}$ & $\begin{array}{l}\text { gatott } \\
\text { keken }\end{array}$ & $\begin{array}{c}\text { elfoglalt } \\
\text { csalétkeken }\end{array}$ & $\begin{array}{r}\text { felfed } \\
\text { id }\end{array}$ & & \\
\hline & & ápr. 18. & & $3(3)$ & & & 3,33 & & $5(4)$ & $0,25(4)$ & $3,50 \pm$ & & \\
\hline & & ápr. 23. & & $7(6)$ & & & 4,33 & & $0(8)$ & $0,33(3)$ & $3,38 \pm$ & & \\
\hline & & máj. 10. & & $0(4)$ & & & 4,50 & & $0(5)$ & $1,00(3)$ & $2,20 \pm$ & & \\
\hline & & jún. 13. & & (13) & & & 4,54 & & $3(3)$ & $0,00(2)$ & $1,67 \pm$ & & \\
\hline & & jún. 21. & & $3(6)$ & & & 1,50 & & $0(5)$ & $0,00(2)$ & $5,20 \pm$ & & \\
\hline & & júl. 4. & & $4(9)$ & & & 3,33 & & $0(4)$ & 0,67 (3) & $1,75 \pm$ & & \\
\hline & & aug. 15 . & & $0(2)$ & & & 7,50 & & - & - & - & & \\
\hline & & aug. 22 . & & $0(2)$ & & & 7,50 & & $5(4)$ & $0,33(3)$ & $2,50 \pm$ & & \\
\hline & & szept. 4. & & - & & & & & $0(2)$ & 0,00 (1) & $5,00 \pm$ & & \\
\hline & & okt. 3. & & - & & & & & - & - & - & & \\
\hline & & okt. 17. & & - & & & & & $0(1)$ & $1,00(1)$ & $6,00 \pm$ & & \\
\hline & & okt. 31. & & - & & & & & - & - & - & & \\
\hline & & $\begin{array}{l}\text { A látogato } \\
\text { A tartósar } \\
\text { A csalétke }\end{array}$ & felfe & śsalétke & & s7ó & az il & aj elsőként & $\begin{array}{l}\text { t jelen } \\
\text { meg. }\end{array}$ & & & & \\
\hline
\end{tabular}


9. táblázat. A gyakoribb fajok táplálkozási hatékonyságának páronkénti összehasonlítása a kétféle táplálékforráson a füredi tölgyesben. Az egyes cellákban a Mann-Whitney z értékek szerepelnek, a választóvonaltól balra lent a méz-méz, jobbra fent pedig a tonhal-tonhal összehasonlításban.

\begin{tabular}{lcccc}
\hline méz/tonhal & $\mathrm{ApSu}$ & $\mathrm{PrNi}$ & $\mathrm{Te}$ & $\mathrm{FoGa}$ \\
Aphaenogaster subterranea & - & $\mathbf{- 7 , 1 7} * * *$ & $\mathbf{- 1 0 , 2 4} * * *$ & $\mathbf{- 2 , 7 3} * *$ \\
Prenolepis nitens & $\mathbf{- 2 4 , 6 4} \mathbf{H}^{* * *}$ & - & $\mathbf{- 1 3 , 4 4} * * *$ & $-1,71 \mathrm{n} . \mathrm{sz}$. \\
Temnothorax spp. & $-1,25 \mathrm{n} . \mathrm{sz}$. & $\mathbf{- 9 , 1 7 * * *}$ & - & $\mathbf{- 6 , 6 0}$ *** \\
Formica gagates & $\mathbf{- 8 , 1 9} * * *$ & $\mathbf{- 3 , 7 1} * * *$ & $\mathbf{- 4 , 6 7 * * *}$ & - \\
\hline
\end{tabular}

n.sz. $0,05<\mathrm{p} ; * 0,01<\mathrm{p}<0,05 ; * * 0,001<\mathrm{p}<0,01 ; * * * \mathrm{p}<0,001$ 
10. táblázat. A gyakoribb fajok táplálkozási hatékonyságának páronkénti összehasonlítása a kétféle táplálékforráson a litéri fenyvesben. Az egyes cellákban a Mann-Whitney z értékek szerepelnek, a választóvonaltól balra lent a méz-méz, jobbra fent pedig a tonhal-tonhal összehasonlításban.

\begin{tabular}{lccccc}
\hline méz/tonhal & $\mathrm{ApSu}$ & $\mathrm{FoFu}$ & $\mathrm{Te}$ & $\mathrm{LaEm}$ & $\mathrm{FoGa}$ \\
Aphaenogaster subterranea & - & $\mathbf{- 5 , 8 9} * * *$ & $-1,34 \mathrm{n} . \mathrm{sz}$. & $\mathbf{- 3 , 0 5} * *$ & $\mathbf{- 3 , 8 4} * * *$ \\
Formica fusca & $\mathbf{- 1 8 , 0 3} * * *$ & - & $\mathbf{- 2 , 6 2} * *$ & $\mathbf{- 3 , 1 9} * *$ & $-0,78 \mathrm{n} . \mathrm{sz}$. \\
Temnothorax spp. & $\mathbf{- 7 , 4 5} * * *$ & $\mathbf{- 6 , 9 8} * * *$ & - & $-0,06 \mathrm{n} . \mathrm{sz}$. & $-1,39 \mathrm{n} . \mathrm{sz}$. \\
Lasius emarginatus & $\mathbf{- 8 , 0 3} * * *$ & $\mathbf{- 8 , 4 7} * * *$ & $-0,74 \mathrm{n} . \mathrm{sz}$. & - & $-1,85 \mathrm{n} . \mathrm{sz}$. \\
Formica gagates & $\mathbf{- 1 3 , 2 1} * * *$ & $-1,071 \mathrm{n} . \mathrm{sz}$. & $\mathbf{- 4 , 6 4} * * *$ & $\mathbf{- 6 , 1 6}$ *** & - \\
\hline
\end{tabular}

n.sz. $0,05<\mathrm{p} ; * 0,01<\mathrm{p}<0,05 ; * * 0,001<\mathrm{p}<0,01 ; * * * \mathrm{p}<0,001$ 
11. táblázat. A füredi tölgyes csalétkeket látogató gyakoribb fajaira jellemző fontosabb változók összefoglalása.

\begin{tabular}{|c|c|c|c|c|c|c|c|c|c|c|}
\hline Fajok & $\overline{\mathrm{DI}}{ }^{\mathrm{I}}$ & $\mathrm{T}_{\max }{ }^{2}$ & $\mathrm{~T}_{\max -\min }{ }^{3}$ & $\begin{array}{l}\text { látogatott } \\
\text { csalétkek }^{4}\end{array}$ & $\begin{array}{l}\text { elsőként } \\
\text { jelen }\end{array}$ & $\begin{array}{l}\text { elfoglalt } \\
\text { csalétkek }^{6}\end{array}$ & $\begin{array}{l}\text { elsőként } \\
\text { jelen }\end{array}$ & $\begin{array}{c}\text { felfedezési } \\
\text { idö }^{8}\end{array}$ & $\begin{array}{l}\text { tápl. hat. } \\
\text { (méz) }\end{array}$ & $\begin{array}{l}\text { tápl. hat. } \\
{\text { (tonhal })^{10}}\end{array}$ \\
\hline Aphaenogaster subterranea & 0,85 & 23,0 & 24,7 & 0,37 & 0,55 & 0,27 & 0,60 & 2,55 & 0,52 & 0,55 \\
\hline Prenolepis nitens & 0,72 & 18,3 & 23,2 & 0,62 & 0,84 & 0,51 & 0,87 & 2,56 & 0,82 & 0,62 \\
\hline Formica gagates & 0,18 & 24,8 & 24,8 & 0,20 & 0,15 & 0,06 & 0,19 & 4,84 & 0,75 & 0,60 \\
\hline Temnothorax spp. & 0,00 & 28,4 & 24,7 & 0,47 & 0,11 & 0,29 & 0,08 & 5,67 & 0,52 & 0,31 \\
\hline
\end{tabular}

${ }^{1}$ Dominancia index: azon interakciók gyakorisága, melyekböl az illető faj „győztesként” került ki (tkp. a kizárások és az összes kizárással/meneküléssel járó interakció hányadosa).

${ }^{2} \mathrm{~A}$ maximális aktivitásnál (legtöbb elfoglalt csalétek) mért átlaghömérséklet $\left({ }^{\circ} \mathrm{C}\right)$.

${ }^{3} \mathrm{~A}$ legmagasabb és legalacsonyabb hömérséklet különbsége $\left({ }^{\circ} \mathrm{C}\right)$, amelyen az illetö faj aktív volt.

${ }^{4} \mathrm{~A}$ látogatott csalétkek (amelyeken az illető faj megjelent) és az összes csalétek (max. 30/nap) hányada.

${ }^{5} \mathrm{~A}$ látogatott csalétkek azon hányada, ahol az illető faj elsőként jelent meg.

${ }^{6} \mathrm{~A}$ tartósan elfoglalt csalétkek (amelyeken az illető faj legalább az észlelések harmadában megfigyelhető volt) és az összes csalétek hányada.

${ }^{7}$ A tartósan elfoglalt csalétkek azon hányada, ahol az illető faj elsőként jelent meg.

${ }^{8}$ A csalétkek felfedezési (tkp. az illető faj adott csalétken való első, órában kifejezett észlelési) idejének átlaga.

${ }^{9}$ Táplálkozási hatékonyság (méz): a táplálkozó egyedek és az összes egyed hányadosának átlaga.

${ }^{10}$ Táplálkozási hatékonyság (tonhal): a táplálkozó egyedek és az összes egyed hányadosának átlaga. 
12. táblázat. A litéri fenyves csalétkeket látogató gyakoribb fajaira jellemző fontosabb változók összefoglalása.

\begin{tabular}{|c|c|c|c|c|c|c|c|c|c|c|}
\hline Fajok & $\mathrm{DI}^{1}$ & $\mathrm{~T}_{\max }{ }^{2}$ & $\mathrm{~T}_{\text {max }-\min }{ }^{3}$ & $\begin{array}{l}\text { látogatott } \\
\text { csalétkek }^{4}\end{array}$ & $\begin{array}{l}\text { elsőként } \\
\text { jelen }\end{array}$ & $\begin{array}{c}\text { elfoglalt } \\
\text { csalétkek }^{6}\end{array}$ & $\begin{array}{l}\text { elsőként } \\
\text { jelen }\end{array}$ & $\begin{array}{l}\text { felfedezési } \\
\text { idö }^{8}\end{array}$ & $\begin{array}{l}\text { tápl. hat. } \\
\text { (méz) }\end{array}$ & $\begin{array}{l}\text { tápl. hat. } \\
\text { (tonhal }^{10}\end{array}$ \\
\hline Lasius emarginatus & 1,00 & 26,1 & 22,4 & 0,19 & 0,44 & 0,13 & 0,56 & 4,04 & 0,67 & 0,58 \\
\hline Aphaenogaster subterranea & 0,90 & 23,0 & 22,8 & 0,30 & 0,57 & 0,20 & 0,62 & 3,38 & 0,46 & 0,52 \\
\hline Formica gagates & 0,57 & 20,5 & 22,2 & 0,13 & 0,39 & 0,08 & 0,41 & 3,22 & 0,85 & 0,62 \\
\hline Formica fusca & 0,09 & 27,4 & 22,4 & 0,65 & 0,45 & 0,43 & 0,52 & 4,45 & 0,80 & 0,60 \\
\hline Temnothorax spp. & 0,06 & 20,5 & 23,9 & 0,42 & 0,20 & 0,20 & 0,31 & 5,71 & 0,64 & 0,52 \\
\hline
\end{tabular}

${ }^{1}$ Dominancia index: azon interakciók gyakorisága, melyekből az illető faj „győztesként” került ki (tkp. a kizárások és az összes kizárással/meneküléssel járó interakció hányadosa).

${ }^{2}$ A maximális aktivitásnál (legtöbb elfoglalt csalétek) mért átlaghőmérséklet $\left({ }^{\circ} \mathrm{C}\right)$.

${ }^{3}$ A legmagasabb és legalacsonyabb hömérséklet különbsége $\left({ }^{\circ} \mathrm{C}\right)$, amelyen az illető faj aktív volt.

${ }^{4}$ A látogatott csalétkek (amelyeken az illető faj megjelent) és az összes csalétek (max. 30/nap) hányada.

${ }^{5}$ A látogatott csalétkek azon hányada, ahol az illető faj elsőként jelent meg.

${ }^{6}$ A tartósan elfoglalt csalétkek (amelyeken az illető faj legalább az észlelések harmadában megfigyelhető volt) és az összes csalétek hányada.

${ }^{7}$ A tartósan elfoglalt csalétkek azon hányada, ahol az illető faj elsőként jelent meg.

${ }^{8}$ A csalétkek felfedezési (tkp. az illető faj adott csalétken való első, órában kifejezett észlelési) idejének átlaga.

${ }^{9}$ Táplálkozási hatékonyság (méz): a táplálkozó egyedek és az összes egyed hányadosának átlaga.

${ }^{10}$ Táplálkozási hatékonyság (tonhal): a táplálkozó egyedek és az összes egyed hányadosának átlaga. 
13. táblázat. A lineáris korrelációs koefficiens (r) értékei a dominancia index (DI) és a Függelék 11-12. táblázatokban szereplő többi változó között a két vizsgálati élőhelyen.

\begin{tabular}{lcc}
\hline & $\begin{array}{c}\text { Füredi } \\
\text { tölgyes }\end{array}$ & $\begin{array}{c}\text { Litéri } \\
\text { fenyves }\end{array}$ \\
DI-T $_{\max }$ & $-0,80$ & 0,11 \\
DI-T $_{\text {max-min }}$ & $-0,47$ & $-0,46$ \\
DI-látogatott csalétkek $_{\text {DI-elsőként jelen }}$ & 0,32 & $-0,74$ \\
DI-elfoglalt csalétkek & 0,88 & 0,65 \\
DI-elsőként jelen & 0,50 & $-0,59$ \\
DI-felfedezési idő & 0,91 & 0,68 \\
DI-tápl. hat. (méz) & $-0,99 * *$ & $-0,70$ \\
DI-tápl. hat. (tonhal) & 0,13 & $-0,42$ \\
\hline n.sz. $0,05<\mathrm{p} ; * 0,01<\mathrm{p}<0,05 ; * * 0,001<\mathrm{p}<0,01 ; * * * \mathrm{p}<0,001$
\end{tabular}


14. táblázat. A dominancia rangsorrendjének linearitása a füredi tölgyesben.

\begin{tabular}{|c|c|c|c|c|c|c|c|c|}
\hline domináns/szubordinált & $\mathrm{CrSm}$ & $\mathrm{ApSu}$ & $\mathrm{PrNi}$ & LiMi & $\mathrm{LaBr}$ & $\mathrm{CaTr}$ & FoGa & $\mathrm{Te}$ \\
\hline Crematogaster schmidti & - & 1 & & & & & & 1 \\
\hline Aphaenogaster subterranea & 0 & - & + & & 1 & & 1 & 1 \\
\hline Prenolepis nitens & & + & - & & & 1 & 1 & 1 \\
\hline Liometopum microcephalum & & & & - & & & & 1 \\
\hline Lasius brunneus & & 0 & & & - & & 1 & \\
\hline Camponotus truncatus & & & 0 & & & - & & \\
\hline Formica gagates & & 0 & 0 & & 0 & & - & 1 \\
\hline Temnothorax spp. & 0 & 0 & 0 & 0 & & & 0 & - \\
\hline
\end{tabular}

1: a sorokban szereplö fajok dominanciája az oszlopokban szereplök felett. 0 : az oszlopokban szereplő fajok dominanciája a sorokban szereplők felett. +: kiegyenlített dominancia viszony. üres cellák: nem ismert dominancia viszony. 
15. táblázat. A dominancia rangsorrendjének linearitása a litéri fenyvesben.

\begin{tabular}{lcccccccc}
\hline domináns/szubordinált & $\mathrm{CaLi}$ & $\mathrm{LaEm}$ & $\mathrm{FoGa}$ & $\mathrm{ApSu}$ & $\mathrm{MySa}$ & $\mathrm{FoFu}$ & $\mathrm{CaFa}$ & $\mathrm{Te}$ \\
$\begin{array}{l}\text { Camponotus ligniperdus } \\
\text { Lasius emarginatus }\end{array}$ & - & & 1 & 1 & & 1 & & 1 \\
$\begin{array}{l}\text { Formica gagates } \\
\text { Aphaenogaster subterranea }\end{array}$ & 0 & - & 1 & & & 1 & 1 & \\
$\begin{array}{l}\text { Myrmica sabuleti } \\
\text { Formica fusca }\end{array}$ & 0 & & - & 1 & + & 1 & & \\
$\begin{array}{l}\text { Camponotus fallax } \\
\text { Temnothorax spp. }\end{array}$ & 0 & 0 & 0 & - & 1 & 1 & & 1 \\
\hline
\end{tabular}

1: a sorokban szereplő fajok dominanciája az oszlopokban szereplők felett. 0: az oszlopokban szereplő fajok dominanciája a sorokban szereplők felett. +: kiegyenlített dominancia viszony. üres cellák: nem ismert dominancia viszony. 


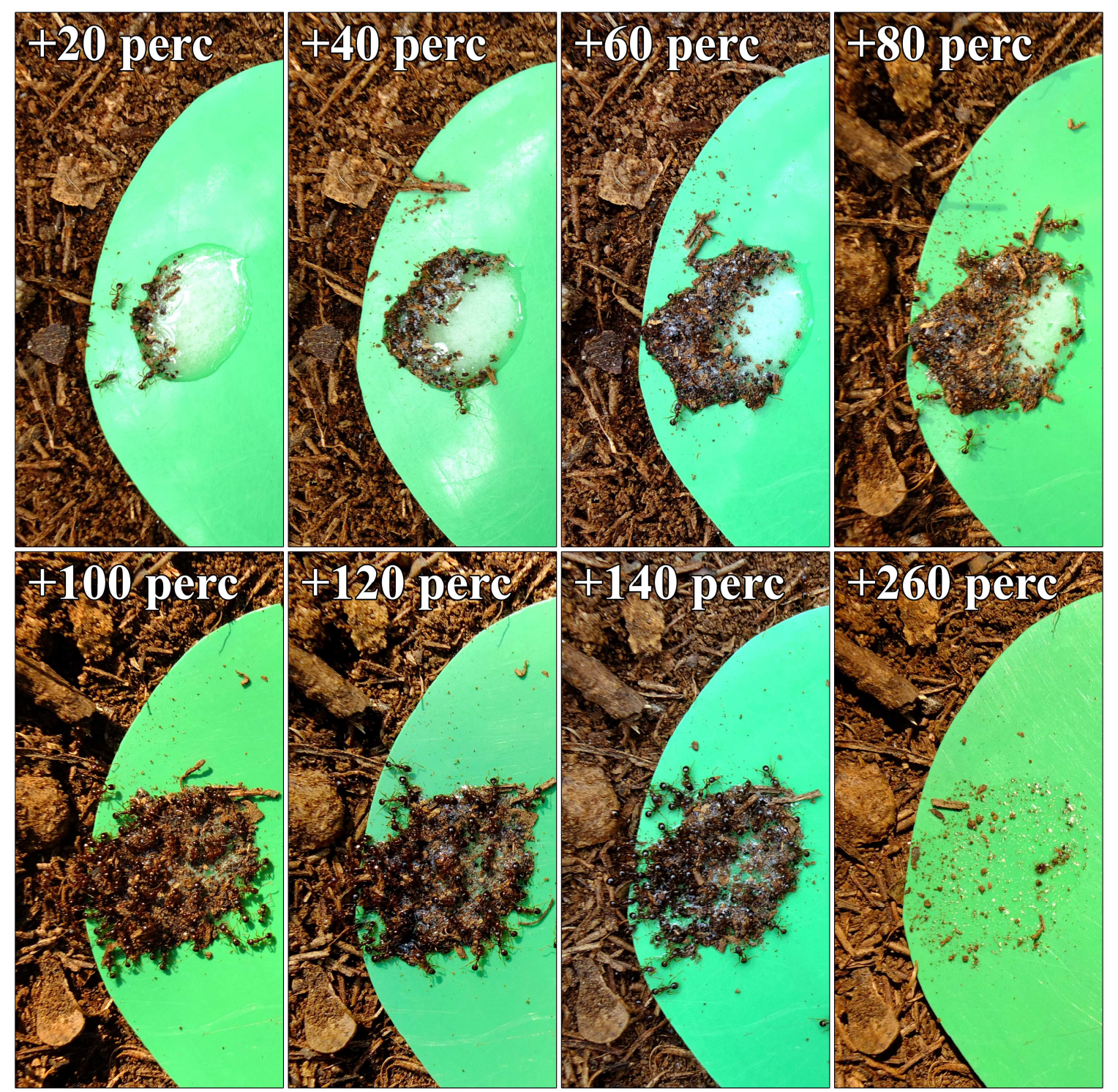

2. ábra. Az eszközhasználat hatékonysága a vizsgált Aphaenogaster subterranea kolóniák egyikénél. A megadott időegységek a dolgozók csalétken való első regisztrációját megelőző megfigyelés után eltelt perceket jelölik. 


\section{A dolgozat témaköréből készült publikációk jegyzéke}

Tudományos közlemények:

Lőrinczi G. (2014): Some notes on the tool-using behaviour of the ant, Aphaenogaster subterranea (Hymenoptera: Formicidae). Tiscia 40, 17-24.

Lőrinczi G. (2012): A novel association between Aphaenogaster subterranea (Hymenoptera: Formicidae) and the nymphs of Reptalus panzeri (Hemiptera: Cixiidae). European Journal of Entomology 109(4), 509-515.

Lőrinczi G. (2011): Density and spatial pattern of nests in sub-Mediterranean grounddwelling ant communities (Hymenoptera: Formicidae). Community Ecology 12(1), 51-57.

Lőrinczi G. (2009): Hangyafészkek denzitása és términtázata két szubmediterrán élőhelyen. In: Gallé L. (ed.): Entomológia: kutatás, szemléletformálás, ismeretterjesztés. Szeged, pp. 155-163.

Lőrinczi G. (2008): Hangyaközösségek (Hymenoptera: Formicidae) fajösszetétele és diverzitása Litér környéki szubmediterrán élöhelyeken. Folia Musei Historico-Naturalis Bakonyiensis - A Bakonyi Természettudományi Múzeum közleményei 25, 89-99.

Előkészületben:

Lőrinczi G.: Winter activity of the European false honeypot ant, Prenolepis nitens (Mayr, 1853) (Hymenoptera: Formicidae) in Hungary.

Lőrinczi G.: Spatio-temporal patterns in the structuring of ground-dwelling ant communities in sub-Mediterranean woodland habitats. 
Előadások és poszterek megjelent kivonatokkal:

Lőrinczi G. (2013): Winter activity of the false honeypot ant, Prenolepis nitens (Mayr, 1853) in Hungary. In: 5th Central European Workshop of Myrmecology - Abstracts. Innsbruck, Ausztria, 2013. szeptember 5-8., p. 87.

Lőrinczi G. (2012): Két szimpatrikus erdei hangyafaj, az Aphaenogaster subterranea és a Prenolepis nitens (Hymenoptera: Formicidae) táplálékszerzésének tér-idő mintázata. In: 9. Magyar Ökológus Kongresszus - Kivonatok. Keszthely, Magyarország, 2012. szeptember 5-7., p. 67.

Lőrinczi G. (2012): Association of Aphaenogaster subterranea (Hymenoptera: Formicidae) with the nymphs of Reptalus panzeri (Hemiptera: Cixiidae). In: 5th Congress of the European Sections of the IUSSI - Abstracts. Montecatini Terme, Olaszország, 2012. augusztus 26-30., p. 91.

Lőrinczi G. (2012): Egy recéskabóca faj, a Reptalus panzeri (Hemiptera: Cixiidae) nimfáinak asszociációja Aphaenogaster subterraneával (Hymenoptera: Formicidae). In: 4. Kárpátmedencei Mürmekológiai Szimpózium - Kivonatok. Kisnamény, Magyarország, 2012. július 30.-augusztus 4., p. 10.

Lőrinczi G. (2011): Seasonal structuring of sub-Mediterranean ground-dwelling ant communities. In: 4th Central European Workshop of Myrmecology - Abstracts. Kolozsvár, Románia, 2011. szeptember 15-19., p. 8.

Lőrinczi G. (2010): Hangyafészkek denzitásának és términtázatának időbeli változása. In: 3. Kárpát-medencei Mürmekológus Szimpózium - Kivonatok. Szenéte, Románia, 2010. szeptember 1-5., p. 10.

Lőrinczi G. (2009): Structure and organization of ant communities in two sub-Mediterranean habitats. In: 3rd Central European Workshop of Myrmecology - Abstracts. Fraueninsel Chiemsee, Németország, 2009. október 8-10., p. 42. 
Lőrinczi G. (2009): Hangyakolóniák términtázatának elemzése két szubmediterrán erdei élőhelyen. In: 8. Magyar Ökológus Kongresszus - Kivonatok. Szeged, Magyarország, 2009. augusztus 26-28., p. 136.

Lőrinczi G. (2007): Ant assemblage composition and diversity in a set of sub-Mediterranean habitats. In: 2nd Central European Workshop of Myrmecology - Abstracts. Szeged, Magyarország, 2007. május 17-19., p. 34.

Lőrinczi G. (2007): Hangyakolóniák términtázatának elemzése szubmediterrán gyepen és erdőben. In: 3. Szünzoológiai Szimpózium - Kivonatok. Budapest, Magyarország, 2007. március 5-6., p. 35.

Lőrinczi G. (2006): A kompetíció szerepe a hangyaközösségek szerveződésében. In: 7. Magyar Ökológus Kongresszus - Kivonatok. Budapest, Magyarország, 2006. szeptember 4-6., p. 135.

Lőrinczi G. (2004): Szubmediterrán hangyaközösségek szerveződése. In: 1. Kárpát-medencei Mürmekológiai Szimpózium - Kivonatok. Szeged, Magyarország, 2004. október 26., p. 7. 


\section{Egyéb publikációk jegyzéke}

Tudományos közlemények:

Gallé L., Kanizsai O., Maák I., Lőrinczi G. (2014): Close nesting association of two ant species in artificial shelters: Results from a long-term experiment. Acta Zoologica Academiae Scientiarum Hungaricae, megjelenés alatt.

Kanizsai O., Maák I., Lőrinczi G. (2014): The effect of laboratory colony condition on the trophallactic interactions of Camponotus vagus (Hymenoptera: Formicidae). Acta Zoologica Academiae Scientiarum Hungaricae, megjelenés alatt.

Maák I., Szántó A., Lőrinczi G. (2014): Waste management in the polymorphic ant Camponotus aethiops (Hymenoptera: Formicidae). Acta Scientiarum Transylvanica, megjelenés alatt.

Kanizsai O., Lőrinczi G., Gallé L. (2013): Nesting associations without interdependence: a preliminary review on plesiobiosis in ants. Psyche: A Journal of Entomology Vol. 2013 (Annual Issue on Ants and Their Parasites), pp. 1-9.

Gallé R., Lőrinczi G., Szpisjak N., Maák I., Torma A. (2012): Data on the arthropod (Araneae, Formicidae, Heteroptera) fauna of floodplain forests at the lower reach of the river Maros/Mureş. In: Körmöczi, L. (ed.): Landscape-scale connections between the land use, habitat quality and ecosystem goods and services in the Mureş/Maros valley. Tiscia Monograph Series 10, 45-66.

Lőrinczi G. (2011): Lasius nitidigaster Seifert, 1996 - a new ant species (Hymenoptera: Formicidae) for the Hungarian fauna. Natura Somogyiensis 19, 223-226.

Lőrinczi G., Bozsó M., Duma I., Petrescu M., Gallé R., Torma A. (2011): Preliminary results on the invertebrate fauna (Araneae, Orthoptera, Heteroptera and Hymenoptera: Formicidae) of alkaline grasslands of the Hungarian-Romanian border. In: Körmöczi, L. (ed.): Ecological and socio-economic relations in the valleys of river Körös/Criş and river Maros/Mureş. Tiscia Monograph Series 9, 159-173. 
Előkészületben:

Maák I., Torma A., Kovács J., Somogyi Á. A., Lőrinczi G.: Differences in the information transmitted through corpses to Formica sanguinea and Polyergus rufescens (Hymenoptera: Formicidae).

Somogyi Á. A., Lőrinczi G., Kovács J., Maák I.: Changes in ant assemblages during the succession of planted poplar (Populus alba) forests.

Előadások és poszterek megjelent kivonatokkal:

Somogyi Á. A., Maák I., Lőrinczi G., Kovács J. (2013): Successional changes of ant communities in planted poplar forests. In: 5th Central European Workshop of Myrmecology Abstracts. Innsbruck, Ausztria, 2013. szeptember 5-8., p. 103.

Szikora T., Erdős L., Lőrinczi G., Bozsó M. (2012): Gyepgazdálkodás hatása délkelet-alföldi szikes gyepek egyenesszárnyú közösségeire. In: 9. Magyar Ökológus Kongresszus Kivonatok. Keszthely, Magyarország, 2012. szeptember 5-7., p. 98.

Szalárdy O., Lőrinczi G., Gallé R., Gallé L. (2009): Hangyaközösségek szerkezete három Tisza-menti tájablakban. In: 8. Magyar Ökológus Kongresszus - Kivonatok. Szeged, Magyarország, 2009. augusztus 26-28., p. 206. 